ERDÉLYI TUDOMÁNYOS FÜZETEK

276

\author{
GIDÓ ATTILA
}

\title{
OKTATÁSI INTÉZMÉNYRENDSZER ÉS DIÁKPOPULÁCIÓ ERDÉLYBEN 1918-1948 KÖZÖTT
}

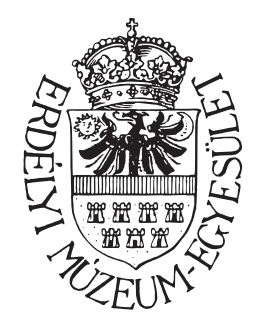

Kolozsvár, 2013 
A kötet megjelenését a Communitas Alapítvány, a Bethlen Gábor Alap és a Magyar Tudományos Akadémia támogatta.
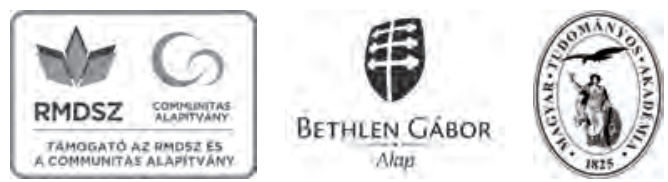

(C) Gidó Attila

(C) Erdélyi Múzeum-Egyesület, 2013

\section{Felelős kiadó}

BIRÓ ANNAMÁRIA

\section{Korrektúra}

ANDRÁS ZSELYKE

Müszaki szerkesztés, borítóterv

BODÓ ZALÁN

\section{Nyomdai munkálatok}

GLORIA, Kolozsvár

Felelős vezető

NAGY PÉTER

Descrierea CIP a Bibliotecii Naționale a României

\section{GIDÓ, ATTILA}

Oktatási intézményrendszerés diákpopuláció Erdélyben:1918-1948

között / Gidó Attila. - Cluj-Napoca : Societatea Muzeului Ardelean, 2013

Bibliogr.

ISBN 978-606-8178-75-2

37(498.4)"1918/1948" 


\section{TARTALOM}

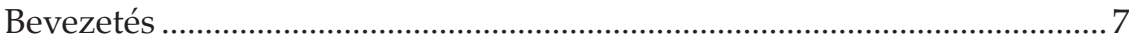

1. Etnikai és társadalmi viszonyok ..............................................................

1.1. Az erdélyi népesség etnikai és vallási megoszlása...........................9

1.2. Iskolázottsági szint....................................................................... 14

2. Az erdélyi/romániai oktatási rendszer jogi háttere és szerkezete ...........19

2.1. Az oktatásügy 1918-1940 között..................................................... 21

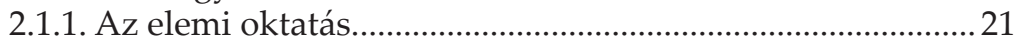

2.1.2. A középiskolai oktatás ............................................................. 26

2.1.3. Az egyházi, egyesületi és magániskolák helyzete ................29

2.1.4. A felsőoktatás .............................................................................. 31

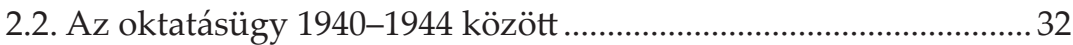

2.3. Az oktatásügy 1944-1948 között .........................................................3

3. Az erdélyi tanintézmények 1918-1940 között.............................................35

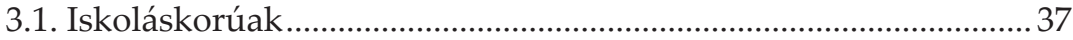

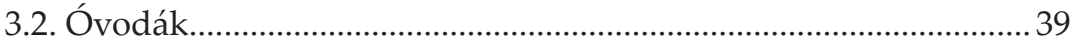

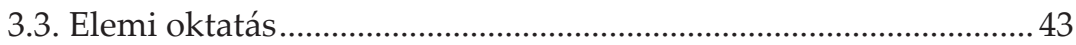

3.4. Középfokú oktatás ........................................................................... 51

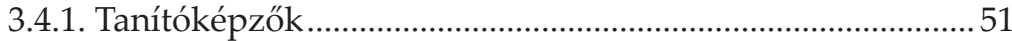

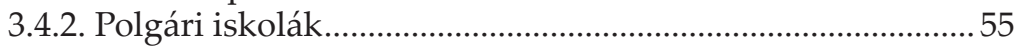

3.4.3. Gimnáziumok és alsó fokú leányiskolák ................................59

3.4.4. Líceumok és felső fokú leányiskolák ....................................... 66

3.4.5. Kereskedelmi iskolák .............................................................. 74

3.4.6. Ipariskolák, szakiskolák és háztartási iskolák........................ 84

4. Az erdélyi tanintézmények 1940-1948 között............................................. 95

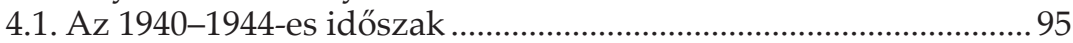

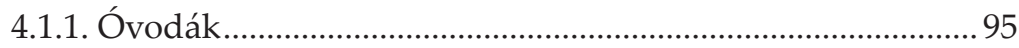

4.1.2. Elemi oktatás .......................................................................... 97 


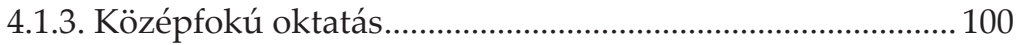

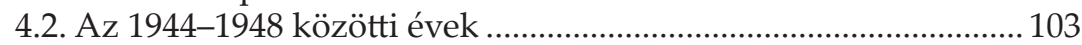

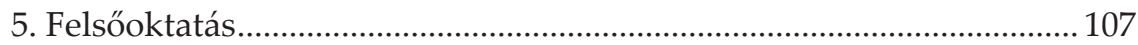

5.1. Elektromechanikai almérnöki iskola, Kolozsvár .......................... 108

5.2. Agrártudományi Akadémia, Kolozsvár......................................... 110

5.3. Felsőkereskedelmi és Ipari Akadémia, Kolozsvár-Brassó .......... 112

5.4. A kolozsvári Zene- és Színművészeti Akadémia, valamint a temesvári Szépmüvészeti Iskola................................... 116

5.5. Müszaki Főiskola (Politechnika), Temesvár .................................... 118

5.6. Jogi Akadémia, Nagyvárad............................................................ 120

5.7. Egyetemi fokú teológiai intézetek.................................................. 123

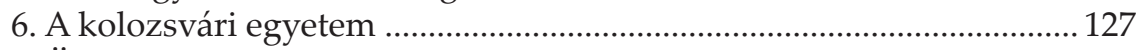

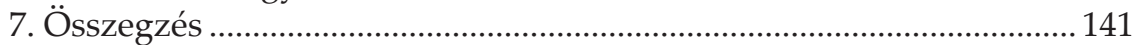

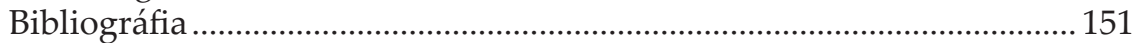

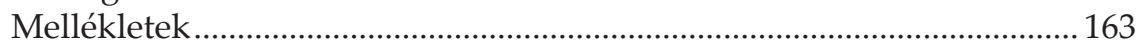

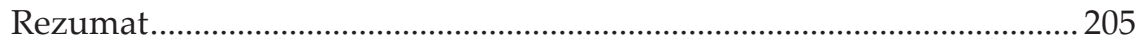

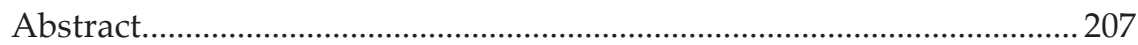




\section{BEVEZETÉS}

Az alábbi munka kizárólag az erdélyi oktatási rendszernek és a kultúratermelő intézményeknek az 1918-1948 közötti statisztikai bemutatására vállalkozik. Mindezt elsősorban az eddig publikált statisztikai összesítések, népszámlálások, évkönyvek, szaktanulmányok felhasználásával teszi meg, anélkül, hogy levéltári alapkutatásokra és mély elemzésekre vállalkozna. ${ }^{1} \mathrm{~A}$ tanulmány egy nagyobb európai összehasonlító kutatás első fázisába illeszkedik bele. ${ }^{2}$ A második fázis mélyelemzéseihez szükséges dokumentáció összeállítását a kutatás további munkatársai végzik, és eredményeik remélhetőleg a közeljövőben napvilágot látnak.

Az 1918-at követő erdélyi oktatásügy helyzete, a nemzeti kisebbségek iskolaproblémái és kulturális jogai nemcsak tudományos viták, nézeteltérések tárgyát képezték, hanem a politikum szintjén is megjelentek. Ez elsősorban az erdélyi/romániai magyarság által elszenvedett iskolaügyi sérelmeknek és a korabeli román állam ezt tagadó álláspontjának az ütközéséből fakadt. Tisztában vagyunk a kérdés súlyával és volumenével, a tanulmányunk mégsem kíván foglalkozni ezekkel a vitákkal és a kisebbsé-

\footnotetext{
${ }^{1}$ Jelen tanulmány a kolozsvári Nemzeti Kisebbségkutató Intézet kiadójánál megjelent angol nyelvű szöveg javított és bővített magyar változata: Gidó Attila: School Market and the Educational Institutions in Transylvania, Partium and Banat between 1919 and 1948. Working Paper, nr. 39, Institutul pentru Studierea Problemelor Minorităților Naționale, Cluj-Napoca, 2011. (http:// www.ispmn.gov.ro/node/school-market-and-the-educational-institutions-in-transylvaniapartium-and-banat-between-1919-and-1948). Elkészítését az Etnikailag és vallásilag összetett elitek Kelet-Közép-Európában (1900-1950) (Erdély, Észtország, Lettország, Magyarország, Szlovákia, Vajdaság c. FP7-es projekt és a Nemzeti Kisebbségkutató Intézet támogatta.

${ }^{2}$ A kutatás címe: Etnikailag és vallásilag összetett elitek Kelet-Közép-Európában (1900-1950) (Erdély, Észtország, Lettország, Magyarország, Szlovákia, Vajdaság). Vezetője: Karády Viktor.
} 
gek sérelmeivel, csupán utal rájuk. ${ }^{3}$ Teszi mindezt azért, mert a sérelmeknek vagy általában a kisebbségi oktatásnak a vizsgálata külön kutatást és önálló kiadványt igényel. Ez a könyv elsősorban általános adatokkal kíván szolgálni, abban a reményben, hogy a témával foglalkozó kutatók számára kiváló kiindulási alapot nyújthat akár egy kisebbségi oktatásról és sérelmekről szóló kézirat elkészítéséhez is.

Az elsődleges célunk az volt, hogy egy olyan, etnikai és felekezeti bontást is tartalmazó oktatásstatisztikai munkát állítsunk össze, amely egyaránt kiindulópont lehet a korszakkal foglalkozó történészek, szociológusok, statisztikusok számára és az egyetemi oktatásban is haszonnal forgathatják az érdeklődők. Mindazonáltal, a száraz adatsorok mellett, igyekeztünk rámutatni azokra a főbb irányvonalakra, amelyek jellemezték az 1918-1948 közötti időszak oktatási piacát, a mindenkori hatalom oktatáspolitikáját, és az etnikum/felekezetspecifikus sajátságokra is utaltunk.

Az összefoglaló első felében, a társadalomszerkezet és a jogi szabályozások időbeni változásának bemutatását követően, az erdélyi oktatási intézmények és a diákpopuláció statisztikai adatai kerülnek ismertetésre. Mielőtt rátérnénk a témára, szükségesnek tartjuk röviden vázolni a korabeli Erdély etnikai és foglalkozási viszonyait.

${ }^{3}$ A vitákra, sérelmekre lásd: Balázs 1929, Rónai 1934, Mikó 1941, Nagy 1944, Balogh 1996, Bíró 2002, Bárdi 2004, Transilvania, Banatul, Crişana, Maramureşul 1929, Caliani 1934, Drăgoescu 1999: 890-893. és 1016-1226. 


\section{ETNIKAI ÉS TÁRSADALMI VISZONYOK}

\subsection{Az erdélyi népesség etnikai és vallási megoszlása}

Erdély oktatási intézményhálózatának és kulturális intézményeinek múködését, szellemi hátterét jelentős mértékben meghatározta a terület etnikai sokszínűsége. Vizsgálatunk kezdete, 1918, korszakhatárt jelent a régió történetében. Az első világháborút a vesztesek oldalán befejező Magyarország 1918 őszén fokozatosan visszavonult a magyarok, románok, németek, zsidók, ukránok és szerbek által vegyesen lakott keleti és északkeleti területeiről. A ma már együttesen Erdélyként emlegetett, 1918-ban elvesztett kelet-magyarországi területek lényegében három, etnikai összetételük, gazdasági fejlettségük, kulturális intézményhálójuk, urbanizációs szintjük szempontjából sok esetben eltérő jellegzetességekkel bíró régiót foglalnak magukban: történelmi Erdély, Bánság és Partium. A tanulmányunkban Erdély alatt tehát e három régió összességét értjük. Csak abban az esetben használjuk a történelmi megnevezéseket, amikor az adatsoraink nem a teljes volt magyarországi területekre, hanem csak valamelyik régióra, tehát a történelmi Erdélyre, a Bánságra vagy a Partiumra vonatkoznak.

Erdélyre nézve 1930-ig nem rendelkezünk etnikai statisztikákkal. A magyar népszámlálások csak az anyanyelvre és a vallásra kérdeztek rá. Az 1930-as román népszámlálás viszont már nemzetiségi adatokat is közölt. A történelmi Erdély, a Bánság és a Partium területén 1910-ben 5247205 lakost írtak össze. Közülük 53,6\% (2 811719 fö) volt román anyanyelvü, 31,5\% (1 653 943) magyar, 10,7\% (562 079) német, 1\% (50 370) szerb és 0,6\% (31 034) szlovák (Varga 1998: 364-373). 
Tekintettel arra, hogy vizsgálatunk időbeni keretei főként a két világháború közötti periódust érintik, az 1930-as etnikai és anyanyelvi adatokat részletesebben kívánjuk közölni. 1930-ra - 1910-hez képest - a terület lakossága több mint 300 000-rel gyarapodott. Ezzel együtt az etnikai arányokban is változások következtek be. 1930-ban 58,3\%, azaz 3233216 személy vallotta magát román anyanyelvünek, és valamivel kevesebben, 57,8\% (3 207 880) román nemzetiségúnek. A magyar anyanyelvű népesség aránya 26,7\%-ra (1 480712 ), a magyar nemzetiségúeké pedig 24,4\%-ra (1 353 276) csökkent. Őket arányukban a német anyanyelvúek követték 9,7\%-kal (540 793), illetve a német nemzetiségúek 543852 személlyel, amely 9,8\%-ot tett ki (Recensământ 1930, vol. 2: XXVIII-XXIX).

1. Erdély nemzetiségei 1930-ban:

\begin{tabular}{|l|c|c|}
\hline & Anyanyelv & Nemzetiség \\
\hline Román & 3233216 & 3207880 \\
\hline Magyar & 1480712 & 1353276 \\
\hline Német & 540793 & 543852 \\
\hline Zsidó/ Jiddis & 111275 & 178699 \\
\hline Cigány & 43653 & 109156 \\
\hline Ukrán, rutén & 24217 & 29607 \\
\hline Szerb, horvát, szlovén & 42359 & 43342 \\
\hline Cseh, szlovák & 40630 & 46786 \\
\hline Egyéb & 31508 & 35765 \\
\hline Összesen & 5548363 & 5548363 \\
\hline
\end{tabular}

2. Erdély nemzetiségei 1930-ban százalékos megoszlásban:

\begin{tabular}{|l|c|c|}
\hline & Anyanyelv & Nemzetiség \\
\hline Román & 58,3 & 57,8 \\
\hline Magyar & 26,7 & 24,4 \\
\hline Német & 9,7 & 9,8 \\
\hline Zsidó/Jiddis & 2,0 & 3,2 \\
\hline Cigány & 0,8 & 2,0 \\
\hline Ukrán, rutén & 0,4 & 0,5 \\
\hline Szerb, horvát, szlovén & 0,8 & 0,8 \\
\hline Cseh, szlovák & 0,7 & 0,8 \\
\hline Egyéb & 0,6 & 0,6 \\
\hline
\end{tabular}

1941-ben, a román és a magyar népszámlálások alkalmával, Észak- és Dél-Erdély területén összesen 5882600 főt regisztráltak. A román nemzetiségűek aránya 55,9\% (3 288 400), a magyaroké 29,5\% (1 735700$)$, a németeké 9,1\% (533 600) és a zsidóké 1,4\% (82 500) volt (Varga 1998: 364-373). 
Látható, hogy a zsidó etnikumúak száma jóval alatta maradt a zsidó/izraelita felekezetű személyekének. Ez főként annak tudható be, hogy az erdélyi zsidóság nagy része magyar kultúrájú és magyar vagy magyar-zsidó identitású volt. Az 1930-as román népszámlálás során erőteljes nyomás nehezedett az erdélyi zsidóságra abban a tekintetben, hogy ne magyarnak, hanem zsidó nemzetiségünek vallják magukat. Sok esetben a népszámlálást végző biztosok önkényesen döntöttek az izraelita felekezetü lakosok zsidó nemzetiségüként való regisztrálásáról. Ennek következtében az 1930-as népszámlálás 192373 izraelita vallásút és 178284 zsidó etnikumú személyt mutatott ki Erdély területén. Az 1941-es észak-erdélyi magyar népszámlálás esetén már sokkal kisebb arányban vallották magukat az izraeliták zsidó nemzetiségünek.

Ha az 1941-es észak- és dél-erdélyi adatokat külön vizsgáljuk, akkor az látható, hogy a Magyarországhoz visszakerült részeken a magyar lakosság volt számbeli fölényben. A 2590811 lakosból 1069242 fö (41,3\%) volt román anyanyelvü, és 1029493 (39,7\%) román nemzetiségü. Magyar anyanyelvünek 52,1\% (1 349 545), magyar nemzetiségünek pedig 53,5\% (1 386 670) deklarálta magát. A német anyanyelvűek többsége Dél-Erdélyben élt, így az 1941-es magyarországi népszámlálás csak 1,8\%-ot (47 556) mutatott ki. Azok, akik etnikailag is németeknek vallották magukat, még kevesebben voltak (1,7\%, azaz 44704 fó). A jiddis anyanyelvúek aránya 1,9\% (49 970) és a zsidó nemzetiségüeké is 1,9\%-ot (48 704) tett ki. Dél-Erdélyben jelentősen másképp néztek ki az etnikai viszonyok. Itt az 1941-ben regisztrált 3332898 lakosból 68,2\% (2 274 561) volt román nemzetiségü, 10,9\% (363 206) magyar, 14,7\% (490 640) német és 1,2\% (40 937) zsidó (Rotariu 2002: 121, 332-335, Gyémánt 2004: 127).

Erdély esetében a vallási megoszlás nagy vonalakban az etnikai határokat követte. A görögkeletiek és a görög katolikusok túlnyomó többsége román volt. A szerbek, ukránok és ruténok ugyancsak e két előbbi egyházhoz tartoztak. A római katolikusok és a protestáns egyházak hívei a kisebbségi magyar és német, valamint a bolgár, szlovák, cseh és horvát lakosság köréből kerültek ki. Az 1910-es népszámlálás adatai szerint Erdélyben a görögkeletiek aránya volt a legmagasabb 34,4\%-kal (1 806960 fő), őket pedig a görög katolikusok követték 23,7\%-kal (1 244 928). A római katolikusok 18,9\%-ot alkottak (994 748), a reformátusok 13,2-t (694 895), az evangélikusok 5-öt (262 383), az unitáriusok 1,3-at (68 752), az izraeliták pedig 3,5\%-ot (182 484) (Kepecs 2001: 20-21).

A korábbi tendenciáknak megfelelően 1930-ban a görögkeletiek és a görög katolikusok aránya együttesen közel 60\%-ot tett ki, őket követték a római katolikusok, a reformátusok, az evangélikusok és az izraeliták (Kepecs 2001: 22-23). 
3. Erdély vallási megoszlása 1930-ban:

\begin{tabular}{|l|c|c|}
\hline Görögkeleti & 1932356 & 34,8 \\
\hline Görög katolikus & 1385445 & 25,0 \\
\hline Római katolikus & 947351 & 17,1 \\
\hline Református & 696320 & 12,6 \\
\hline Evangélikus & 274415 & 4,9 \\
\hline Unitárius & 68330 & 1,2 \\
\hline Baptista & 37829 & 0,7 \\
\hline Izraelita & 192833 & 3,5 \\
\hline Egyéb & 13484 & 0,2 \\
\hline Összesen & 5548363 & $100 \%$ \\
\hline
\end{tabular}

Az 1940-ben Magyarországhoz visszakerült Észak-Erdélyben az 1941-es népszámlálás adatai szerint 37,2\% görög katolikus élt (960 329). A reformátusok aránya $22,9 \%$ volt (591 761), a római katolikusoké 20,8\% (536 204). A görögkeleti népesség többsége Dél-Erdélyben maradt, ennek tudható be, hogy a Magyarországhoz csatolt részeken alig 8,9 százalékot (228 804 fó) tettek ki. Az izraeliták aránya 5,9\% (151 312) volt, az unitáriusoké 1,9\% (49 193) és az evangélikusoké 1,7\% (44 313) (Kepecs 2001: 28-29).

Az oktatási intézményhálózat és a kulturális infrastruktúra szempontjából is fontos kitérni Erdély urbanizációs szintjére és az egyes etnikumok jellegzetességeire. 1920-ban a 40 erdélyi városban 721546 személy élt, amely a terület lakosságának 14,1\%-át jelentette. Tíz évvel később a városi lakosság aránya 17,2\%-ra, ${ }^{4}$ 1941-ben pedig 19,4\%-ra nőtt. Ez a növekedés nem csupán a népmozgásnak volt köszönhető, hanem újabb városi rangot kapott települések megjelenésének is. Az 1920-1941 közötti időszakban tízzel növekedett a városok száma Erdélyben (Varga 1998: 187). Amenynyiben egyes népcsoportok esetében vizsgáljuk a városiasodás mértékét, látható, hogy jelentős eltérések mutatkoznak meg ezen a területen. A pólus egyik végletét a zsidó lakosság képviseli, amely a falvakról városokba történő beköltözéseknek köszönhető́n a 20. századra jellegzetesen urbánus népességgé vált. 1910-ben 45,3\%-uk élt városon, 1930-ra viszont a zsidó népességen belüli városiak aránya meghaladta az 56\%-ot. Az 1941-es magyar népszámlálás szerint Észak-Erdélyben a zsidóság 57,6\%-a élt városon. Ezzel szemben a román népszámlálások adatai szerint a Romániánál maradt

\footnotetext{
${ }^{4}$ Ebben az évben, tehát 1930-ban, Romániának 20,2\%-a lakott városon és 79,8\%-a falun. A városi lakosság arányát tekintve Erdélyt a következő romániai régiók előzték meg: Munténia (27,1\%), Dobrudzsa (23,8\%), Moldova (24,3\%), Bukovina (26,6\%) (Scurtu 2003: 125).
} 
Dél-Erdélyben lakó zsidóknak már 80,2\%-a volt városi lakos 1941-ben. Mindez azt jelenti, hogy a második világháború alatt Észak- és Dél-Erdély zsidóságának összesen mintegy hatvankilenc százaléka élt városon (Sulyok-Fritz 1930: 112, Gyémánt 2004: 256). A holokauszt után tovább nőtt a városi zsidók aránya, hiszen a falvakról deportált és a holokausztot túlélő zsidóság többsége 1944 után városon telepedett le. 1947-ben a megmaradt zsidóság 85,1\%-a volt városi, 1956-ban pedig már több mint 90\% (Gyémánt 2004: 142-143).

Ami a régió két legnagyobb etnikumát - azaz a románokat és a magyarokat - illeti, jelentős változásoknak lehetünk tanúi 1918 után. 1910-ben Erdély városi lakosságának 55,6\%-át alkották a magyarok, 17,6\%-át a románok, 14,2\%-át a németek és 9,6\%-át a zsidók. Erdély Romániához történő csatolását követő első néhány évben jelentős magyar kivándorlás zajlott Magyarországra, amely főként a városi lakosságot érintette. Ezzel párhuzamosan felerősödött a román népesség városokra történő beköltözése, és megnőtt a városi rangú települések száma. Ilyen körülmények között 1930-ra jelentős arányeltolódásokat figyelhetünk meg: ekkor a városi lakosságnak már csak 37,9\%-át alkották a magyarok, a románok aránya pedig 35\%-ra nőtt. A németek esetében enyhe csökkenés $(13,2 \%)$, míg a zsidók esetében enyhe növekedés $(10,4 \%)$ volt tapasztalható. Mindez azt is jelentette, hogy a 20. század elején túlnyomóan rurális népességü erdélyi románságon belül erőteljes urbanizációs folyamat ment végbe. 1910-ben a román lakosságnak 5,4\%-a élt városon, 1930-ban már 10,5\%. A magyarokon belül a városi népesség aránya 1910-ben $28,9 \%$, a németeken belül pedig $21,7 \%$ volt. 1930-ra a magyarok esetében $27 \%$-ra csökkent ez az arány, a német lakosságon belüli városiak aránya viszont 23,3\%-ra nőtt (Livezeanu 1995: 135). Az első világháborút követő változások ellenére, a városi társadalmakat tehát továbbra is a magyarok, a németek és a zsidók dominálták, ők határozták meg a városok arculatát. Ennek következtében a két világháború közötti román nemzetépítés prioritásai közé tartozott a városok etnikai képének a megváltoztatása. Mindezt elsősorban a városi román állami hivatalnokrétegnek, az állami alkalmazottak számának a felduzzasztásával próbálták elérni (Kiss 2010: 17).

Az oktatási rendszer felvázolása előtt röviden utalni kell a régió népességének foglalkozási megoszlására is. 1930-ban Erdély össznépességének 69,7\%-a élt őstermelésből, 12,6\%-a bányászatból és iparból, 6,1\%-a kereskedelemből és hitelből. A közigazgatás és a hadsereg is a népesség 1,5-1,5\%-át foglalkoztatta. Az alkalmi munkások aránya 1,7, a közoktatásban dolgozóké 0,8 és a vallásfelekezetek szolgálatában állóké $0,6 \%$ volt. Mindez etnikai bontásban jóval összetettebb képet mutatott. A román lakosság körében volt ugyanis a legnagyobb az őstermelésből élők aránya 
(81\%), míg a magyarok és a németek esetében sokkal kiegyensúlyozottabb volt a foglalkozásszerkezet. A magyaroknak ötvennyolc százaléka, a németeknek pedig 54,1\%-a foglalkozott őstermeléssel. A korábbi tendenciáknak megfelelően a zsidó népesség körében továbbra is igen alacsony maradt az őstermelésből élők aránya (9,2\%), viszont több mint kétharmad részüknek a bányászatból és az iparból (26,7\%), valamint a kereskedelem, a hitel és a közlekedés (40,4\%) ágazataiból származott a jövedelme (Kiss 2010: 21).

Látható tehát, hogy Erdély összlakosságának többsége az agrárszektorban talált megélhetést, egyes etnikumok szintjén viszont igen differenciált volt a foglalkozásszerkezet. Ennek megfelelően a különböző foglalkozási szektorokban nemzetiségi arányeltolódásokat figyelhetünk meg. Mindez szoros összefüggésben állt a nemzetiségek körében tapasztalható modernizációs szinttel, illetve az írni-olvasni tudásnak és az iskolázottsági szintnek az alakulásával, az iskolaválasztással és a pályaorientációval.

\subsection{Iskolázottsági szint}

Erdély népességének iskolázottsági szintjét az 1910-es magyar és az 1930-as román népszámlálások alapján mutatjuk be.

1910-ben a 6 éven felüli erdélyi lakosság 51,1\%-a volt írástudó. Ha viszont csak a történelmi Erdély adatait vizsgáljuk, akkor ez az arány valamivel magasabb, 54\%. Mindez viszont jóval alatta maradt az összmagyarországi adatoknak. 1910-ben a 6 éven felüli magyarországi lakosságnak hatvanhét százaléka tudott írni-olvasni, amely az erdélyi területek népességének jelentős lemaradását jelzi (Karády-Nagy 2009: 12). 1930-ra lényeges pozitív változások történtek. Ekkor a közben Romániához került, 7 éven felüli erdélyi (történelmi Erdély, Bánság, Partium) lakosság 67,4\%-a volt írástudó, amely a legmagasabbnak bizonyult Nagy-Románia különböző régióihoz képest (Recensământ 1930, vol. 3: X-XI):

4. Az írástudók aránya Románia különböző régióiban:

\begin{tabular}{|l|c|c|}
\hline Írástudók & $\mathbf{1 8 9 7 - 1 9 1 0}$ & $\mathbf{1 9 3 0}$ \\
\hline Erdély & $51, \mathbf{1} \%(1910)$ & $67,4 \%$ \\
\hline Bukovina & $45,2 \%(1910)$ & $65,7 \%$ \\
\hline Ókirályság & $39,3 \%(1912)$ & $56,1 \%$ \\
\hline Cadrilater & $27,9 \%(1910)$ & $45,5 \%$ \\
\hline Besszarábia & $19,4 \%(1897)$ & $38,2 \%$ \\
\hline Átlagosan & - & $57,1 \%$ \\
\hline
\end{tabular}


Az írástudók aránya a falvak és a városok szintjén, valamint a kisebb régiók szerint is változott. A 7 évet betöltött lakosságot véve alapul, 1930-ban az írástudók legmagasabb aránya a történelmi Erdély városi népességének körében volt $(87,5 \%)$, a legalacsonyabb arány pedig a Partium rurális környezetében $(55,1 \%)$ (Recensământ 1930, vol. 3: XXVIII-XLIX).

5. Írástudók Erdélyben 1930-ban:

\begin{tabular}{|c|c|c|c|c|c|}
\hline & & $\begin{array}{l}\text { Történelmi } \\
\text { Erdély }\end{array}$ & Bánság & Partium & Összesen \\
\hline \multirow{3}{*}{ Városok } & $\begin{array}{l}7 \text { éven felüli } \\
\text { lakosság }\end{array}$ & 455411 & 151234 & 244965 & 851610 \\
\hline & \multirow{2}{*}{ Írástudók } & 401002 & 132261 & 210561 & 743824 \\
\hline & & 88,1 & 87,5 & 86,0 & 87,3 \\
\hline \multirow{3}{*}{ Falvak } & $\begin{array}{l}7 \text { éven felüli } \\
\text { lakosság }\end{array}$ & 2171979 & 663169 & 910147 & 3745295 \\
\hline & \multirow{2}{*}{ Írástudók } & 1397067 & 455219 & 501921 & 2354207 \\
\hline & & 64,3 & 68,6 & 55,1 & 62,9 \\
\hline \multirow{3}{*}{ Összesen } & $\begin{array}{l}7 \text { éven felüli } \\
\text { lakosság }\end{array}$ & 2627390 & 814403 & 1155112 & 4596905 \\
\hline & \multirow{2}{*}{ Írástudók } & 1798069 & 587480 & 712482 & 3098031 \\
\hline & & 68,4 & 72,1 & 61,7 & 67,4 \\
\hline
\end{tabular}

A 7 éven felüli írástudók nemi megoszlása a következőképpen alakult 1930-ban (Recensământ 1930, vol. 3: XXVIII):

6. A 7 éven felüli írástudók nemi megoszlása Erdélyben:

\begin{tabular}{|l|c|c|c|c|c|}
\hline \multirow{2}{*}{} & \multicolumn{5}{|c|}{ Falvak és városok összesen } \\
\cline { 2 - 6 } & \multicolumn{2}{|c|}{ Férfi } & \multicolumn{2}{c|}{ Nő } & Összesen \\
\hline Történelmi Erdély & 962435 & 53,5 & 835634 & 46,5 & 1798069 \\
\hline Bánság & 317214 & 54,0 & 270266 & 46,0 & 587480 \\
\hline Partium & 384651 & 54,0 & 327831 & 46,0 & 712482 \\
\hline Összesen & 1664300 & 53,7 & 1433731 & 46,3 & 3098031 \\
\hline
\end{tabular}


Az 1930-as népszámlálás szerint az írni és olvasni tudó, 7 éven felüli erdélyi lakosságnak 85,6\%-a rendelkezett elemi szintű képzéssel. Középiskolai végzettsége 9,2\%-nak volt, egyetemi és főiskolai képzettsége pedig összesen 1,4\%-nak (Recensământ 1930, vol. 3: XXVIII).

7. A 7 éven felüli írástudó személyek iskolázottsági szintje 1930-ban.

\begin{tabular}{|l|c|c|c|c|}
\hline \multirow{2}{*}{$\begin{array}{c}\text { Történelmi } \\
\text { Erdély }\end{array}$} & Bánság & Partium & Összesen \\
\hline \multirow{2}{*}{ vagy ismemín kívtlen oktatás } & 16329 & 5439 & 8415 & 30183 \\
\cline { 2 - 5 } & 0,9 & 0,9 & 1,2 & 1,0 \\
\hline \multirow{2}{*}{ Középfokú oktatás } & 1542028 & 508006 & 601138 & 2651172 \\
\cline { 2 - 5 } & 85,8 & 86,5 & 84,4 & 85,6 \\
\hline \multirow{2}{*}{ Szakoktatás } & 162663 & 53099 & 70531 & 286293 \\
\cline { 2 - 5 } & 9,0 & 9,0 & 9,9 & 9,2 \\
\hline \multirow{2}{*}{ Egyetemi oktatás } & 40400 & 11457 & 17650 & 69507 \\
\hline \multirow{2}{*}{ Egyéb felsőfokú oktatás } & 2,2 & 2,0 & 2,5 & 2,2 \\
\cline { 2 - 5 } & 18780 & 4244 & 6423 & 29447 \\
\hline \multirow{2}{*}{ Összesen } & 1,0 & 0,7 & 0,9 & 1,0 \\
\hline & 1746 & 2380 & 2394 & 13120 \\
\hline
\end{tabular}

1910-ből csupán a történelmi Erdélyre vonatkozóan rendelkezünk pontos adatokkal. Mivel a magyar népszámlálás a nemzetiségi hovatartozásra nem kérdezett rá, ezért 1910-ből a vallási adatokkal foglalkozunk. Korábbi kutatásokból ismert jelenség az erdélyi/magyarországi zsidóság túliskolázottsága az egyéb felekezetekhez/etnikumokhoz képest (Karády 1997: 79). 1910-ben például a történelmi Erdély területén az önálló törvényhatósági jogú városokban (Kolozsvár, Marosvásárhely) lakó, 20-24 év közötti zsidó férfiaknak 3,5 százaléka volt írástudatlan, 12,4 százalékuk rendelkezett 4 osztályos iskolával, 28,4\% pedig 8 osztállyal. A 20-24 éves zsidó nők körében az írástudatlanok aránya 2,7\% volt, a 8 osztályt végzetteké pedig 2,3. Ezzel szemben a városon élő 20-24 éves görög katolikus férfi lakosságnak 44,4\%-a nem tudott írni-olvasni, 1,1\%-uk 4 osztályt, 2,8\%-uk 8 osztályt végzett. A hasonló korú görög katolikus nők 56,3\%-a volt írástudatlan, és 0,5\%-uk rendelkezett 8 osztállyal. A zsidó és görög katolikus lakosságra vonatkozó értékek között helyezkednek el a többi felekezetre vonatkozó adatok: A római katolikus vallású, urbánus területen élő 20-24 éves férfi- 
ak körében 6,5\%-os, a reformátusok körében 7,2, a görögkeletiek esetében 39,2\%-os volt az írástudatlanság (Karády 2009: 278-301).

Amennyiben megyei szinten vizsgáljuk meg az illető korosztály iskolázottsági szintjét (idetartoznak a rurális térségek és a nem önálló törvényhatósági jogú városok is), hasonló etnikai-felekezeti alapú arányeltolódásokat tapasztalhatunk: az izraelita férfiaknak 7,2, a nőknek pedig 10,3\%-a volt írástudatlan. A férfiaknak 12,2\%-a végzett négy osztályt és 13,8\%-uk nyolc osztályt. A zsidó nők esetében ezek az értékek 16,1, illetve 1,6\%-ot mutattak. A görög katolikus népesség körében az elmaradás még szembeötlőbb a városi adatokhoz képest. A történelmi Erdély falvaiban és nem törvényhatósági jogú városaiban élő, 20-24 éves görög katolikus férfiaknak 56,7, a nőknek pedig 73,5 \%-a nem tudott írni-olvasni. A férfiaknak 0,6 \%-a rendelkezett négyosztályos végzettséggel és 1,6\%-uk nyolc osztállyal. A nőknél ezek az arányok még kedvezőtlenebbeknek bizonyultak: Négy osztályt $0,6 \%$ végzett, a nyolc osztályt kijárt személyek aránya pedig alig volt mérhető $(0,1 \%)$. A római katolikus férfiak körében az írástudatlanság $13,2 \%$, a reformátusok körében 16,9\%, az evangélikusok esetében 3,4\%, a görögkeletieknél 45\% és az unitáriusok körében 13,4\% volt (Karády 2009: 290-301). 



\section{AZ ERDÉLYI/ROMÁNIAI OKTATÁSI RENDSZER JOGI HÁTTERE ÉS SZERKEZETE}

Az első világháború végéig az erdélyi oktatási rendszer a magyarországi rendszer részét képezte. Erdélynek (korábban Magyarország része), Bukovinának (Ausztria) és Besszarábiának (Oroszország) Romániához történő csatolása azt is jelentette, hogy az új tartományokat jogi és közigazgatási téren is integrálni kellett az új állami keretekbe. Erdély integrációjának egyik legfontosabb eszköze a nagyszebeni román Kormányzótanács (Consiliul Dirigent) volt, amelyet egy 1918. december 11-i törvényrendelettel hoztak létre, és amelyre egyfajta Erdély közigazgatását ellátó szerv szerepe hárult.

Az első, oktatást érintő intézkedések az 1920-ig fennálló Kormányzótanácshoz füződtek. Az erdélyi tanügyi intézményrendszer romániai integrációjára vonatkozó törvények, rendeletek viszont többéves folyamat részeként láttak napvilágot. Azt is látni kell, hogy a különböző romániai régiók oktatási rendszerének egységesítése lényegében egybeesett az oktatási rendszer megreformálását célzó törekvésekkel.

Tekintettel Erdély etnikai viszonyaira, az oktatás és a kulturális intézményháló terén kiemelten fontos szerep jutott a kisebbségeknek. A nemzeti kisebbségek tanszabadságára már az 1918. december 1-jén elfogadott Gyulafehérvári határozatok 1. pontja utalást tett. A következő évben, 1919. december 9-én, Románia aláírta a párizsi Kisebbségi szerződést, amely már nemcsak elismerte a kisebbségek saját anyanyelvű oktatáshoz való jogát, hanem konkrét intézkedéseket is tartalmazott ennek biztosítására (9-11. cikkek). A 9. cikk rendelkezett arról, hogy Románia kisebbségeinek joguk van saját költségükön jótékonysági, vallási és szociális intézményeket, valamint oktatási és nevelőintézményeket felállítani és működtetni. Ezekben szabadon használhatják anyanyelvüket, és korlátozások nélkül gyakorolhatják vallásukat. A szerződés következő cikkei lehetőséget biztosítottak 
arra, hogy azokon a településeken, ahol jelentős kisebbségi lakosság él, az állami elemi iskolákban a nem román gyermekek saját anyanyelvükön tanulhassanak. Ugyanakkor fenntartották annak a lehetőségét, hogy a kisebbségi gyermekek számára is kötelezővé tegyék a román nyelv oktatását. Biztosították továbbá a kisebbségek oktatási, nevelési, vallási és jótékonysági intézményeinek méltányos állami finanszírozását (Nagy 1944: 117, 219).

Az első világháborút követő román tanügyi törvénykezés csak részben tett eleget a Gyulafehérvári határozatokban és a Kisebbségi szerződésben foglaltaknak. Ez elsősorban a korábban államalkotó nemzet szerepét betöltő erdélyi magyarság oktatásügyére nézve bizonyult hátrányosnak. De ugyanígy az erdélyi német/szász és zsidó oktatás is jelentős nehézségekbe ütközött.

A román uralom alá került erdélyi területeken (történelmi Erdély, Bánság, Partium) 1919-ben az elemi iskoláknak hetvenkét százaléka volt felekezeti és községi jellegü, huszonnyolc százalékát pedig az állam tartotta fenn. Ami a tanítási nyelvet illeti, 44,7\%-uk volt román, 48,4\%-uk pedig magyar nyelvú iskola (Bíró 2002: 351).

1918 decemberében a nagyszebeni román Kormányzótanács irányításával megkezdődött az erdélyi magyar állami iskolák románosítása. A Kormányzótanács állandó biztosai átvették az iskolák leltárait, és bevezették a román nyelv kötelező tanítását. A következő tanévtől, azaz 1919/1920-tól román állami tulajdonba került az összes magyar állami és királyi katolikus oktatási intézmény (bővebben lásd Iancu 1970: 251-265).

A románosítások nem csupán az iskolarendszer átalakulását hozták magukkal (a kisebbségi felekezetek kisebbségi tanítási nyelvű iskolákat nyitottak), hanem a tanszemélyzet számára és helyzetére is kihatással bírtak. Az erdélyi román oktatók közül sokat felszívott az újonnan berendezkedő román adminisztráció, a kisebbségek esetében pedig problémákat jelentett a tanerők utánpótlása (Balogh 1996: 39).

1919. január 24-én rendeletben szabályozták az erdélyi oktatásügyet. A rendelet lényegében megelőlegezte az 1924 után meghozott oktatással kapcsolatos román törvények szellemiségét. Az állami elemi iskolák tanítási nyelvének tekintetében úgy rendelkezett, hogy az az illető településen többséget alkotó népesség etnikumának/anyanyelvének függvényében dől el. A településeken belül kisebbségben élő etnikumok számára anyanyelven tanító párhuzamos osztályok létesítését tette lehetővé. A rendelet a községi, felekezeti, alapítványi és magániskolák esetében a tanítás nyelvét az iskolafenntartó döntéskörébe utalta. Az állami középiskolák tanítási nyelvének esetében a megyében többséget alkotó etnikum volt a döntő, a 
felsőoktatásban pedig az illető régió többségi nyelvét vették figyelembe (Szlucska 2009: 14-15).

A továbbiakban az 1924 utáni, oktatásra vonatkozó főbb jogi szabályozásokat ismertetjük kronológiai sorrendben. Az oktatásnak a két világháború közötti megszervezése több fázisban történt, amelynek legfontosabb elemeit az 1924-es elemi oktatási törvény, az 1925-ös magánoktatási, az 1928-as középiskolai és az 1932-es felsőoktatási törvény, valamint a kereskedelmi és ipari oktatás 1936-os szabályozásai alkották. Az egyházi oktatási intézmények helyzetét és ezzel együtt lényegében a kisebbségi oktatás kereteit is az 1925-ös magánoktatási törvény határozta meg. Első lépésben az állami oktatásnak a két világháború közötti kereteit, majd a magánoktatási törvényt ismertetjük. Ezt követően térünk rá az 1940-1944 közötti periódus tárgyalására, amely a merőben új geopolitikai helyzet (Észak-Erdély Magyarországhoz kerül, Dél-Erdély Romániánál marad) és a megváltozott belpolitikai viszonyok következtében külön ismertetést igényel. A harmadik fázisban az újból ugyanazon adminisztratív határok közé került (Románia) erdélyi területek 1944/1945 és 1948 közötti oktatásügyének jogi ismertetésére vállalkozunk.

\subsection{Az oktatásügy 1918-1940 között}

\subsubsection{Az elemi oktatás}

A háború utáni román tanügyi törvényhozás egyik legfontosabb és a kisebbségek szempontjából is jelentős alkotása az 1924. július 26-án megjelent, az állami elemi iskolai oktatásról és tanitóképzésról szóló törvény (Legea învățământului primar-normal) volt, amely 1934-ben és 1937-ben részleges módosításokon ment keresztül. A törvény az elemi oktatás rendszeréhez tartozó napközi otthonok, elemi iskolák, iskolás kort meghaladó személyek számára szánt tanfolyamok, képzések, valamint szellemi és egészségügyi fogyatékossággal rendelkező gyermekek nevelésével foglalkozó speciális iskolák müködését és a tanítóképzést szabályozta. Az elemi oktatás színtereként három kategóriát állított fel: nyilvános állami tanintézmények, az állam által engedélyezett magánoktatási intézmények (ezeknek a működését 1925-ben külön törvényben szabályozták) és a családban zajló nevelés. A három kategória közül az elsővel, tehát az állami oktatási intézmények müködésével foglalkozott a törvény. Idetartoztak mind az állam által, mind az egyes községek vagy megyék által létrehozott és a Közoktatásügyi Minisztérium által engedélyezett oktatási intézmények. A törvény szerint az állami elemi iskolákat az illető községek tartották fent, 
ezek működtetéséhez az állam csakis a tanítók fizetésének biztosításával járult hozzá. Ugyanígy az iskolaépületeket, és azok felszereléseit is a községek kellett, hogy biztosítsák. Az állami iskolákban tanuló diákokra nem rótt anyagi terhet a törvény. Az ingyenes állami elemi oktatás és az állami iskolák számában bekövetkezett növekedés tehát egyre nagyobb réteg számára biztosította az alfabetizációt.

Az 1924-es törvény rendelkezése értelmében az elemi oktatás megszervezése és irányítása kizárólag állami feladat volt. Az állam ezt a jogkörét a Közoktatásügyi Minisztériumon keresztül gyakorolta. Ennek megfelelően sem állami, sem magán/egyházi elemi iskolát nem lehetett felállítani előzetes minisztériumi engedély és a törvényi keretek tiszteletben tartása nélkül. A törvény mindezek mellett leszögezte azt is, hogy az elemi iskolai oktatás az egész országban egységes és azonos program szerint müködik (Enciclopedia României 1938: 468). Az állami elemi oktatás nyelveként egységesen a románt állapította meg. A törvény viszont lehetővé tette azt, hogy azokon a településeken, ahol a lakosság anyanyelve nem román, ott a kisebbségek számára is nyithatnak állami iskolákat. Ezekben a tanítási nyelv az illető kisebbség nyelve volt, de a román nyelv tanítása is kötelező maradt.

Igen súlyosan érintette a kisebbségeket az a kitétel, amely szerint az olyan román származású állampolgárok, akik „,anyanyelvüket elvesztették", kötelesek román tanítási nyelvú állami vagy magániskolába íratni a gyermekeiket, még abban az esetben is, ha olyan településen élnek, ahol a lakosság többsége nem román anyanyelvü. A törvény 8.§-a módot adott az iskolai hatóságoknak arra is, hogy ellenőrizzék a gyermekek származását, és ennek alapján megtiltsák vagy engedélyezzék a kisebbségi iskolák látogatását számukra. Ez a rendelkezés nagyon sok esetben vezetett visszaélésekhez a nemzetiségek rovására (Nagy 1944: 121).

Az elemi iskolai oktatásról szóló törvény, a tanítási nyelv és az iskolák jogi viszonya mellett külön foglalkozott a tanulókkal és a pedagógusokkal. Kötelezővé, de ugyanakkor ingyenessé tette minden iskoláskorú gyermek számára az elemi iskolák látogatását. Ennek értelmében elrendelte a tanköteles gyermekek (5-16 évesek) évenkénti összeírását, amelyre a szeptember 1-10. közötti időszakot jelölte ki. Az iskolakerülést pénzbüntetéssel sújtották.

A tankötelezettség tekintetében több kategóriát állított fel a törvény: Az 5-7 éves gyermekek számára az elemi oktatásra felkészítő óvodákat hoztak létre. A törvény 1926-os végrehajtási utasítása szerint ezeket az intézményeket elsősorban ott kellett müködtetni, ahol „nemzetiségüket elvesztett románok laknak" (Nagy 1944: 122). A 7-16 évesek számára az 
elemi iskolák látogatása volt kötelező. A 16-18 év közötti fiatalok részére ún. felnőttképző iskolákat, tanfolyamokat létesítettek.

Az elemi iskolákat a korábbi négyről hétosztályosra bővítették, és ennek a bővítési folyamatnak minden iskola esetében 1930-ig le kellett zárulnia (Kornis 1927: 22). Az elemi iskolák I-IV. osztályai képezték az elemi oktatás alsó szintjét. Ezeknek a tanrendje országos szinten azonos volt, és lényegében az oktatás további szintjeinek a megalapozását szolgálták. Az I-IV. osztályokban a következő tantárgyakat tanították: írás-olvasás, hit- és erkölcstan, román nyelv, gyakorlati számtan és mértan, Románia történelme, földrajza és alkotmánytana, természettan és természetrajz, egészségtan, rajz, ének, testnevelés, kézimunka. Mindehhez hozzáadódott a fiúk esetében a gazdasági gyakorlatok tanítása (falvakon) és a lányok esetében a háztartástan. A kisebbségek számára ugyanakkor lehetővé tette az anyanyelven történő tanítást. Ezzel szemben az állami iskolák V-VII. osztályaiban a tanítás nyelve kizárólag csak a román lehetett (Kornis 1927: 22).

Az elemi oktatás második szintjét az V-VII. osztályok képezték. Ezeknek a korábban megszerzett tudásanyagnak az elmélyítése és bővítése mellett a szakirányú, gyakorlati nevelés is célja volt. Ennek következtében a tanrend itt már nem volt egységes, hanem a regionális, helyi sajátosságokat is figyelembe vette. A tantárgyak ugyanazok maradtak, mint az alsó tagozaton, itt viszont már bővebb ismeretanyagot sajátíthattak el a tanulók és mezőgazdasági, illetve ipari szakirányú képzésben is részesülhettek.

A felnőttképző iskolák és tanfolyamok rendszerét az írni-olvasni nem tudó 16-18 éves korosztály és az elemi iskolát nem végzett 12-18 év közötti fiatalok részére hozták létre. Ezen oktatási intézmények látogatása alól csak azokat a 18 év alatti személyeket mentették fel, akik az elemi iskola I-IV. osztályait elvégezték. A tanítás nyelve kizárólag román volt, nem véve figyelembe a nemzeti kisebbségekhez tartozó fiatalok igényeit. A tanrend lényegében sürített formában foglalta magába az I-IV. osztályok tananyagát.

Ugyancsak az 1924-es állami elemi iskolai törvény szabályozta a testi vagy szellemi fogyatékkal élő gyermekek oktatását is. Ezeket a különleges iskolákat a közoktatási és népjóléti minisztériumok működtették, magát az oktatás szervezését viszont a közoktatásügyi minisztérium látta el.

A törvény rendelkezése szerint csupán azok a fiatalok kaphattak bizonyítványt az elemi iskola elvégzéséről, akik mind a hét osztályt kijárták. A tanulók számának tekintetében úgy határoztak, hogy az alsóbb tagozatokon egy-egy osztály létszáma 60, míg az V-VII. évfolyamokon 40 lehet. A tanerők számát az iskolások alapján szabták meg. Igy abban az esetben, ha a tanulók száma 60 alatt volt, az illető iskolának egy tanítót kellett alkalmaznia. 60-120 közötti diáklétszám esetében kettőt, 120-160 között 
hármat és 160-220 között négy tanítót irányoztak elő. Abban az esetben, ha az elemi iskola alsó tagozatában a diákok száma meghaladta a 220-at, akkor külön leányiskolát is kellett nyitni (Enciclopedia României 1938: 469, Kornis 1927: 22).

A tanerők státusát illetően a törvény két kategóriát állított fel. Az első kategóriába tartoztak a rendes tanítók, akiket négy további csoportba soroltak: ideiglenes tanítók (a képesítővizsgát követően első kinevezésüket töltő tanítók), végleges tanítók (legalább 3 évi szolgálat és véglegesítő vizsga után), előléptetett II. fokú tanító (olyan végleges tanító, aki fokozati vizsgát tett), előléptetett I. fokú tanító (minimum 6 évi szolgálat után, a II. fokozat birtokában lehetett elérni). A második kategóriába a segédtanítók két csoportja tartozott, és azok közül kerültek ki, akik nem végeztek tanítóképzőt: ideiglenes helyettes tanítók (legalább 4 középiskolai osztályt kellett végeznie), segédtanítók (olyan személyek, akik legalább négy évig szolgáltak ideiglenes helyettes tanítóként, vagy a líceumot végzettek, illetve olyan tanítóképzőt járt személyek, akik nem tették le a képesítővizsgákat).

A tanítók képzését külön erre a célra felállított oktatási intézmények látták el. Itt mind az elemi iskolák, mind az óvodák számára készítettek fel tanerőket. A tanítóképzők kezdetben hét, majd nyolc osztállyal működtek. Az első hároméves (később négy) ciklusban a növendékek a gimnáziumokéhoz hasonló képzésben részesültek. Az utolsó négy évben, tehát a második ciklusban már szakirányú tanítás folyt. A tanítóképzőkbe az elemi iskola alsó tagozatának, azaz az I-IV. osztályoknak az elvégzése után lehetett bekerülni felvételi vizsga révén (Statistica învățământului 1931: XI).

A törvény 228. §-a szerint állami tanító csak olyan személy lehetett, aki beszélte a román nyelvet. A már képesítéssel rendelkező, nem román anyanyelvü tanítókat emellett arra kötelezték, hogy vizsgát tegyenek román nyelvből, Románia földrajzából, történelméből és alkotmánytanából (Nagy 1944: 190).

A tanítók továbbképzését az általános tanítói gyưlések, a kulturális körök, továbbképző tanfolyamok és a szaktudásukat elvesztett tanítók számára szervezett ismétlő tanfolyamok biztosították.

Külön képesítő-kiegészítő tanfolyamokat szerveztek az olyan kisebbségi tanerők számára, akik nem román tanítási nyelvű állami elemi iskolában dolgoztak. Ezeken a tanfolyamokon román nyelvet, Románia történelmét és földrajzát, valamint alkotmánytant adtak le. Azok a kisebbségi tanítók pedig, akiknek a tanfolyam végén nem sikerült az említett tantárgyakból tett pótképesítő vizsgájuk, a következő évben is meg kellett, hogy ismételjék a kurzusokat. Másodszori bukás esetén elveszítették állásukat. 
Az állami iskolai rendes tanítók fizetése alapfizetésből és korpótlékból tevődött össze. A képesítés nélküli segédtanítók az ideiglenes okleveles tanítók fizetésének $75 \%$-át kapták. A korpótlékokat a tanügyben ledolgozott évek alapján állapították meg. Így az 5 éves rendes tanítói régiséggel rendelkező személyek az alapfizetésük alapján kiszámított 25\%-os pótlékban részesültek. Tíz év szolgálat után ez az arány 50\%, 15 év után 75\%, 20 év után 100\% és 25 év után 125\% volt (Kornis 1927: 28).

A törvény ismertetése végén szólni kell a kisebbségekre nézve sérelmes kultúrzónákról. A kultúrzónákat a törvény 159. §-a alapján hozták létre olyan megyékben, ahol a nemzetiségek éltek többségben vagy jelentős számban. Az itt letelepedő, más megyéből származó román tanítók 50\%-os fizetési pótlékot, telket (10 hektár) kaptak, és korábban mehettek nyugdíjba (Diószegi-R. Süle 1990: 26). ${ }^{5}$ A rendelkezés nem titkolt célja volt a kisebbségek elrománosításának felgyorsítása (Nagy 1944: 123, Livezeanu 1995: 140-141).

Az 1924-es állami elemi oktatási törvény 1939-ig maradt érvényben. Ekkor, 1939. május 27-én tették közzé az állami elemi iskolai oktatásról, valamint a tanitóképzésról szóló törvényrendeletet (Decret-lege pentru organizarea şi funcționarea învățământului normal şi primar). A megváltozott román belpolitikai viszonyok (1938 februárjától a demokratikus berendezkedést királyi diktatúra váltotta fel) új alkotmány megszavazását és új törvények életbe léptetését hozták magukkal. Az új tanügyi törvény különös hangsúlyt fektetett az állami elemi iskolák nemzeti nevelőszerepére. A tanítás nyelveként a románt írta elő, megengedve viszont, hogy az olyan vidékeken, ahol jelentős számú kisebbség él, az illető kisebbség nyelvén tanító iskolákat hozzanak létre. Hasonlóan az 1924-es előírásokhoz, ez esetben is kötelező volt a kisebbségi nyelven oktató iskolák számára a román nyelvnek a tanítása. Emellett viszont Románia történelmét, földrajzát és alkotmánytanát is román nyelven kellett oktatni. Az új törvény érvényben hagyta a kultúrzónákat is (Nagy 1944: 125). Mindemellett viszont egy sor reformtörekvést is tartalmazott. Az új törvény nagyobb hangsúlyt fektetett a gyakorlati oktatásra és az iskolák didaktikai eszközeinek bővítésére. Ez volt az első olyan romániai elemi oktatást szabályozó törvény, amely konkrétan meghatározta az iskolák keretében müködő kiegészítő intézményeket: iskolai étkezde, gyógyszertár, tornacsapatok, ipari műhely, mezőgazdasági telep, könyvtár, kórus stb. (Diac 2004: 258).

\footnotetext{
${ }^{5}$ A következő erdélyi, főként magyar népességű megyék tartoztak a kultúrzónához: Csík, Háromszék, Udvarhely, Maros-Torda, Bihar, Szatmár, Szilágy, Kolozs, Szolnok-Doboka, Torda-Aranyos. Ezenkívül kultúrzónának számítottak a bolgárok által lakott dobrudzsai Durostor és Caliacra, valamint az orosz és ukrán kisebbséget magáénak tudó bukovinai, illetve besszarábiai Vijnița, Zastava, Coțmani, Hotin, Tighina, Cetatea-Albă, Ismail megyék is (Nagy 1944: 123, Diószegi-R. Süle 1990: 26).
} 


\subsubsection{A középiskolai oktatás}

A két világháború közötti középiskolai oktatást az 1928. május 15-i Hivatalos Közlönyben megjelent középfokú oktatásról szóló törvény (Lege pentru învățământul secundar) szabályozta. A törvény megállapítása szerint a középfokú oktatás két színtéren zajlott: az állami tanintézményekben és az 1925-ös magánoktatási törvényben meghatározott egyházi, egyesületi vagy más magánjellegü iskolákban.

Habár az évek során több módosításon ment keresztül, az 1939-ben elfogadott új középfokú elméleti oktatási törvényig az 1928-as törvény maradt érvényben. A két világháború közötti középfokú oktatás a következő kategóriákat foglalta magában: elméleti oktatás, tanítóképzés, teológiai szemináriumok, illetve főiskolák, ipari oktatás, kereskedelmi oktatás, mezőgazdasági képzés, valamint katonai oktatás (Enciclopedia României 1938: 471). A különböző középiskolai szintű oktatási intézményekbe azok nyerhettek felvételt, akik elvégezték legalább az elemi iskolák alsó tagozatát, azaz az I-IV. osztályt.

Az elméleti középiskolai oktatás két, egymástól önállóan működő szinten zajlott. Az első szintet képviselték a hároméves gimnáziumok, ahová az elemi iskolák első négy osztályát elvégző diákok kerülhettek be 11 éves kortól. Ezen a szinten az általános múveltséghez szükséges ismereteket lehetett elsajátítani. Az oktatási program egységes volt minden iskolában, a fiúk és a lányok számára viszont külön képzéseket is tartottak. A felső, líceumi szint négyéves képzést biztosított, de itt már az általános ismeretek elmélyítésén túl az első 3 évben szakirányú oktatás zajlott. Az utolsó évben pedig a hangsúly az egyetemi tanulmányokra történő felkészítés jegyében telt. Azokat az elméleti középiskolákat, amelyek csak alsó szintű képzést biztosítottak, azaz csak I-III. osztállyal működtek, gimnáziumoknak nevezték. Abban az esetben, ha az illető középiskola csak a felső szinttel, tehát a IV-VII. osztályokkal vagy mind a két fokozattal (I-VII. osztályok) müködött, líceumnak minősült. Változást jelentett a korábbi középiskolák szerkezetéhez képest az, hogy a törvény egységesítette a felső ciklusokat, azaz megszüntette a korábbi klasszikus, modern és reál szakirányokat (Statistica învățământului 1931: XII).

A törvény 17. §-a értelmében azok a tanulók, akik sikeresen letették a III. osztály utáni vizsgát, igazolást kaptak arról, hogy elvégezték a gimnáziumot. Mindazoknak, akik líceumi szinten kívánták a tanulmányaikat folytatni, felvételizniük kellett a IV. osztályba. ${ }^{6}$ A líceumi tanulmányok elvégeztével csak azok a tanulók nyerhettek a felsőoktatási intézményekbe

\footnotetext{
${ }^{6}$ A gimnáziumból líceumba történő felvételi kötelezettségét egy 1925. március 8-i törvény írta elő (Statistica Învățământului 1931: XII).
} 
felvételit, akik sikeresen letették az érettségi vizsgát. A szóbeliből és írásbeliből álló vizsga legfőképpen a kisebbségeket és közöttük is a magyarokat érintette a leghátrányosabban, ami az igen rossz baccalaureatusi eredményekben is tetten érhető (Lásd részletesebben: Bíró 2002: 384-386).

A tanítók utánpótlását, azaz a tanítóképzést külön erre a célra felállított intézmények végezték, az 1924-es állami elemi iskolai oktatásról és tanítóképzésről szóló törvény alapján (a vonatkozó rendelkezések ismertetését lásd fentebb).

A teológiai szemináriumok, illetve főiskolák rendeltetése a papi utánpótlás biztosítása volt. A növendékeket ide az elemi iskola első négy osztályának az elvégzése után vették fel. A teológiai képzés egyházanként változott. Erdélyi viszonylatban elsősorban három nagyobb rendszerről beszélhetünk. Az elsőt az inkább román lakossághoz köthető görögkeleti papok képzése céljából működő papi szemináriumok alkották. A második rendszerbe tartoztak a nyugati kereszténység kötelékébe tartozó római katolikus és protestáns egyházak által működtetett teológiák. A harmadikba pedig a zsidóság papi utánképzése.

A mezőgazdasági ismeretek továbbadását szakirányú iskolák és ismeretterjesztő tanfolyamok végezték. Az iskolai képzést I. és II. fokú fiú- és leány mezőgazdasági, valamint lányok számára létesített I. és II. fokú háziipari iskolák látták el. A mezőgazdasági ismereteket terjesztő tanfolyamok is több kategóriára oszlottak, és közös jellemzőjük volt, hogy nem a Közoktatásügyi Minisztériumtól, hanem a Mezőgazdasági Minisztériumtól függtek. Ezek lehettek téli mezőgazdasági iskolák fiúk és lányok számára, mezőgazdasági kisegítő személyzetet képző iskolák, időszaki mezőgazdasági tanfolyamok, valamint mezőgazdasági előadások. Ami a törvényi hátteret illeti, a mezőgazdasági oktatási rendszer jogi szabályozásával az 1929. augusztus 2-án a Hivatalos Közlönyben közzétett a mezögazdasági és háziipari I. és II. fokú oktatás, valamint a népszerüsitô oktatás szervezetéról szóló törvény (Lege pentru organizarea învățământului agricol şi casnic de gradul I şi II şi de popularizare) foglalkozott. Az oktatás nyelveként a románt határozták meg, engedélyezve viszont a kisebbségek által lakott területeken a kisebbségi nyelveken történő oktatást is.

A királyi diktatúra elején újabb törvényt hoztak a mezőgazdasági oktatás szabályozásának céljából. Az 1938. szeptember 30-án megjelent, alsó-és középfokú mezőgazdasági oktatásról (Lege pentru organizarea învățământului agricol mediu, inferior şi de popularizare) címet viselő törvény rendelkezett arról, hogy mezőgazdasági középiskolát csak az állam tarthat fent (Nagy 1944: 133). 
A kereskedelmi és ipari oktatás egységes jogi szabályozására csak 1936-ban került sor. A középfokú kereskedelmi iskolákról szóló törvény (Lege pentru organizarea învățământului comercial secundar) április 1-jén jelent meg. Egyik legfontosabb hozadéka a kereskedelmi oktatás államosítása és a román tanítási nyelv általánossá tétele volt. Az oktatás két szinten zajlott. Az alsó, négyéves gimnáziumi képzésre az elemi iskola első négy osztályának elvégzése után vették fel a növendékeket. A felsőbb, ugyancsak négyéves líceumba a kereskedelmi gimnáziumok végzőseit vették fel. A kereskedelmi gimnáziumok végzősei egyébként nemcsak kereskedelmi, hanem elméleti líceumban is folytathatták tanulmányaikat.

Az ipari oktatást az 1936. április 16-i középfokú kereskedelmi iskolákról szóló törvény (Lege pentru organizarea şi funcționarea învățământului secundar industrial de băieți şi fete) az állam kizárólagos feladatkörébe utalta. Az oktatás nyelveként a románt határozta meg, és három kategóriát különböztetett meg. Az első kategóriába tartoztak a négyéves ipari gimnáziumok, amelyekbe az elemi iskola I-IV. osztályait követően lehetett beiratkozni. A második kategóriába a négyosztályos ipari líceumi képzés tartozott. Ide az elméleti oktatást nyújtó intézményekből vagy ipari gimnáziumokból iratkozhattak be a diákok. A harmadik kategóriát a kétéves ipari iskolák képezték. Ezekbe az elemi iskolák első négy osztályának elvégzése után vették fel a növendékeket.

A középiskolai oktatás rendszerébe tartoztak a katonai líceumok. Nyolcéves képzést nyújtottak, amelyekre az elemi iskola I-IV. osztályának elvégzése után lehetett felvételt nyerni. Az általános műveltséghez szükséges ismeretek mellett a növendékek katonai képzésben is részesültek. Ezek az oktatási intézmények a Hadügyminisztérium kötelékébe tartoztak (Enciclopedia României 1938: 472-473).

A Románia új alkotmányának elfogadása utáni évben, 1939. november 4-én hirdették ki a középfokú oktatást újraszabályozó középfokú elméleti oktatásról szóló rendelettörvényt (Decret-lege pentru organizarea şi funcționarea învățământului secundar teoretic). A törvény nem változtatott az állami és magániskolákra vonatkozó korábbi rendelkezéseken, sem az iskolalétesítési és fenntartási jogon. Újjászervezte viszont az érettségi rendszert, arra hivatkozva, hogy a korábbi években megszerzett igen magas számú érettségi következtében az egyetemek túljelentkezésekkel küszködnek. Az új rendszer főleg a románul gyengébben tudó kisebbségi diákokat érintette hátrányosan, ugyanis a törvény értelmében a román nyelv ismerete „különös elbírálás alá" esett az érettségin (Nagy 1944: 129). 
Új eleme volt az 1939-es törvénynek a román nemzeti nevelés hangsúlyosabbá tétele. Ennek fényében az összes középiskolai tanárt a Nemzeti Újjászületés Frontba (Frontul Renaşterii Naţionale) történő belépésre kötelezte. ${ }^{7}$

Az állami középfokú oktatás módositásáról (Decret-lege pentru modificarea unor art. din decretul lege pentru organizarea şi funcționarea învățământului secundar teoretic din 4. nov. 1939) újabb rendelettörvény jelent meg 1940-ben. Ebben a törvényhozó, a megváltozott külföldi politikai körülményekre és a román nemzeti kultúra igényeire hivatkozva, a német vagy olasz nyelv valamelyikének a kötelező középiskolai oktatását írta elő (Nagy 1944: 129).

\subsubsection{Az egyházi, egyesületi és magániskolák helyzete}

Erdély Romániához csatolását követően a települések állami iskolái a román állam felügyelete alá kerültek. Ez lényegében azt jelentette, hogy a korábban többségében magyar tanítási nyelvü állami oktatási intézményrendszer román tanítási nyelvűvé vált. Az intézményi változásokon túl az iskolák románosítása azzal járt, hogy a kisebbségek anyanyelvi oktatása az egyházakra hárult.

A román Hivatalos Közlönyben 1925. december 22-én jelent meg a magánoktatási törvény (Lege asupra învățământului particular), amely szabályozta az egyházak, egyesületek által müködtetett oktatási intézményeket és a magánjellegü iskolákat. A törvény szerint bármely román állampolgár felállithatott iskolát. Mindezt egyénileg vagy társulva is megtehették, amennyiben erre engedélyt kaptak a Közoktatásügyi Minisztériumtól. Ezeknek az intézményeknek az ellenőrzését, felügyeletét a minisztérium végezte.

A tanítási nyelv tekintetében úgy határozott a törvény, hogy azokban a magánoktatási intézményekben, amelyekben román eredetú szülők gyermekei járnak, románul folyik az oktatás. Egyéb iskolákban a tanítási nyelvet az iskolafenntartó határozza meg (tehát az illető egyház vagy egyesület), de csak olyan gyermekeket lehet ide felvenni, akiknek az anyanyelve azonos az illető oktatási intézmény tanítási nyelvével. Ez a rendelkezés korábban ismeretlen akadályokat gördített a kisebbségi egyházi iskolák elé: lényegében csak azokat a diákokat vehették fel, akik a saját nemzeti közösségükhöz tartoztak. Ilyen értelemben a leghátrányosabban az erdélyi magyar anyanyelvủ és magyar identitású zsidóságot érintette a törvény.

\footnotetext{
${ }^{7}$ A Nemzeti Újjászületési Frontot II. Károly hozta létre a királyi diktatúra bevezetését követően. A Front a beszüntetett politikai pártok helyét vette át, és mint kizárólagos politikai szervezet múködött. Az élén maga a király állt (Scurtu 2003: 391-393).
} 
Őket ugyanis, ellentétben a korábbi magyar állami gyakorlattal, a román állam nem a magyarság részének, hanem különálló nemzeti kisebbségnek tekintette. A zsidó diákok többsége így kiszorult a keresztény felekezetek iskoláiból (Lásd Kolozsvár esetét: Gidó 2012: 519-532).

Külön paragrafus foglalkozott a zsidók által fenntartott magániskolák kérdésével. Az ő esetükben tanítási nyelvként az állam nyelvét, tehát a románt vagy a „zsidó” nyelvet írta elő. Habár a magyar anyanyelvű erdélyi zsidó iskolák számára a magyar tanítási nyelv megtiltása komoly erőpróbát jelentett (kezdetben a legtöbb iskola nem is tudott eleget tenni a törvény előírásainak, mert a tanerők és a diákok sem ismerték kellő mértékben a román vagy a héber nyelvet), az a lehetőség, hogy választhatnak a román vagy a zsidó között, kibúvókra adott lehetőséget. ${ }^{8}$ A törvény ugyanis nem határozta meg pontosan azt, hogy mit is ért zsidó nyelv alatt. Így ezt az iskolafenntartók saját belátásuk szerint értelmezhették jiddisként vagy héberként is (Gyémánt 2004: 106).

A törvény elöírása szerint, függetlenül a magániskolák tanítási nyelvétől, Románia földrajzát, történelmét és alkotmánytanát kötelező módon románul kellett oktatni. Az említett tantárgyakat pedig „,csak román nyelvet ismerő, képesített tanárok" taníthatták (Nagy 1944: 135).

Az egyházak, közületek által fenntartott vagy egyéb magánjellegü óvodák abban az esetben taníthattak valamely kisebbség nyelvén, ha az odajáró gyermekek között nem volt román ajkú. Ellenkező esetben az oktatási nyelv az állam nyelve kellett, hogy legyen.

A magániskolák önállóságát korlátozta a törvény azon rendelkezése, amely szerint nem állíthattak ki okleveleket, csak egyszerü igazolásokat. Ez alól csak esetenként volt kivétel. A magániskolák (kisebbségi iskolák) tanulóinak így az állami iskolákban kellett letenniük a vizsgáikat.

Habár a törvény általános rendelkezése szerint magánosok nem létesíthettek tanítóképzőket, a már 1918 előtt alapított és azóta folyamatosan funkcionáló hasonló tanintézmények működését továbbra is engedélyezték. A tanszemélyzet tekintetében egy sor előírást tartalmazott a törvény. Megkövetelte, hogy a tanárok román állampolgársággal rendelkezzenek, és az állami iskolák pedagógusaihoz hasonló képesítésük legyen. Alapkövetelmény volt a román nyelv ismerete, amelyet a román állam által kiállított oklevéllel vagy külön vizsgával kellett igazolni. A külön vizsga románnyelv-ismeretbőll, Románia történelméből, földrajzából és alkotmánytanából állt. Mindazon személyeket, akik a törvény hatályba lépését

\footnotetext{
${ }^{8}$ Az 1925-ös magánoktatási törvényt megelőzően is születtek már próbálkozások az erdélyi zsidó iskolák tanítási nyelvének a megváltoztatására. 1922 júniusában például a kolozsvári tankerületi felügyelőség (Directoratul General Cluj) rendeletben tiltotta meg, hogy a zsidó iskolák a magyar nyelvet használják az oktatás nyelveként. Új Kelet 1922. június 13., 126. sz., Magyar Nép 1922. június 24., 25. sz.
} 
követő öt éven belül nem tették le a nyelvvizsgát vagy elbukták azt, megfoszthatták állásuktól. A nyelvvizsga kötelezettsége alól csak az 55. évüket betöltött vagy legalább 30 év régiséggel rendelkező pedagógusok mentesültek.

\subsubsection{A felsőoktatás}

Az egyetemi oktatás működését 1932-ig az 1912-es román felsőoktatási törvény szabályozta. Az időközben eltérő közigazgatási és jogi rendszerű területekkel bővült Romániának viszont szüksége volt egy olyan törvényre, amely egységesen szabályozza az egyetemi és főiskolai szintü képzést. Ezt a jogi igényt teljesítette az 1932. április 22-i egyetemi oktatásról szóló törvény (Lege pentru învățământul universitar). 1932-ig viszont meg kellett oldani az 1918 után Romániához került területeken működő felsőoktatási intézmények helyzetét. Erdély esetében ez legélesebben a kolozsvári Ferenc József Tudományegyetem esetében merült fel. A magyar állami felsőoktatási intézményként működő egyetemet 1919-ben október 1-jei hatállyal románná nyilvánította a román állam. Mindezt egy 1919. szeptember 23-án kihirdetett törvényben tette meg (Lege pentru transformarea Universității Maghiare din Cluj în Universitate românească). Az oktatás nyelve a román lett, kicserélődött az oktatói kar, és az épületek, felszerelések, tehát az intézményi infrastruktúra a román állam tulajdonába ment át. Hasonlóképpen, azaz egy 1919-ben meghozott törvény révén zajlott le a cernăuți-i német tanítási nyelvű egyetem románosítása is (Lege pentru transformarea Universității Germane din Cernăuți în Universitate românească) (Nagy 1944: 133-134). Ugyancsak román tanítási nyelvűvé vált 1919/1920-tól a Nagyváradi Királyi Jogakadémia, valamint az 1921/1922-es tanévtől a Kolozsvári Gazdasági Akadémia és a Kolozsvári Kereskedelmi Akadémia (Szlucska 2009: 25).

Az 1932-es egyetemi oktatásról szóló törvény értelmében egyetemet csak az állam tarthatott fenn. Ez alól csupán a lelkészképző intézetek és a katonai akadémiák jelentettek kivételt. Ez lényegében azt jelentette, hogy a Románia területén élő kisebbségek vagy egyházak, egyesületek, magánosok csak teológiai irányultságú felsőoktatási intézményeket hozhattak létre és müködtethettek. Egyéb téren nem vehettek részt a felsőoktatásban (Nagy 1944: 134). A katonai akadémiák a Hadügyminisztérium hatáskörébe tartoztak.

A romániai/erdélyi felsőoktatási intézményekbe érettségivel rendelkező fiatalokat vettek fel. A tanulmányi idő minimum 3 évet tett ki, és a diákok tandíjat, valamint vizsgadíjakat fizettek. A két világháború közötti román egyetemi szféra a következő karokat foglalta magában: orvosi, ál- 
latorvosi, gyógyszerészeti, természettudományi, jogi, bölcsész, teológiai. Az egyetemi tanulmányok elvégzését szakdiploma, illetve doktori diploma igazolta. A főiskolák az egyetemi diplomákhoz hasonló bizonyítványokat állítottak ki a végzősök számára (Enciclopedia României 1938: 473).

\subsection{Az oktatásügy 1940-1944 között}

Az 1940. augusztus 30-i második bécsi döntés nyomán Erdélyt két részre osztották. Észak-Erdély Magyarországhoz került vissza, míg DélErdély Romániánál maradt. Az 1940-1944 közötti időszak oktatásügyét tehát két állam törvénykezése határozta meg. Magyarország az 1938-1941 közötti területi gyarapodásoknak köszönhetően nemcsak területét növelte meg, hanem újból jelentős számú kisebbségi lakosság került a határai közé. A visszacsatolt területek népességének 49,5\%-a kisebbségi, azaz nem magyar nemzetiségű volt. Az új etnikai viszonyok új szabályozásokat is igényeltek: a magyarországi kisebbségi népoktatás újraszabályozását szolgáló rendeletet 1941. február 1-jén léptették életbe. A rendelet megengedte a kisebbségek anyanyelven történő oktatását, ugyanakkor kötelezővé tette a magyar nyelv oktatását is. A kisebbségi oktatásügy területén a magyar kormány kettős elveket követett. Amíg a trianoni országrészen a vegyes, azaz az illető kisebbség anyanyelvén és magyarul folyó oktatást támogatta, addig a visszacsatolt területeken a teljes körü anyanyelvi oktatás bevezetése felé hajlott (Tóth 1998: 16-17).

Az oktatásszervezés terén is változások következtek be, az észak-erdélyi oktatási intézményrendszert igyekeztek a magyarországival összhangba hozni. Az első világháború utáni román iskolapolitika a korai specializálódásra épített. Ennek következtében az ipari, háztartási iskolákba már 10 éves kortól vették fel a diákokat, a tanítás pedig általában két tagozaton folyt (egy 3-4 vagy 5 éves alsó és egy 3 vagy 4 éves felső tagozat). Esetenként ezeknek az iskoláknak az alsó tagozata önálló egységet is alkothatott. Magyarországon viszont az 1934-es középiskolai reformot követően (1934:XI. tc.) egységes középiskolai alsó tagozatok, azaz gimnáziumok működtek. Ezt egészítette ki az 1938:XIII. tc., amely a pályaválasztás lehetőségét a diákok 14. életévéig tolta ki. ${ }^{9}$

A második bécsi döntés után a magyar Vallás- és Közoktatásügyi Minisztérium hozzákezdett az észak-erdélyi oktatás magyarországi típusú átszervezéséhez. Visszaállították a román Közoktatásügyi Minisztérium által megszüntetett polgári iskolákat, és visszamagyarosították az 1919/1920-ban elrománosított állami és királyi katolikus tanintézménye-

\footnotetext{
${ }^{9}$ Magyar Országos Levéltár (a továbbiakban: MOL) K592, 689. csomó, 4. tétel, Erdélyi gimnáziumok nyilvántartása, 195.
} 
ket. Az önállóan működő alsó fokú szakiskolákat fokozatosan tanonciskolákká alakították át. Azokat a szakiskolákat, amelyek felső tagozattal is rendelkeztek, polgári iskolává szervezték át. A négy évfolyamú ipari fiúés leánylíceumokat ipari középiskolává változtatták. Az önállóan működő ipari gimnáziumokat pedig ipari szakiskolává alakították. (Az ipari szakiskolákba azok kerülhettek be, akik elvégeztek legalább négy év polgárit, vagy azzal egyenlő értékü iskolát). Az alsó fokú ipari iskolákat (şcoli inferioare de meserii) iparos tanonciskolákká szervezték át. Változások következtek be a háztartási és főzőiskolák terén is. Ezek kétéves háztartási gazdasági szaktanfolyamokká minősültek át. A kereskedelmi oktatási intézmények terén szintén történtek módosítások. A kereskedelmi fiú- és leánylíceumokat kereskedelmi középiskolákká, a kereskedelmi gimnáziumokat pedig polgári iskolákká minősítették át.

\subsection{Az oktatásügy 1944-1948 között}

A két világháború közötti időszakhoz képest, az oktatási intézményrendszer nem ment keresztül lényegi változásokon 1948-ig.

Az 1948. augusztus 3-i tanügyi reform (175-ös törvényrendelet) szocialista szellemben készült el, és egy új korszakot nyitott a romániai oktatásügy történetében. Kizárólag világi oktatást engedélyezett (a lelkészképzésen kívül), a következő rendszerben: iskola előtti tanintézmények (óvodák, napközi otthonok), elemi iskolák két ciklussal (1-4. osztály a 7-11. éves gyermekek számára és 5-7. osztály a 11-14. éves tanulók számára), különböző típusú középiskolák (4 évfolyamos szakiskolák, líceumok, tanítóképzők, technikumok), felsőoktatás (egyetemek és egyetemi szintü felsőfokú tanintézmények) (Giurescu 1971: 348).

A törvény értelmében az ország minden lakosának egyenlő módon volt joga tanulmányokat folytatni. Az összes egyházi és magániskolák az állam tulajdonába mentek át. A felsőoktatást érintő rendelkezések leszögezték, hogy Romániában kéttípusú felsőoktatási intézmény működik majd a továbbiakban: egyetemek és politechnikák.

Az egyetemeken folytatott tanulmányok idejét a törvény 4-6 évben szabta meg. Újdonságnak számított az, hogy 2 éves speciális iskolákat hoztak létre, amelyek a középiskolai tanulmányok pótlását voltak hivatottak betölteni. Ide elsősorban érettségivel nem rendelkező, munkásszármazású személyeket vettek fel, akik a két év elvégzése után jogot kaptak arra, hogy egyetemekre felvételizzenek (Nicoară 2010: 347).

Az 1948-as reform révén a romániai oktatás teljes mértékben átpolitizálódott és a Kommunista Párt ellenőrzése alá került. A középiskolai és egyetemi felvételiknél előnyben részesítették a munkásszármazású diáko- 
kat, ezzel szemben a nagypolgárság vagy a kulákok gyermekeit hátrányos megkülönböztetések érték, sok esetben nem folytathatták tanulmányaikat sem. A kommunista vezetés szemében az iskolák többek között arra szolgáltak, hogy pártkádereket, hűséges pártkatonákat termeljenek ki (Tismăneanu-Dobrincu-Vasile 2007: 290, Bunescu 2004: 17). 


\section{AZ ERDÉLYI TANINTÉZMÉNYEK 1918-1940 KÖZÖTT}

A romániai oktatási rendszert teljes egészében átfogó részletes statisztikák főként a két világháború közötti időszakra nézve készültek. Az 1919-1929-es periódus adatait két, a Közoktatásügyi és Vallásügyi Minisztérium által publikált statisztikai összefoglaló közölte. Az első, amelyet 1924-ben adtak ki, az 1919/1920 és az 1920/1921-es tanéveket foglalja magában (Statistica învățământului 1924). Segítségével az 1918-tól Romániához tartozó Erdély (értve ezalatt a történelmi Erdélyt, Bánságot és a Partiumot) oktatásügyének impériumváltás kori helyzetéről kaphatunk információkat. Mivel a román kormány a korábbi erdélyi állami, magyar nyelven oktató oktatási intézményeket románosította, az 1920-as évek elejére lényegesen átalakult az erdélyi oktatási intézményhálózat. 1924-ben elfogadták az állami elemi iskolákról és tanítóképzésről szóló törvényt, majd egy évvel később a magánoktatási törvényt, amelyek újabb átalakulásokat eredményeztek az oktatási rendszerben. Ezeket a változásokat lehet nyomon követni az 1931-ben megjelent újabb statisztikai összefoglaló segítségével, amely az 1921-1929 közötti időszakról közöl adatokat (Statistica învățământului 1931).

A fent említett két összegzés mellett további négy koncentrált forrás állt a rendelkezésünkre a két világháború közötti időszakra nézve: az 1925-ben publikált Anuarul învățământului particular de grad secundar az 1923/1924-es tanévben müködő egyházi, magán és társulati középfokú tanintézményeket veszi leltárba (Anuarul învățământului particular 1925). Ellentétben a már említett többéves összefoglalókkal, itt minden egyes tanintézmény név szerint és a legfontosabb adatok feltüntetésével szerepel (alapítási év, székhely, tanítási nyelv, diákok létszáma, tanárok fizetése stb.). Ugyancsak hasonló felépítésben jelent meg 1925-ben az állami középfokú iskolák adatait tartalmazó évkönyv (Anuarul învățământului secundar 1925) 
és 1927-ben a kereskedelmi oktatás évkönyve (Anuarul învățământului comercial 1927). A negyedik korpusz az 1939/1940-es tanévben működő egyházi és magán elemi iskolákról közöl statisztikát (Tabloul şcolilor primare 1940).

Igen fontos forrásanyagnak bizonyultak a román statisztikai évkönyvek. Segítségükkel és a már említett összefoglalók alapján szinte teljes adatsorokat sikerült összeállítani az 1919-1938 közötti időszakra (Anuarul Statistic 1933: 340-365., Anuarul Statistic 1934: 316-347., Anuarul Statistic 1935: 400-433., Anuarul Statistic 1939: 201-267., Anuarul Statistic 1940: 241-299).

A tanulmány elején utaltunk már arra, hogy a különböző oktatási szinteken tanuló diákok számára, illetve az egyes etnikumokra, felekezetekre vonatkozó román statisztikai eredmények pontosságát, hitelességét a két világháború között többen is kétségbe vonták. Most csak Rónai András 1934-es cikkére hivatkozunk, amelyben a román statisztikák nemzetiségi eredményeit vitatja. Rónai szerint már az problémát jelent, hogy „,a román tanügyi statisztikát román tanfelügyelők és tanítók állítják össze", akiknek a többségében magyar vagy egyéb kisebbségek által lakott településeken érdekükben áll a ténylegesnél nagyobb számú román és kisebb számú nemzetiségi tanulót feltüntetni. Hiszen így a saját, állam által fizetett állásuk létjogosultságát tudják indokolni. Számításai szerint az 1920-as évek közepén mintegy 300 000, 6-14 év közötti magyar tanköteles gyermek volt Erdélyben, a román statisztikák viszont 100 000-rel kevesebbet mutattak ki. Rónai mindezt az egyházi statisztikák, népszámlálási adatok és a román iskolastatisztikák összevetése alapján állította (Rónai 1934: 851-871). Az adatok esetleges pontatlanságának lehetőségét egyébként maguk a statisztikát készítő szakemberek is elismerték. Az általunk közölt kimutatások elsősorban mégis a román statisztikai közleményekre támaszkodnak, mivel a hozzáférhető feldolgozások közül ezek a legátfogóbbak.

A két világháború közötti időszakra vonatkozó kimutatásaink a fentebb felsorolt korpuszok alapján készültek. Az alább szereplő 1918-1938 közötti időszakra vonatkozó táblázatoknál csak azokat a forrásokat tüntetjük fel, amelyek ebben a felsorolásban nem szerepeltek.

A második világháború éveire és az azt követő, 1948-as államosításokkal lezáruló periódusra már jóval szórványosabb információk álltak a rendelkezésünkre. Itt elsősorban Szlucska János monográfiájára (Szlucska 2009) támaszkodhattunk, valamint néhány levéltári forrásra és a Magyar statisztikai évkönyv köteteire.

Az alább közreadott táblázatok szerkesztési módszerével kapcsolatosan a következőket kell megjegyeznünk: A román statisztikai kiadványokban a kimutatások első oszlopában minden esetben a román vagy a 
görögkeleti, valamint a görög katolikus népességre vonatkozó adatok szerepelnek. Ezeket követik az egyéb nemzetiségek, köztük a németek, majd a magyarok és a zsidók. Az elsősorban felekezeti adatokat közlő magyar statisztikákban ezzel szemben a magyarokra vagy a római katolikusokra és protestánsokra vonatkozó számok szerepelnek az első helyeken. Mivel a statisztikák etnikai és vallási megoszlást mutató rubrikáinak sorrendje a román és a magyar állam kategorizációs logikáját mutatja, úgy tartottuk helyesnek, ha minden esetben megőrizzük a hivatalos kimutatások eredeti szerkezetét.

\subsection{Iskoláskorúak}

A továbbiakban az 1919 utáni erdélyi iskoláskorú népesség számának alakulására nézve közlünk adatokat. Azt követően pedig az Erdélyben élő, számbelileg fontosabb népcsoportok (románok, magyarok, németek, zsidók) oktatásának jellegzetességeit ismertetjük.

Az erdélyi iskoláskorúak számának alakulásáról az 1924-1937-es periódusra nézve rendelkezünk információkkal. 1924-ben 744000 volt a 7-16 éves fiatalok száma. A következő évtől viszont már az 5-18 éves korosztály létszáma meghaladta az egy milliót. Az alábbiakban az 5-18 éves iskoláskorú fiatalok számának alakulását követhetjük figyelemmel (lásd még az 1. sz. mellékletet):

8. Az iskoláskorúak számának alakulása Erdélyben 1924-1937 között:10

\begin{tabular}{|c|c|}
\hline $\mathbf{1 9 2 4}$ & 744070 \\
\hline $\mathbf{1 9 2 5}$ & 1102990 \\
\hline $\mathbf{1 9 2 6}$ & 1053113 \\
\hline $\mathbf{1 9 2 7}$ & 1050706 \\
\hline $\mathbf{1 9 2 8}$ & 1067510 \\
\hline $\mathbf{1 9 2 9}$ & 1051813 \\
\hline $\mathbf{1 9 3 1}$ & 1088688 \\
\hline $\mathbf{1 9 3 3}$ & 1130186 \\
\hline $\mathbf{1 9 3 6}$ & 1187761 \\
\hline
\end{tabular}

Az iskoláskorú gyermekek számának folyamatos emelkedése az általános romániai/erdélyi demográfiai tendenciákat követte. Az 1910-es és az 1930-as népszámlálás között 5,6\%-kal gyarapodott Erdély lakossága, 1941-re pedig 12,5\%-ra nőtt ez az arány 1910-hez képest. Az iskoláskorúak

\footnotetext{
${ }^{10}$ Az 1924-es adat csak a 7-16 éves iskoláskorúak számát mutatja.
} 
számának terén 1925 és 1937 között közel 99 000-es növekedést tapasztalhatunk, amely 9\%-os növekedést jelent.

Erdély etnikai képéhez hasonlóan az iskoláskorú gyermekek között a román nemzetiségűek voltak többségben, őket a magyarok, majd a németek és a zsidók követték. Jelentős volt továbbá a főként Máramaros vidékén élő ukránok/ruténok, a bánsági szerbek és bolgárok száma is (lásd a 2. és 3. sz. mellékleteket). A románok, magyarok, németek és zsidók aránya a következő módon alakult:

9. Az erdélyi iskoláskorúak etnikai megoszlása 1924-1937 között:

\begin{tabular}{|c|c|c|c|c|c|c|c|c|c|c|}
\hline & \multicolumn{2}{|c|}{ Román } & \multicolumn{2}{|c|}{ Német } & \multicolumn{2}{|c|}{ Magyar } & \multicolumn{2}{|c|}{ Zsidó } & \multirow{2}{*}{ Egyéb } & \multirow{2}{*}{$\begin{array}{l}\text { Össze- } \\
\text { sen }\end{array}$} \\
\hline & & $\%$ & & $\%$ & & $\%$ & & $\%$ & & \\
\hline 1924 & 438538 & 58,9 & 76354 & 10,3 & 176657 & 23,7 & 28645 & 3,8 & 23876 & 744070 \\
\hline 1925 & 654785 & 59,4 & 104185 & 9,4 & 276199 & 25,0 & 36851 & 3,3 & 30970 & 1102990 \\
\hline 1926 & 625472 & 59,4 & 104180 & 9,9 & 258725 & 24,6 & 33082 & 3,1 & 31654 & 1053113 \\
\hline 1927 & 636078 & 60,5 & 97020 & 9,2 & 251356 & 23,9 & 34671 & 3,3 & 31581 & 1050706 \\
\hline 1928 & 648279 & 60,7 & 97036 & 9,1 & 256116 & 24,0 & 34607 & 3,2 & 31535 & 1067573 \\
\hline 1929 & 645014 & 61,3 & 92998 & 8,8 & 250825 & 23,8 & 33040 & 3,1 & 29936 & 1051813 \\
\hline 1931 & 672029 & 61,7 & 96152 & 8,8 & 253356 & 23,3 & 33841 & 3,1 & 33310 & 1088688 \\
\hline 1933 & 710136 & 62,8 & 98572 & 8,7 & 254974 & 22,6 & 32197 & 2,8 & 34307 & 1130186 \\
\hline 1936 & 761626 & 64,1 & 99947 & 8,4 & 254488 & 21,4 & 32740 & 2,8 & 38960 & 1187761 \\
\hline 1937 & 781816 & 65,1 & 96104 & 8,0 & 251249 & 20,9 & 33165 & 2,8 & 39382 & 1201716 \\
\hline
\end{tabular}

Míg az iskoláskorú román fiatalok aránya folyamatosan növekedett a két világháború között, addig - a korszak demográfiai folyamatainak megfelelóen - a németek, a magyarok és a zsidók esetében folyamatos csökkenés tapasztalható. 1925-ben a román nemzetiségüek 59,4\%-ot, a magyarok 25\%-ot, a németek 9,4-et és a zsidók 3,3\%-ot alkottak, 1931-re a többségi nemzet aránya 61,7\%-ra emelkedett, a kisebbségeké pedig visszaesett. 1937-re tovább folytatódott ez a tendencia, a románok részesedése 65,1\%-ra emelkedve, a magyaroké pedig 20,9-re, a németeké 8-ra és a zsidóké 2,8\%-ra zsugorodva. 


\section{2. Óvodák}

Az oktatás legalsó lépcsőfokának számító óvodák száma az 1920-as évek elején ugrott meg. Közvetlenül az impériumváltást követő tanévben 257 óvoda múködött Erdély területén. Ezekből 147 volt állami, 62 egyházi, 47 községi és 1 magánjellegü.

10. Az erdélyi óvodák megoszlása az 1919/1920-as tanévben:

\begin{tabular}{|c|c|c|c|c|c|c|c|c|c|}
\hline & \multirow[b]{2}{*}{ 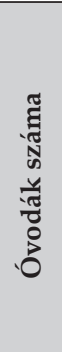 } & \multirow[b]{2}{*}{ 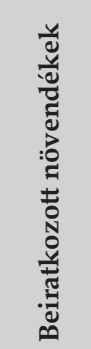 } & \multicolumn{3}{|c|}{$\begin{array}{l}\text { Tényleges } \\
\text { frekventálás }\end{array}$} & \multicolumn{3}{|c|}{ Tanerők } \\
\hline & & & & 注 & 孞 & 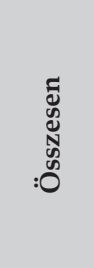 & 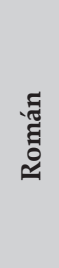 & 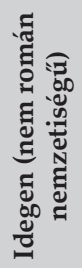 & 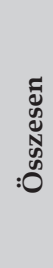 \\
\hline \multicolumn{2}{|c|}{ Állami } & 147 & 6251 & 3030 & 3069 & 6099 & 92 & 60 & 152 \\
\hline \multicolumn{2}{|c|}{ Községi } & 47 & 2964 & 1397 & 1528 & 2925 & 7 & 43 & 50 \\
\hline \multicolumn{2}{|c|}{ Magán } & 1 & 72 & 35 & 37 & 72 & - & 1 & 1 \\
\hline \multirow{10}{*}{ 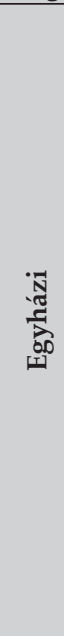 } & $\begin{array}{l}\text { Román } \\
\text { görögkeleti }\end{array}$ & 4 & 406 & 171 & 184 & 355 & 4 & - & 4 \\
\hline & $\begin{array}{l}\text { Szerb } \\
\text { görögkeleti }\end{array}$ & - & - & - & - & - & - & - & - \\
\hline & $\begin{array}{l}\text { Román } \\
\text { görög } \\
\text { katolikus }\end{array}$ & - & - & - & - & - & - & - & - \\
\hline & Lutheránus & 36 & 2373 & 1153 & 1169 & 2322 & - & 43 & 43 \\
\hline & Református & 4 & 194 & 89 & 92 & 181 & - & 5 & 5 \\
\hline & $\begin{array}{l}\text { Római } \\
\text { katolikus }\end{array}$ & 15 & 926 & 438 & 477 & 915 & 1 & 17 & 18 \\
\hline & Unitárius & - & - & - & - & - & - & - & - \\
\hline & Izraelita & 2 & 125 & 60 & 62 & 122 & - & 2 & 2 \\
\hline & \begin{tabular}{|l} 
Egyéb \\
egyház
\end{tabular} & 1 & 65 & 31 & 34 & 65 & - & 1 & 1 \\
\hline & $\begin{array}{l}\text { Összes } \\
\text { egyházi }\end{array}$ & 62 & 4089 & 1942 & 2018 & 3960 & 5 & 68 & 73 \\
\hline \multicolumn{2}{|c|}{ Összesen } & 257 & 13376 & 6404 & 6652 & 13056 & 104 & 172 & 276 \\
\hline
\end{tabular}

Az állami óvodák tanítási nyelve a román volt, a kisebbségek által nagyobb számban lakott településeken pedig az adott kisebbség nyelve. 
Az egyházi óvodákat elsősorban azok az egyházak működtették, amelyeknek hívei túlnyomórészt a magyarok, németek vagy a zsidók közül kerültek ki. Itt is kiemelkedtek a lutheránusok, amelyek az egyházi óvodáknak több mint a felét tartották fent. Őket a római katolikus, református és izraelita intézmények követték. A tanerők etnikai összetétele ugyancsak az állami és egyházi óvodák mentén körvonalazódik. Az egyházi intézményekben a pedagógusokból 5, azaz 6,8\% volt csupán román etnikumú. Közülük egy római katolikus, 4 pedig görögkeleti óvodákban tanított. Ezzel szemben az állam által működtetett intézményekben a román oktatók alkottak 60,5\%-os többséget. A főként kisebbségek által lakott területeken múködő községi óvodákban ugyancsak alulreprezentált volt a román tanszemélyzet.

A további időszakra nézve nem rendelkezünk hasonlóan részletes statisztikákkal az óvodák jellegét illetően. Az 1927-1929-es időszakot leszámítva csupán az állami intézmények számának alakulásáról és növendékeiről készültek átfogó korabeli kimutatások. Itt viszont igen jelentős gyarapodásnak lehetünk tanúi, főleg az óvodák működését is szabályozó 1924-es állami elemi oktatásról szóló törvény elfogadását követően. Az 1925/1926-os tanévben, az előző évhez képest, 49,5\%-al nőtt az állami óvodák száma, elsősorban a kisebbségek által lakott területeken. Az új törvény 1926-os végrehajtási utasítása, amely a „nemzetiségüket elvesztett románok" által lakott területeken szorgalmazta az óvodák müködtetését, újabb ugrásszerú növekedést idézett elő: 1926/1927 és 1927/1928 között 36\%-kal lett több óvoda Erdélyben (Nagy 1944: 122).

Az egyházi, egyesületi és magánóvodák száma az impériumváltás időszakához viszonyítva szintén emelkedett valamelyest, de látható, hogy ezt a típusú oktatást elsősorban az állam látta el. Az 1927/1928-as tanévben 79, egy évvel később pedig 89 volt a számuk. Ezekben az években állami óvodából 487, illetve 556 működött Erdély-szerte (lásd még a 4. sz. mellékletet).

11. Állami óvodák száma Erdélyben:

\begin{tabular}{|c|c|}
\hline & Intézmények száma \\
\hline $\mathbf{1 9 2 1 / 1 9 2 2}$ & 99 \\
\hline $\mathbf{1 9 2 2 / 1 9 2 3}$ & 125 \\
\hline $\mathbf{1 9 2 3 / 1 9 2 4}$ & 173 \\
\hline $\mathbf{1 9 2 4 / 1 9 2 5}$ & 208 \\
\hline $\mathbf{1 9 2 5 / 1 9 2 6}$ & 311 \\
\hline $\mathbf{1 9 2 6 / 1 9 2 7}$ & 358 \\
\hline $\mathbf{1 9 2 7 / 1 9 2 8}$ & 487 \\
\hline $1928 / 1929$ & 556 \\
\hline
\end{tabular}




\begin{tabular}{|l|l|}
\hline $\mathbf{1 9 3 0 / 1 9 3 1}$ & 673 \\
\hline $\mathbf{1 9 3 1 / 1 9 3 2}$ & 675 \\
\hline $\mathbf{1 9 3 2 / 1 9 3 3}$ & 666 \\
\hline $\mathbf{1 9 3 5 / 1 9 3 6}$ & 763 \\
\hline $\mathbf{1 9 3 6 / 1 9 3 7}$ & 807 \\
\hline
\end{tabular}

Az állami óvodák növendékeinek közel felét a román gyermekek tették ki. A magyarok 1/3 arányban voltak jelen, míg a németek 9-15\%-ot tettek ki. A zsidók aránya folyamatos csökkenést mutatott, amely a nemzetiségi arányok kiegyenlítődésének a számlájára írható. Míg az 1920-as évek elején 8-9\% körül mozgott a rátájuk az állami óvodákban, addig az 1936/1937-es tanévre már csak 3,5\%-ot alkottak (lásd az 5. sz. mellékletet). Látható viszont a román nemzetiségü óvodások alulképviseltsége, amely mindvégig megmaradt a két világháború között mind az állami, mind az egyházi intézményekben. A jelenséget egyaránt okozta az, hogy főként a nemzetiségek által nagyszámban lakott területeken müködtek óvodák és az, hogy a román népességet általában aluliskolázottság jellemezte ebben az időszakban.

12. Az állami óvodák növendékeinek etnikai megoszlása:

\begin{tabular}{|c|c|c|c|c|c|c|c|c|c|c|c|}
\hline & \multicolumn{2}{|c|}{ Román } & \multicolumn{2}{|c|}{ Német } & \multicolumn{2}{|c|}{ Magyar } & \multicolumn{2}{|c|}{ Zsidó } & \multicolumn{2}{|c|}{ Egyéb } & \multirow{2}{*}{$\begin{array}{l}\text { Ösz- } \\
\text { szesen }\end{array}$} \\
\hline & & $\%$ & & $\%$ & & $\%$ & & $\%$ & & $\%$ & \\
\hline $1921 / 1922$ & 2125 & 49,1 & & & & & 406 & 9,4 & 1797 & 41,5 & 4328 \\
\hline $1922 / 1923$ & 3335 & 49,4 & & & & & 662 & 9,8 & 2752 & 40,8 & 6749 \\
\hline $1923 / 1924$ & 5616 & 50,2 & & & & & 887 & 7,9 & 4692 & 41,9 & 11195 \\
\hline $1924 / 1925$ & 6915 & 46,1 & & & & & 1201 & 8,0 & 6891 & 45,9 & 15007 \\
\hline $1925 / 1926$ & 10201 & 45,7 & 2589 & 11,6 & 7489 & 33,5 & 1703 & 7,6 & 361 & 1,6 & 22343 \\
\hline $1926 / 1927$ & 12429 & 45,4 & 4195 & 15,3 & 8499 & 31,0 & 1643 & 6,0 & 640 & 2,3 & 27406 \\
\hline $1927 / 1928$ & 16527 & 47,8 & 4270 & 12,3 & 11282 & 32,6 & 1798 & 5,2 & 702 & 2,0 & 34579 \\
\hline $1928 / 1929$ & 19244 & 47,6 & 5606 & 13,9 & 12642 & 31,3 & 2058 & 5,1 & 839 & 2,1 & 40389 \\
\hline $1930 / 1931$ & 19307 & 45,4 & 4815 & 11,3 & 15716 & 37,0 & 1912 & 4,5 & 738 & 1,7 & 42488 \\
\hline 1931/1932 & 19287 & 46,6 & 4691 & 11,3 & 15279 & 36,9 & 1870 & 4,5 & 256 & 0,6 & 41383 \\
\hline $1932 / 1933$ & 19526 & 46,5 & 4651 & 11,1 & 15077 & 35,9 & 1925 & 4,6 & 809 & 1,9 & 41988 \\
\hline $1935 / 1936$ & 21966 & 48,3 & 4703 & 10,3 & 15937 & 35,0 & 1888 & 4,2 & 983 & 2,2 & 45477 \\
\hline $1936 / 1937$ & 24554 & 49,9 & 4265 & 8,7 & 17621 & 35,8 & 1741 & 3,5 & 1060 & 2,2 & 49241 \\
\hline
\end{tabular}

Az egyházi és magánóvodákban, tükrözve a müködtetők arányát, a német gyermekek száma volt a domináns, őket a magyarok követték 20-26\%-al. A románok és a zsidók aránya is elenyésző volt, habár mindkettő esetében enyhe növekedés tapasztalható. 
13. Az egyházi és magánjellegú óvodák növendékeinek etnikai megoszlása:

\begin{tabular}{|c|c|c|c|c|c|c|c|c|c|c|c|}
\hline & \multicolumn{2}{|c|}{ Román } & \multicolumn{2}{c|}{ Német } & \multicolumn{2}{c|}{ Magyar } & \multicolumn{2}{c|}{ Zsidó } & \multicolumn{2}{|c|}{ Egyéb } & Összesen \\
\cline { 2 - 12 } & & $\mathbf{\%}$ & & $\%$ & & $\%$ & & $\%$ & & $\%$ & \\
\hline $\mathbf{1 9 2 7 / 1 9 2 8}$ & 85 & 1,2 & 5002 & 71,6 & 1814 & 26,0 & 84 & 1,2 & 4 & 0,1 & 6989 \\
\hline $\mathbf{1 9 2 8 / 1 9 2 9}$ & 219 & 2,9 & 5475 & 73,5 & 1507 & 20,2 & 236 & 3,2 & 7 & 0,1 & 7444 \\
\hline
\end{tabular}

Az állami intézményekbe járó óvodások felekezeti megoszlásáról csak az 1925-ös tanévtől kezdődően rendelkezünk részletes adatokkal. 1925-1937 között a görögkeleti vallású óvodások 30,1-34,3\%-ot alkottak, a görög katolikusok pedig 13,2-16,9\%-ot, amely az etnikai mutatókhoz hasonlóan jelentős aluliskolázottságot jelez a két felekezet esetében. A túlnyomórészt magyar, kisebb részben bolgár és német nemzetiségű római katolikusok, reformátusok és unitáriusok aránya együttesen $41-47 \%$ volt, míg a német és magyar evangélikusok 1,9-3,4\%-ot tettek ki. A többségében magyar kultúrájú és magyar kötődésú izraelita vallású gyermekek aránya 3,5-7,6\% között mozgott ebben az időszakban.

14. Az állami óvodák növendékeinek felekezeti megoszlása:

\begin{tabular}{|c|c|c|c|c|c|c|c|c|c|}
\hline & 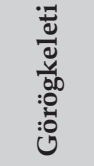 & 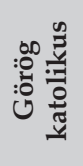 & 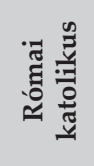 & 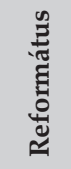 & & 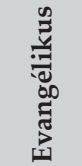 & 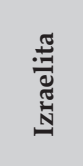 & 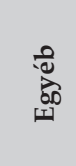 & 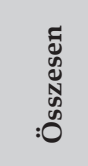 \\
\hline 1921/1922 & 1601 & & & & & & 406 & 2321 & 4328 \\
\hline $1922 / 1923$ & 2492 & & & & & & 662 & 3595 & 6749 \\
\hline $1923 / 1924$ & 4232 & & & & & & 887 & 6076 & 11195 \\
\hline $1924 / 1925$ & 5126 & & & & & & 1201 & 8680 & 15007 \\
\hline $1925 / 1926$ & 7270 & 2939 & 6344 & 3085 & 488 & 415 & 1703 & 99 & 22343 \\
\hline $1926 / 1927$ & 8610 & 3954 & 7578 & 4059 & 531 & 934 & 1643 & 97 & 27406 \\
\hline $1927 / 1928$ & 11853 & 4913 & 8731 & 5362 & 716 & 1100 & 1798 & 106 & 34579 \\
\hline $1928 / 1929$ & 13558 & 6035 & 10510 & 6155 & 881 & 1050 & 2058 & 142 & 40389 \\
\hline $1930 / 1931$ & 12803 & 6391 & 11906 & 7258 & 1049 & 918 & 1912 & 251 & 42488 \\
\hline $1931 / 1932$ & 13272 & 6335 & 11506 & 6694 & 869 & 1011 & 1870 & 281 & 41838 \\
\hline $1932 / 1933$ & 13309 & 6353 & 11997 & 6473 & 806 & 918 & 1925 & 207 & 41988 \\
\hline $1935 / 1936$ & 15130 & 7707 & 11219 & 7631 & 807 & 882 & 1888 & 213 & 45477 \\
\hline $1936 / 1937$ & 17142 & 7980 & 11515 & 7933 & 890 & 1741 & 1741 & 299 & 49241 \\
\hline
\end{tabular}


15. Az állami óvodák növendékeinek felekezeti megoszlása százalékban kifejezve:

\begin{tabular}{|c|c|c|c|c|c|c|c|c|}
\hline & 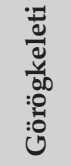 & 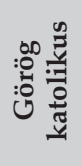 & 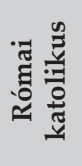 & 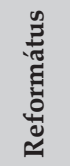 & 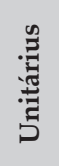 & 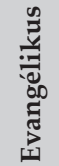 & 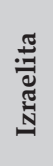 & $\overbrace{000}^{00}$ \\
\hline $1921 / 1922$ & 37,0 & & & & & & 9,4 & 53,6 \\
\hline $1922 / 1923$ & 36,9 & & & & & & 9,8 & 53,3 \\
\hline $1923 / 1924$ & 37,8 & & & & & & 7,9 & 54,3 \\
\hline $1924 / 1925$ & 34,2 & & & & & & 8,0 & 57,8 \\
\hline $1925 / 1926$ & 32,5 & 13,2 & 28,4 & 13,8 & 2,2 & 1,9 & 7,6 & 0,4 \\
\hline 1926/1927 & 31,4 & 14,4 & 27,7 & 14,8 & 1,9 & 3,4 & 6,0 & 0,4 \\
\hline $1927 / 1928$ & 34,3 & 14,2 & 25,2 & 15,5 & 2,1 & 3,2 & 5,2 & 0,3 \\
\hline $1928 / 1929$ & 33,6 & 14,9 & 26,0 & 15,2 & 2,2 & 2,6 & 5,1 & 0,4 \\
\hline $1930 / 1931$ & 30,1 & 15,0 & 28,0 & 17,1 & 2,5 & 2,2 & 4,5 & 0,6 \\
\hline 1931/1932 & 31,7 & 15,1 & 27,5 & 16,0 & 2,1 & 2,4 & 4,5 & 0,7 \\
\hline $1932 / 1933$ & 31,7 & 15,1 & 28,6 & 15,4 & 1,9 & 2,2 & 4,6 & 0,5 \\
\hline $1935 / 1936$ & 33,3 & 16,9 & 24,7 & 16,8 & 1,8 & 1,9 & 4,2 & 0,5 \\
\hline $1936 / 1937$ & 34,8 & 16,2 & 23,4 & 16,1 & 1,8 & 3,5 & 3,5 & 0,6 \\
\hline
\end{tabular}

\subsection{Elemi oktatás}

Amíg az óvodai képzés csak egy töredékét fedte le a gyermekeknek, addig az elemi iskolai rendszer szinte teljes egészében átfogta az iskolaköteles növendékeket. Az alábbiakban az állami elemi iskolák és azok pedagógusai számának alakulását követhetjük nyomon. A két világháború közötti időszakban jelentős növekedés tapasztalható mind az iskolák, mind a tanerők számának alakulását illetően. 1920-ban az állami és községi elemik száma 1572-t tett ki. Ezzel szemben 1921-ben Erdélyben már összesen 3044 állami elemi iskola múködött és 1936-ra 4570-re ugrott a számuk, amely közel háromszoros emelkedést jelentett 1921-hez képest. A tanerők esetében ez az arány viszont három és félszeres volt (lásd az 5. sz. mellékletet). A leglátványosabb növekedés 1922 és 1923 között következett be, ekkor 667-tel lett több állami elemi iskola Erdélyben. Constantin Angelescu tanügyminisztersége első évében, 1922-ben kezdődött ugyanis el az országos iskolaépítési kampány (Angelescu 1939: 13).

Az állami intézmények számának gyarapodásával párhuzamosan az ellehetetlenített egyházi és magánjellegư elemik néhány év alatt közel harmadával csökkentek: 1920-ban összesen 3223 egyházi iskola müködött, 1927-ben már csak 1210. 
16. A különbözó típusú elemi iskolák száma az 1920/1921-es tanévben:

\begin{tabular}{|l|l|c|c|}
\hline \multicolumn{2}{|l|}{} & Iskolák száma & $\begin{array}{c}\text { Beiratkozott } \\
\text { növendékek }\end{array}$ \\
\hline Állami & 1218 & 160791 \\
\hline Községi & Román görögkeleti & 354 & 23134 \\
\hline Magán & 19 & 854 \\
\hline \multirow{5}{*}{ Egyházi } & Szerb görögkeleti & 1031 & 79929 \\
\cline { 2 - 4 } & Román görög katolikus & 34 & 2467 \\
\cline { 2 - 4 } & Rutén görög katolikus & 768 & 50691 \\
\cline { 2 - 4 } & Római katolikus & 18 & 1035 \\
\cline { 2 - 4 } & Református & 423 & 46576 \\
\cline { 2 - 4 } & Unitárius & 669 & 55232 \\
\cline { 2 - 4 } & Evangélikus & 65 & 1879 \\
\cline { 2 - 4 } & Izraelita & 180 & 30611 \\
\cline { 2 - 4 } & Egyéb egyház & 32 & 4083 \\
\cline { 2 - 4 } & Összes egyházi & 3223 & 272588 \\
\hline \multirow{5}{*}{ Összesen } & & 4814 & 457367 \\
\hline
\end{tabular}

17. Az állami elemi iskolák és tanerôik száma:11

\begin{tabular}{|c|c|c|c|c|c|}
\hline & Fiú & Lány & Vegyes & Összesen & $\begin{array}{c}\text { Tanerők } \\
\text { száma }\end{array}$ \\
\hline $1921 / 1922$ & 60 & 71 & 2913 & 3044 & 5867 \\
\hline $1922 / 1923$ & 17 & 18 & 3580 & 3615 & 5928 \\
\hline $1923 / 1924$ & 10 & 8 & 3673 & 3691 & 6048 \\
\hline $1924 / 1925$ & 14 & 11 & 3724 & 3749 & 6923 \\
\hline $1925 / 1926$ & 21 & 19 & 3680 & 3720 & 7460 \\
\hline $1926 / 1927$ & 17 & 17 & 3810 & 3844 & 7774 \\
\hline $1927 / 1928$ & 20 & 16 & 3950 & 3986 & 8310 \\
\hline $1928 / 1929$ & 19 & 17 & 4292 & 4328 & 8698 \\
\hline $1929 / 1930$ & & & & 4227 & 8876 \\
\hline $1930 / 1931$ & 16 & 16 & 4228 & 4261 & 8943 \\
\hline $1931 / 1932$ & 20 & 17 & 4248 & 4285 & 9028 \\
\hline $1932 / 1933$ & 13 & 15 & 4269 & 4297 & 9072 \\
\hline $1935 / 1936$ & 20 & 16 & 4468 & 4504 & 10195 \\
\hline $1936 / 1937$ & 29 & 27 & 4514 & 4570 & 11260 \\
\hline
\end{tabular}

\footnotetext{
${ }^{11}$ Az 1929/1930-1932/1933 közötti iskolaszám-csökkenés két okra vezethető vissza: A román Nemzeti-Liberális Párt kormányzását 1928-ban a Nemzeti Parasztpárt váltotta fel, amely a korábbi, intézményfejlesztési politikát eltúlzottnak tartotta. Ugyanakkor a beköszöntő világgazdasági válság és annak romániai hatásai további iskolák bezárását váltották ki. Az újabb növekedés Constantin Angelescu liberális párti tanügyminiszter második mandátuma alatt, 1933-at követően következett be (Livezeanu 1995: 39).
} 
A pár ezer állami elemi iskolába az 1920-as évek elején több mint 305000 diák, 15 évvel később pedig ennek közel kétszerese, 604000 tanuló iratkozott be. ${ }^{12} \mathrm{~A}$ beiratkozottaknak viszont egy jelentős része nem látogatta rendszeresen az iskolát. Az 1931/1932-es tanévben például a beiratkozottaknak csak 80,2\%-a járt ténylegesen iskolába. Ez az arány NagyRománia egyéb régióiban még rosszabb volt: Bukovinában $75,5 \%$, a Regátban $73,6 \%$, Besszarábiában $54,9 \%$, országos összesítésben pedig $72,3 \%$ (Anuarul Învățământului Primar 1933: IV).

1925-ig a statisztikák csak a román és a zsidó diákok számát tüntették fel, a többi nemzetiség az Egyéb kategóriában szerepelt, 1929/1930-ból pedig nem közöltek etnikai bontást. Mivel a magyar és a német kisebbségi gyermekek jelentős része egyházak által fenntartott vagy magániskolákba járt, az állami iskolákban az etnikai arányok a románok javára mozdultak el. 1925-ben például az iskolaköteles gyermekeknek 59,4\%-a volt román nemzetiségü, az állami iskolákban viszont 73,8\%-ot alkottak. Ezzel szemben 1925-ben a magyar elemisták aránya az állami intézményekben 17,4\% volt, holott az iskoláskorúak között 25\%-ot tettek ki. A németek esetében is jelentős eltérés mutatkozott, azaz 4,2 százalék a 9,4 százalékkal szemben. A zsidóság nem rendelkezett olyan fejlett iskolahálózattal, mint az előbb említett kisebbségek, habár a nagyobb településeken a hitközségek is müködtettek elemi iskolákat. Ennek tulajdonítható az, hogy az iskoláskorú zsidó gyermekek túlnyomó része az állami iskolákban tanult. 1925-ben például az iskoláskorúaknak és az állami elemi iskolák zsidó növendékeinek is 3,3\% volt az aránya. A későbbiekben változott ez a megoszlás és a magyarokhoz és németekhez hasonlóan a zsidók esetében is alulmaradt az állami intézményeket látogató elemisták aránya az iskolakötelesekétől: 1931-ben 3,1\%-ot tettek ki a zsidó iskolakötelesek, de az állami iskolákban csak 2,8\% volt. A többi diák vagy a városokban működő zsidó hitközségek által múködtetett elemikben tanult, vagy a kisebb települések, falvak különböző egyházai által fenntartott felekezeti intézményekben.

18. Az állami elemi iskolákba beiratkozott diákok etnikai megoszlása:

\begin{tabular}{|c|c|c|c|c|c|c|c|c|c|}
\hline & \multicolumn{2}{|c|}{ Román } & Német & Magyar & \multicolumn{2}{|c|}{ Zsidó } & \multicolumn{2}{|c|}{ Egyéb } & \multirow{2}{*}{$\begin{array}{c}\text { Össze- } \\
\text { sen }\end{array}$} \\
\hline & & $\%$ & $\%$ & $\%$ & & $\%$ & & $\%$ & \\
\hline $1921 / 1922$ & 181049 & 59,3 & & & 9832 & 3,2 & 114246 & 37,4 & 305127 \\
\hline $1922 / 1923$ & 205098 & 68,2 & & & 9334 & 3,1 & 86324 & 28,7 & 300754 \\
\hline $1923 / 1924$ & 214684 & 72,0 & & & 8703 & 2,9 & 74581 & 25,0 & 297968 \\
\hline $1924 / 1925$ & 239055 & 72,6 & & & 9265 & 2,8 & 81123 & 24,6 & 329443 \\
\hline
\end{tabular}

${ }^{12}$ Az 1921/1922-őt követő néhány évben csökkenés mutatható ki az elemi iskolások számát illetően. A csökkenés oka arra vezethető vissza, hogy az 1922/1923-1924/1925 közötti generáció a háború alatt született, amikor a születések száma alacsonyabb, a mortalitás pedig magasabb volt a békeidőkhöz képest. 


\begin{tabular}{|c|c|c|c|c|c|c|c|c|c|c|c|}
\hline $1925 / 1926$ & 242388 & 73,8 & 13959 & 4,2 & 57239 & 17,4 & 10762 & 3,3 & 4181 & 1,3 & 328529 \\
\hline $1926 / 1927$ & 254372 & 73,4 & 17057 & 4,9 & 57548 & 16,6 & 10833 & 3,1 & 6614 & 1,9 & 346424 \\
\hline $1927 / 1928$ & 283105 & 73,6 & 18171 & 4,7 & 64995 & 16,9 & 11522 & 3,0 & 7005 & 1,8 & 384798 \\
\hline $1928 / 1929$ & 313128 & 74,0 & 19924 & 4,7 & 69658 & 16,5 & 11974 & 2,8 & 8335 & 2,0 & 423019 \\
\hline $1929 / 1930$ & & & & & & & & & & & 460062 \\
\hline $1930 / 1931$ & 371014 & 73,4 & 27261 & 5,4 & 80221 & 15,9 & 13436 & 2,7 & 13457 & 2,7 & 505389 \\
\hline 1931/1932 & 390109 & 73,2 & 25429 & 4,8 & 90268 & 16,9 & 14863 & 2,8 & 12310 & 2,3 & 532979 \\
\hline $1932 / 1933$ & 419545 & 73,7 & 26045 & 4,6 & 96809 & 17,0 & 15466 & 2,7 & 11654 & 2,0 & 569519 \\
\hline $1935 / 1936$ & 455652 & 74,5 & 24201 & 4,0 & 102463 & 16,7 & 15350 & 2,5 & 14165 & 2,3 & 611831 \\
\hline $1936 / 1937$ & 4441443 & 73,0 & 25392 & 4,2 & 107464 & 17,8 & 15348 & 2,5 & 15162 & 2,5 & 604809 \\
\hline
\end{tabular}

A vallási megoszlást tekintve az etnikai bontáshoz hasonló eredményeket kapunk. Az állami iskolákban a túlnyomórészt román nemzetiségü görögkeleti és görög katolikus diákok aránya a két világháború között 70\% körül mozgott, a római katolikusoké 12-13, a reformátusoké 8-9, és az unitáriusoké pedig 1\% körül. Az evangélikusok aránya általában 1 százalék alatt maradt, míg az izraeliták 3\% körüli arányt alkottak.

19. Az állami elemi iskolák diákjainak felekezeti megoszlása:

\begin{tabular}{|c|c|c|c|c|c|c|c|c|c|}
\hline & 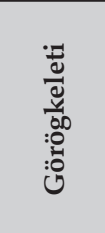 & 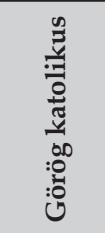 & 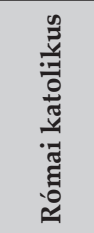 & 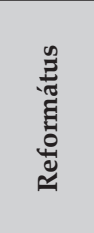 & & 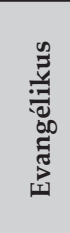 & 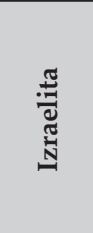 & 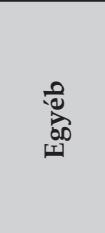 & 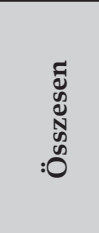 \\
\hline $1921 / 1922$ & 125974 & & & & & & 9832 & 169321 & 305127 \\
\hline $1922 / 1923$ & 134310 & & & & & & 9334 & 157110 & 300754 \\
\hline $1923 / 1924$ & 132657 & & & & & & 8703 & 156608 & 297968 \\
\hline $1924 / 1925$ & 143886 & & & & & & 9265 & 176292 & 329443 \\
\hline $1925 / 1926$ & 148685 & 94266 & 39335 & 28706 & 3798 & 2118 & 10762 & 859 & 328529 \\
\hline 1926/1927 & 143529 & 111152 & 42759 & 30539 & 3871 & 2851 & 10833 & 890 & 346424 \\
\hline $1927 / 1928$ & 162340 & 122111 & 46760 & 32970 & 4482 & 3342 & 11522 & 1271 & 384798 \\
\hline $1928 / 1929$ & 186687 & 126191 & 53058 & 35655 & 4346 & 3554 & 11974 & 1554 & 423019 \\
\hline $1930 / 1931$ & 243664 & 141622 & 50625 & 42750 & 5825 & 4454 & 13436 & 3013 & 505389 \\
\hline $1931 / 1932$ & 223630 & 167923 & 66385 & 45972 & 5915 & 4881 & 14863 & 3410 & 532979 \\
\hline $1932 / 1933$ & 248459 & 172189 & 67925 & 49785 & 6327 & 5062 & 15466 & 4306 & 569519 \\
\hline $1935 / 1936$ & 249812 & 194626 & 77359 & 54196 & 7565 & 8432 & 15350 & 4491 & 611831 \\
\hline $1936 / 1937$ & 246789 & 192679 & 80358 & 53387 & 6206 & 5022 & 15348 & 5020 & 604809 \\
\hline
\end{tabular}


20. Az állami elemi iskolák diákjainak felekezeti megoszlása százalékban kifejezve:

\begin{tabular}{|c|c|c|c|c|c|c|c|c|}
\hline & 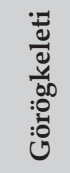 & 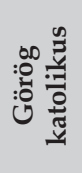 & 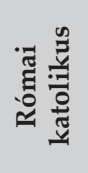 & 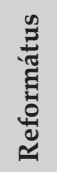 & 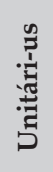 & 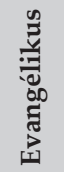 & 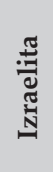 & 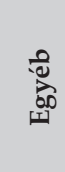 \\
\hline $1921 / 1922$ & 41,3 & & & & & & 3,2 & 55,5 \\
\hline $1922 / 1923$ & 44,7 & & & & & & 3,1 & 52,2 \\
\hline $1923 / 1924$ & 44,5 & & & & & & 2,9 & 52,6 \\
\hline $1924 / 1925$ & 43,7 & & & & & & 2,8 & 53,5 \\
\hline $1925 / 1926$ & 45,3 & 28,7 & 12,0 & 8,7 & 1,2 & 0,6 & 3,3 & 0,3 \\
\hline $1926 / 1927$ & 41,4 & 32,1 & 12,3 & 8,8 & 1,1 & 0,8 & 3,1 & 0,3 \\
\hline $1927 / 1928$ & 42,2 & 31,7 & 12,2 & 8,6 & 1,2 & 0,9 & 3,0 & 0,3 \\
\hline $1928 / 1929$ & 44,1 & 29,8 & 12,5 & 8,4 & 1,0 & 0,8 & 2,8 & 0,4 \\
\hline 1930/1931 & 48,2 & 28,0 & 10,0 & 8,5 & 1,2 & 0,9 & 2,7 & 0,6 \\
\hline 1931/1932 & 42,0 & 31,5 & 12,5 & 8,6 & 1,1 & 0,9 & 2,8 & 0,6 \\
\hline $1932 / 1933$ & 43,6 & 30,2 & 11,9 & 8,7 & 1,1 & 0,9 & 2,7 & 0,8 \\
\hline $1935 / 1936$ & 40,8 & 31,8 & 12,6 & 8,9 & 1,2 & 1,4 & 2,5 & 0,7 \\
\hline 1936/1937 & 40,8 & 31,9 & 13,3 & 8,8 & 1,0 & 0,8 & 2,5 & 0,8 \\
\hline
\end{tabular}

Az egyházi és magán elemi iskolákra nézve négy évből, 1927-1929 és 1935-1937-ből rendelkezünk kimutatásokkal. Ezekben az években 1200 körül mozgott az ilyen típusú intézmények száma, és szinte kivétel nélkül mindegyiket valamelyik egyház tartotta fenn. Látható, hogy 1920/1921-hez képest közel egyharmadára csökkent az egyházi iskolák száma, amely több okra is visszavezethető. 1918 után a román állam átvette a legtöbb görögkeleti és görög katolikus iskola kezelését, ezzel párhuzamosan pedig, 1923-1924 folyamán a kisebbségi felekezeti elemi oktatási intézmények százait zárták be különböző indokokkal (Bíró 2002: 354). Hasonló iskolabezárásokra került sor 1936-ban és 1937-ben is, főként a magyarok által lakott Székelyföldön (Bíró 2002: 356).

Figyelemre méltó az a tény, hogy nagyon sok iskola nem rendelkezett nyilvánossági joggal, amely fóleg a kisebbségi egyházak (római katolikusok, protestánsok, izraeliták) által fenntartott intézmények körüli problémáknak tulajdonítható. Az 1925-ös magánoktatási törvény ugyanis jelentős mértékben megnehezítette a nyilvánossági jog megszerzését az egyházi és más jellegű magániskolák számára. Az egyik ilyen akadály a képesítéssel rendelkező tanerők számának a megszabása volt. A törvény az állami iskolák esetében nem írt elő erre nézve semmilyen kötelezettséget. Ezzel szemben a magán elemi iskolák csak akkor kaptak nyilvánossági jogot, ha legalább egy végleges tanító állt az alkalmazásukban. A magán középisko- 
lák alsó tagozata részére már kettő, míg a felső tagozatok részére legalább négy végleges tanárt írt elő a törvény. A nyilvánossági jog birtoklása többek között jogot adott az illető intézménynek államérvényes bizonyítványok kiállítására. Ellenkező esetben ezeknek az iskoláknak a növendékei magántanulói minőségben állami iskolákban kellett, hogy vizsgázzanak és bizonyítványt szerezzenek (Nagy 1944: 136-137).

21. Egyházi és magán elemi iskolák Erdélyben:

\begin{tabular}{|c|c|c|c|c|c|c|c|c|c|}
\hline & \multicolumn{4}{|c|}{ Intézmény típusa } & \multicolumn{3}{|c|}{ Iskolafenntartó } & \multicolumn{2}{|c|}{ Működés } \\
\hline & 浔 & స్త్త & 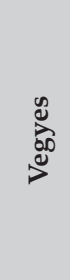 & 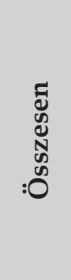 & 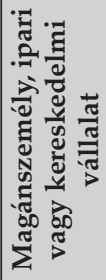 & 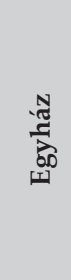 & 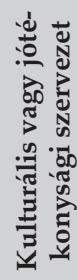 & 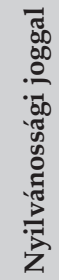 & 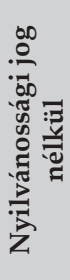 \\
\hline $1927 / 1928$ & 29 & 39 & 1142 & 1210 & & & & & \\
\hline $1928 / 1929$ & 27 & 41 & 1166 & 1234 & & & & & \\
\hline $1935 / 1936$ & 30 & 37 & 1124 & 1191 & 3 & 1185 & 3 & 950 & 241 \\
\hline $1936 / 1937$ & 26 & 36 & 1120 & 1182 & 2 & 1179 & 1 & 975 & 207 \\
\hline
\end{tabular}

A nem állami iskolák növendékeinek túlnyomó többsége valamely nemzeti kisebbséghez tartozott, a románok aránya a vizsgált években nem érte el az egy százalékot sem. Ezzel szemben a magyarok aránya 51-58\% között, a németeké 32-40\% és a zsidóké 3-4\% között mozgott. Összehasonlítva az állami iskolákba járó kisebbségi diákok számával azt látjuk, hogy a magyaroknak 1927/1928-ban 46,3\%-a, a zsidóknak pedig 33,7\%-a járt egyházi vagy egyéb magánjellegű iskolába, és 53,7, illetve 66,3\%-uk állami intézménybe. A németeknél ez az arány 1927/1928-ban fordított, azaz 63,3, illetve 36,7 volt. Mivel az egyházi és magánjellegú iskolákat általában a működtetők saját anyagi forrásból finanszírozták, és csak minimális és rendszertelen állami támogatásban részesültek, elmondható, hogy a kisebbségi gyermekek közel felének az elemi iskolai szintű oktatását a kisebbségi egyházak fedezték anyagilag.

22. Az egyházi és magánjellegü iskolákba beiratkozott diákok nemzetisége:

\begin{tabular}{|c|c|c|c|c|c|c|c|c|c|c|c|c|}
\hline & \multicolumn{11}{|c|}{ Beiratkozott diákok nemzetisége } & \multirow{3}{*}{ Tanerök } \\
\hline & \multicolumn{2}{|c|}{ Román } & \multicolumn{2}{|c|}{ Német } & \multicolumn{2}{|c|}{ Magyar } & \multicolumn{2}{|c|}{ Zsidó } & \multicolumn{2}{|c|}{ Egyéb } & \multirow[t]{2}{*}{$\begin{array}{l}\text { Össze- } \\
\text { sen }\end{array}$} & \\
\hline & & $\%$ & & $\%$ & & $\%$ & & $\%$ & & $\%$ & & \\
\hline 1927/1928 & 438 & 0,5 & 31403 & 32,8 & 55964 & 58,5 & 3888 & 4,1 & 3993 & 4,2 & 95686 & 2407 \\
\hline 1928/1929 & 987 & 0,9 & 35717 & 32,9 & 63792 & 58,8 & 4487 & 4,1 & 3517 & 3,2 & 108500 & 2455 \\
\hline 1935/1936 & 362 & 0,3 & 41155 & 37,0 & 60495 & 54,4 & 3482 & 3,1 & 5718 & 5,1 & 111212 & 2521 \\
\hline 1936/1937 & 331 & 0,3 & 46067 & 40,2 & 59356 & 51,8 & 3428 & 3,0 & 5353 & 4,7 & 114535 & 2597 \\
\hline
\end{tabular}


Az egyházi és egyéb magánjellegű elemi iskolába járó tanulók etnikai megoszlásához hasonlóan a vallási megoszlás is a kisebbségi egyházak dominanciáját mutatja. 1927/1928-ban a diákok 34,6\%-a volt római katolikus, $33,9 \%$-a református, 21,9\%-a evangélikus, 4,1\%-a izraelita és 2,3\%-a unitárius. Az Egyéb kategóriába tartozó mohamedánok és baptisták aránya nem volt mérhető, és a későbbi években is alig érték el a 0,1-0,2\%-ot.

23. Az egyházi és magán elemi iskolákba beiratkozott diákok felekezeti megoszlása:

\begin{tabular}{|c|c|c|c|c|c|c|c|c|c|}
\hline & \multicolumn{9}{|c|}{ A beiratkozottak vallása } \\
\hline & 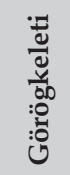 & 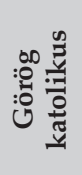 & 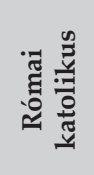 & 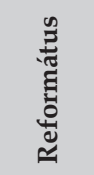 & & 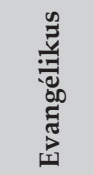 & & $\underset{\text { क्ञ }}{\stackrel{0}{\otimes}}$ & 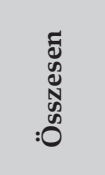 \\
\hline $1926 / 1927$ & 2759 & 421 & 25978 & 30734 & 2036 & 23796 & 3659 & 38 & 89421 \\
\hline $1927 / 1928$ & 2646 & 318 & 33069 & 32468 & 2243 & 20931 & 3965 & 46 & 95686 \\
\hline $1928 / 1929$ & 3243 & 514 & 35825 & 34953 & 5590 & 23831 & 4487 & 57 & 108500 \\
\hline $1935 / 1936$ & 4956 & 171 & 33110 & 35895 & 2422 & 30993 & 3482 & 183 & 111212 \\
\hline $1936 / 1937$ & 4825 & 145 & 33067 & 35118 & 2280 & 35508 & 3428 & 164 & 114535 \\
\hline
\end{tabular}

24. Az egyházi és magán elemi iskolákba beiratkozott diákok felekezeti megoszlása, százalékban kifejezve:

\begin{tabular}{|c|c|c|c|c|c|c|c|c|}
\hline & \multicolumn{8}{|c|}{ A beiratkozottak vallása } \\
\hline & 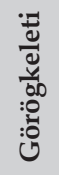 & 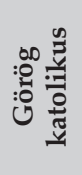 & 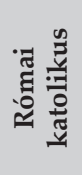 & 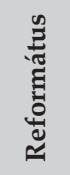 & & 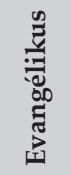 & 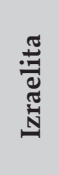 & 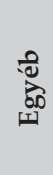 \\
\hline $1926 / 1927$ & 3,1 & 0,5 & 29,1 & 34,4 & 2,3 & 26,6 & 4,1 & 0,0 \\
\hline $1927 / 1928$ & 2,8 & 0,3 & 34,6 & 33,9 & 2,3 & 21,9 & 4,1 & 0,0 \\
\hline 1928/1929 & 3,0 & 0,5 & 33,0 & 32,2 & 5,2 & 22,0 & 4,1 & 0,1 \\
\hline $1935 / 1936$ & 4,5 & 0,2 & 29,8 & 32,3 & 2,2 & 27,9 & 3,1 & 0,2 \\
\hline $1936 / 1937$ & 4,2 & 0,1 & 28,9 & 30,7 & 2,0 & 31,0 & 3,0 & 0,1 \\
\hline
\end{tabular}

Amint már jeleztük, az állami fenntartású elemi iskolák száma az intenzív infrastruktúra-fejlesztésnek köszönhetően a két világháború között jelentős mértékben megugrott, miközben az egyháziaké csökkent. Ennek eredményeként az 1920/1921-es 32,7\%-os arányról az állami iskolák részesedése 79,5\%-ra emelkedett. Hasonlóan drasztikus változás figyelhető meg a diákok esetében is. 1920/1921-ben a diákoknak 40,2\%-a járt állami elemi iskolába, és 59,8\%-uk egyháziba. 1936/1937-re már 84,1\% volt az állami elemisták aránya. 
25. Az erdélyi elemi iskolák megoszlása fenntartók szerint és a diákok aránya:

\begin{tabular}{|c|c|c|c|c|}
\hline \multirow{2}{*}{} & \multicolumn{2}{|c|}{ Iskolák aránya } & \multicolumn{2}{c|}{ Diákok aránya } \\
\cline { 2 - 5 } & $\begin{array}{c}\text { Állami és } \\
\text { községi }\end{array}$ & $\begin{array}{c}\text { Egyházi és } \\
\text { magán }\end{array}$ & $\begin{array}{c}\text { Állami és } \\
\text { községi }\end{array}$ & $\begin{array}{c}\text { Egyházi és } \\
\text { magán }\end{array}$ \\
\hline $\mathbf{1 9 2 0 / 1 9 2 1}$ & 32,7 & 67,3 & 40,2 & 59,8 \\
\hline $\mathbf{1 9 2 7 / 1 9 2 8}$ & 76,1 & 23,9 & 80,1 & 19,9 \\
\hline $\mathbf{1 9 2 8 / 1 9 2 9}$ & 77,8 & 22,2 & 79,6 & 20,4 \\
\hline $\mathbf{1 9 3 5 / 1 9 3 6}$ & 79,1 & 20,9 & 84,6 & 15,4 \\
\hline $\mathbf{1 9 3 6 / 1 9 3 7}$ & 79,5 & 20,5 & 84,1 & 15,9 \\
\hline
\end{tabular}

A fenti adatok arról árulkodnak, hogy a román állam expanzív iskolapolitikája sikeresnek bizonyult. Mindeközben az egy iskolára eső diákok száma továbbra is az egyházi intézményekben volt alacsonyabb, amely azt jelzi, hogy az egyházi struktúrákat nem sikerült teljes mértékben elsorvasztani. Ugyanakkor az is nyilvánvaló, hogy az egyházi intézményrendszernek teljes egészében nemzeti kisebbségi jellege volt. A román elemista diákoknak csak 0,3\%-a járt felekezeti iskolába 1927/1928-ban. Ezzel szemben a zsidó tanulóknak 27,3\%-a, a magyaroknak 47,8, a németeknek pedig 64,2\%-a frekventálta az egyházi intézményeket. Magyarázatra szorul az egyes kisebbségek eltérő arányszáma. A fóként városi zsidó népesség kevesebb saját iskolát tartott fent, gyermekeiket általában állami intézménybe küldték. Ez egyébként annak is volt a következménye, hogy az 1925-ös magánoktatási törvényt követően a zsidó diákok egyre nehezebben nyertek felvételt a más felekezetek által fenntartott iskolákba (A törvény előtt, 1920/1921-ben a zsidó diákoknak 55,4\%-a járt egyházi elemibe) (Statistica învățământului 1924: 441). A magyarok esetében a folyamatosan zsugorodó egyházi iskolahálózat váltotta ki a diákok állami iskolába vándorlását. A németek által élvezett viszonylagos immunitás, illetve a nagyon erős intézményi, társadalmi szervezettség a saját iskolahálózat megmaradását eredményezte.

Felekezeti bontásban hasonló megoszlást tapasztalunk. Az elemista gyermekek túlnyomó többségét alkotó ortodox és görög katolikus diákoknak összesen 2,1\%-a járt felekezeti intézménybe 1928/1929-ben. Az izraelita diákoknál ez az arány 27,3 százalék, a római katolikusoknál 40,3, a reformátusoknál 49,5, az unitáriusoknál 56,3, a főként német nemzetiségű evangélikusoknál viszont $87 \%$ volt. 


\subsection{Középfokú oktatás}

\subsubsection{Tanítóképzők}

A korabeli román statisztikák a középfokú oktatást nyújtó tanintézményeket több típusra osztották. Az alábbiakban ezt a felosztást követjük.

Az elemi oktatásban dolgozó pedagógusok felkészítését tanítóképzők látták el. A két világháború között Erdélyben 30 alatt volt azoknak az állami intézményeknek a száma, amelyek tanítókat vagy tanítónőket képeztek. Az évek során fokozatos növekedést figyelhetünk meg mind az intézmények, mind a növendékek és a tanszemélyzet számának tekintetében. Amennyiben a beiratkozottak és a felsőbb osztályba továbblépő diákok számát vizsgáljuk, az látható, hogy a lemorzsolódás aránya 12-15\% között mozgott ebben az időszakban (lásd még a 6. sz. mellékletet).

26. Az erdélyi állami tanitó- és tanitónőképző iskolák diákjai és tanárai:

\begin{tabular}{|c|c|c|c|c|c|}
\hline \multirow[b]{3}{*}{$1921 / 1922$} & \multirow{3}{*}{$\begin{array}{c}\begin{array}{c}\text { Iskolák } \\
\text { száma }\end{array} \\
16 \\
\end{array}$} & \multicolumn{3}{|c|}{ Tanulók } & \multirow{3}{*}{$\begin{array}{c}\begin{array}{c}\text { Tanárok } \\
\text { (mesterek nélkül) }\end{array} \\
148 \\
\end{array}$} \\
\hline & & \multirow{2}{*}{$\begin{array}{c}\text { Beiratkozottak } \\
2766 \\
\end{array}$} & \multicolumn{2}{|c|}{$\begin{array}{c}\text { Felsőbb osztályba } \\
\text { léptek }\end{array}$} & \\
\hline & & & 2389 & 86,4 & \\
\hline $1922 / 1923$ & 17 & 3475 & 2950 & 84,9 & 158 \\
\hline $1923 / 1924$ & 22 & 4145 & 3639 & 87,8 & 198 \\
\hline $1924 / 1925$ & 25 & 4927 & 4293 & 87,1 & 234 \\
\hline $1925 / 1926$ & 25 & 5308 & 4530 & 85,3 & 234 \\
\hline $1926 / 1927$ & 25 & 5529 & 4756 & 86,0 & 256 \\
\hline $1927 / 1928$ & 30 & 6526 & 5592 & 85,7 & 291 \\
\hline $1928 / 1929$ & 30 & 6337 & 5514 & 87,0 & 317 \\
\hline $1930 / 1931$ & 29 & 5185 & 4459 & 86,0 & 374 \\
\hline $1931 / 1932$ & 28 & 4449 & 3987 & 89,6 & 470 \\
\hline $1932 / 1933$ & 25 & 3811 & 3403 & 89,3 & 412 \\
\hline $1935 / 1936$ & 25 & 4726 & 4115 & 87,1 & 433 \\
\hline $1936 / 1937$ & 26 & 4860 & 4266 & 87,8 & 445 \\
\hline
\end{tabular}

Az állami tanítóképzők és tanítónőképzők diákjai szinte kizárólag a román etnikumúak közül kerültek ki. Azokban a két világháború közötti években, amelyekre nézve nemzetiségi adatokkal is rendelkezünk, ezeknek az intézményeknek a falai között tanuló diákoknak több mint kilencven százaléka volt román. Őket a magyarok követték néhány százalékkal, a németeké pedig csak egy-két esetben lépte túl az egyszázalékos arányt. A zsidó növendékek aránya minden esetben egy százalék alatt maradt (lásd még a 7. sz. mellékletet). 
27. Az állami tanitó- és tanitónőképzók diákjainak nemzetiségi megoszlása:

\begin{tabular}{|c|c|c|c|c|c|c|c|c|c|c|c|}
\hline & \multicolumn{11}{|c|}{ A beiratkozott diákok nemzetisége } \\
\hline & \multicolumn{2}{|c|}{ Román } & \multicolumn{2}{|c|}{ Német } & \multicolumn{2}{|c|}{ Magyar } & \multicolumn{2}{|c|}{ Zsidó } & \multicolumn{2}{|c|}{ Egyéb } & \multirow[t]{2}{*}{ Összesen } \\
\hline & & $\%$ & & $\%$ & & $\%$ & & $\%$ & & $\%$ & \\
\hline $1923 / 1924$ & 3933 & 94,9 & 11 & 0,3 & 189 & 4,6 & 9 & 0,2 & 3 & 0,1 & 4145 \\
\hline $1924 / 1925$ & 4672 & 94,8 & 35 & 0,7 & 199 & 4,0 & 14 & 0,3 & 7 & 0,1 & 4927 \\
\hline $1925 / 1926$ & 5078 & 95,7 & 34 & 0,6 & 149 & 2,8 & 12 & 0,2 & 35 & 0,7 & 5308 \\
\hline $1926 / 1927$ & 5339 & 96,6 & 28 & 0,5 & 125 & 2,3 & 11 & 0,2 & 26 & 0,5 & 5529 \\
\hline $1927 / 1928$ & 6279 & 96,2 & 24 & 0,4 & 177 & 2,7 & 12 & 0,2 & 34 & 0,5 & 6526 \\
\hline 1928/1929 & 6102 & 96,3 & 45 & 0,7 & 142 & 2,2 & 11 & 0,2 & 37 & 0,6 & 6337 \\
\hline $1935 / 1936$ & 4394 & 93,0 & 58 & 1,2 & 202 & 4,3 & 17 & 0,4 & 55 & 1,2 & 4726 \\
\hline $1936 / 1937$ & 4526 & 93,1 & 79 & 1,6 & 188 & 3,9 & 9 & 0,2 & 58 & 1,2 & 4860 \\
\hline
\end{tabular}

Felekezeti szempontból a túlnyomórészt románajkú görögkeletiek és görög katolikusok alkották a többséget. A római katolikusok, protestánsok és izraeliták összesen alig tettek ki néhány százalékot (lásd még a 8-9. sz. mellékleteket).

28. Az erdélyi állami tanitó- és tanitónóképzők diákjainak vallási megoszlása:

\begin{tabular}{|c|c|c|c|c|c|c|c|c|c|}
\hline & \multicolumn{9}{|c|}{ A beiratkozottak vallása } \\
\hline & 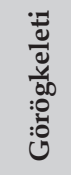 & 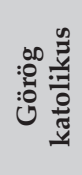 & 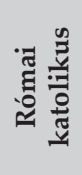 & 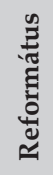 & 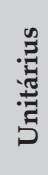 & 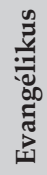 & 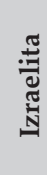 & 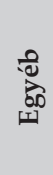 & 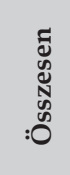 \\
\hline $1923 / 1924$ & 2825 & 1088 & 101 & 76 & 34 & 11 & 9 & 1 & 4145 \\
\hline $1924 / 1925$ & 3475 & 1183 & 125 & 78 & 39 & 10 & 14 & 3 & 4927 \\
\hline $1925 / 1926$ & 3774 & 1319 & 99 & 69 & 27 & 5 & 12 & 3 & 5308 \\
\hline $1926 / 1927$ & 4012 & 1332 & 95 & 51 & 21 & 6 & 11 & 1 & 5529 \\
\hline $1927 / 1928$ & 4366 & 1931 & 112 & 68 & 23 & 10 & 12 & 4 & 6526 \\
\hline 1928/1929 & 4181 & 1937 & 115 & 71 & 17 & 2 & 11 & 3 & 6337 \\
\hline 1930/1931 & 3086 & 1830 & 188 & 61 & 17 & 12 & 8 & 1 & 5185 \\
\hline 1931/1932 & 2761 & 1468 & 132 & 44 & 20 & 14 & 10 & - & 4449 \\
\hline $1932 / 1933$ & 2360 & 1203 & 135 & 66 & 17 & 18 & 12 & - & 3811 \\
\hline $1935 / 1936$ & 2719 & 1683 & 175 & 80 & 34 & 14 & 19 & 2 & 4726 \\
\hline $1936 / 1937$ & 2761 & 1784 & 177 & 78 & 26 & 16 & 7 & 11 & 4860 \\
\hline
\end{tabular}


29. Az erdélyi állami tanító- és tanitónóképzók diákjainak vallási megoszlása, százalékban kifejezve:

\begin{tabular}{|c|c|c|c|c|c|c|c|}
\hline & \multicolumn{7}{|c|}{ A beiratkozottak vallása } \\
\hline & 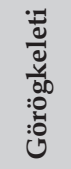 & 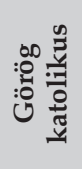 & 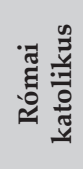 & 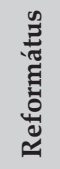 & 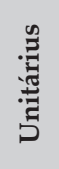 & 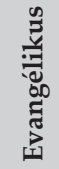 & 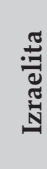 \\
\hline $1923 / 1924$ & 68,2 & 26,2 & 2,4 & 1,8 & 0,8 & 0,3 & 0,2 \\
\hline $1924 / 1925$ & 70,5 & 24,0 & 2,5 & 1,6 & 0,8 & 0,2 & 0,3 \\
\hline $1925 / 1926$ & 71,1 & 24,8 & 1,9 & 1,3 & 0,5 & 0,1 & 0,2 \\
\hline $1926 / 1927$ & 72,6 & 24,1 & 1,7 & 0,9 & 0,4 & 0,1 & 0,2 \\
\hline $1927 / 1928$ & 66,9 & 29,6 & 1,7 & 1,0 & 0,4 & 0,2 & 0,2 \\
\hline $1928 / 1929$ & 66,0 & 30,6 & 1,8 & 1,1 & 0,3 & 0,0 & 0,2 \\
\hline $1930 / 1931$ & 59,5 & 35,3 & 3,6 & 1,2 & 0,3 & 0,2 & 0,2 \\
\hline 1931/1932 & 62,1 & 33,0 & 3,0 & 1,0 & 0,4 & 0,3 & 0,2 \\
\hline $1932 / 1933$ & 61,9 & 31,6 & 3,5 & 1,7 & 0,4 & 0,5 & 0,3 \\
\hline $1935 / 1936$ & 57,5 & 35,6 & 3,7 & 1,7 & 0,7 & 0,3 & 0,4 \\
\hline $1936 / 1937$ & 56,8 & 36,7 & 3,6 & 1,6 & 0,5 & 0,3 & 0,1 \\
\hline
\end{tabular}

Amíg az állami intézményekbe túlnyomórészt román diákok jártak, addig az egyházi és más magánjellegű tanító-, illetve tanítónőképzőkben elsősorban kisebbségi diákok tanultak. A magyar és a német kisebbség ilyen úton próbálta megoldani a saját, anyanyelvi oktatással megvalósuló pedagógus-utánpótlást. Erre nézve az 1926-1928 közötti tanévekre rendelkezünk adatokkal. Ezekben az években 12-13 egyházi tanítóképző müködött Erdélyben és az éves diákszám ezer körül mozgott. A felsőbb osztályba lépők aránya nyolcvankilenc százalék körül volt. Habár a diáklétszám fokozatosan növekedett az évek során, a tanárok száma 150-ről 128-ra esett vissza 1926/1927-hez képest.

Az iskolafenntartók megoszlását tekintve az 1926/1927-es tanévben a 13 oktatási intézményből egyet a görög katolikus, hetet a római katolikus, kettőt a református és négyet az evangélikus egyház tartott fenn. A következő évtől a görög katolikus tanítónőképző megszűnt, így csak 12 intézmény folytatta a müködését (lásd még a 10. sz. mellékletet).

30. Az egyházi és egyesületi tanitóképzók diákjai és tanárai:

\begin{tabular}{|c|c|c|c|c|c|}
\hline & $\begin{array}{c}\text { Intézmények } \\
\text { száma }\end{array}$ & $\begin{array}{c}\text { Beiratkozott } \\
\text { diákok }\end{array}$ & \multicolumn{2}{|c|}{ Felsőbb osztályba léptek } & Tanerők \\
\hline $\mathbf{1 9 2 6 / 1 9 2 7}$ & 13 & 908 & 811 & 89,3 & 150 \\
\hline $\mathbf{1 9 2 7 / 1 9 2 8}$ & 12 & 954 & 848 & 88,9 & 128 \\
\hline $\mathbf{1 9 2 8 / 1 9 2 9}$ & 12 & 1114 & 980 & 88,0 & 128 \\
\hline
\end{tabular}


Az egyházi tanítóképző intézetek növendékei a magyar és német kisebbségek köréből verbuválódtak. Ez alól csupán az 1926/1927-es tanév képez kivételt, ekkor ugyanis a még működő görög katolikus tanítónőképző román diákjai 19,8 százalékot tettek ki.

31. Az egyházi és egyesületi tanítóképzők diákjainak nemzetiségi megoszlása:

\begin{tabular}{|c|c|c|c|c|c|c|c|c|c|c|}
\hline & \multicolumn{10}{|c|}{ Beiratkozott diákok nemzetisége } \\
\hline & \multicolumn{2}{|c|}{ Román } & \multicolumn{2}{|c|}{ Német } & \multicolumn{2}{|c|}{ Magyar } & \multicolumn{2}{|c|}{ Zsidó } & \multirow{2}{*}{ Egyéb } & \multirow{2}{*}{ Összesen } \\
\hline & & $\%$ & & $\%$ & & $\%$ & & $\%$ & & \\
\hline $1926 / 1927$ & 119 & 13,1 & 318 & 35,0 & 465 & 51,2 & - & - & 6 & 908 \\
\hline $1927 / 1928$ & - & - & 339 & 35,5 & 613 & 64,3 & - & - & 2 & 954 \\
\hline $1928 / 1929$ & - & - & 343 & 30,8 & 768 & 68,9 & 3 & 0,3 & - & 1114 \\
\hline
\end{tabular}

A nemzetiségi arányoknak megfelelően a legtöbb diák római katolikus, evangélikus és református volt. Görögkeletiek és görög katolikusok csak az 1926/1927-es tanévben mutathatóak ki. Az unitáriusok és izraeliták száma szintén elenyésző volt.

32. Az egyházi és egyesületi tanitóképzők diákjainak felekezeti megoszlása:

\begin{tabular}{|c|c|c|c|c|c|c|c|c|c|}
\hline & \multicolumn{9}{|c|}{ Beiratkozottak vallása } \\
\hline & 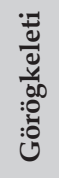 & 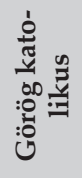 & 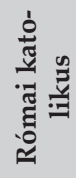 & 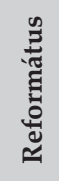 & & 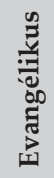 & 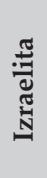 & $\overbrace{\overrightarrow{10}}^{00}$ & 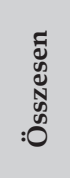 \\
\hline $1926 / 1927$ & 12 & 109 & 314 & 220 & 10 & 238 & 2 & 3 & 908 \\
\hline $1927 / 1928$ & - & - & 398 & 291 & 22 & 243 & - & - & 954 \\
\hline $1928 / 1929$ & - & - & 491 & 353 & 25 & 242 & 3 & - & 1114 \\
\hline
\end{tabular}

33. Az egyházi és egyesületi tanítóképzók diákjainak felekezeti megoszlása, százalékban kifejezve:

\begin{tabular}{|c|c|c|c|c|c|c|c|}
\hline & \multicolumn{7}{|c|}{ Beiratkozottak vallása } \\
\hline & 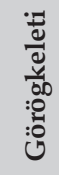 & 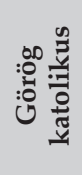 & 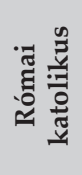 & 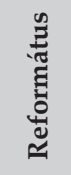 & & 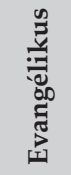 & 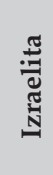 \\
\hline $1926 / 1927$ & 1,3 & 12,0 & 34,6 & 24,2 & 1,1 & 26,2 & 0,2 \\
\hline $1927 / 1928$ & - & - & 41,7 & 30,5 & 2,3 & 25,5 & - \\
\hline $1928 / 1929$ & - & - & 44,1 & 31,7 & 2,2 & 21,7 & 0,3 \\
\hline
\end{tabular}

Az állami és egyházi tanítóképzők diákjainak nemzetiségi adatait együttesen vizsgálva az derül ki, hogy a kisebbségek pedagógus-utánképzése messze alulmaradt a normálisnál, amely hosszú távon a már amúgy 
is létező tanítóhiány állandósulásával, illetve mélyülésével fenyegetett. Ez legjobban a zsidóknál nyilvánult meg, akik a növendékek között csak $0,2 \%$-ot alkottak. Az ő esetükben még egy fontos vetülete volt a jelenségnek. Amint az elemisták esetében, a tanítóképzős, középiskolás zsidó diákok többsége általában román tanítási nyelvű állami iskolákba járt. Amennyiben az állami oktatási rendszert egyfajta integrációs, asszimilációs csatornaként fogjuk fel, akkor az egyébként többségében magyar kulturális családi háttérrel rendelkező zsidó diákok egyre nagyobb körében ment végbe a magyar kultúrától való fokozatos eltávolodás.

\subsubsection{Polgári iskolák}

A polgári iskolák rendszerét az erdélyi oktatási intézményrendszer az Osztrák-Magyar Monarchia korából örökölte. Ez az iskolatípus az új román tanügyi törvénykezés következtében az 1920-as évek második felére megszünt. A négyosztályos polgári iskolák lényegében az elemi és a gimnáziumi oktatás között képeztek átmenetet. A polgári iskolák számára, tanerőire és diákjaira nézve az 1919/1920-as és az 1921/1922-1927/1928-as tanévekből rendelkezünk adatokkal.

Az 1919/1920-as tanévben Erdély területén összesen 115 polgári iskola müködött. Ezek közül 49 volt állami, 11 községi fenntartású és 55 egyházi jellegü. Az egyházi intézményekből a római katolikusok harmincat, a reformátusok tizenhármat, az unitáriusok kettőt, az evangélikusok nyolcat és az izraeliták kettőt müködtettek. A tanerők közel felét foglalkoztatták az egyházi iskolák, közel egyharmadukat az állami fenntartásúak és egy kisebb részüket a községi polgárik.

34. Polgári iskolák Erdélyben 1919/1920-ban:

\begin{tabular}{|l|l|c|c|c|c|c|c|}
\hline \multirow{2}{*}{} & \multicolumn{3}{|c|}{ Iskolák száma } & \multicolumn{3}{c|}{ Tanerök } \\
\cline { 3 - 8 } & Fiú & Lány & Összesen & $\begin{array}{c}\text { Fiú } \\
\text { iskolák }\end{array}$ & $\begin{array}{c}\text { Lány } \\
\text { iskolák }\end{array}$ & Összesen \\
\hline Állami & 25 & 24 & 49 & 252 & 240 & 492 \\
\hline \multirow{4}{*}{ Községi } & 5 & 6 & 11 & 74 & 65 & 139 \\
\hline \multirow{5}{*}{ Egyházi } & Római katolikus & 7 & 23 & 30 & 63 & 226 & 289 \\
\cline { 2 - 8 } & Református & 5 & 8 & 13 & 50 & 93 & 143 \\
\cline { 2 - 8 } & Unitárius & 2 & - & 2 & 24 & - & 24 \\
\cline { 2 - 8 } & Evangélikus & 3 & 5 & 8 & 31 & 64 & 95 \\
\cline { 2 - 8 } & Izraelita & 1 & 1 & 2 & 10 & 11 & 21 \\
\cline { 2 - 8 } & Összes egyházi & 18 & 37 & 55 & 178 & 394 & 572 \\
\hline \multicolumn{2}{|l|}{ Összesen } & 48 & 67 & 115 & 504 & 699 & 1203 \\
\hline
\end{tabular}


Amint a nemzetiségi adatokból is kitűnik, a polgári iskolákat elsősorban a kisebbségek látogatták és a román tanulók csupán az állami fenntartású intézményekben alkottak többséget. Az állam által müködtetett polgári iskolákban viszont az etnikai arányok többé-kevésbé megfeleltek Erdély etnikai viszonyainak. Ez alól csak a zsidók alkottak kivételt, akik, ahogy egyébként általánosan az iskolázottsági szintjüket tekintve is, felülreprezentáltak voltak a tanulók között.

35. A polgári iskolák diákjainak nemzetiségi megoszlása 1919/1920-ban:

\begin{tabular}{|c|c|c|c|c|c|c|c|c|c|c|c|c|}
\hline & \multicolumn{11}{|c|}{ Beiratkozott diákok nemzetisége } \\
\hline & & \multicolumn{2}{|c|}{ Román } & \multicolumn{2}{|c|}{ Német } & \multicolumn{2}{|c|}{ Magyar } & \multicolumn{2}{|c|}{ Zsidó } & \multicolumn{2}{|c|}{ Egyéb } & \multirow{2}{*}{$\begin{array}{c}\text { Össze- } \\
\text { sen }\end{array}$} \\
\hline & & & $\%$ & & $\%$ & & $\%$ & & $\%$ & & $\%$ & \\
\hline \multicolumn{2}{|l|}{ Állami } & 3721 & 60,3 & 569 & 9,2 & 1350 & 21,9 & 460 & 7,5 & 73 & 1,2 & 6173 \\
\hline \multicolumn{2}{|l|}{ Községi } & 309 & 9,5 & 379 & 11,6 & 2099 & 64,3 & 444 & 13,6 & 32 & 1,0 & 3263 \\
\hline \multirow{6}{*}{ Egyházi } & \begin{tabular}{|l|} 
Római \\
katolikus
\end{tabular} & 286 & 5,2 & 859 & 15,7 & 3875 & 70,9 & 197 & 3,6 & 246 & 4,5 & 5463 \\
\hline & Református & 18 & 0,8 & 33 & 1,5 & 1757 & 80,7 & 370 & 17,0 & - & - & 2178 \\
\hline & Unitárius & 3 & 1,7 & 4 & 2,2 & 157 & 87,7 & 15 & 8,4 & - & - & 179 \\
\hline & Lutheránus & 21 & 1,4 & 958 & 66,0 & 348 & 24,0 & 125 & 8,6 & - & - & 1452 \\
\hline & \begin{tabular}{|l|} 
Izraelita \\
\end{tabular} & 2 & 0,6 & - & - & 5 & \begin{tabular}{|l|}
1,4 \\
\end{tabular} & 338 & 98,0 & - & - & 345 \\
\hline & \begin{tabular}{|l|} 
Összes \\
egyházi
\end{tabular} & 330 & 3,4 & 1854 & 19,3 & 6142 & 63,9 & 1045 & 10,9 & 246 & 2,6 & 9617 \\
\hline \multicolumn{2}{|c|}{ Összesen } & 4360 & 22,9 & 2802 & 14,7 & 9591 & 50,3 & 1949 & 10,2 & 351 & 1,8 & 19053 \\
\hline
\end{tabular}

A következő években a polgári iskolák és azok tanulóinak, tanárainak száma fokozatosan csökkent. Az állam által fenntartott ilyen jellegü intézményekből 1921-ben még 72 müködött, 1927-ben viszont csak 27. Azt követően pedig megszűnt a polgári iskolák rendszere.

36. Állami fenntartású polgári iskolák Erdélyben:

\begin{tabular}{|c|c|c|c|c|c|c|c|}
\hline & \multicolumn{4}{|c|}{ Iskolák száma } & \multicolumn{2}{|c|}{ Tanulók } & \multirow[b]{2}{*}{$\begin{array}{c}\text { Tanárok } \\
\text { (mesterek } \\
\text { nélkül) }\end{array}$} \\
\hline & Fiú & Lány & Vegyes & Összesen & Beiratkozottak & $\begin{array}{c}\text { Felsőbb } \\
\text { osztályba } \\
\text { léptek }\end{array}$ & \\
\hline $1921 / 1922$ & 26 & 35 & 11 & 72 & 11022 & 9070 & 523 \\
\hline $1922 / 1923$ & 32 & 38 & 7 & 77 & 11647 & 9207 & 504 \\
\hline 1923/1924 & 22 & 27 & 4 & 53 & 9008 & 7417 & 360 \\
\hline $1924 / 1925$ & 19 & 29 & 2 & 50 & 8023 & 6620 & 350 \\
\hline $1925 / 1926$ & 18 & 29 & 1 & 48 & 7641 & 6132 & 318 \\
\hline $1926 / 1927$ & 16 & 16 & 1 & 33 & 5052 & 4149 & 226 \\
\hline $1927 / 1928$ & 12 & 14 & 1 & 27 & 3423 & 2824 & 174 \\
\hline
\end{tabular}


A tanulók nemzetiségi és felekezeti összetételét tekintve is jelentős átalakulásokat figyelhetünk meg. A román diákok aránya ugyanis fokozatosan nőtt, míg a zsidóké csökkent az évek során. A magyar és német növendékek aránya megközelítőleg hasonló maradt.

37. Az állami fenntartású polgári iskolák diákjainak nemzetiségi megoszlása:

\begin{tabular}{|c|c|c|c|c|c|c|c|c|c|c|c|}
\hline & \multicolumn{10}{|c|}{ Beiratkozottak nemzetisége } & \multirow{3}{*}{ Összesen } \\
\hline & \multicolumn{2}{|c|}{ Román } & \multicolumn{2}{|c|}{ Német } & \multicolumn{2}{|c|}{ Magyar } & \multicolumn{2}{|c|}{ Zsidó } & \multicolumn{2}{|c|}{ Egyéb } & \\
\hline & & $\%$ & & $\%$ & & $\%$ & & $\%$ & & $\%$ & \\
\hline $1921 / 1922$ & 3630 & 32,9 & & & & & 1230 & 11,2 & 6162 & & 11022 \\
\hline $1922 / 1923$ & 4140 & 35,5 & & & & & 1250 & 10,7 & 6257 & & 11647 \\
\hline $1923 / 1924$ & 4745 & 52,3 & 907 & 10,0 & 2397 & 26,4 & 871 & 9,6 & 88 & 1,0 & 9080 \\
\hline $1924 / 1925$ & 4072 & 50,8 & 957 & 11,9 & 2109 & 26,3 & 732 & 9,1 & 153 & 1,9 & 8023 \\
\hline $1925 / 1926$ & 3860 & 50,5 & 897 & 11,7 & 2123 & 27,8 & 621 & 8,1 & 140 & 1,8 & 7641 \\
\hline $1926 / 1927$ & 2474 & 49,0 & 643 & 12,7 & 1296 & 25,7 & 428 & 8,5 & 211 & 4,2 & 5052 \\
\hline $1927 / 1928$ & 1709 & 49,9 & 609 & 17,8 & 877 & 25,6 & 147 & 4,3 & 81 & 2,4 & 3423 \\
\hline
\end{tabular}

Az etnikai vonatkozású változásokhoz hasonló folyamatok figyelhetőek meg felekezeti szinten is. A görögkeletiek aránya 1927-re 33,2-ről 43,3 százalékra nőtt, ezzel szemben az izraelitáké 11,2-ről 4,3-ra csökkent. Az állami fenntartású polgári iskolákban a görögkeletieket a római katolikusok követték számbelileg, majd a görög katolikusok és a reformátusok. Az unitáriusok és az evangélikusok aránya elenyésző volt.

38. Az állami fenntartású polgári iskolák diákjainak felekezeti megoszlása:

\begin{tabular}{|c|c|c|c|c|c|c|c|c|c|}
\hline & 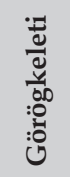 & 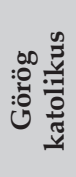 & 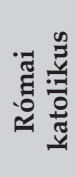 & 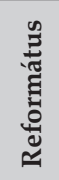 & & 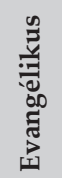 & 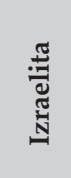 & 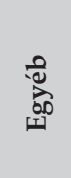 & $\begin{array}{l}\tilde{D} \\
\text { Dू } \\
\text { N } \\
: 00\end{array}$ \\
\hline $1921 / 1922$ & 3657 & & & & & & 1230 & 6135 & 11022 \\
\hline $1922 / 1923$ & 4156 & & & & & & 1250 & 6241 & 11647 \\
\hline $1923 / 1924$ & 3567 & 1305 & 2226 & 901 & 34 & 145 & 871 & 31 & 9080 \\
\hline $1924 / 1925$ & 3317 & 924 & 2027 & 792 & 34 & 163 & 732 & 34 & 8023 \\
\hline $1925 / 1926$ & 3084 & 808 & 2126 & 771 & 55 & 142 & 621 & 34 & 7641 \\
\hline $1926 / 1927$ & 2138 & 472 & 1486 & 416 & 36 & 73 & 428 & 3 & 5052 \\
\hline $1927 / 1928$ & 1481 & 275 & 1188 & 275 & 6 & 46 & 147 & 5 & 3423 \\
\hline
\end{tabular}


39. Az állami fenntartású polgári iskolák diákjainak felekezeti megoszlása, százalékban kifejezve:

\begin{tabular}{|c|c|c|c|c|c|c|c|c|}
\hline & \multicolumn{8}{|c|}{ Beiratkozottak vallása } \\
\hline & 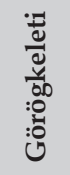 & 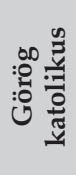 & 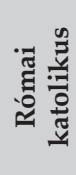 & 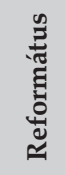 & 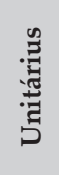 & 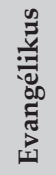 & & 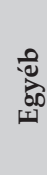 \\
\hline $1921 / 1922$ & 33,2 & & & & & & 11,2 & \\
\hline $1922 / 1923$ & 35,7 & & & & & & 10,7 & \\
\hline $1923 / 1924$ & 39,3 & 14,4 & 24,5 & 9,9 & 0,4 & 1,6 & 9,6 & 0,3 \\
\hline $1924 / 1925$ & 41,3 & 11,5 & 25,3 & 9,9 & 0,4 & 2,0 & 9,1 & 0,4 \\
\hline $1925 / 1926$ & 40,4 & 10,6 & 27,8 & 10,1 & 0,7 & 1,9 & 8,1 & 0,4 \\
\hline $1926 / 1927$ & 42,3 & 9,3 & 29,4 & 8,2 & 0,7 & 1,4 & 8,5 & 0,1 \\
\hline $1927 / 1928$ & 43,3 & 8,0 & 34,7 & 8,0 & 0,2 & 1,3 & 4,3 & 0,1 \\
\hline
\end{tabular}

Az egyházi fenntartású polgári iskolákra vonatkozóan az 1926/1927-es és az azt követő tanévekből rendelkezünk adatokkal. Mind a két évben összesen 45 intézmény működött, ebből 9 volt fiú-, 34 leány- és 2 vegyes polgári iskola. Az intézmények közül a legtöbbet a római katolikus egyház működtette, de az evangélikusok, reformátusok és izraeliták is rendelkeztek néhánnyal. Amint korábban is láthattuk, jellemző módon főként a kisebbségi hívekkel rendelkező egyházak tartottak fenn oktatási intézményeket. A polgári iskolák esetében is a magyarokat, németeket és a fóként magyar identitású/kultúrájú zsidókat tömörítő felekezetek voltak a müködtetők. Ennek megfelelően például az 1926/1927-es tanévben a diákok 99,6 százaléka is a kisebbségek köréből került ki. A román tanulók ebben az évben $0,4 \%$-ot, a zsidók 7,8\%-ot, a németek 36,4\%-ot, a magyarok pedig $54,8 \%$-ot alkottak.

40. Az egyházak által fenntartott polgári iskolák Erdélyben:

\begin{tabular}{|l|l|c|c|c|c|c|}
\hline \multicolumn{2}{|c|}{} & $\begin{array}{c}\text { Római } \\
\text { katolikus }\end{array}$ & Evangélikus & Református & Izraelita & Összesen \\
\hline \multirow{4}{*}{$1926 / 1927$} & Fiú & 6 & 2 & - & 1 & 9 \\
\cline { 2 - 7 } & Lány & 24 & 5 & 4 & 1 & 34 \\
\cline { 2 - 7 } & Vegyes & 2 & - & - & - & 2 \\
\cline { 2 - 7 } & Összesen & 32 & 7 & 4 & 2 & 45 \\
\hline \multirow{4}{*}{$1927 / 1928$} & Fiú & 6 & 2 & - & 1 & 9 \\
\cline { 2 - 7 } & Lány & 24 & 5 & 4 & 1 & 34 \\
\cline { 2 - 7 } & Vegyes & 2 & - & - & - & 2 \\
\cline { 2 - 7 } & Összesen & 32 & 7 & 4 & 2 & 45 \\
\hline
\end{tabular}


41. Az egyházak által fenntartott polgári iskolák diákjai:

\begin{tabular}{|l|l|c|c|c|}
\hline & \multicolumn{2}{|l|}{ Intézmény típusa } & Beiratkozott diákok & Felsőbb osztályba léptek \\
\hline \multirow{4}{*}{ 1926/1927 } & Fiú & 9 & 1319 & 1058 \\
\cline { 2 - 5 } & Lány & 34 & 5035 & 4443 \\
\cline { 2 - 5 } & Vegyes & 2 & 160 & 134 \\
\cline { 2 - 5 } & Összesen & 45 & 6514 & 5635 \\
\hline \multirow{4}{*}{ 1927/1928 } & Fiú & 9 & 1048 & 823 \\
\cline { 2 - 5 } & Lány & 34 & 4316 & 3767 \\
\cline { 2 - 5 } & Vegyes & 2 & 152 & 129 \\
\cline { 2 - 5 } & Összesen & 45 & 5516 & 4719 \\
\hline
\end{tabular}

\subsubsection{Gimnáziumok és alsó fokú leányiskolák}

A polgári iskolákkal párhuzamosan és azok szerepét fokozatosan átvéve az elemi oktatás következő lépcsőfokát a gimnáziumok képezték. A gimnáziumokba az elemi iskola első négy osztályának elvégzése után lehetett beiratkozni, és a képzés előbb négy-, majd az 1928-as középiskolai törvényt követően hároméves volt. A polgári iskolák számának csökkenésével párhuzamosan növekedett a gimnáziumok, illetve ezek diákjainak és tanárainak a száma. 1923-ban még csak 18 állami gimnázium működött Erdély területén, a következő évben viszont már 23, 1936-ban pedig már 48. Lánygimnáziumok az 1920-as években nem müködtek, szerepüket az I. fokú leány-középiskolák látták el, amelyeknek száma ugyancsak fokozatos emelkedést mutatott az évek során.

A vegyes gimnáziumok 1927-től jelentek meg, ahová egyaránt jártak fiú és lány diákok, majd 1929-től az I. fokú leány-középiskolák leánygimnáziumokká alakultak át (lásd bővebben a 11. sz. mellékletet). Ettől kezdve maguk a hivatalos statisztikák is együtt kezelték a fiú-, vegyes és leánygimnáziumok adatait. Az alábbi táblázatban tehát 1930/1931-től már nemcsak a fiúintézmények, hanem mindhárom gimnáziumtípus adatai szerepelnek.

42. Az állami gimnáziumok diákjai és tanárai:

\begin{tabular}{|l|c|c|c|c|}
\hline & Iskolák száma & Beiratkozottak & $\begin{array}{c}\text { Felsőbb osztályba } \\
\text { léptek }\end{array}$ & $\begin{array}{c}\text { Tanárok (mesterek } \\
\text { nélkül) }\end{array}$ \\
\hline $\mathbf{1 9 2 3 / 1 9 2 4}$ & 18 & 2054 & 1684 & 100 \\
\hline $\mathbf{1 9 2 4 / 1 9 2 5}$ & 23 & 2760 & 2150 & 126 \\
\hline $\mathbf{1 9 2 5 / 1 9 2 6}$ & 25 & 3190 & 2404 & 152 \\
\hline $\mathbf{1 9 2 6 / 1 9 2 7}$ & 26 & 3185 & 2483 & 166 \\
\hline $\mathbf{1 9 2 7 / 1 9 2 8}$ & 29 & 3428 & 2631 & 190 \\
\hline $\mathbf{1 9 2 8} / \mathbf{1 9 2 9}$ & 37 & 3977 & 2964 & 236 \\
\hline $\mathbf{1 9 3 0 / 1 9 3 1}$ & 57 & 5379 & 4131 & 475 \\
\hline
\end{tabular}




\begin{tabular}{|l|l|l|l|l|}
\hline $\mathbf{1 9 3 1 / 1 9 3 2}$ & 52 & 6170 & 5161 & 511 \\
\hline $\mathbf{1 9 3 2 / 1 9 3 3}$ & 51 & 7004 & 5898 & 497 \\
\hline $\mathbf{1 9 3 5 / 1 9 3 6}$ & 49 & 7520 & 6352 & 372 \\
\hline $\mathbf{1 9 3 6 / 1 9 3 7}$ & 48 & 7614 & 6540 & 486 \\
\hline
\end{tabular}

43. Az I. fokú állami leány-középiskolák diákjai és tanárai:

\begin{tabular}{|c|c|c|c|c|}
\hline & $\begin{array}{c}\text { Intézmények } \\
\text { száma }\end{array}$ & Beiratkozottak & $\begin{array}{c}\text { Felsőbb } \\
\text { osztályba léptek }\end{array}$ & $\begin{array}{c}\text { Tanárok (mesterek } \\
\text { nélkül) }\end{array}$ \\
\hline $\mathbf{1 9 2 3 / 1 9 2 4}$ & 13 & 1734 & 1446 & 91 \\
\hline $\mathbf{1 9 2 4 / 1 9 2 5}$ & 12 & 1815 & 1400 & 80 \\
\hline $\mathbf{1 9 2 5 / 1 9 2 6}$ & 13 & 1696 & 1288 & 79 \\
\hline $\mathbf{1 9 2 6 / 1 9 2 7}$ & 20 & 2390 & 1878 & 121 \\
\hline $\mathbf{1 9 2 7 / 1 9 2 8}$ & 23 & 2823 & 2207 & 149 \\
\hline $\mathbf{1 9 2 8 / 1 9 2 9}$ & 28 & 2622 & 1959 & 186 \\
\hline
\end{tabular}

Az állami gimnáziumok és alsó fokú leányiskolák tanulóinak többsége a román nemzetiségűek közül került ki, viszont a polgári iskolák számának csökkenésével egyidőben megfigyelhető a gimnáziumok nemzetiségi tanulóinak aránybeli növekedése is. Ennek tulajdonítható, hogy mind a magyarok, mind a zsidók aránya jelentősen megnőtt az 1930-as évek közepére az 1920-as évek elejéhez képest. Ez főként a leányiskolák esetében érhető tetten, hiszen az 1928-ban megszűnt 72 polgári iskolának 2/3-a leányintézmény volt.

44. Az állami gimnáziumok diákjainak nemzetiségi megoszlása:

\begin{tabular}{|c|c|c|c|c|c|c|c|c|c|c|c|}
\hline & \multicolumn{2}{|c|}{ Román } & \multicolumn{2}{c|}{ Német } & \multicolumn{2}{c|}{ Magyar } & \multicolumn{2}{c|}{ Zsidó } & \multicolumn{2}{|c|}{ Egyéb } & \multirow{2}{*}{ Összesen } \\
\cline { 2 - 10 } & & $\%$ & & $\%$ & & $\%$ & & $\%$ & & $\%$ & \\
\hline $\mathbf{1 9 2 3 / 1 9 2 4}$ & 1439 & 70,1 & 253 & 12,3 & 249 & 12,1 & 82 & 4,0 & 31 & 1,5 & 2054 \\
\hline $\mathbf{1 9 2 4 / 1 9 2 5}$ & 1975 & 71,6 & 191 & 6,9 & 444 & 16,1 & 132 & 4,8 & 18 & 0,7 & 2760 \\
\hline $\mathbf{1 9 2 5 / 1 9 2 6}$ & 2396 & 75,1 & 163 & 5,1 & 493 & 15,5 & 131 & 4,1 & 7 & 0,2 & 3190 \\
\hline $\mathbf{1 9 2 6 / 1 9 2 7}$ & 2447 & 76,8 & 165 & 5,2 & 393 & 12,3 & 175 & 5,5 & 5 & 0,2 & 3185 \\
\hline $\mathbf{1 9 2 7 / 1 9 2 8}$ & 2477 & 72,3 & 148 & 4,3 & 526 & 15,3 & 259 & 7,6 & 18 & 0,5 & 3428 \\
\hline $\mathbf{1 9 2 8 / 1 9 2 9}$ & 2450 & 61,6 & 454 & 11,4 & 757 & 19,0 & 213 & 5,4 & 103 & 2,6 & 3977 \\
\hline $\mathbf{1 9 3 5 / 1 9 3 6}$ & 4385 & 58,3 & 854 & 11,4 & 1474 & 19,6 & 670 & 8,9 & 137 & 1,8 & 7520 \\
\hline $\mathbf{1 9 3 6 / 1 9 3 7}$ & 4780 & 62,8 & 744 & 9,8 & 1326 & 17,4 & 622 & 8,2 & 142 & 1,9 & 7614 \\
\hline
\end{tabular}


45. Az I. fokú leány-középiskolák diákjainak nemzetiségi megoszlása:13

\begin{tabular}{|c|c|c|c|c|c|c|c|c|c|c|c|}
\hline & \multicolumn{10}{|c|}{ Beiratkozottak nemzetisége } & \multirow{3}{*}{ Összesen } \\
\hline & \multicolumn{2}{|c|}{ Román } & \multicolumn{2}{|c|}{ Német } & \multicolumn{2}{|c|}{ Magyar } & \multicolumn{2}{|c|}{ Zsidó } & \multicolumn{2}{|c|}{ Egyéb } & \\
\hline & & $\%$ & & $\%$ & & $\%$ & & $\%$ & & $\%$ & \\
\hline $1923 / 1924$ & 1091 & 62,9 & 45 & 2,6 & 400 & 23,1 & 190 & 11,0 & 8 & 0,5 & 1734 \\
\hline $1924 / 1925$ & 1135 & 62,5 & 32 & 1,8 & 422 & 23,3 & 220 & 12,1 & 6 & 0,3 & 1815 \\
\hline $1925 / 1926$ & 1148 & 67,7 & 35 & 2,1 & 324 & 19,1 & 185 & 10,9 & 4 & 0,2 & 1696 \\
\hline 1926/1927 & 1596 & 66,8 & 102 & 4,3 & 466 & 19,5 & 207 & 8,7 & 19 & 0,8 & 2390 \\
\hline $1927 / 1928$ & 1688 & 59,8 & 85 & 3,0 & 609 & 21,6 & 418 & 14,8 & 23 & 0,8 & 2823 \\
\hline $1928 / 1929$ & 1528 & 58,3 & 160 & 6,1 & 641 & 24,4 & 262 & 10,0 & 31 & 1,2 & 2622 \\
\hline
\end{tabular}

Az etnikai arányok változásához hasonló folyamatok figyelhetőek meg felekezeti vonatkozásban is. A görögkeletiek és görög katolikusok aránya csökkenő tendenciát mutatott, a római katolikus és protestáns felekezetüeké, valamint az izraelitáké pedig növekvőben volt 1936-ig.

46. Az állami gimnáziumok diákjainak felekezeti megoszlása:

\begin{tabular}{|c|c|c|c|c|c|c|c|c|c|}
\hline & \multicolumn{8}{|c|}{ Beiratkozottak vallása } & \multirow[b]{2}{*}{ Összesen } \\
\hline & 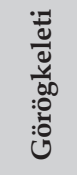 & 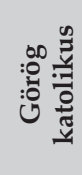 & 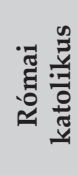 & 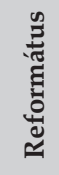 & & 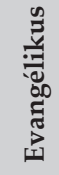 & 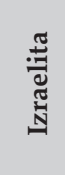 & 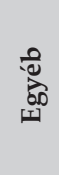 & \\
\hline $1923 / 1924$ & 1024 & 445 & 351 & 121 & 19 & 12 & 82 & - & 2054 \\
\hline $1924 / 1925$ & 1202 & 776 & 398 & 210 & 19 & 21 & 132 & 2 & 2760 \\
\hline $1925 / 1926$ & 1396 & 999 & 383 & 228 & 20 & 28 & 131 & 5 & 3190 \\
\hline $1926 / 1927$ & 1490 & 785 & 413 & 237 & 24 & 52 & 175 & 9 & 3185 \\
\hline $1927 / 1928$ & 1719 & 751 & 432 & 219 & 16 & 27 & 259 & 5 & 3428 \\
\hline $1928 / 1929$ & 1931 & 589 & 946 & 229 & 7 & 52 & 213 & 10 & 3977 \\
\hline $1930 / 1931$ & 1957 & 857 & 1401 & 448 & 19 & 116 & 553 & 28 & 5379 \\
\hline 1931/1932 & 2245 & 1036 & 1433 & 499 & 126 & 114 & 690 & 27 & 6170 \\
\hline $1932 / 1933$ & 2498 & 1233 & 1590 & 594 & 81 & 138 & 842 & 28 & 7004 \\
\hline $1935 / 1936$ & 3105 & 1272 & 1650 & 599 & 52 & 149 & 670 & 23 & 7520 \\
\hline $1936 / 1937$ & 3417 & 1348 & 1479 & 548 & 40 & 133 & 622 & 27 & 7614 \\
\hline
\end{tabular}

\footnotetext{
${ }^{13}$ Az 1927/1928-as tanévben közel megduplázódik a zsidó diáklányok száma. Ez annak tulajdonítható, hogy 1927 nyarán megszűnt a kolozsvári zsidó gimnázium, ahonnan jelentős számú zsidó diáklány áramlott át az I. fokú leány-középiskolákba.
} 
47. Az állami gimnáziumok növendékeinek felekezeti megoszlása, százalékban kifejezve:

\begin{tabular}{|c|c|c|c|c|c|c|c|c|}
\hline & \multicolumn{8}{|c|}{ Beiratkozottak vallása } \\
\hline & 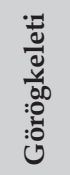 & 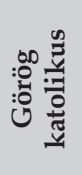 & 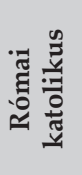 & 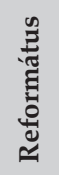 & & 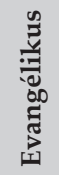 & 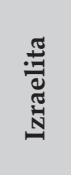 & 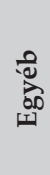 \\
\hline $1923 / 1924$ & 49,9 & 21,7 & 17,1 & 5,9 & 0,9 & 0,6 & 4,0 & - \\
\hline $1924 / 1925$ & 43,6 & 28,1 & 14,4 & 7,6 & 0,7 & 0,8 & 4,8 & 0,1 \\
\hline $1925 / 1926$ & 43,8 & 31,3 & 12,0 & 7,1 & 0,6 & 0,9 & 4,1 & 0,2 \\
\hline $1926 / 1927$ & 46,8 & 24,6 & 13,0 & 7,4 & 0,8 & 1,6 & 5,5 & 0,3 \\
\hline $1927 / 1928$ & 50,1 & 21,9 & 12,6 & 6,4 & 0,5 & 0,8 & 7,6 & 0,1 \\
\hline $1928 / 1929$ & 48,6 & 14,8 & 23,8 & 5,8 & 0,2 & 1,3 & 5,4 & 0,3 \\
\hline 1930/1931 & 36,4 & 15,9 & 26,0 & 8,3 & 0,4 & 2,2 & 10,3 & 0,5 \\
\hline 1931/1932 & 36,4 & 16,8 & 23,2 & 8,1 & 2,0 & 1,8 & 11,2 & 0,4 \\
\hline $1932 / 1933$ & 35,7 & 17,6 & 22,7 & 8,5 & 1,2 & 2,0 & 12,0 & 0,4 \\
\hline $1935 / 1936$ & 41,3 & 16,9 & 21,9 & 8,0 & 0,7 & 2,0 & 8,9 & 0,3 \\
\hline $1936 / 1937$ & 44,9 & 17,7 & 19,4 & 7,2 & 0,5 & 1,7 & 8,2 & 0,4 \\
\hline
\end{tabular}

48. Az I. fokú leány-középiskolák diákjainak felekezeti megoszlása:

\begin{tabular}{|c|c|c|c|c|c|c|c|c|c|}
\hline & \multicolumn{8}{|c|}{ Beiratkozottak vallása } & \multirow[b]{2}{*}{ Összesen } \\
\hline & 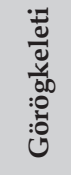 & 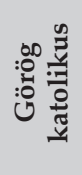 & 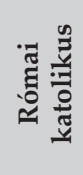 & 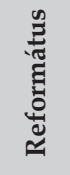 & & 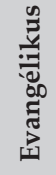 & 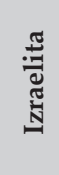 & 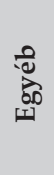 & \\
\hline 1923/1924 & 437 & 629 & 211 & 202 & 33 & 24 & 190 & 8 & 1734 \\
\hline $1924 / 1925$ & 434 & 690 & 223 & 195 & 30 & 19 & 220 & 4 & 1815 \\
\hline $1925 / 1926$ & 532 & 599 & 183 & 147 & 32 & 18 & 185 & - & 1696 \\
\hline $1926 / 1927$ & 931 & 627 & 358 & 196 & 21 & 50 & 207 & - & 2390 \\
\hline $1927 / 1928$ & 999 & 692 & 401 & 208 & 28 & 66 & 418 & 11 & 2823 \\
\hline 1928/1929 & 1031 & 486 & 544 & 258 & 5 & 28 & 262 & 8 & 2622 \\
\hline
\end{tabular}

49. Az I. fokú leány-középiskolák diákjainak felekezeti megoszlása, százalékban kifejezve:

\begin{tabular}{|c|c|c|c|c|c|c|c|}
\hline & \multicolumn{7}{|c|}{ Beiratkozottak vallása } \\
\hline & 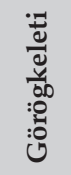 & 苟 & 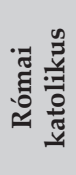 & 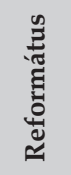 & 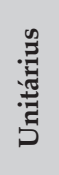 & 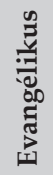 & 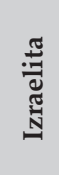 \\
\hline $1923 / 1924$ & 25,2 & 36,3 & 12,2 & 11,6 & 1,9 & 1,4 & 11,0 \\
\hline $1924 / 1925$ & 23,9 & 38,0 & 12,3 & 10,7 & 1,7 & 1,0 & 12,1 \\
\hline
\end{tabular}




\begin{tabular}{|c|c|c|c|c|c|c|c|}
\hline $\mathbf{1 9 2 5} / \mathbf{1 9 2 6}$ & 31,4 & 35,3 & 10,8 & 8,7 & 1,9 & 1,1 & 10,9 \\
\hline $\mathbf{1 9 2 6 / 1 9 2 7}$ & 39,0 & 26,2 & 15,0 & 8,2 & 0,9 & 2,1 & 8,7 \\
\hline $\mathbf{1 9 2 7 / 1 9 2 8}$ & 35,4 & 24,5 & 14,2 & 7,4 & 1,0 & 2,3 & 14,8 \\
\hline $\mathbf{1 9 2 8} / \mathbf{1 9 2 9}$ & 39,3 & 18,5 & 20,7 & 9,8 & 0,2 & 1,1 & 10,0 \\
\hline
\end{tabular}

Egyházi gimnáziumokról az 1926-1928 közötti időszakból rendelkezünk kimutatásokkal. Ez az az időszak, amikor az intézmények számának gyors növekedése megy végbe, amely főként a megszűnő polgári iskolák, illetve a középfokú oktatás helyzetét tisztázó 1928. májusi középfokú oktatási törvény elfogadása következményének tekinthetô. Az egyházi iskolák számának alakulásán is tetten érhető ez, a törvény elfogadását megelőzően ugyanis csak 11 fiúgimnázium és első fokú leányiskola működött, az 1928/1929-es tanévben viszont a számuk 45-re ugrott.

50. Az egyházi gimnáziumok megoszlása Erdélyben:

\begin{tabular}{|c|c|c|c|c|c|}
\hline & & $\begin{array}{c}\text { Római } \\
\text { katolikus }\end{array}$ & Református & Evangélikus & Izraelita \\
\hline \multirow[b]{2}{*}{$1926 / 1927$} & Fiúgimnázium & - & - & 3 & - \\
\hline & $\begin{array}{l}\text { I. fokú leány- } \\
\text { középiskola }\end{array}$ & - & 3 & 2 & 2 \\
\hline \multirow[b]{2}{*}{$1927 / 1928$} & Fiúgimnázium & - & - & 3 & \\
\hline & $\begin{array}{l}\text { I. fokú leány- } \\
\text { középiskola }\end{array}$ & - & 4 & 2 & 2 \\
\hline \multirow{3}{*}{$1928 / 1929$} & Fiúgimnázium & 2 & 1 & 3 & 1 \\
\hline & $\begin{array}{l}\text { I. fokú leány- } \\
\text { középiskola }\end{array}$ & 22 & 6 & 6 & 2 \\
\hline & Vegyes & 2 & - & - & - \\
\hline
\end{tabular}

Ugyanez a számbeli növekedés figyelhető meg a tanulók létszámán is. 1926/1927-ben az egyházak által fenntartott fiúgimnáziumokba és alsó fokú leány-középiskolákba összesen 1001 diák iratkozott be, két évvel később már 4300 felett volt a számuk. Az egyházi intézmények esetében alacsonyabb fokú lemorzsolódást figyelhetünk meg a tanulók körében. Összehasonlítva az állami iskolák fiú- és vegyes gimnáziumaiban felsőbb osztályba továbblépett diákok arányát az egyházi intézmények hasonló osztályaival, néhány százalékos eltéréseket kapunk. Az egyházi fiú- és vegyes gimnáziumokban 1926/1927-ben a tanulók 86,7\%-a, míg az államiakban hetvennyolc százaléka lépett felsőbb osztályba. A következő két évben a különbség csökkent: 1927/1928-ban 82,4\%, illetve 76,8\% volt ez az arány, az ezt követő tanévben pedig $76 \%$ és $74,5 \%$. 
51. Az egyházi gimnáziumok tanulói és tanárai:

\begin{tabular}{|c|c|c|c|c|c|}
\hline & & $\begin{array}{c}\text { Intézmények } \\
\text { száma }\end{array}$ & Beiratkozottak & $\begin{array}{c}\text { Felsőbb } \\
\text { osztályba } \\
\text { léptek }\end{array}$ & $\begin{array}{c}\text { Tanárok } \\
\text { (mesterek } \\
\text { nélkül) }\end{array}$ \\
\hline \multirow{4}{*}{ 1926/1927 } & Fiúgimnázium & 3 & 263 & 228 & 24 \\
\hline & $\begin{array}{l}\text { I. fokú leány- } \\
\text { középiskola }\end{array}$ & 7 & 738 & 639 & 75 \\
\hline & \begin{tabular}{|l|} 
Vegyes \\
\end{tabular} & - & - & - & - \\
\hline & \begin{tabular}{|l|} 
Összesen \\
\end{tabular} & 10 & 1001 & 867 & 99 \\
\hline \multirow{4}{*}{$1927 / 1928$} & Fiúgimnázium & 3 & 205 & 169 & 22 \\
\hline & \begin{tabular}{|l}
$\begin{array}{l}\text { I. fokú leány- } \\
\text { középiskola }\end{array}$ \\
\end{tabular} & 8 & 615 & 529 & 61 \\
\hline & \begin{tabular}{|l|} 
Vegyes \\
\end{tabular} & - & - & - & - \\
\hline & Összesen & 11 & 820 & 698 & 83 \\
\hline \multirow{4}{*}{ 1928/1929 } & Fiúgimnázium & 7 & 605 & 454 & 55 \\
\hline & $\begin{array}{l}\text { I. fokú leány- } \\
\text { középiskola }\end{array}$ & 36 & 3587 & 2924 & 292 \\
\hline & \begin{tabular}{|l|} 
Vegyes \\
\end{tabular} & 2 & 149 & 119 & 10 \\
\hline & \begin{tabular}{|l|} 
Összesen \\
\end{tabular} & 45 & 4341 & 3497 & 357 \\
\hline
\end{tabular}

Az egyházi gimnáziumokat és alsó fokú leányiskolákat elsősorban a kisebbségi felekezetek müködtették, és ennek megfelelően kisebbségi gyermekek is látogatták őket. A románok átlaga a két iskolatípusban alig egy-két százalékot tett ki, ezzel szemben a magyarok és németek aránya volt a legnagyobb. Ugyanígy a zsidók is felülreprezentáltak voltak.

52. Az egyházi gimnáziumok diákjainak nemzetiségi megoszlása:

\begin{tabular}{|c|c|c|c|c|c|c|c|c|c|c|c|c|}
\hline & \multicolumn{10}{|c|}{ Beiratkozott diákok nemzetisége } & \multirow{3}{*}{$\begin{array}{c}\text { Össze- } \\
\text { sen }\end{array}$} \\
\hline & & \multicolumn{2}{|c|}{ Román } & \multicolumn{2}{|c|}{ Német } & \multicolumn{2}{|c|}{ Magyar } & \multicolumn{2}{|c|}{ Zsidó } & \multicolumn{2}{|c|}{ Egyéb } & \\
\hline & & & $\%$ & & $\%$ & & $\%$ & & $\%$ & & \begin{tabular}{|l|}
$\%$ \\
\end{tabular} & \\
\hline \multirow{3}{*}{$1926 / 1927$} & \begin{tabular}{|l}
$\begin{array}{l}\text { Fiúgimná- } \\
\text { zium }\end{array}$ \\
\end{tabular} & 15 & 5,7 & 153 & 58,2 & 66 & 25,1 & 28 & 10,6 & 1 & 0,4 & 263 \\
\hline & $\begin{array}{l}\text { I. fokú leány- } \\
\text { középiskola }\end{array}$ & 9 & 1,2 & 138 & 18,7 & 428 & 58,0 & 162 & 22,0 & 1 & 0,1 & 738 \\
\hline & Összesen & 24 & 2,4 & 291 & 29,1 & 494 & 49,4 & 190 & 19,0 & 2 & 0,2 & 1001 \\
\hline \multirow{3}{*}{$1927 / 1928$} & \begin{tabular}{|l|}
$\begin{array}{l}\text { Fiúgimná- } \\
\text { zium }\end{array}$ \\
\end{tabular} & 1 & 0,5 & 131 & 63,9 & 56 & 27,3 & 14 & 6,8 & 3 & 1,5 & 205 \\
\hline & $\begin{array}{l}\text { I. fokú leány- } \\
\text { középiskola }\end{array}$ & 11 & 1,8 & 121 & 19,7 & 372 & 60,5 & 109 & 17,7 & 2 & 0,3 & 615 \\
\hline & Összesen & 12 & 1,5 & 252 & 30,7 & 428 & 52,2 & 123 & 15,0 & 5 & 0,6 & 820 \\
\hline \multirow{4}{*}{$1928 / 1929$} & \begin{tabular}{|l}
$\begin{array}{l}\text { Fiúgimná- } \\
\text { zium }\end{array}$ \\
\end{tabular} & - & - & 226 & 37,4 & 240 & 39,7 & 137 & 22,6 & 2 & 0,3 & 605 \\
\hline & \begin{tabular}{|l|} 
I. fokú leány- \\
középiskola
\end{tabular} & 7 & 0,2 & 1271 & 35,4 & 1909 & 53,2 & 253 & 7,1 & 147 & 4,1 & 3587 \\
\hline & \begin{tabular}{|l|} 
Vegyes \\
\end{tabular} & - & - & - & - & 149 & 100,0 & - & - & - & - & 149 \\
\hline & Összesen & 7 & 0,2 & 1497 & 34,5 & 2298 & 52,9 & 390 & 9,0 & 149 & 3,4 & 4341 \\
\hline
\end{tabular}


A vallási megoszlás az etnikai arányokat tükrözte. Így ezekben az intézményekben alig találkozunk görögkeleti és görög katolikus növendékekkel. A tanulók túlnyomó többségét a római katolikus, protestáns és izraelita diákok tették ki.

53. Az egyházi gimnáziumok diákjainak felekezeti megoszlása:

\begin{tabular}{|c|c|c|c|c|c|c|c|c|c|c|}
\hline & \multicolumn{8}{|c|}{ Beiratkozottak vallása } & \multirow[b]{2}{*}{$\begin{array}{c}\text { Össze- } \\
\text { sen }\end{array}$} \\
\hline & & 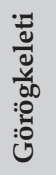 & 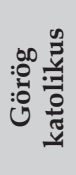 & 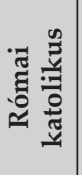 & 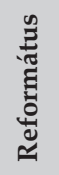 & & 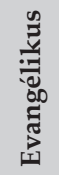 & 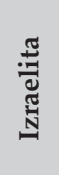 & 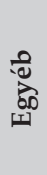 & \\
\hline \multirow{3}{*}{$1926 / 1927$} & $\begin{array}{l}\text { Fiúgimná- } \\
\text { zium }\end{array}$ & 10 & 5 & 32 & 12 & - & 175 & 28 & 1 & 263 \\
\hline & $\begin{array}{l}\text { I. fokú leány- } \\
\text { középiskola }\end{array}$ & 1 & 9 & 67 & 267 & 40 & 192 & 162 & - & 738 \\
\hline & Összesen & 11 & 14 & 99 & 279 & 40 & 367 & 190 & 1 & 1001 \\
\hline \multirow{3}{*}{$1927 / 1928$} & $\begin{array}{l}\text { Fiúgimná- } \\
\text { zium }\end{array}$ & - & 1 & 23 & 10 & - & 157 & 14 & - & 205 \\
\hline & $\begin{array}{l}\text { I. fokú leány- } \\
\text { középiskola }\end{array}$ & 5 & 6 & 57 & 240 & 32 & 166 & 109 & - & 615 \\
\hline & Összesen & 5 & 7 & 80 & 250 & 32 & 323 & 123 & - & 820 \\
\hline \multirow{4}{*}{$1928 / 1929$} & $\begin{array}{l}\text { Fiúgimná- } \\
\text { zium }\end{array}$ & - & - & 191 & 72 & - & 205 & 137 & - & 605 \\
\hline & $\begin{array}{l}\text { I. fokú leány- } \\
\text { középiskola }\end{array}$ & 5 & 4 & 1975 & 660 & 51 & 625 & 253 & 14 & 3587 \\
\hline & Vegyes & - & - & 146 & 3 & - & - & - & - & 149 \\
\hline & Összesen & 5 & 4 & 2312 & 735 & 51 & 830 & 390 & 14 & 4341 \\
\hline
\end{tabular}

54. Az egyházi gimnáziumok diákjainak felekezeti megoszlása, százalékban kifejezve:

\begin{tabular}{|c|c|c|c|c|c|c|c|c|}
\hline & \multicolumn{7}{|c|}{ Beiratkozottak vallása } \\
\hline & & 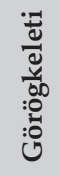 & 苞 & 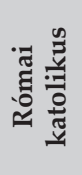 & 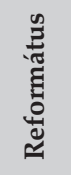 & & 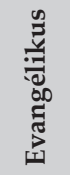 & 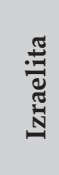 \\
\hline \multirow{3}{*}{ 1926/1927 } & Fiúgimnázium & 3,8 & 1,9 & 12,2 & 4,6 & - & 66,5 & 10,6 \\
\hline & $\begin{array}{l}\text { I. fokú leány- } \\
\text { középiskola }\end{array}$ & 0,1 & 1,2 & 9,1 & 36,2 & 5,4 & 26,0 & 22,0 \\
\hline & Összesen & 1,1 & 1,4 & 9,9 & 27,9 & 4,0 & 36,7 & 19,0 \\
\hline \multirow{3}{*}{$1927 / 1928$} & Fiúgimnázium & - & 0,5 & 11,2 & 4,9 & - & 76,6 & 6,8 \\
\hline & $\begin{array}{l}\text { I. fokú leány- } \\
\text { középiskola }\end{array}$ & 0,8 & 1,0 & 9,3 & 39,0 & 5,2 & 27,0 & 17,7 \\
\hline & Összesen & 0,6 & 0,9 & 9,8 & 30,5 & 3,9 & 39,4 & 15,0 \\
\hline
\end{tabular}




\begin{tabular}{|c|l|c|c|c|c|c|c|c|}
\hline \multirow{3}{*}{ 1928/1929 } & Fiúgimnázium & - & - & 31,6 & 11,9 & & 33,9 & 22,6 \\
\cline { 2 - 9 } & $\begin{array}{l}\text { I. fokú leány- } \\
\text { középiskola }\end{array}$ & 0,1 & 0,1 & 55,1 & 18,4 & 1,4 & 17,4 & 7,1 \\
\cline { 2 - 9 } & Vegyes & - & - & 98,0 & 2,0 & - & - & - \\
\cline { 2 - 9 } & Összesen & 0,1 & 0,1 & 53,3 & 16,9 & 1,2 & 19,1 & 9,0 \\
\hline
\end{tabular}

Láthattuk, amint az állami és egyházi gimnáziumok, leány-középiskolák száma, illetve diákjainak megoszlása fejlődött. Az állam ebben az esetben is jelentős befektetéseket eszközölt 1918-at követően, de elsősorban 1923-tól, amikor Angelescu oktatásügyi miniszter középiskola-építési kampánya elkezdődött. Az 1928/1929-es tanévben összesen 110 gimnázium és leány-középiskola működött Erdély területén, amelyből 65 (59,1\%) volt állami és 45 (40,9\%) egyházi tulajdonban. Az egyházi intézmények magas száma viszont csalóka, ugyanis egy évvel korábban csak 11 (17,5\%) volt belölük. A gyors növekedés tehát ebben az esetben nem az egyházak infrastrukturális befektetéseinek, hanem a túlnyomórészt egyházi fenntartású polgári iskolák gimnáziumokká történő átalakításának köszönhető.

55. Az erdélyi gimnáziumok és I. fokú leány-középiskolák megoszlása müködtetók szerint 1928/1929-ben:

\begin{tabular}{|l|c|c|c|}
\hline \multirow{2}{*}{} & \multicolumn{3}{|c|}{ Gimnáziumok és I. fokú leány-középiskolák } \\
\cline { 2 - 4 } & Állami & Egyházi & Összesen \\
\hline Intézmények & 59,1 & 40,9 & $100 \%$ \\
\hline Diákok & 60,3 & 39,7 & $100 \%$ \\
\hline Tanárok & 54,2 & 45,8 & $100 \%$ \\
\hline
\end{tabular}

\subsubsection{Líceumok és felső fokú leányiskolák}

Az érettségi bizonyítványt nyújtó középfokú intézmények legfontosabb pillére a líceum és az ennek megfelelő képzést nyújtó felső fokú leányiskola volt. Az 1919/1920-as tanévre nézve összetett kimutatással rendelkezünk a líceumokat illetően. Ekkor Erdélyben 36 állami, 3 községi és 45 egyházi líceum müködött, összesen 24081 beiratkozott tanulóval. Az egyházi intézmények közül a legtöbb a római katolikus, református és evangélikus egyházak felügyelete alatt állt. Amint az alábbi táblázatban is látható, a beiratkozott diákoknak alig egy töredéke érettségizett le. Amíg a felsőbb osztályba lépők aránya az állami líceumokban 87,6 százalékos volt, addig az érettségizőké csupán 3\%. A községi iskolákban a tanulók 92,7 százaléka tanult tovább, és 5,4 százalékuk abszolvált. Az egyházi iskolákban az érettségizők aránya valamivel magasabb, 7,1 százalékos volt. Összesítve a különböző fenntartók által működtetett intézményeket, átlagban a diá- 
kok 88,8 százaléka lépett felsőbb osztályba és 5,3 százalékuk érettségizett le az 1919/1920-as tanévben.

56. Líceumok és diákjaik Erdélyben az 1919/1920-as tanévben:

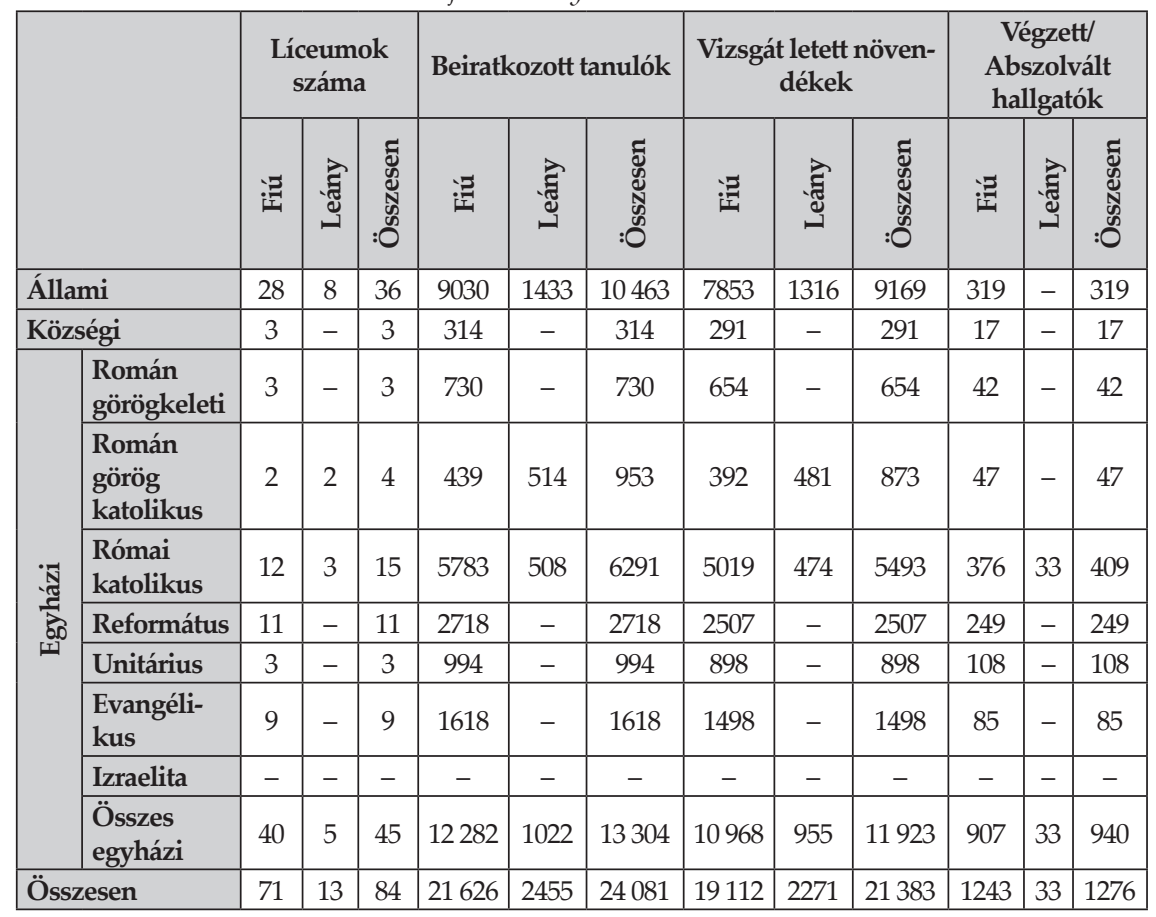

Az 1920-as években mind az állami fiúlíceumok, mind a felső fokú leányiskolák tekintetében növekedést tapasztalhatunk, és az 1930-as évek elejére többé-kevésbé kialakult a líceumi intézményrendszer Erdélyben.

A tanulók létszáma is folyamatosan nőtt 1924/1925-ig, majd ezt követően 1931/1932-ig csökkenés mutatható ki. 1932-t követően újabb létszámbeli gyarapodásnak lehetünk tanúi, és ennek köszönhetően az 1935/1936-os tanévben a diákok száma már meghaladta a húszezret. Az évről évre javuló tanár-diák arány a líceumi infrastruktúrát érintő állami fejlesztések volumenére is következtetni enged. 1921/1922-ben egy tanárra 25,6 diák, 1936/1937-re már csak 16,6 jutott. Összehasonlításképpen utaljunk az állami elemi iskolák helyzetére, ahol ez az arány inkább romlott az illető periódusban, mint javult (52-ről 54 diák/tanárra).

A két világháború közötti évekre vonatkozó statisztikákból sajnos nem derül ki az érettségizettek száma. Ismerjük viszont az 1920-as években az alsó és felső tagozatokban tanuló, felsőbb osztályokba lépő diákok adatait. 
Ekkor a felső tagozatokon átlagban 75-85 százalékos volt a felsőbb osztályokba lépők aránya (lásd bővebben a 15-16. sz. mellékleteket).

57. Érettségit nyújtó állami fiúlíceumok és II. fokú leány-középiskolák (leánylíceumok):

\begin{tabular}{|c|c|c|c|}
\hline & $\begin{array}{c}\text { Intézmények } \\
\text { száma }\end{array}$ & $\begin{array}{c}\text { Összes beiratkozott tanuló } \\
\text { alsó és felső tagozaton }\end{array}$ & $\begin{array}{c}\text { Tanárok } \\
\text { (mesterek nélkül) }\end{array}$ \\
\hline $\mathbf{1 9 2 1 / 1 9 2 2}$ & 38 & 13103 & 512 \\
\hline $\mathbf{1 9 2 2 / 1 9 2 3}$ & 45 & 15773 & 571 \\
\hline $\mathbf{1 9 2 3 / 1 9 2 4}$ & 42 & 18027 & 611 \\
\hline $\mathbf{1 9 2 4 / 1 9 2 5}$ & 45 & 19395 & 635 \\
\hline $\mathbf{1 9 2 5 / 1 9 2 6}$ & 47 & 19157 & 645 \\
\hline $\mathbf{1 9 2 6 / 1 9 2 7}$ & 51 & 18885 & 745 \\
\hline $\mathbf{1 9 2 7 / 1 9 2 8}$ & 52 & 18158 & 780 \\
\hline $\mathbf{1 9 2 8 / 1 9 2 9}$ & 55 & 17329 & 788 \\
\hline $\mathbf{1 9 3 0 / 1 9 3 1}$ & 51 & 15555 & 989 \\
\hline $\mathbf{1 9 3 1 / 1 9 3 2}$ & 52 & 15736 & 1034 \\
\hline $\mathbf{1 9 3 2 / 1 9 3 3}$ & 50 & 16136 & 1031 \\
\hline $\mathbf{1 9 3 5 / 1 9 3 6}$ & 55 & 20683 & 1090 \\
\hline $\mathbf{1 9 3 6 / 1 9 3 7}$ & 55 & 21333 & 1284 \\
\hline
\end{tabular}

Habár nem áll rendelkezésünkre összesített kimutatás az érettségizőkről, tudjuk, hogy az 1925-től bevezetett új érettségi rendszer nagyon hátrányosan érintette a kisebbségi diákokat és az első években alig 32 százalékuk tette le sikeresen a baccalaureatust (Balogh 1996: 109). A rossz érettségi eredmények mindvégig jellemzőek maradtak a két világháború közötti időszakra. Az 1934 júniusában érettségire jelentkező erdélyi református magyar diákoknak például a nyolcvanöt százalékát buktatták el (Bíró 2002: 384).

Az érettségit nyújtó fiú állami líceumok és felsőfokú leányiskolák tanulóinak etnikai megoszlásáról csak az 1920-as évekből és 1935-1936-ból rendelkezünk adatokkal. Mindkét iskolatípusnál a román tanulók száma dominált. Az 1921-1922 közötti tanéveket leszámítva, amikor a románok aránya a fiúintézményekben ötven százalék alatt volt, mind a lányok, mind a fiúk aránya általában meghaladta a hetven százalékot. A magyarok a két iskolatípusban összesen kilenc-tizenkét százalékot, a zsidók 7-12\%-ot, a németek pedig öt-hat százalékot tettek ki (lásd bővebben a 17. sz. mellékletet). A román diákok arányának megnövekedése (11,3\%-al) és a kisebbségi tanulók számának visszaesése az 1918 utáni hatalomváltás következményének tekinthető. Az állami középiskolák, amelyek az első világháború végéig magyar tanítási nyelvűek voltak, 1918/1919-től román tanítási nyelvűekké változtak. Ennek következtében a kisebbségi egyházak iskolaalapítással próbálták megoldani az anyanyelvi oktatást, így a nemzetiségi 
tanulók létszáma az állami intézményekben visszaesett, az egyháziakban pedig dominánssá vált. Ez alól csak a zsidó diákok képeztek kivételt. Megfigyelhető, hogy a két világháború között a zsidó diákok aránya fokozatosan csökkent az egyházi iskolákban, és ezzel párhuzamosan nőtt az állami intézményekben. Itt, mint ahogy a gimnáziumok és elemi iskolák esetében, ugyancsak a zsidók kisebbségi iskolákból történő hatósági kiszorítása állt a háttérben.

58. Az érettségit nyújtó állami fiúlíceumok és II. fokú leány-középiskolák (leánylíceumok) diákjainak etnikai megoszlása:

\begin{tabular}{|c|c|c|c|c|c|c|c|c|c|c|c|}
\hline & \multicolumn{11}{|c|}{ Beiratkozott tanulók nemzetisége alsó és felső tagozaton összesen } \\
\hline & \multicolumn{2}{|c|}{ Román } & \multicolumn{2}{|c|}{ Német } & \multicolumn{2}{|c|}{ Magyar } & \multicolumn{2}{|c|}{ Zsidó } & \multicolumn{2}{|c|}{ Egyéb } & \multirow{2}{*}{$\begin{array}{c}\text { Össze- } \\
\text { sen }\end{array}$} \\
\hline & & $\%$ & & $\%$ & & $\%$ & & $\%$ & & $\%$ & \\
\hline 1921/1922 & 7274 & 55,5 & & & & & 683 & 5,2 & 5146 & 39,3 & 13103 \\
\hline 1922/1923 & 8296 & 52,6 & & & & & 931 & 5,9 & 6546 & 41,5 & 15773 \\
\hline 1923/1924 & 13036 & 72,3 & 974 & 5,4 & 2135 & 11,8 & 1530 & 8,5 & 352 & 2,0 & 18027 \\
\hline $1924 / 1925$ & 13910 & 71,7 & 1125 & 5,8 & 2408 & 12,4 & 1605 & 8,3 & 347 & 1,8 & 19395 \\
\hline $1925 / 1926$ & 14093 & 73,6 & 1177 & 6,1 & 2132 & 11,1 & 1474 & 7,7 & 281 & 1,5 & 19157 \\
\hline $1926 / 1927$ & 14284 & 75,6 & 1029 & 5,4 & 1807 & 9,6 & 1448 & 7,7 & 317 & 1,7 & 18885 \\
\hline $1927 / 1928$ & 13527 & 74,5 & 936 & 5,2 & 1819 & 10,0 & 1572 & 8,7 & 304 & 1,7 & 18158 \\
\hline $1928 / 1929$ & 12946 & 74,7 & 862 & 5,0 & 1733 & 10,0 & 1564 & 9,0 & 224 & 1,3 & 17329 \\
\hline $1935 / 1936$ & 14484 & 70,0 & 1184 & 5,7 & 2159 & 10,4 & 2586 & 12,5 & 270 & 1,3 & 20683 \\
\hline $1936 / 1937$ & 15369 & 72,0 & 1102 & 5,2 & 2065 & 9,7 & 2502 & 11,7 & 295 & 1,4 & 21333 \\
\hline
\end{tabular}

A felekezeti megoszlás szintén az intézmények szintjén beállott változásokat tükrözi. A főként román etnikumúakat magukban foglaló görögkeleti és görög katolikus egyházakhoz tartozó diákok együttes aránya 1923-at követően meghaladta a hetven százalékot, míg a római katolikus, protestáns és izraelita növendékek összesen húsz-huszonöt százalékot tettek ki (lásd bővebben a 18-19. sz. mellékleteket).

Az állami középiskolai oktatás románosítása, illetve az a cél, hogy ezekben az intézményekben elsősorban a román társadalmi elit utánpótlását, illetve pozíciójának megerősítését biztosítsák, nemcsak az etnikai arányokban, hanem a felekezetek közötti megoszlásban is lemérhető. A két szélső év, tehát 1921/1922 és 1936/1937 között a diákok száma 62,8\%-kal nőtt, miközben az elsősorban kisebbségiekből álló római katolikus, református gyermekek száma kismértékben csökkent. A görögkeleti diákok száma 42,5\%-kal nőtt, a görög katolikusoké pedig 19,3\%-kal. Az izraelita tanulók száma az évek során megnégyszereződött. Ebben az esetben viszont érdemes megjegyezni, hogy megközelítőleg ugyanennyivel csökkent az egyházi líceumok zsidó diákjainak létszáma ebben a periódusban. 
59. Az érettségit nyújtó állami fiúlíceumok és II. fokú leány-középiskolák (leánylíceumok) diákjainak felekezeti megoszlása:

\begin{tabular}{|c|c|c|c|c|c|c|c|c|c|}
\hline & \multicolumn{9}{|c|}{ Beiratkozott tanulók felekezeti megoszlása alsó és felső tagozaton összesen } \\
\hline & 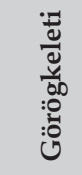 & 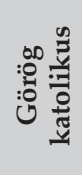 & 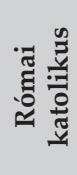 & 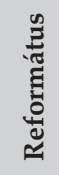 & 泀 & 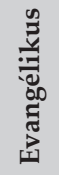 & 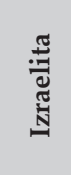 & $\sum_{000}^{00}$ & 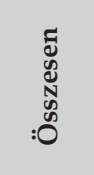 \\
\hline $1921 / 1922$ & 6818 & & & & & & 683 & 5114 & 13103 \\
\hline $1922 / 1923$ & 7849 & & & & & & 931 & 6525 & 15773 \\
\hline 1923/1924 & 8343 & 4810 & 2204 & 840 & 40 & 159 & 1530 & 101 & 18027 \\
\hline $1924 / 1925$ & 9031 & 5021 & 2404 & 870 & 87 & 295 & 1605 & 82 & 19395 \\
\hline $1925 / 1926$ & 9153 & 5028 & 2354 & 777 & 78 & 261 & 1474 & 32 & 19157 \\
\hline $1926 / 1927$ & 9277 & 5070 & 1987 & 759 & 51 & 197 & 1448 & 96 & 18885 \\
\hline $1927 / 1928$ & 8966 & 4727 & 1889 & 697 & 47 & 211 & 1572 & 49 & 18158 \\
\hline $1928 / 1929$ & 8536 & 4448 & 1745 & 718 & 53 & 222 & 1564 & 43 & 17329 \\
\hline $1930 / 1931$ & 7223 & 4219 & 1627 & 589 & 55 & 185 & 1633 & 24 & 15555 \\
\hline $1931 / 1932$ & 6999 & 4236 & 1798 & 628 & 54 & 196 & 1771 & 54 & 15736 \\
\hline $1932 / 1933$ & 7004 & 4215 & 1969 & 670 & 59 & 229 & 1943 & 47 & 16136 \\
\hline $1935 / 1936$ & 9147 & 5410 & 2242 & 788 & 112 & 354 & 2586 & 44 & 20683 \\
\hline $1936 / 1937$ & 9717 & 5736 & 2199 & 750 & 97 & 292 & 2502 & 40 & 21333 \\
\hline
\end{tabular}

60. Az érettségit nyújtó állami fiúlíceumok és II. fokú leány-középiskolák (leánylíceumok) diákjainak felekezeti megoszlása, százalékban kifejezve:

\begin{tabular}{|c|c|c|c|c|c|c|c|c|}
\hline & \multicolumn{8}{|c|}{ Beiratkozott tanulók felekezeti megoszlása alsó és felső tagozaton összesen } \\
\hline & 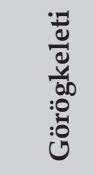 & 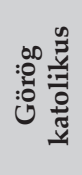 & 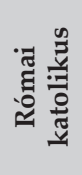 & 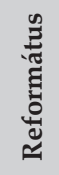 & & 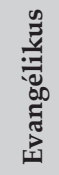 & 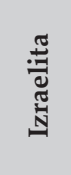 & $\underset{\substack{0.0 \\
.0}}{\stackrel{0}{0}}$ \\
\hline $1921 / 1922$ & 52,0 & & & & & & 5,2 & 39,0 \\
\hline $1922 / 1923$ & 49,8 & & & & & & 5,9 & 41,4 \\
\hline $1923 / 1924$ & 46,3 & 26,7 & 12,2 & 4,7 & 0,2 & 0,9 & 8,5 & 0,6 \\
\hline $1924 / 1925$ & 46,6 & 25,9 & 12,4 & 4,5 & 0,4 & 1,5 & 8,3 & 0,4 \\
\hline $1925 / 1926$ & 47,8 & 26,2 & 12,3 & 4,1 & 0,4 & 1,4 & 7,7 & 0,2 \\
\hline $1926 / 1927$ & 49,1 & 26,8 & 10,5 & 4,0 & 0,3 & 1,0 & 7,7 & 0,5 \\
\hline $1927 / 1928$ & 49,4 & 26,0 & 10,4 & 3,8 & 0,3 & 1,2 & 8,7 & 0,3 \\
\hline 1928/1929 & 49,3 & 25,7 & 10,1 & 4,1 & 0,3 & 1,3 & 9,0 & 0,2 \\
\hline 1930/1931 & 46,4 & 27,1 & 10,5 & 3,8 & 0,4 & 1,2 & 10,5 & 0,2 \\
\hline $1931 / 1932$ & 44,5 & 26,9 & 11,4 & 4,0 & 0,3 & 1,2 & 11,3 & 0,3 \\
\hline $1932 / 1933$ & 43,4 & 26,1 & 12,2 & 4,2 & 0,4 & 1,4 & 12,0 & 0,3 \\
\hline $1935 / 1936$ & 44,2 & 26,2 & 10,8 & 3,8 & 0,5 & 1,7 & 12,5 & 0,2 \\
\hline $1936 / 1937$ & 45,5 & 26,9 & 10,3 & 3,5 & 0,5 & 1,4 & 11,7 & 0,2 \\
\hline
\end{tabular}


A kisebbségi egyházak az 1920-as évek második felében 30 fiúlíceumot és felsőfokú leány-középiskolát működtettek. Közülük a legtöbbel a római katolikus egyház rendelkezett, őket a reformátusok és az evangélikusok követték.

61. Érettségit nyújtó egyházi fiúlíceumok és II. fokú leány-középiskolák:

\begin{tabular}{|c|c|c|c|c|c|c|c|}
\hline & & 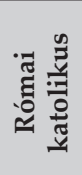 & 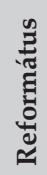 & 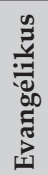 & & & 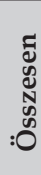 \\
\hline \multirow{3}{*}{$1926 / 1927$} & Fiúlíceum & 10 & 6 & 5 & 2 & 2 & 25 \\
\hline & $\begin{array}{l}\begin{array}{l}\text { II. fokú leány- } \\
\text { középiskola }\end{array} \\
\end{array}$ & 3 & 1 & 1 & - & - & 5 \\
\hline & Összesen & 13 & 7 & 6 & 2 & 2 & 30 \\
\hline \multirow{3}{*}{$1927 / 1928$} & Fiúlíceum & 10 & 6 & 5 & 2 & 2 & 25 \\
\hline & \begin{tabular}{|l}
$\begin{array}{l}\text { II. fokú leány- } \\
\text { középiskola }\end{array}$ \\
\end{tabular} & 3 & 1 & 1 & - & - & 5 \\
\hline & Összesen & 13 & 7 & 6 & 2 & 2 & 30 \\
\hline \multirow{3}{*}{$1928 / 1929$} & Fiúlíceum & 10 & 5 & 5 & 2 & 2 & 24 \\
\hline & $\begin{array}{l}\text { II. fokú leány- } \\
\text { középiskola }\end{array}$ & 3 & 1 & 1 & - & 1 & 6 \\
\hline & Összesen & 13 & 6 & 6 & 2 & 3 & 30 \\
\hline
\end{tabular}

A líceumi fokú egyházi intézményekben a vizsgált három évben 7000-8500 diák tanult. A felső tagozatokra beiratkozott növendékeknek nyolcvanöt-kilencven százaléka lépett felsőbb osztályba, amely felülmúlta az állami iskolák átlagát. Az egyházi oktatás visszaszorulását és ezzel a kisebbségi középiskolai rendszer leépülését jelzi viszont az, hogy miközben az állami intézmények jelentős, több mint $62 \%$-os diáklétszám-gyarapodást könyvelhettek el a két világháború között, az egyházi líceumokban 1919/1920 és 1928/1929 között felére csökkent a diákkontingens (lásd az 56. és az 57. táblázatokat). 
62. Érettségit nyújtó egyházi fiúlíceumok és II. fokú leány-középiskolák diákjai és tanárai:

\begin{tabular}{|c|c|c|c|c|c|c|c|c|}
\hline & \multirow[b]{2}{*}{ 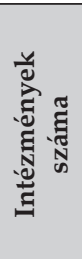 } & \multicolumn{2}{|c|}{ Alsó tagozat } & \multicolumn{2}{|c|}{ Felső tagozat } & \multirow[b]{2}{*}{ 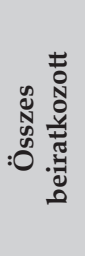 } & \multirow[b]{2}{*}{ 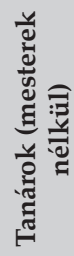 } \\
\hline & & & 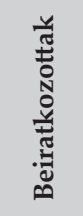 & 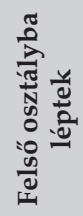 & 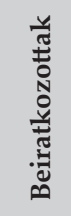 & 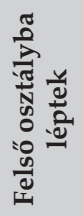 & & \\
\hline \multirow{3}{*}{ 1926/1927 } & Fiúlíceum & 25 & 4865 & 4094 & 2189 & 1994 & 7054 & 432 \\
\hline & $\begin{array}{l}\text { II. fokú leány- } \\
\text { középiskola }\end{array}$ & 5 & 1328 & 1128 & 222 & 197 & 1550 & 97 \\
\hline & \begin{tabular}{|l|} 
Összesen \\
\end{tabular} & 30 & 6193 & 5222 & 2411 & 2191 & 8604 & 529 \\
\hline \multirow{3}{*}{ 1927/1928 } & Fiúlíceum & 25 & 4697 & 3781 & 2086 & 1892 & 6783 & 439 \\
\hline & \begin{tabular}{|l|} 
II. fokú leány- \\
középiskola
\end{tabular} & 5 & 1215 & 1012 & 279 & 249 & 1494 & 100 \\
\hline & Összesen & 30 & 5912 & 4793 & 2365 & 2141 & 8277 & 539 \\
\hline \multirow{3}{*}{$1928 / 1929$} & Fiúlíceum & 24 & 3136 & 2542 & 2562 & 2175 & 5698 & 422 \\
\hline & $\begin{array}{l}\text { II. fokú leány- } \\
\text { középiskola }\end{array}$ & 6 & 844 & 663 & 535 & 444 & 1379 & 103 \\
\hline & Összesen & 30 & 3980 & 3205 & 3097 & 2619 & 7077 & 525 \\
\hline
\end{tabular}

A diákok többségét a magyarok alkották hatvankét-hatvannégy százalékos aránnyal, őket a németek (24-25\%) és a zsidók követték (8-10\%). A románok alig 1-1,4\%-ot tettek ki.

63. Az érettségit nyújtó egyházi fiúlíceumok és II. fokú leány-középiskolák diákjainak nemzetiségi megoszlása:

\begin{tabular}{|c|c|c|c|c|c|c|c|c|c|c|c|c|}
\hline & \multicolumn{11}{|c|}{ Beiratkozott növendékek alsó és felső tagozaton } \\
\hline & & \multicolumn{2}{|c|}{ Román } & \multicolumn{2}{|c|}{ Német } & \multicolumn{2}{|c|}{ Magyar } & \multicolumn{2}{|c|}{ Zsidó } & \multicolumn{2}{|c|}{ Egyéb } & \multirow{2}{*}{$\begin{array}{c}\text { Ösz- } \\
\text { szesen }\end{array}$} \\
\hline & & & $\%$ & & $\%$ & & $\%$ & & $\%$ & & $\%$ & \\
\hline \multirow{3}{*}{$1926 / 1927$} & Fiúlíceum & 79 & 1,1 & 1890 & 26,8 & 4373 & 62,0 & 663 & 9,4 & 49 & 0,7 & 7054 \\
\hline & \begin{tabular}{|l|} 
II. fokú \\
leány- \\
középiskola \\
\end{tabular} & 39 & 2,5 & 308 & 19,9 & 983 & 63,4 & 189 & 12,2 & 31 & 2,0 & 1550 \\
\hline & Összesen & 118 & 1,4 & 2198 & 25,5 & 5356 & 62,3 & 852 & 9,9 & 80 & 0,9 & 8604 \\
\hline \multirow{3}{*}{$1927 / 1928$} & Fiúlíceum & 41 & 0,6 & 1807 & 26,6 & 4324 & 63,7 & 571 & 8,4 & 40 & 0,6 & 6783 \\
\hline & \begin{tabular}{|l|} 
II. fokú \\
leány- \\
középiskola \\
\end{tabular} & 45 & 3,0 & 282 & 18,9 & 958 & 64,1 & 173 & 11,6 & 36 & 2,4 & 1494 \\
\hline & \begin{tabular}{|l|} 
Összesen \\
\end{tabular} & 86 & 1,0 & 2089 & 25,2 & 5282 & 63,8 & 744 & 9,0 & 76 & 0,9 & 8277 \\
\hline \multirow{3}{*}{$1928 / 1929$} & Fiúlíceum & 20 & 0,4 & 1477 & 25,9 & 3745 & 65,7 & 388 & 6,8 & 68 & 1,2 & 5698 \\
\hline & \begin{tabular}{|l|} 
II. fokú \\
leány- \\
középiskola \\
\end{tabular} & 67 & 4,9 & 268 & 19,4 & 833 & 60,4 & 169 & 12,3 & 42 & 3,0 & 1379 \\
\hline & 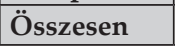 & 87 & 1,2 & 1745 & 24,7 & 4578 & 64,7 & 557 & 7,9 & 110 & 1,6 & 7077 \\
\hline
\end{tabular}


Felekezeti szempontból ugyancsak a kisebbségi egyházakhoz tartozó növendékek alkottak túlnyomó többséget. A római katolikusok aránya $36-38 \%$, a reformátusoké $24-26 \%$, az evangélikusoké $21-23 \%$, az unitáriusoké pedig 4-5\% körül mozgott. Az izraeliták nyolc-tíz százalékot tettek ki. Az elsősorban román etnikumú görögkeletiek és görög katolikusok együttes aránya $2 \%$ alatt maradt.

64. Az érettségit nyújtó egyházi fiúlíceumok és II. fokú leány-középiskolák diákjainak felekezeti megoszlása:

\begin{tabular}{|c|c|c|c|c|c|c|c|c|c|c|}
\hline & \multicolumn{9}{|c|}{ Beiratkozottak vallása } \\
\hline & & 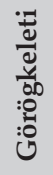 & 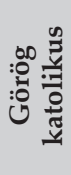 & 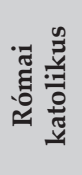 & 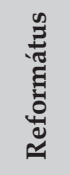 & 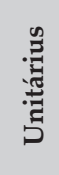 & 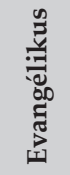 & 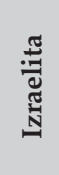 & 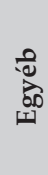 & $\begin{array}{l}\text { ฮี } \\
\text { ญ్ } \\
\text { : } \\
: 0\end{array}$ \\
\hline \multirow{3}{*}{$1926 / 1927$} & Fiúlíceum & 43 & 49 & 2523 & 1766 & 297 & 1708 & 663 & 5 & 7054 \\
\hline & $\begin{array}{l}\text { II. fokú } \\
\text { leány- } \\
\text { középiskola }\end{array}$ & 36 & 17 & 622 & 378 & 42 & 266 & 189 & - & 1550 \\
\hline & Összesen & 79 & 66 & 3145 & 2144 & 339 & 1974 & 852 & 5 & 8604 \\
\hline \multirow{3}{*}{$1927 / 1928$} & Fiúlíceum & 24 & 21 & 2451 & 1811 & 316 & 1587 & 571 & 2 & 6783 \\
\hline & \begin{tabular}{|l|} 
II. fokú \\
leány- \\
középiskola \\
\end{tabular} & 45 & 23 & 591 & 374 & 56 & 232 & 173 & - & 1494 \\
\hline & Összesen & 69 & 44 & 3042 & 2185 & 372 & 1819 & 744 & 2 & 8277 \\
\hline \multirow{3}{*}{ 1928/1929 } & Fiúlíceum & 20 & 9 & 2208 & 1532 & 286 & 1253 & 388 & 2 & 5698 \\
\hline & \begin{tabular}{|l|} 
II. fokú \\
leány- \\
középiskola \\
\end{tabular} & 52 & 38 & 507 & 337 & 54 & 222 & 169 & - & 1379 \\
\hline & Összesen & 72 & 47 & 2715 & 1869 & 340 & 1475 & 557 & 2 & 7077 \\
\hline
\end{tabular}

65. Az érettségit nyújtó egyházi fiúlíceumok és II. fokú leány-középiskolák diákjainak felekezeti megoszlása, százalékban kifejezve:

\begin{tabular}{|c|c|c|c|c|c|c|c|c|}
\hline & \multicolumn{7}{|c|}{ Beiratkozottak vallása } \\
\hline & & $\begin{array}{l}:= \\
0 \\
0 \\
00 \\
: 00 \\
: 00\end{array}$ & 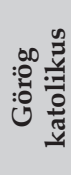 & 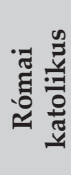 & 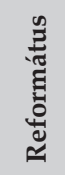 & & 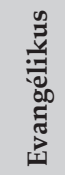 & 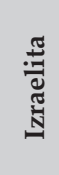 \\
\hline \multirow{3}{*}{$1926 / 1927$} & Fiúlíceum & 0,6 & 0,7 & 35,8 & 25,0 & 4,2 & 24,2 & 9,4 \\
\hline & $\begin{array}{l}\text { II. fokú } \\
\text { leány- } \\
\text { középiskola }\end{array}$ & 2,3 & 1,1 & 40,1 & 24,4 & 2,7 & 17,2 & 12,2 \\
\hline & Összesen & 0,9 & 0,8 & 36,6 & 24,9 & 3,9 & 22,9 & 9,9 \\
\hline
\end{tabular}




\begin{tabular}{|c|l|c|c|c|c|c|c|c|}
\hline \multirow{2}{*}{$\mathbf{1 9 2 7 / 1 9 2 8}$} & Fiúlíceum & 0,4 & 0,3 & 36,1 & 26,7 & 4,7 & 23,4 & 8,4 \\
\cline { 2 - 9 } & $\begin{array}{l}\text { II. fokú } \\
\text { leány- } \\
\text { középiskola }\end{array}$ & 3,0 & 1,5 & 39,6 & 25,0 & 3,7 & 15,5 & 11,6 \\
\cline { 2 - 9 } & Összesen & 0,8 & 0,5 & 36,8 & 26,4 & 4,5 & 22,0 & 9,0 \\
\hline \multirow{2}{*}{$\mathbf{1 9 2 8 / 1 9 2 9}$} & Fiúlíceum & 0,4 & 0,2 & 38,8 & 26,9 & 5,0 & 22,0 & 6,8 \\
\cline { 2 - 9 } & $\begin{array}{l}\text { II. fokú } \\
\text { leány- } \\
\text { középiskola }\end{array}$ & 3,8 & 2,8 & 36,8 & 24,4 & 3,9 & 16,1 & 12,3 \\
\cline { 2 - 5 } & 1,0 & 0,7 & 38,4 & 26,4 & 4,8 & 20,8 & 7,9 \\
\hline
\end{tabular}

\subsubsection{Kereskedelmi iskolák}

Az alábbiakban az elemi és középfokú képzést nyújtó kereskedelmi iskolák számbeli alakulását és diákjainak nemzetiségi, valamint felekezeti megoszlását mutatjuk be.

Az elemi szintű állami kereskedelmi oktatás elsősorban a fiúkat szólította meg. Habár Románia egyéb régióiban (Regát, Besszarábia) leányelemik is müködtek, ez Erdélyre nem volt jellemző.

Erdélyben az elemi szintű kereskedelmi oktatást állami intézmények látták el, magán-, illetve egyházi iskolák nem voltak. Az állami kereskedelmi iskolák száma az 1920-as években folyamatosan ingadozott. A legtöbb 1927-ben működött, ekkor 11 fiúintézményben tanulhattak a diákok. 1936-tól az elemi szintű kereskedelmi iskolák gimnáziumokká alakultak át. A tanulók létszámát illetően ugyancsak ingadozásokat figyelhetünk meg. Összehasonlítva a polgári iskolákba beiratkozott növendékek és a felsőbb osztályba lépők arányát a kereskedelmi iskolákkal, azt láthatjuk, hogy az utóbbiak esetében lényegesen többen hagyták félbe tanulmányaikat. Az 1923/1924-es tanévben például a polgári iskolákba beiratkozott gyermekek 81,7\%-a lépett felsőbb osztályba, míg a kereskedelmi iskoláknál 73,6\% volt ez az arány. Az is megfigyelhető, hogy az elemi szintű kereskedelmi iskolák gimnáziummá történő átalakulása a továbbtanulók tekintetében is javulásokat eredményezett. 1936/1937-ben a diákok 81,5\%-a lépett felsőbb osztályba. 
66. Az elemi szintú állami kereskedelmi iskolák diákjai és tanárai: ${ }^{14}$

\begin{tabular}{|c|c|c|c|c|c|}
\hline & & $\begin{array}{c}\text { Intézmények } \\
\text { száma }\end{array}$ & Beiratkozottak & $\begin{array}{c}\text { Felsőbb osztályba } \\
\text { léptek }\end{array}$ & $\begin{array}{c}\text { Tanárok } \\
\text { (mesterek } \\
\text { nélkül) }\end{array}$ \\
\hline \begin{tabular}{|l|}
$1923 / 1924$ \\
\end{tabular} & Fiú & 4 & 125 & 92 & 13 \\
\hline 1924/1925 & Fiú & 8 & 277 & 199 & 22 \\
\hline 1925/1926 & Fiú & 9 & 480 & 322 & 29 \\
\hline \begin{tabular}{|l|}
$1926 / 1927$ \\
\end{tabular} & Fiú & 9 & 570 & 415 & 44 \\
\hline 1927/1928 & Fiú & 11 & 542 & 404 & 68 \\
\hline 1928/1929 & Fiú & 9 & 439 & 327 & 52 \\
\hline \begin{tabular}{|l|}
$1930 / 1931$ \\
\end{tabular} & Fiú & 4 & 300 & 208 & 28 \\
\hline \begin{tabular}{|l|}
$1931 / 1932$ \\
\end{tabular} & Fiú & 2 & 162 & 128 & 15 \\
\hline 1932/1933 & Fiú & 2 & 190 & 146 & 11 \\
\hline \multirow{3}{*}{$1935 / 1936$} & Fiú & 5 & 347 & 259 & 38 \\
\hline & Lány & 1 & 62 & 56 & 12 \\
\hline & Összesen & 6 & 409 & 315 & 50 \\
\hline \begin{tabular}{|l|} 
1936/1937 \\
gimnázium
\end{tabular} & Fiú & 2 & 248 & 202 & 20 \\
\hline
\end{tabular}

A tanulók etnikai megoszlásáról az 1923-1928 és az 1935-1936 közötti időszakból rendelkezünk információkkal. Az állami intézményeket elsősorban a román nemzetiségü diákok látogatták, arányuk a két világháború közötti években hetven-nyolcvankilenc százalék között mozgott. A kisebbségekhez tartozó növendékek többsége magyar vagy zsidó volt. Az alábbi etnikai és felekezeti bontást közlő táblázatokból egyértelmü román túlsúly látszik, miközben a magyarok és németek alulreprezentáltak. A román túlsúly elsősorban a román tanítási nyelvnek tulajdonítható, valamint annak, hogy ezek az iskolák elsősorban olyan erdélyi településeken müködtek, ahol az államalkotó nemzet vagy többségben volt vagy jelentős arányt képviselt. A zsidó diákoknál a zsidó népesség körében megfigyelhető pályaorientáció adhat magyarázatot. Mint ahogy általában az elméleti középiskolákban, a kereskedelmi iskolákban is felülreprezentáltak voltak a zsidó diákok.

67. Az elemi szintü állami kereskedelmi iskolák diákjainak nemzetiségi megoszlása:

\begin{tabular}{|c|c|c|c|c|c|c|c|c|c|c|c|}
\hline & \multicolumn{2}{|c|}{ Román } & \multicolumn{2}{|c|}{ Német } & \multicolumn{2}{|c|}{ Magyar } & \multicolumn{2}{|c|}{ Zsidó } & \multirow{2}{*}{ 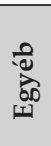 } & \multirow{2}{*}{ 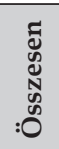 } \\
\hline & & & $\%$ & & $\%$ & & $\%$ & & $\%$ & & \\
\hline 1923/1924 & Fiú & 106 & 84,8 & 8 & 6,4 & 6 & 4,8 & 5 & 4,0 & - & 125 \\
\hline $1924 / 1925$ & Fiú & 244 & 88,1 & 6 & 2,2 & 19 & 6,9 & 8 & 2,9 & - & 277 \\
\hline
\end{tabular}

${ }^{14}$ A kimutatás nem tartalmazza az esti iskolák (cursuri serale suprapuse ale şcolilor elementare comerciale) adatait. 


\begin{tabular}{|l|l|c|c|c|c|c|c|c|c|c|c|}
\hline $\mathbf{1 9 2 5 / 1 9 2 6}$ & Fiú & 428 & 89,2 & 8 & 1,7 & 31 & 6,5 & 11 & 2,3 & 2 & 480 \\
\hline $\mathbf{1 9 2 6 / 1 9 2 7}$ & Fiú & 485 & 85,1 & 11 & 1,9 & 38 & 6,7 & 27 & 4,7 & 9 & 570 \\
\hline $\mathbf{1 9 2 7 / 1 9 2 8}$ & Fiú & 450 & 83,0 & 18 & 3,3 & 35 & 6,5 & 25 & 4,6 & 14 & 542 \\
\hline $\mathbf{1 9 2 8 / 1 9 2 9}$ & Fiú & 361 & 82,2 & 3 & 0,7 & 32 & 7,3 & 36 & 8,2 & 7 & 439 \\
\hline \multirow{2}{*}{$\mathbf{1 9 3 5 / 1 9 3 6}$} & Fiú & 241 & 69,5 & 18 & 5,2 & 40 & 11,5 & 44 & 12,7 & 4 & 347 \\
\cline { 2 - 11 } & Lány & 47 & 75,8 & - & - & 1 & 1,6 & 14 & 22,6 & - & 62 \\
\cline { 2 - 11 } & Összesen & 288 & 70,4 & 18 & 4,4 & 41 & 10,0 & 58 & 14,2 & 4 & 409 \\
\hline $\begin{array}{l}\mathbf{1 9 3 6 / 1 9 3 7} \\
\text { gimnázium }\end{array}$ & Fiú & 194 & 78,2 & 6 & 2,4 & 19 & 7,7 & 27 & 10,9 & 2 & 248 \\
\hline
\end{tabular}

Az elemi szintű állami kereskedelmi iskolákban a görögkeleti és görög katolikus vallású növendékek alkották a többséget. Arányuk csak az 1930-as évek első felében esett vissza, de ekkor is több mint ötven százalékot alkottak. Magasnak tekinthető az izraelita tanulók létszáma is, főként az 1930-as években. Ez a jelenség elsősorban a zsidóság egyenlőtlen foglalkozásszerkezetének és az ennek mentén kialakult pályaválasztási tendenciáknak köszönhető.

68. Az elemi szintú állami kereskedelmi iskolák diákjainak felekezeti megoszlása:

\begin{tabular}{|c|c|c|c|c|c|c|c|c|c|c|}
\hline & \multicolumn{9}{|c|}{ Beiratkozottak vallása } \\
\hline & & 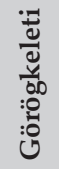 & 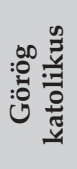 & 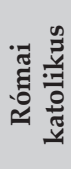 & 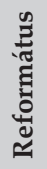 & 苞 & 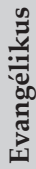 & 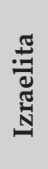 & 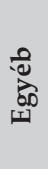 & 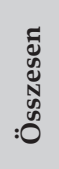 \\
\hline $1923 / 1924$ & Fiú & 71 & 29 & 17 & - & 3 & - & 5 & - & 125 \\
\hline $1924 / 1925$ & Fiú & 152 & 91 & 12 & 1 & 13 & - & 8 & - & 277 \\
\hline $1925 / 1926$ & Fiú & 252 & 171 & 26 & 1 & 14 & 3 & 11 & 2 & 480 \\
\hline 1926/1927 & Fiú & 300 & 184 & 37 & 1 & 20 & - & 27 & 1 & 570 \\
\hline $1927 / 1928$ & Fiú & 284 & 177 & 42 & - & 12 & 2 & 25 & - & 542 \\
\hline $1928 / 1929$ & Fiú & 246 & 119 & 19 & 17 & - & 2 & 36 & - & 439 \\
\hline 1930/1931 & Fiú & 111 & 106 & 24 & 1 & 16 & 1 & 41 & - & 300 \\
\hline $1931 / 1932$ & Fiú & 47 & 46 & 12 & 1 & 15 & 1 & 39 & 1 & 162 \\
\hline $1932 / 1933$ & Fiú & 69 & 44 & 12 & - & 17 & - & 47 & 1 & 190 \\
\hline \multirow{3}{*}{ 1935/1936 } & Fiú & 161 & 82 & 33 & 5 & 20 & 2 & 44 & - & 347 \\
\hline & Lány & 39 & 7 & - & - & 2 & - & 14 & - & 62 \\
\hline & Összesen & 200 & 89 & 33 & 5 & 22 & 2 & 58 & - & 409 \\
\hline $\begin{array}{l}\text { 1936/1937 } \\
\text { gimnázium }\end{array}$ & Fiú & 93 & 103 & 12 & 10 & - & 3 & 27 & - & 248 \\
\hline
\end{tabular}


69. Az elemi szintú állami kereskedelmi iskolák diákjainak felekezeti megoszlása, százalékban kifejezve:

\begin{tabular}{|c|c|c|c|c|c|c|c|c|}
\hline & \multicolumn{7}{|c|}{ Beiratkozottak vallása } \\
\hline & & 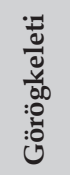 & 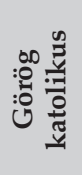 & 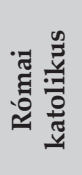 & 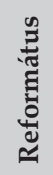 & & 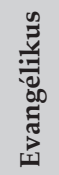 & 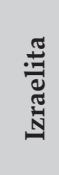 \\
\hline 1923/1924 & Fiú & 56,8 & 23,2 & 13,6 & - & 2,4 & - & 4,0 \\
\hline $1924 / 1925$ & Fiú & 54,9 & 32,9 & 4,3 & 0,4 & 4,7 & - & 2,9 \\
\hline $1925 / 1926$ & Fiú & 52,5 & 35,6 & 5,4 & 0,2 & 2,9 & 0,6 & 2,3 \\
\hline $1926 / 1927$ & Fiú & 52,6 & 32,3 & 6,5 & 0,2 & 3,5 & - & 4,7 \\
\hline $1927 / 1928$ & Fiú & 52,4 & 32,7 & 7,7 & - & 2,2 & 0,4 & 4,6 \\
\hline $1928 / 1929$ & Fiú & 56,0 & 27,1 & 4,3 & 3,9 & - & 0,5 & 8,2 \\
\hline $1930 / 1931$ & Fiú & 37,0 & 35,3 & 8,0 & 0,3 & 5,3 & 0,3 & 13,7 \\
\hline 1931/1932 & Fiú & 29,0 & 28,4 & 7,4 & 0,6 & 9,3 & 0,6 & 24,1 \\
\hline $1932 / 1933$ & Fiú & 36,3 & 23,2 & 6,3 & - & 8,9 & - & 24,7 \\
\hline \multirow{3}{*}{$1935 / 1936$} & Fiú & 46,4 & 23,6 & 9,5 & 1,4 & 5,8 & 0,6 & 12,7 \\
\hline & Lány & 62,9 & 11,3 & - & - & 3,2 & - & 22,6 \\
\hline & Összesen & 48,9 & 21,8 & 8,1 & 1,2 & 5,4 & 0,5 & 14,2 \\
\hline $\begin{array}{l}\text { 1936/1937 } \\
\text { gimnázium }\end{array}$ & Fiú & 37,5 & 41,5 & 4,8 & 4,0 & - & 1,2 & 10,9 \\
\hline
\end{tabular}

Az érettségi diplomát is adó állami felső kereskedelmi iskolákban az 1920-as évek elején 1000-1500 diák tanult, a későbbiekben viszont a számuk meghaladta a kétezret, vagy akár a négyezret is megközelítette. A továbbtanulási arány az évek folyamán hetvenhárom-nyolcvannyolc százalék között ingadozott, amely meghaladta az elemi szintü kereskedelmi iskolák mutatóit.

Erdélyben 5 állami, 7 községi, 2 egyesületi és 11 egyházi, azaz összesen 25 felső kereskedelmi iskola müködött az 1919/1920-as tanévben. Az egyháziakból ötöt a református, hármat az evangélikus, kettőt a római katolikus és egyet az izraelita felekezet müködtetett.

70. A felső kereskedelmi iskolák megoszlása fenntartók szerint, és a diákok száma 1919/1920-ban:

\begin{tabular}{|l|c|c|c|c|c|c|}
\hline \multirow{2}{*}{} & \multicolumn{3}{|c|}{ Iskolák száma } & \multicolumn{3}{c|}{ Tanerök } \\
\cline { 2 - 8 } & Fiú & Lány & Összesen & Fiúiskolák & Lányiskolák & Összesen \\
\hline Állami & 5 & - & 5 & 54 & - & 54 \\
\hline Községi & 4 & 3 & 7 & 52 & 23 & 75 \\
\hline Egyesületi & 1 & 1 & 2 & 18 & 10 & 28 \\
\hline
\end{tabular}




\begin{tabular}{|l|l|c|c|c|c|c|c|}
\hline \multirow{5}{*}{ Egyházi } & $\begin{array}{l}\text { Római } \\
\text { katolikus }\end{array}$ & - & 2 & 2 & - & 22 & 22 \\
\cline { 2 - 8 } & Református & 4 & 1 & 5 & 47 & 10 & 57 \\
\cline { 2 - 8 } & Evangélikus & 2 & 1 & 3 & 20 & 16 & 36 \\
\cline { 2 - 8 } & Izraelita & 1 & - & 1 & 14 & - & 14 \\
\cline { 2 - 7 } & $\begin{array}{l}\text { Összes } \\
\text { egyházi }\end{array}$ & 7 & 4 & 11 & 81 & 48 & 129 \\
\hline Összesen & 17 & 8 & 25 & 205 & 81 & 286 \\
\hline
\end{tabular}

Az állami iskolákat elsősorban a román diákok látogatták, míg a kisebbségekhez tartozó tanulók az anyanyelven oktató községi, egyesületi vagy az egyházak által fenntartott intézményekbe jártak. Ennek tulajdonítható az, hogy az állami kereskedelmikben a románok aránya 59,8\% volt, a községiekben viszont alig 7,3. A többi iskolatípusban elhanyagolható volt a számuk. Ha az összesített adatokat nézzük, akkor is szembetűnő a különbség. Az 1919/1920-as tanévben, azaz Erdély Romániához történő csatolását követő évben a felső kereskedelmi iskolák növendékeinek csak 12,5\%-a volt román. Ezzel szemben a magyarok 49,1\%-ot és a zsidók 26,7-et tettek ki.

71. A felső kereskedelmi iskolák diákjainak nemzetiségi megoszlása 1919/1920-ban:

\begin{tabular}{|c|c|c|c|c|c|c|c|c|c|c|c|c|}
\hline & \multicolumn{11}{|c|}{ Beiratkozott diákok nemzetisége } \\
\hline & & \multicolumn{2}{|c|}{ Román } & \multicolumn{2}{|c|}{ Német } & \multicolumn{2}{|c|}{ Magyar } & \multicolumn{2}{|c|}{ Zsidó } & \multicolumn{2}{|c|}{ Egyéb } & \multirow{2}{*}{$\begin{array}{c}\text { Össze- } \\
\text { sen }\end{array}$} \\
\hline & & & $\%$ & & $\%$ & & $\%$ & & $\%$ & & $\%$ & \\
\hline \multicolumn{2}{|c|}{ Állami } & 262 & 59,8 & 10 & 2,3 & 94 & 21,5 & 69 & 15,8 & 3 & 0,7 & 438 \\
\hline \multicolumn{2}{|c|}{ Községi } & 94 & 7,3 & 92 & 7,2 & 737 & 57,6 & 339 & 26,5 & 17 & 1,3 & 1279 \\
\hline \multicolumn{2}{|c|}{ Egyesületi } & 12 & 3,4 & 6 & 1,7 & 127 & 36,1 & 205 & 58,2 & 2 & 0,6 & 352 \\
\hline \multirow{5}{*}{ 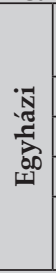 } & $\begin{array}{l}\text { Római } \\
\text { katolikus }\end{array}$ & 5 & 2,1 & 10 & 4,2 & 194 & 81,2 & 25 & 10,5 & 5 & 2,1 & 239 \\
\hline & Református & 4 & 0,8 & 47 & 10 & 335 & 71 & 80 & 16,9 & 6 & 1,3 & 472 \\
\hline & Evangélikus & 2 & 1,2 & 152 & 93,3 & 4 & 2,5 & - & - & 5 & 3,1 & 163 \\
\hline & Izraelita & - & - & - & - & 1 & 1,1 & 93 & 98,9 & - & - & 94 \\
\hline & \begin{tabular}{|l|}
$\begin{array}{l}\text { Összes } \\
\text { egyházi }\end{array}$ \\
\end{tabular} & 11 & 1,1 & 209 & 21,6 & 534 & 55,2 & 198 & 20,5 & 16 & 1,7 & 968 \\
\hline \multicolumn{2}{|c|}{ Összesen } & 379 & 12,5 & 317 & 10,4 & 1492 & 49,1 & 811 & 26,7 & 38 & 1,3 & 3037 \\
\hline
\end{tabular}

Az 1920-as évek elejétől az államosításoknak köszönhetően megnőtt az állami intézmények száma és jelentősége. Az állami és községi kereskedelmi iskolák is, hasonlóan a többi oktatási intézményhez, áttértek a román tanítási nyelvre, ennek eredményeként pedig fokozatosan növekedni kezdett a román nemzetiségú diákok aránya is (lásd bővebben a 20. sz. mellékletet). A növekedéshez ugyanakkor a román népesség városi lakosságon belül tapasztalható térnyerése is hozzájárult. A román állam, 
hasonlóan a többi oktatási területhez, a kereskedelmi oktatás területén is jelentős fejlesztést vitt véghez. Az intézmények számának növekedésével párhuzamosan a tanár-diák arányban is jelentős javulás érzékelhető. Az 1921/1922-es tanévben 10,6 tanuló jutott egy tanárra, 1936/1937-ben pedig csak 8,3. A beiratkozott diákok száma megkétszereződött a két világháború között.

72. Az állami felsőkereskedelmi iskolák diákjai és tanárai:

\begin{tabular}{|l|c|c|c|c|}
\hline & $\begin{array}{c}\text { Intézmények } \\
\text { száma }\end{array}$ & Beiratkozottak & $\begin{array}{c}\text { Felsőbb osztályba } \\
\text { léptek }\end{array}$ & $\begin{array}{c}\text { Tanárok } \\
\text { (mesterek nélkül) }\end{array}$ \\
\hline $\mathbf{1 9 2 1 / 1 9 2 2}$ & 13 & 1309 & 1100 & 123 \\
\hline $\mathbf{1 9 2 2 / 1 9 2 3}$ & 14 & 1181 & 994 & 91 \\
\hline $\mathbf{1 9 2 3 / 1 9 2 4}$ & 15 & 1456 & 1139 & 127 \\
\hline $\mathbf{1 9 2 4 / 1 9 2 5}$ & 18 & 2077 & 1561 & 134 \\
\hline $\mathbf{1 9 2 5 / 1 9 2 6}$ & 18 & 2613 & 2085 & 152 \\
\hline $\mathbf{1 9 2 6 / 1 9 2 7}$ & 19 & 3047 & 2405 & 207 \\
\hline $\mathbf{1 9 2 7 / 1 9 2 8}$ & 22 & 3393 & 2661 & 239 \\
\hline $\mathbf{1 9 2 8 / 1 9 2 9}$ & 20 & 3359 & 2648 & 305 \\
\hline $\mathbf{1 9 3 0 / 1 9 3 1}$ & 27 & 3901 & 3074 & 365 \\
\hline $\mathbf{1 9 3 1 / 1 9 3 2}$ & 22 & 3155 & 2644 & 252 \\
\hline $\mathbf{1 9 3 2 / 1 9 3 3}$ & 21 & 2328 & 2013 & 268 \\
\hline $\mathbf{1 9 3 5 / 1 9 3 6}$ & 22 & 1826 & 1372 & 352 \\
\hline $\mathbf{1 9 3 6 / 1 9 3 7}$ & 22 & 2951 & 2309 & \\
\hline líceum & & & & \\
\hline
\end{tabular}

Az állami felső kereskedelmi iskolák növendékeinek etnikai megoszlása eltért a hasonló profilú elemi szintű intézményekétől. Főként az első világháborút követő években tapasztalható a román diákok alulreprezentáltsága. Az 1921/1922-es tanévben például alig 26,5\%-ot tettek ki. A következő tanévtől viszont már meghaladták az ötven százalékot, és az arányuk fokozatosan növekedett az 1930-as évekig. Ettől az időponttól kezdődően újabb csökkenésnek lehetünk tanúi. Magas volt mindvégig a zsidó diákok száma, amely hasonló okokra vezethetô vissza, mint az elemi fokú kereskedelmi iskolák esetében (lásd bővebben a 21. sz. mellékletet).

73. Az állami felső kereskedelmi iskolák diákjainak nemzetiségi megoszlása:

\begin{tabular}{|c|c|c|c|c|c|c|c|c|c|c|c|}
\hline & \multicolumn{11}{|c|}{ Beiratkozott diákok nemzetisége } \\
\hline & \multicolumn{2}{|c|}{ Román } & \multicolumn{2}{|c|}{ Német } & \multicolumn{2}{|c|}{ Magyar } & \multicolumn{2}{|c|}{ Zsidó } & \multicolumn{2}{|c|}{ Egyéb } & \multirow{2}{*}{ Összesen } \\
\hline & & $\%$ & & $\%$ & & $\%$ & & $\%$ & & $\%$ & \\
\hline 1921/1922 & 347 & 26,5 & & & & & 185 & 14,1 & 777 & 59,4 & 1309 \\
\hline $1922 / 1923$ & 621 & 52,6 & & & & & 220 & 18,6 & 340 & 28,8 & 1181 \\
\hline $1923 / 1924$ & 845 & 58,0 & 91 & 6,3 & 265 & 18,2 & 236 & 16,2 & 19 & 1,3 & 1456 \\
\hline
\end{tabular}




\begin{tabular}{|l|l|l|l|l|l|l|l|l|l|l|l|}
\hline $\mathbf{1 9 2 4 / 1 9 2 5}$ & 1373 & 66,1 & 146 & 7,0 & 299 & 14,4 & 230 & 11,1 & 29 & 1,4 & 2077 \\
\hline $\mathbf{1 9 2 5 / 1 9 2 6}$ & 1915 & 73,3 & 157 & 6,0 & 318 & 12,2 & 197 & 7,5 & 26 & 1,0 & 2613 \\
\hline $\mathbf{1 9 2 6 / 1 9 2 7}$ & 2301 & 75,5 & 171 & 5,6 & 343 & 11,3 & 165 & 5,4 & 67 & 2,2 & 3047 \\
\hline $\mathbf{1 9 2 7 / 1 9 2 8}$ & 2559 & 75,4 & 212 & 6,2 & 404 & 11,9 & 179 & 5,3 & 39 & 1,1 & 3393 \\
\hline $\mathbf{1 9 2 8 / 1 9 2 9}$ & 2548 & 75,9 & 215 & 6,4 & 384 & 11,4 & 181 & 5,4 & 31 & 0,9 & 3359 \\
\hline $\mathbf{1 9 3 5 / 1 9 3 6}$ & 1169 & 64,0 & 122 & 6,7 & 327 & 17,9 & 181 & 9,9 & 27 & 1,5 & 1826 \\
\hline $\begin{array}{l}\mathbf{1 9 3 6 / 1 9 3 7} \\
\text { líceum }\end{array}$ & 1912 & 64,8 & 190 & 6,4 & 453 & 15,4 & 368 & 12,5 & 28 & 0,9 & 2951 \\
\hline
\end{tabular}

Az állami felső kereskedelmi iskolákban a görögkeletiek és a görög katolikusok alkották a többséget. A 73. sz. táblázatban közölt etnikai arányoknak megfelelően a két román valláshoz tartozó gyermekek aránya itt is alacsonyabb volt a kezdeti években (lásd bővebben a 22-23. sz. mellékleteket). A felekezeti megoszlás azt mutatja, hogy az ortodox, unitárius és az izraelita felekezethez tartozó diákok felülreprezentáltak voltak a felső kereskedelmisták között, az egyéb vallásúak pedig alulreprezentáltak. Mint már többször tettük a dolgozatunk folyamán, az izraelita növendékek magas számánál újból a zsidó lakosság foglalkozásszerkezetére és előrehaladottabb modernizációs, urbanizáltsági szintjére kell utalnunk.

A diákok vallási megoszlásának dinamikáját nagyban befolyásolták a kereskedelmi iskolák tulajdonosai terén bekövetkezett változások és a helyszín. Ezeknek az intézményeknek az államosítása vagy létesítése lépésenként történt 1918 után. Az 1921/1922-as tanévben például a már meglévő állami intézmények mellett hat felső kereskedelmi iskola államosítására került sor: Aradon egy fiú és egy leány kereskedelmi, Brassóban, Szatmárnémetiben, Nagyszebenben és Temesváron. Ha megnézzük ezeknek a városoknak a felekezeti összetételét, akkor azt látjuk, hogy a görögkeletiek száma, Szatmárnémetit kivéve, mindenhol messze felülmúlta a görög katolikusokét. Természetes tehát, hogy ez a számbeli különbség a kereskedelmi iskolák diákjainak körében is leképződött, és ez a későbbi években sem változott. Az unitárius növendékek felülreprezentáltsága és az evangélikusok térvesztése hasonló okokra vezethető vissza. Az intézmények többsége olyan településen múködött, ahol több vagy közel azonos számú evangélikus élt, mint unitárius. Az unitárius egyház viszont nem működtetett saját felső kereskedelmi iskolát (lásd a 76. sz. táblázatot), így a gyermekeik nagyobb arányban választották az állami iskolákat, mint az evangélikusok (Anuarul Învățământului Comercial 1927: XXII-XXVI). 
74. Az állami felső kereskedelmi iskolákba beiratkozott növendékek felekezeti megoszlása:

\begin{tabular}{|c|c|c|c|c|c|c|c|c|c|}
\hline & \multicolumn{9}{|c|}{ Beiratkozott növendékek felekezete } \\
\hline & 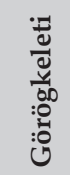 & 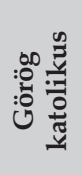 & 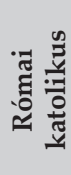 & 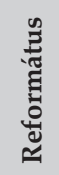 & & 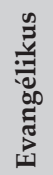 & 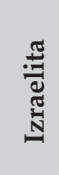 & $\overbrace{0.01}^{00}$ & 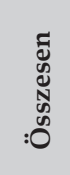 \\
\hline 1921/1922 & 356 & 26 & & & & & 185 & 742 & 1309 \\
\hline $1922 / 1923$ & 514 & 43 & & & & & 220 & 404 & 1181 \\
\hline $1923 / 1924$ & 720 & 120 & 230 & 12 & 100 & 34 & 236 & 4 & 1456 \\
\hline 1924/1925 & 1117 & 235 & 314 & 24 & 100 & 51 & 230 & 6 & 2077 \\
\hline 1925/1926 & 1540 & 355 & 341 & 13 & 106 & 46 & 197 & 15 & 2613 \\
\hline $1926 / 1927$ & 1860 & 443 & 358 & 15 & 148 & 40 & 165 & 18 & 3047 \\
\hline $1927 / 1928$ & 2080 & 485 & 436 & 21 & 140 & 46 & 179 & 6 & 3393 \\
\hline $1928 / 1929$ & 2014 & 536 & 437 & 105 & 38 & 46 & 181 & 2 & 3359 \\
\hline \begin{tabular}{|l|}
$1930 / 1931$ \\
\end{tabular} & 2259 & 678 & 490 & 14 & 168 & 35 & 253 & 4 & 3901 \\
\hline $1931 / 1932$ & 1814 & 562 & 386 & 8 & 130 & 50 & 198 & 7 & 3155 \\
\hline \begin{tabular}{|l|}
$1932 / 1933$ \\
\end{tabular} & 1269 & 410 & 301 & 6 & 110 & 38 & 178 & 16 & 2328 \\
\hline \begin{tabular}{|l|}
$1935 / 1936$ \\
\end{tabular} & 873 & 287 & 302 & 11 & 125 & 40 & 181 & 7 & 1826 \\
\hline $\begin{array}{l}\text { 1936/1937 } \\
\text { líceum }\end{array}$ & 1358 & 538 & 396 & 197 & 24 & 64 & 368 & 6 & 2951 \\
\hline
\end{tabular}

75. Az állami felső kereskedelmi iskolákba beiratkozott növendékek felekezeti megoszlása, százalékban kifejezve:

\begin{tabular}{|c|c|c|c|c|c|c|c|}
\hline & \multicolumn{7}{|c|}{ Beiratkozott növendékek felekezete } \\
\hline & 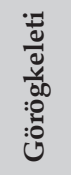 & 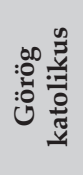 & 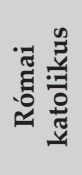 & 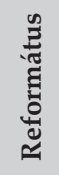 & 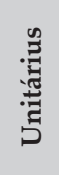 & 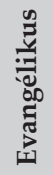 & 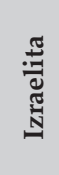 \\
\hline 1921/1922 & 27,2 & 2,0 & & & & & 14,1 \\
\hline 1922/1923 & 43,5 & 3,6 & & & & & 18,6 \\
\hline $1923 / 1924$ & 49,5 & 8,2 & 15,8 & 0,8 & 6,9 & 2,3 & 16,2 \\
\hline $1924 / 1925$ & 53,8 & 11,3 & 15,1 & 1,2 & 4,8 & 2,5 & 11,1 \\
\hline $1925 / 1926$ & 58,9 & 13,6 & 13,1 & 0,5 & 4,1 & 1,8 & 7,5 \\
\hline $1926 / 1927$ & 61,0 & 14,5 & 11,7 & 0,5 & 4,9 & 1,3 & 5,4 \\
\hline $1927 / 1928$ & 61,3 & 14,3 & 12,8 & 0,6 & 4,1 & 1,4 & 5,3 \\
\hline $1928 / 1929$ & 60,0 & 16,0 & 13,0 & 3,1 & 1,1 & 1,4 & 5,4 \\
\hline $1930 / 1931$ & 57,9 & 17,4 & 12,6 & 0,4 & 4,3 & 0,9 & 6,5 \\
\hline 1931/1932 & 57,5 & 17,8 & 12,2 & 0,3 & 4,1 & 1,6 & 6,3 \\
\hline $1932 / 1933$ & 54,5 & 17,6 & 12,9 & 0,3 & 4,7 & 1,6 & 7,6 \\
\hline $1935 / 1936$ & 47,8 & 15,7 & 16,5 & 0,6 & 6,8 & 2,2 & 9,9 \\
\hline $\begin{array}{l}\text { 1936/1937 } \\
\text { líceum }\end{array}$ & 46,0 & 18,2 & 13,4 & 6,7 & 0,8 & 2,2 & 12,5 \\
\hline
\end{tabular}


Felső kereskedelmi iskolát a római katolikus, református, evangélikus és izraelita felekezetek működtettek az 1920-as évek második felében. 1926/1927-ben összesen 6 felekezeti és 5 egyesületi, a két utána következő tanévben pedig 6-6, illetve 2-2 hasonló jellegü iskola működött. Ezeknek az intézményeknek a befogadóképessége viszont jóval csekélyebb volt, mint az államiaké, így lényegesen kevesebb diák tanulhatott itt. Az 1928/1929-es tanévben például az egyházi vagy magántulajdonban lévő felsőkereskedelmi iskolák 28,6\%-ot tettek ki, de az összdiákságnak csak 20,8\%-a felett rendelkeztek.

76. Az egyházi és egyesületi felső kereskedelmi iskolák, valamint a tanáraik száma:

\begin{tabular}{|c|c|c|c|c|c|c|c|c|}
\hline & & 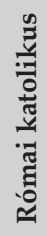 & 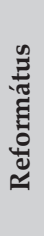 & 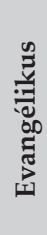 & 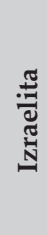 & 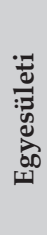 & 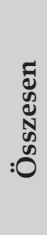 & 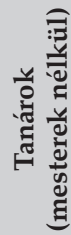 \\
\hline \multirow{3}{*}{$1926 / 1927$} & Fiú & - & 1 & 1 & 1 & 4 & 7 & 72 \\
\hline & Lány & 2 & 1 & - & - & 1 & 4 & 51 \\
\hline & Összesen & 2 & 2 & 1 & 1 & 5 & 11 & 123 \\
\hline \multirow{3}{*}{$1927 / 1928$} & Fiú & - & 1 & 1 & 1 & 1 & 4 & 55 \\
\hline & Lány & 2 & 1 & - & - & 1 & 4 & 47 \\
\hline & Összesen & 2 & 2 & 1 & 1 & 2 & 8 & 102 \\
\hline \multirow{3}{*}{$1928 / 1929$} & Fiú & - & 1 & 1 & 1 & 1 & 4 & 50 \\
\hline & Lány & 2 & 1 & - & - & 1 & 4 & 51 \\
\hline & Összesen & 2 & 2 & 1 & 1 & 2 & 8 & 101 \\
\hline
\end{tabular}

Az 1926/1927-es tanévre 1381 diák iratkozott be és 85,2\%-uk lépett felsőbb osztályba. A továbbtanulók aránya a következő két évben is meglehetősen magas, azaz 87,5 és $87,3 \%$ volt, amely jelentősen meghaladta az állami fenntartású felsőkereskedelmi iskolák 1926-1928 közötti mutatóit (78,4-78,9\% közötti arányok).

77. Az egyházi és egyesületi felsókereskedelmi iskolák diákjai:

\begin{tabular}{|c|l|c|c|c|}
\hline \multicolumn{2}{|c|}{} & $\begin{array}{c}\text { Intézmények } \\
\text { száma }\end{array}$ & $\begin{array}{c}\text { Beiratkozott } \\
\text { diákok }\end{array}$ & $\begin{array}{c}\text { Felsőbb osztályba } \\
\text { léptek }\end{array}$ \\
\hline \multirow{3}{*}{$1926 / 1927$} & 7 & 1075 & 891 \\
\cline { 2 - 5 } & Fiú & 4 & 306 & 286 \\
\cline { 2 - 5 } & Ö́sszesen & 11 & 1381 & 1177 \\
\hline \multirow{3}{*}{$1927 / 1928$} & Fiú & 4 & 520 & 448 \\
\cline { 2 - 5 } & Lány & 4 & 334 & 299 \\
\cline { 2 - 5 } & Összesen & 8 & 854 & 747 \\
\hline
\end{tabular}




\begin{tabular}{|c|l|l|l|l|}
\hline \multirow{3}{*}{ 1928/1929 } & Fiú & 4 & 511 & 433 \\
\cline { 2 - 5 } & Lány & 4 & 371 & 337 \\
\cline { 2 - 5 } & Összesen & 8 & 882 & 770 \\
\hline
\end{tabular}

A nem állami felső kereskedelmi iskolák tanulóinak többsége a három legnagyobb létszámmal rendelkező erdélyi etnikum, a magyarok, a németek és a zsidók közül került ki. 1926/1927-ben a beiratkozott növendékeknek negyven százaléka volt német, harminchárom százaléka magyar és húsz százaléka zsidó, míg a románok csak hét százalékot tettek ki. A következő két évben a németek és a románok aránya is csökkent, míg a magyaroké és a zsidóké emelkedett.

78. Az egyházi és egyesületi felső kereskedelmi iskolák diákjainak nemzetiségi megoszlása:

\begin{tabular}{|c|c|c|c|c|c|c|c|c|c|c|c|}
\hline & \multicolumn{10}{|c|}{ Beiratkozott diákok nemzetisége } \\
\hline & & \multicolumn{2}{|c|}{ Román } & \multicolumn{2}{|c|}{ Német } & \multicolumn{2}{|c|}{ Magyar } & \multicolumn{2}{|c|}{ Zsidó } & \multirow{2}{*}{ Egyéb } & \multirow{2}{*}{$\begin{array}{c}\text { Össze- } \\
\text { sen }\end{array}$} \\
\hline & & & $\%$ & & $\%$ & & $\%$ & & $\%$ & & \\
\hline \multirow{3}{*}{$1926 / 1927$} & Fiú & 89 & 8,3 & 553 & 51,4 & 191 & 17,8 & 242 & 22,5 & - & 1075 \\
\hline & Lány & 1 & 0,3 & 2 & 0,7 & 267 & 87,3 & 34 & 11,1 & 4 & 306 \\
\hline & Összesen & 90 & 6,5 & 555 & 40,2 & 458 & 33,2 & 276 & 20,0 & 4 & 1381 \\
\hline \multirow{3}{*}{$1927 / 1928$} & Fiú & 43 & 8,3 & 114 & 21,9 & 136 & 26,2 & 227 & 43,7 & - & 520 \\
\hline & Lány & 1 & 0,3 & 1 & 0,3 & 303 & 90,7 & 26 & 7,8 & 3 & 334 \\
\hline & Összesen & 44 & 5,2 & 115 & 13,5 & 439 & 51,4 & 253 & 29,6 & 3 & 854 \\
\hline \multirow{3}{*}{$1928 / 1929$} & Fiú & 34 & 6,7 & 135 & 26,4 & 132 & 25,8 & 210 & 41,1 & - & 511 \\
\hline & Lány & 4 & 1,1 & - & 0,0 & 331 & 89,2 & 35 & 9,4 & 1 & 371 \\
\hline & Összesen & 38 & 4,3 & 135 & 15,3 & 463 & 52,5 & 245 & 27,8 & 1 & 882 \\
\hline
\end{tabular}

A felekezeti megoszlás tekintetében hasonló eredményeket kapunk. Mivel a görögkeleti és görög katolikus egyház nem tartott fenn felső kereskedelmi iskolákat, a diákok túlnyomó többsége római katolikus, evangélikus, izraelita és református volt.

79. Az egyházi és egyesületi felső kereskedelmi iskolák diákjainak felekezeti megoszlása:

\begin{tabular}{|c|c|c|c|c|c|c|c|c|c|c|}
\hline & \multicolumn{9}{|c|}{ Beiratkozottak vallása } \\
\hline & & 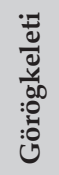 & 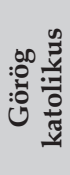 & 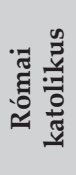 & 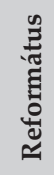 & & 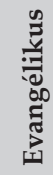 & 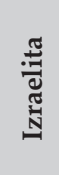 & 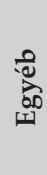 & 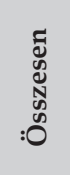 \\
\hline \multirow{3}{*}{$1926 / 1927$} & Fiú & 69 & 21 & 148 & 78 & 5 & 512 & 242 & - & 1075 \\
\hline & Lány & 1 & 3 & 159 & 85 & 9 & 15 & 34 & - & 306 \\
\hline & Összesen & 70 & 24 & 307 & 163 & 14 & 527 & 276 & - & 1381 \\
\hline
\end{tabular}




\begin{tabular}{|c|l|c|c|c|c|c|c|c|c|c|}
\hline \multirow{3}{*}{ 1927/1928 } & Fiú & 30 & 13 & 82 & 53 & 1 & 114 & 227 & - & 520 \\
\cline { 2 - 11 } & Lány & 1 & 3 & 160 & 117 & 11 & 16 & 26 & - & 334 \\
\cline { 2 - 11 } & Összesen & 31 & 16 & 242 & 170 & 12 & 130 & 253 & - & 854 \\
\hline \multirow{3}{*}{$1928 / 1929$} & Fiú & 24 & 10 & 87 & 48 & 1 & 130 & 210 & 1 & 511 \\
\cline { 2 - 11 } & Lány & 4 & - & 184 & 121 & 13 & 14 & 35 & - & 371 \\
\cline { 2 - 10 } & Összesen & 28 & 10 & 271 & 169 & 14 & 144 & 245 & 1 & 882 \\
\hline
\end{tabular}

80. Az egyházi és egyesületi felső kereskedelmi iskolák diákjainak felekezeti megoszlása, százalékban kifejezve:

\begin{tabular}{|c|c|c|c|c|c|c|c|c|}
\hline & \multicolumn{7}{|c|}{ Beiratkozottak vallása } \\
\hline & & 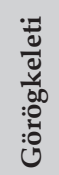 & 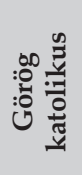 & 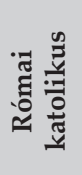 & 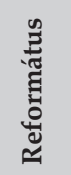 & & 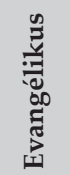 & 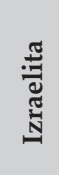 \\
\hline \multirow{3}{*}{$1926 / 1927$} & Fiú & 6,4 & 2,0 & 13,8 & 7,3 & 0,5 & 47,6 & 22,5 \\
\hline & Lány & 0,3 & 1,0 & 52,0 & 27,8 & 2,9 & 4,9 & 11,1 \\
\hline & Összesen & 5,1 & 1,7 & 22,2 & 11,8 & 1,0 & 38,2 & 20,0 \\
\hline \multirow{3}{*}{$1927 / 1928$} & Fiú & 5,8 & 2,5 & 15,8 & 10,2 & 0,2 & 21,9 & 43,7 \\
\hline & Lány & 0,3 & 0,9 & 47,9 & 35,0 & 3,3 & 4,8 & 7,8 \\
\hline & Összesen & 3,6 & 1,9 & 28,3 & 19,9 & 1,4 & 15,2 & 29,6 \\
\hline \multirow{3}{*}{$1928 / 1929$} & Fiú & 4,7 & 2,0 & 17,0 & 9,4 & 0,2 & 25,4 & 41,1 \\
\hline & Lány & 1,1 & - & 49,6 & 32,6 & 3,5 & 3,8 & 9,4 \\
\hline & Összesen & 3,2 & 1,1 & 30,7 & 19,2 & 1,6 & 16,3 & 27,8 \\
\hline
\end{tabular}

\subsubsection{Ipariskolák, szakiskolák és háztartási iskolák}

A gyakorlati, szakmai képzést az állam által fenntartott szakiskolák, ipariskolák és háztartási iskolák biztosították. Az ezekből az intézményekből kikerülő növendékek túlnyomó többsége a szakmunkás-, illetve a munkásrétegbe tagozódott be.

A két világháború közötti román állami iskolafejlesztés területén, az óvodák és a gimnáziumok mellett a szakoktatást biztosító intézmények (ipariskolák, szakiskolák, háztartási és mezőgazdasági iskolák) fejlődése a legszembetünőbb. 1919-et követően az utóbbi iskolatípusok száma megháromszorozódott, és lényeges jellemzőjük volt, hogy elsősorban román diákok tanultak a falaik között. Ez a fejlődés lényegében a Regátban már a 19. század végén megkezdett iskolapolitikát folytatta, amikor fokozott hangsúlyt fektettek a gyakorlati szakmákat nyújtó iskolák létrehozására és fejlesztésére. 
Az első világháború utáni Erdélyben az ipari oktatást az elemi szintü, valamint az alsó és felsőfokú ipariskolák biztosították. Elemi ipari iskolából csak egy volt a régióban és 1937-ig müködött. Az itt tanuló diákok kizárólag románok voltak, és a görögkeleti vagy a görög katolikus vallást követték.

81. Az állami elemi ipariskolák diákjai és tanárai:

\begin{tabular}{|c|c|c|c|c|c|c|}
\hline & \multirow{2}{*}{ 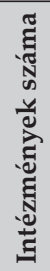 } & \multirow{2}{*}{ 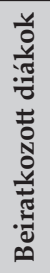 } & \multirow{2}{*}{ 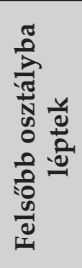 } & \multicolumn{2}{|c|}{$\begin{array}{l}\text { Beiratkozott diákok } \\
\text { nemzetisége }\end{array}$} & \multirow{2}{*}{ 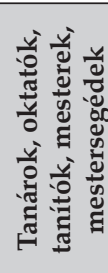 } \\
\hline & & & & Román & Összesen & \\
\hline $1928 / 1929$ & 1 & 23 & 19 & 23 & 23 & 4 \\
\hline $1930 / 1931$ & 1 & 29 & 29 & 29 & 29 & 5 \\
\hline $\begin{array}{l}\text { 1936/1937 ipari } \\
\text { mühelyek fiúknak }\end{array}$ & 1 & 12 & $?$ & 12 & 12 & 6 \\
\hline
\end{tabular}

Az alsó fokú ipariskolák száma 1923-tól ugrott tehát meg. Ekkor 20, a következő tanévben pedig - Angelescu közoktatásügyi miniszter iskolaépítési akciójának köszönhetően - már 29 müködött Erdélyben. A tanulók létszáma is ennek megfelelően 1000-3000 között mozgott. A felsőbb osztályba lépők aránya, 1921-et leszámítva, megközelítette vagy meghaladta a nyolcvan százalékot.

82. Az alsó fokú állami ipariskolák diákjai és tanárai:

\begin{tabular}{|l|l|c|c|c|c|}
\hline \multicolumn{2}{|l|}{} & $\begin{array}{c}\text { Intézmények } \\
\text { száma }\end{array}$ & $\begin{array}{c}\text { Beiratkozott } \\
\text { diákok }\end{array}$ & $\begin{array}{c}\text { Felsőbb } \\
\text { osztályba } \\
\text { léptek }\end{array}$ & $\begin{array}{c}\text { Tanárok, oktatók, } \\
\text { tanítók, mesterek, } \\
\text { mestersegédek }\end{array}$ \\
\hline $\mathbf{1 9 1 9 / 1 9 2 0}$ & Fiú & 9 & 551 & $?$ & 50 \\
\hline $\mathbf{1 9 2 1 / 1 9 2 2}$ & Fiú & 11 & 2639 & 1639 & 176 \\
\hline $\mathbf{1 9 2 2 / 1 9 2 3}$ & Fiú & 12 & 1206 & 999 & 140 \\
\hline $\mathbf{1 9 2 3 / 1 9 2 4}$ & Fiú & 20 & 1410 & 1203 & 190 \\
\hline $\mathbf{1 9 2 4 / 1 9 2 5}$ & Fiú & 29 & 1784 & 1477 & 238 \\
\hline $\mathbf{1 9 2 5 / 1 9 2 6}$ & Fiú & 35 & 2294 & 1926 & 328 \\
\hline $\mathbf{1 9 2 6 / 1 9 2 7}$ & Fiú & 38 & 2791 & 2285 & 446 \\
\hline $\mathbf{1 9 2 7 / 1 9 2 8}$ & Fiú & 38 & 2802 & 2356 & 342 \\
\hline $\mathbf{1 9 2 8 / 1 9 2 9}$ & Fiú & 36 & 2967 & 2506 & 339 \\
\hline $\mathbf{1 9 3 0 / 1 9 3 1}$ & Fiú & 31 & 2467 & 2082 & 373 \\
\hline $\mathbf{1 9 3 1 / 1 9 3 2}$ & Fiú & 25 & 1724 & 1428 & 285 \\
\hline $\mathbf{1 9 3 2 / 1 9 3 3}$ & Fiú & 22 & 1341 & 1064 & 273 \\
\hline $\mathbf{1 9 3 5 / 1 9 3 6}$ & Fiú & 19 & 979 & 789 & 200 \\
\hline
\end{tabular}




\begin{tabular}{|l|l|c|c|c|c|}
\hline \multirow{2}{*}{$\begin{array}{l}\text { 1936/1937 } \\
\text { ipari gimná- } \\
\text { zium }\end{array}$} & Fiú & 18 & 1533 & 1210 & 210 \\
\cline { 2 - 6 } & Lány & 6 & 537 & 407 & 85 \\
\cline { 2 - 6 } & Összesen & 24 & 2070 & 1617 & 295 \\
\hline
\end{tabular}

Az alsó fokú ipariskolák tanulóinak nagy részét a román nemzetiségüek alkották, a kisebbségi diákok alulreprezentáltak voltak. A jelenség főként az 1920-as évek közepétől figyelhető meg. A világháború utáni első években ugyanis még a magyar és német növendékek alkották a többséget. 1922-ben viszont már a beiratkozottaknak hetvenöt százaléka, 1923-ban nyolcvannégy és 1924-ben kilencven százaléka volt román. Az etnikai arányok megváltozásában a magyar tanítási nyelvről a románra történő átállás játszhatott szerepet.

83. Az alsó fokú állami ipariskolák diákjainak nemzetiségi megoszlása:

\begin{tabular}{|c|c|c|c|c|c|c|c|c|c|c|c|c|}
\hline & \multicolumn{11}{|c|}{ Beiratkozott diákok nemzetisége } \\
\hline & & \multicolumn{2}{|c|}{ Román } & \multicolumn{2}{|c|}{ Német } & \multicolumn{2}{|c|}{ Magyar } & \multicolumn{2}{|c|}{ Zsidó } & \multicolumn{2}{|c|}{ Egyéb } & \multirow{2}{*}{$\begin{array}{c}\text { Össze } \\
\text { sen }\end{array}$} \\
\hline & & & $\%$ & & $\%$ & & $\%$ & & $\%$ & & $\%$ & \\
\hline $1919 / 1920$ & Fiú & 201 & 36,5 & 11 & 2,0 & 313 & 56,8 & 22 & 4,0 & 4 & 0,7 & 551 \\
\hline $1921 / 1922$ & Fiú & 888 & 33,6 & & & & & 16 & 0,6 & & & 2639 \\
\hline $1922 / 1923$ & Fiú & 904 & 75,0 & & & & & 12 & 1,0 & & & 1206 \\
\hline $1923 / 1924$ & Fiú & 1184 & 84,0 & 48 & 3,4 & 143 & 10,1 & 12 & 0,9 & 23 & 1,6 & 1410 \\
\hline $1924 / 1925$ & Fiú & 1619 & 90,8 & 31 & 1,7 & 113 & 6,3 & 14 & 0,8 & 7 & 0,4 & 1784 \\
\hline $1925 / 1926$ & Fiú & 2105 & 91,8 & 34 & 1,5 & 127 & 5,5 & 8 & 0,3 & 20 & 0,9 & 2294 \\
\hline $1926 / 1927$ & Fiú & 2553 & 91,5 & 44 & 1,6 & 155 & 5,6 & 17 & 0,6 & 22 & 0,8 & 2791 \\
\hline $1927 / 1928$ & Fiú & 2550 & 91,0 & 56 & 2,0 & 156 & 5,6 & 14 & 0,5 & 26 & 0,9 & 2802 \\
\hline $1928 / 1929$ & Fiú & 2737 & 92,2 & 53 & 1,8 & 135 & 4,6 & 10 & 0,3 & 32 & 1,1 & 2967 \\
\hline $1935 / 1936$ & Fiú & 822 & 84,0 & 19 & 1,9 & 112 & 11,4 & 13 & 1,3 & 13 & 1,3 & 979 \\
\hline \multirow{3}{*}{$\begin{array}{l}\text { 1936/1937 } \\
\text { ipari gim- } \\
\text { názium }\end{array}$} & Fiú & 1152 & 75,1 & 64 & 4,2 & 190 & 12,4 & 16 & 1,0 & 111 & 7,2 & 1533 \\
\hline & Lány & 420 & 78,2 & 13 & 2,4 & 61 & 11,4 & 26 & 4,8 & \begin{tabular}{|l|}
17 \\
\end{tabular} & 3,2 & 537 \\
\hline & Összesen & 1572 & 75,9 & 77 & 3,7 & 251 & 12,1 & 42 & 2,0 & 128 & 6,2 & 2070 \\
\hline
\end{tabular}

Az etnikai arányok eltolódásához hasonló jelenség figyelhető meg a felekezeti megoszlás terén is. Az 1921/1922-es tanévben a görögkeleti diákok 22,8\%-ot alkottak, a következő években viszont már több mint felét tették ki a növendékeknek. 
84. Az alsó fokú állami ipariskolák diákjainak felekezeti megoszlása:

\begin{tabular}{|c|c|c|c|c|c|c|c|c|c|c|}
\hline & \multicolumn{9}{|c|}{ Beiratkozott diákok vallása } \\
\hline & & \multirow{2}{*}{ 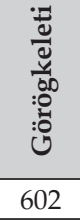 } & 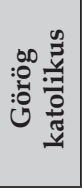 & 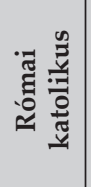 & 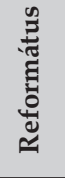 & & 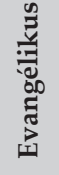 & \multirow{2}{*}{ 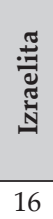 } & \multirow{2}{*}{ 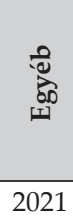 } & \multirow{2}{*}{ 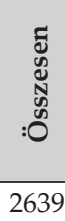 } \\
\hline $1921 / 1922$ & Fiú & & & & & & & & & \\
\hline 1922/1923 & Fiú & 762 & & & & & & 12 & 432 & 1206 \\
\hline 1923/1924 & Fiú & 711 & 470 & 138 & 2 & 60 & 13 & 12 & 4 & 1410 \\
\hline $1924 / 1925$ & Fiú & 996 & 615 & 98 & 8 & 45 & 8 & 14 & - & 1784 \\
\hline $1925 / 1926$ & Fiú & 1259 & 846 & 115 & 10 & 41 & 3 & 8 & 12 & 2294 \\
\hline 1926/1927 & Fiú & 1567 & 977 & 138 & 4 & 69 & 7 & 17 & 12 & 2791 \\
\hline $1927 / 1928$ & Fiú & 1538 & 1024 & 153 & 2 & 64 & 6 & 14 & 1 & 2802 \\
\hline $1928 / 1929$ & Fiú & 1781 & 943 & 174 & 6 & 42 & 5 & 10 & 6 & 2967 \\
\hline $1930 / 1931$ & Fiú & 1494 & 734 & 159 & 3 & 60 & 10 & 4 & 3 & 2467 \\
\hline 1931/1932 & Fiú & 975 & 504 & 140 & 3 & 77 & 15 & 10 & - & 1724 \\
\hline 1932/1933 & Fiú & 714 & 396 & 120 & 81 & 6 & 12 & 11 & 1 & 1341 \\
\hline $1935 / 1936$ & Fiú & 536 & 293 & 79 & 41 & 6 & 5 & 13 & 6 & 979 \\
\hline \multirow{3}{*}{$\begin{array}{l}\text { 1936/1937 } \\
\text { ipari gim- } \\
\text { názium }\end{array}$} & Fiú & 799 & 432 & 177 & 8 & 87 & 8 & 16 & 6 & 1533 \\
\hline & Lány & 336 & 80 & 52 & 3 & 26 & 14 & 26 & - & 537 \\
\hline & Összesen & 1135 & 512 & 229 & 11 & 113 & 22 & 42 & 6 & 2070 \\
\hline
\end{tabular}

85. Az alsó fokú állami ipariskolák diákjainak felekezeti megoszlása, százalékban kifejezve:

\begin{tabular}{|c|c|c|c|c|c|c|c|c|}
\hline & & & & eiratk & It diá & vallá & & \\
\hline & & $\begin{array}{l}: \\
0 \\
0 \\
0 \\
00 \\
: 00 \\
: 0 \\
0 \\
0\end{array}$ & 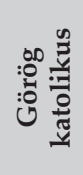 & 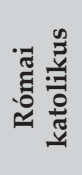 & 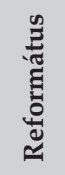 & & 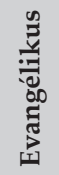 & 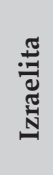 \\
\hline \begin{tabular}{|l}
$1921 / 1922$ \\
\end{tabular} & Fiú & 22,8 & & & & & & 0,6 \\
\hline \begin{tabular}{|l|}
$1922 / 1923$ \\
\end{tabular} & Fiú & 63,2 & & & & & & 1,0 \\
\hline 1923/1924 & Fiú & 50,4 & 33,3 & 9,8 & 0,1 & 4,3 & 0,9 & 0,9 \\
\hline \begin{tabular}{|l|}
$1924 / 1925$ \\
\end{tabular} & Fiú & 55,8 & 34,5 & 5,5 & 0,4 & 2,5 & 0,4 & 0,8 \\
\hline $1925 / 1926$ & Fiú & 54,9 & 36,9 & 5,0 & 0,4 & 1,8 & 0,1 & 0,3 \\
\hline $1926 / 1927$ & Fiú & 56,1 & 35,0 & 4,9 & 0,1 & 2,5 & 0,3 & 0,6 \\
\hline $1927 / 1928$ & Fiú & 54,9 & 36,5 & 5,5 & 0,1 & 2,3 & 0,2 & 0,5 \\
\hline $1928 / 1929$ & Fiú & 60,0 & 31,8 & 5,9 & 0,2 & 1,4 & 0,2 & 0,3 \\
\hline $1930 / 1931$ & Fiú & 60,6 & 29,8 & 6,4 & 0,1 & 2,4 & 0,4 & 0,2 \\
\hline 1931/1932 & Fiú & 56,6 & 29,2 & 8,1 & 0,2 & 4,5 & 0,9 & 0,6 \\
\hline $1932 / 1933$ & Fiú & 53,2 & 29,5 & 8,9 & 6,0 & 0,4 & 0,9 & 0,8 \\
\hline $1935 / 1936$ & Fiú & 54,7 & 29,9 & 8,1 & 4,2 & 0,6 & 0,5 & 1,3 \\
\hline
\end{tabular}




\begin{tabular}{|l|l|c|c|c|c|c|c|c|}
\hline $\begin{array}{l}\text { 1936/1937 } \\
\text { ipari gim- } \\
\text { názium }\end{array}$ & Fiú & 52,1 & 28,2 & 11,5 & 0,5 & 5,7 & 0,5 & 1,0 \\
\cline { 2 - 9 } & Lány & 62,6 & 14,9 & 9,7 & 0,6 & 4,8 & 2,6 & 4,8 \\
\cline { 2 - 9 } & Összesen & 54,8 & 24,7 & 11,1 & 0,5 & 5,5 & 1,1 & 2,0 \\
\hline
\end{tabular}

Felsőfokú állami ipariskolák az 1930-as évektől kezdődően működtek nagyobb számban, az 1936/1937-es tanévben pedig leány-ipariskola is nyílt Erdélyben. A felsőbb osztályba továbblépők aránya változó volt az évek folyamán, arányuk 73-91\% között ingadozott.

86. A felső fokú állami ipariskolák diákjainak és tanárainak száma:

\begin{tabular}{|l|l|c|c|c|c|}
\hline \multicolumn{2}{|l|}{} & $\begin{array}{c}\text { Intézmények } \\
\text { száma }\end{array}$ & $\begin{array}{c}\text { Beiratkozott } \\
\text { diákok }\end{array}$ & $\begin{array}{c}\text { Felsőbb } \\
\text { osztályba } \\
\text { léptek }\end{array}$ & $\begin{array}{c}\text { Tanárok, oktatók, } \\
\text { tanítók, mesterek, } \\
\text { mestersegédek }\end{array}$ \\
\hline $\mathbf{1 9 1 9 / 1 9 2 0}$ & Fiú & 2 & 329 & $?$ & 17 \\
\hline $\mathbf{1 9 2 7 / 1 9 2 8}$ & Fiú & 1 & 218 & 169 & 33 \\
\hline $\mathbf{1 9 2 8 / 1 9 2 9}$ & Fiú & 1 & 66 & 55 & 34 \\
\hline $\mathbf{1 9 3 0 / 1 9 3 1}$ & Fiú & 3 & 405 & 348 & 58 \\
\hline $\mathbf{1 9 3 1 / 1 9 3 2}$ & Fiú & 5 & 571 & 508 & 89 \\
\hline $\mathbf{1 9 3 2 / 1 9 3 3}$ & Fiú & 5 & 509 & 465 & 79 \\
\hline $\mathbf{1 9 3 5 / 1 9 3 6}$ & Fiú & 10 & 1360 & 1038 & 202 \\
\hline \multirow{1}{\mathbf{1936/1937}}{$\begin{array}{l}\text { ipari } \\
\text { líceum }\end{array}$} & Fiú & 8 & 1182 & 1021 & 173 \\
\cline { 2 - 6 } & Lány & 5 & 903 & 661 & 104 \\
\hline
\end{tabular}

Etnikai és vallási tekintetben a felsőfokú ipariskolák diákjainak megoszlása hasonlított az alsó fokú intézményekéhez. 1919/1920-ban itt is a kisebbségek és a kisebbségi felekezetekhez tartozó növendékek alkották a többséget. A későbbiekben viszont erőteljes arányeltolódás figyelhető meg a román diákok, illetve a görögkeletiek és görög katolikusok irányába.

87. A felső fokú állami ipariskolák növendékeinek nemzetiségi megoszlása:

\begin{tabular}{|c|c|c|c|c|c|c|c|c|c|c|c|}
\hline & \multicolumn{10}{|c|}{ Beiratkozott diákok nemzetisége } \\
\hline & & \multicolumn{2}{|c|}{ Román } & \multicolumn{2}{|c|}{ Német } & \multicolumn{2}{|c|}{ Magyar } & \multicolumn{2}{|c|}{ Zsidó } & \multirow{2}{*}{ Egyéb } & \multirow{2}{*}{$\begin{array}{c}\text { Össze- } \\
\text { sen }\end{array}$} \\
\hline & & & $\%$ & & $\%$ & & $\%$ & & $\%$ & & \\
\hline $1919 / 1920$ & Fiú & 78 & 23,7 & 69 & 21,0 & 161 & 48,9 & 19 & 5,8 & 2 & 329 \\
\hline $1927 / 1928$ & Fiú & 204 & 93,6 & - & - & 9 & 4,1 & - & - & 5 & 218 \\
\hline $1928 / 1929$ & Fiú & 56 & 84,8 & - & - & 10 & 15,2 & - & - & - & 66 \\
\hline $1935 / 1936$ & Fiú & 871 & 64,0 & 114 & 8,4 & 292 & 21,5 & 54 & 4,0 & 29 & 1360 \\
\hline \multirow{3}{*}{$\begin{array}{l}\text { 1936/1937 } \\
\text { ipari } \\
\text { líceum }\end{array}$} & Fiú & 826 & 69,9 & 82 & 6,9 & 215 & 18,2 & 43 & 3,6 & 16 & 1182 \\
\hline & Lány & 666 & 73,8 & 33 & 3,7 & 99 & 11,0 & 89 & 9,9 & 16 & 903 \\
\hline & Összesen & 1492 & 71,6 & 115 & 5,5 & 314 & 15,1 & 132 & 6,3 & 32 & 2085 \\
\hline
\end{tabular}


88. A felső fokú állami ipariskolák növendékeinek felekezeti megoszlása:

\begin{tabular}{|c|c|c|c|c|c|c|c|c|c|c|}
\hline & \multicolumn{9}{|c|}{ Beiratkozott diákok vallása } \\
\hline & & 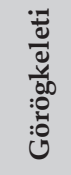 & 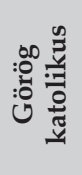 & 节 & 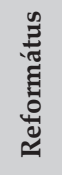 & & 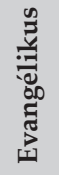 & 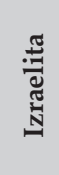 & 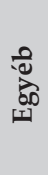 & 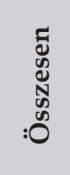 \\
\hline $1927 / 1928$ & Fiú & 204 & 8 & - & 1 & - & - & - & 5 & 218 \\
\hline $1928 / 1929$ & Fiú & 56 & 6 & 4 & - & - & - & - & - & 66 \\
\hline 1930/1931 & Fiú & 287 & 63 & 38 & 9 & 2 & - & 2 & 4 & 405 \\
\hline 1931/1932 & Fiú & 352 & 110 & 78 & 2 & 14 & 4 & 9 & 2 & 571 \\
\hline 1932/1933 & Fiú & 222 & 107 & 114 & 34 & 8 & 9 & 14 & 1 & 509 \\
\hline $1935 / 1936$ & Fiú & 658 & 225 & 272 & 108 & 11 & 29 & 54 & 3 & 1360 \\
\hline \multirow{3}{*}{$\begin{array}{l}\text { 1936/1937 } \\
\text { ipari } \\
\text { líceum }\end{array}$} & Fiú & 615 & 216 & 193 & 7 & 85 & 21 & 43 & 2 & 1182 \\
\hline & Lány & 511 & 152 & 79 & 5 & 44 & 21 & 89 & 2 & 903 \\
\hline & Összesen & 1126 & 368 & 272 & 12 & 129 & 42 & 132 & 4 & 2085 \\
\hline
\end{tabular}

89. A felső fokú állami ipariskolák növendékeinek felekezeti megoszlása, százalékban kifejezve:

\begin{tabular}{|c|c|c|c|c|c|c|c|c|}
\hline & & \multicolumn{7}{|c|}{ Beiratkozott diákok vallása } \\
\hline & & 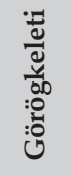 & 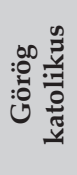 & 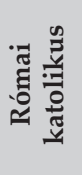 & 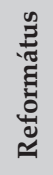 & & 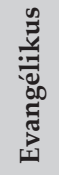 & \\
\hline $1927 / 1928$ & Fiú & 93,6 & 3,7 & - & 0,5 & - & - & - \\
\hline $1928 / 1929$ & Fiú & 84,8 & 9,1 & 6,1 & - & - & - & - \\
\hline 1930/1931 & Fiú & 70,9 & 15,6 & 9,4 & 2,2 & 0,5 & - & 0,5 \\
\hline 1931/1932 & Fiú & 61,6 & 19,3 & 13,7 & 0,4 & 2,5 & 0,7 & 1,6 \\
\hline 1932/1933 & Fiú & 43,6 & 21,0 & 22,4 & 6,7 & 1,6 & 1,8 & 2,8 \\
\hline $1935 / 1936$ & Fiú & 48,4 & 16,5 & 20,0 & 7,9 & 0,8 & 2,1 & 4,0 \\
\hline $1936 / 1937$ & Fiú & 52,0 & 18,3 & 16,3 & 0,6 & 7,2 & 1,8 & 3,6 \\
\hline ipari & Lány & 56,6 & 16,8 & 8,7 & 0,6 & 4,9 & 2,3 & 9,9 \\
\hline líceum & Összesen & 54,0 & 17,6 & 13,0 & 0,6 & 6,2 & 2,0 & 6,3 \\
\hline
\end{tabular}

A lányok szakmai képzését az 1936/1937-es tanévig, amikor is az ipariskolák gimnáziumokká, illetve líceumokká alakultak át, és mind a két nem számára nyíltak osztályok, alsó és felső fokú szakiskolák látták el. Ezekbe az intézményekbe, 1925 után, évente 1000 körüli diák iratkozott be, és hetvenöt-nyolcvankét százalékuk lépett felsőbb osztályba. 
90. Az I. és II. fokú állami leány-szakiskolák diákjai és tanárai:

\begin{tabular}{|c|c|c|c|c|}
\hline & $\begin{array}{c}\text { Intézmények } \\
\text { száma }\end{array}$ & $\begin{array}{c}\text { Beiratkozottak } \\
\text { száma }\end{array}$ & $\begin{array}{c}\text { Felsőbb osztályba } \\
\text { léptek }\end{array}$ & $\begin{array}{c}\text { Tanárok } \\
\text { (mesterek nélkül) }\end{array}$ \\
\hline $\mathbf{1 9 2 1 / 1 9 2 2}$ & 3 & 265 & 217 & 4 \\
\hline $\mathbf{1 9 2 2 / 1 9 2 3}$ & 4 & 181 & 140 & 10 \\
\hline $\mathbf{1 9 2 3 / 1 9 2 4}$ & 12 & 572 & 445 & 50 \\
\hline $\mathbf{1 9 2 4 / 1 9 2 5}$ & 12 & 839 & 648 & 53 \\
\hline $\mathbf{1 9 2 5 / 1 9 2 6}$ & 12 & 1005 & 766 & 42 \\
\hline $\mathbf{1 9 2 6 / 1 9 2 7}$ & 11 & 1152 & 916 & 53 \\
\hline $\mathbf{1 9 2 7 / 1 9 2 8}$ & 13 & 1259 & 964 & 55 \\
\hline $\mathbf{1 9 2 8 / 1 9 2 9}$ & 13 & 1347 & 1055 & 161 (mesterekkel) \\
\hline $\mathbf{1 9 3 0 / 1 9 3 1}$ & 10 & 1076 & 685 & 157 (mesterekkel) \\
\hline $\mathbf{1 9 3 1 / 1 9 3 2}$ & 9 & 990 & 764 & 155 (mesterekkel) \\
\hline $\mathbf{1 9 3 2 / 1 9 3 3}$ & 9 & 958 & 721 & 159 (mesterekkel) \\
\hline $\mathbf{1 9 3 5 / 1 9 3 6}$ & 10 & 1268 & 1007 &
\end{tabular}

Az ipariskolákhoz hasonlóan a leány-szakiskolákban is 1923 után változik meg drasztikusan a diákok nemzetiségi és felekezeti aránya. Ettől az időszaktól kezdve a román etnikumú tanulók több mint hetven, de egyes években akár kilencvenkét százalékot is kitesznek. Ugyanígy a görögkeletiek és görög katolikusok aránya is meghaladja a hetven-nyolcvan százalékot. Ezzel szemben a magyarok és zsidók tíz-húsz százalékot tettek ki együttesen.

91. Az I. és II. fokú állami leány-szakiskolák diákjainak nemzetiségi megoszlása:

\begin{tabular}{|c|c|c|c|c|c|c|c|c|c|c|}
\hline & \multicolumn{10}{|c|}{ Beiratkozott diákok nemzetisége } \\
\hline & \multicolumn{2}{|c|}{ Román } & \multicolumn{2}{|c|}{ Német } & \multicolumn{2}{|c|}{ Magyar } & \multicolumn{2}{|c|}{ Zsidó } & \multirow{2}{*}{ Egyéb } & \multirow{2}{*}{ Összesen } \\
\hline & & $\%$ & & $\%$ & & $\%$ & & $\%$ & & \\
\hline $1921 / 1922$ & 32 & 12,1 & & & & & 39 & 14,7 & 194 & 265 \\
\hline $1922 / 1923$ & 40 & 22,1 & & & & & 26 & 14,4 & 115 & 181 \\
\hline $1923 / 1924$ & 504 & 88,1 & 2 & 0,3 & 32 & 5,6 & 31 & 5,4 & 3 & 572 \\
\hline $1924 / 1925$ & 729 & 86,9 & 11 & 1,3 & 62 & 7,4 & 34 & 4,1 & 3 & 839 \\
\hline $1925 / 1926$ & 916 & 91,1 & - & - & 56 & 5,6 & 28 & 2,8 & 5 & 1005 \\
\hline $1926 / 1927$ & 1053 & 91,4 & 1 & 0,1 & 79 & 6,9 & 18 & 1,6 & 1 & 1152 \\
\hline $1927 / 1928$ & 1157 & 91,9 & 5 & 0,4 & 76 & 6,0 & 13 & 1,0 & 8 & 1259 \\
\hline $1928 / 1929$ & 1219 & 90,5 & 18 & 1,3 & 68 & 5,0 & 30 & 2,2 & 12 & 1347 \\
\hline $1935 / 1936$ & 924 & 72,9 & 40 & 3,2 & 147 & 11,6 & 126 & 9,9 & 31 & 1268 \\
\hline
\end{tabular}


92. Az I. és II. fokú állami leány-szakiskolák diákjainak felekezeti megoszlása:

\begin{tabular}{|c|c|c|c|c|c|c|c|c|c|}
\hline & \multicolumn{9}{|c|}{ Beiratkozott diákok vallása } \\
\hline & 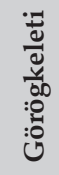 & 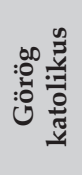 & 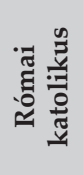 & 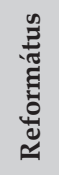 & 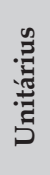 & 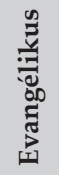 & 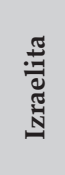 & 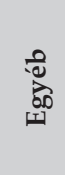 & 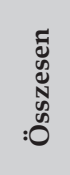 \\
\hline $1921 / 1922$ & 30 & 2 & & & & & 39 & 194 & 265 \\
\hline $1922 / 1923$ & 40 & 2 & & & & & 26 & 113 & 181 \\
\hline $1923 / 1924$ & 275 & 232 & 24 & - & 4 & 6 & 31 & - & 572 \\
\hline $1924 / 1925$ & 426 & 302 & 40 & - & 17 & 20 & 34 & - & 839 \\
\hline $1925 / 1926$ & 515 & 376 & 42 & 3 & 19 & 20 & 28 & 2 & 1005 \\
\hline $1926 / 1927$ & 686 & 363 & 46 & 6 & 23 & 10 & 18 & - & 1152 \\
\hline $1927 / 1928$ & 765 & 383 & 54 & 2 & 28 & 12 & 13 & 2 & 1259 \\
\hline $1928 / 1929$ & 844 & 372 & 58 & 30 & 2 & 10 & 30 & 1 & 1347 \\
\hline $1930 / 1931$ & 655 & 255 & 74 & 1 & 37 & 7 & 41 & 6 & 1076 \\
\hline $1931 / 1932$ & 581 & 216 & 73 & 28 & - & 6 & 84 & 2 & 990 \\
\hline $1932 / 1933$ & 568 & 181 & 78 & 1 & 27 & 23 & 77 & 3 & 958 \\
\hline $1935 / 1936$ & 699 & 211 & 116 & 66 & 7 & 36 & 126 & 7 & 1268 \\
\hline
\end{tabular}

93. Az I. és II. fokú állami leány-szakiskolák diákjainak felekezeti megoszlása, százalékban kifejezve:

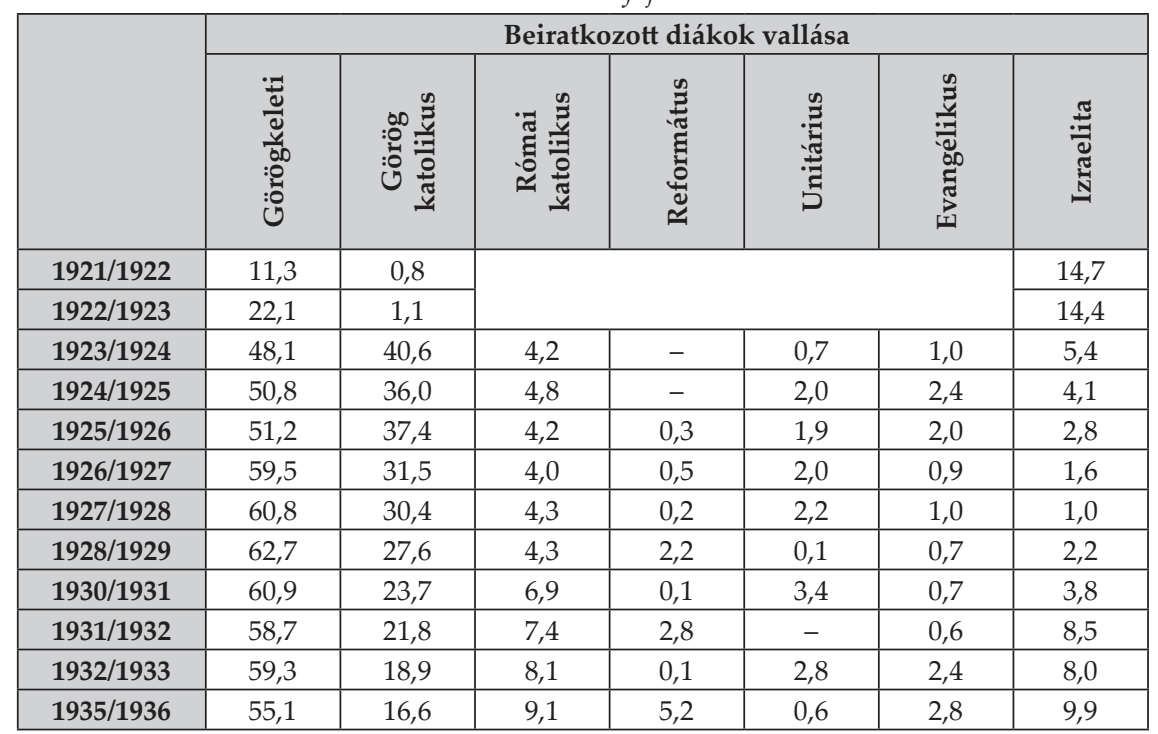


Az 1919/1920-as tanévre nézve alsó fokú mezőgazdasági iskolákról is rendelkezünk adatokkal. Ebben az évben összesen 10 ilyen oktatási intézmény müködött, amelyből hét volt állami és három magán. A szászok által múködtetett magániskolák tanulói szinte kizárólag a német kisebbség közül kerültek ki. Az állami intézményekben elsősorban románok és magyarok tanultak.

94. Az alsó fokú mezógazdasági iskolák tanárainak és diákjainak nemzetiségi megoszlása 1919/1920-ban:

\begin{tabular}{|l|c|c|c|c|c|c|c|}
\hline & \multirow{2}{*}{$\begin{array}{c}\text { Iskolák } \\
\text { száma }\end{array}$} & \multirow{2}{*}{ Tanerők } & \multicolumn{5}{|c|}{ Beiratkozott tanulók } \\
\cline { 4 - 8 } & & & Román & Magyar & Német & Egyéb & Összesen \\
\hline Magán (szász) & 3 & 8 & 2 & 1 & 100 & - & 103 \\
\hline Állami & 7 & 14 & 33 & 27 & 3 & 1 & 64 \\
\hline Összesen & 10 & 22 & 35 & 28 & 103 & 1 & 167 \\
\hline
\end{tabular}

Fiatal lányok háztartási képzését szolgálták az elemi szintű háztartási iskolák. A diákok túlnyomó többsége román etnikumú, illetve görögkeleti és görög katolikus vallású volt.

95. Az állami háztartási leányiskolák diákjai és tanárai:

\begin{tabular}{|c|c|c|c|c|c|c|}
\hline & \multirow[b]{2}{*}{ 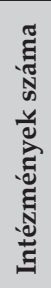 } & \multicolumn{2}{|c|}{ Háztartási oktatás } & \multicolumn{2}{|c|}{ Gazdálkodói oktatás } & \multirow[b]{2}{*}{ 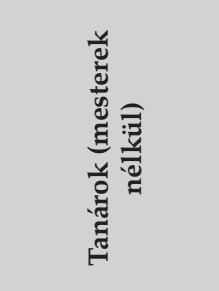 } \\
\hline & & 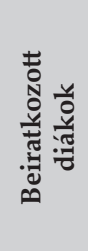 & 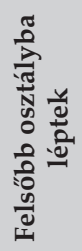 & 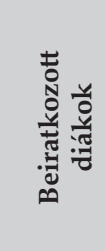 & 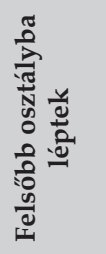 & \\
\hline $1925 / 1926$ & 2 & 98 & 84 & 11 & 10 & 12 \\
\hline $1926 / 1927$ & 4 & 149 & 117 & 25 & 23 & 24 \\
\hline $1927 / 1928$ & 5 & 233 & 167 & 27 & 26 & 41 \\
\hline $1928 / 1929$ & 5 & 261 & 193 & 30 & 28 & 30 \\
\hline 1930/1931 & 4 & 221 & 160 & & & 56 (mesterekkel) \\
\hline 1931/1932 & 4 & 183 & 147 & & & 45 (mesterekkel) \\
\hline $1932 / 1933$ & 8 & 339 & 244 & & & 79 (mesterekkel) \\
\hline $1935 / 1936$ & 8 & 569 & 480 & & & 106 (mesterekkel) \\
\hline
\end{tabular}

96. Az állami háztartási leányiskolák diákjainak nemzetiségi megoszlása:

\begin{tabular}{|c|c|c|c|c|c|c|c|c|c|c|c|}
\hline & \multicolumn{11}{|c|}{ Beiratkozott diákok nemzetisége } \\
\hline & \multicolumn{2}{|c|}{ Román } & \multicolumn{2}{|c|}{ Német } & \multicolumn{2}{|c|}{ Magyar } & \multicolumn{2}{|c|}{ Zsidó } & \multicolumn{2}{|c|}{ Egyéb } & \multirow{2}{*}{ Összesen } \\
\hline & & $\%$ & & $\%$ & & $\%$ & & $\%$ & & $\%$ & \\
\hline $1925 / 1926$ & 116 & 81,1 & 6 & 4,2 & 12 & 8,4 & 3 & 2,1 & 6 & 4,2 & 143 \\
\hline $1926 / 1927$ & 189 & 89,6 & 6 & 2,8 & 7 & 3,3 & 3 & 1,4 & 6 & 2,8 & 211 \\
\hline
\end{tabular}




\begin{tabular}{|l|c|c|c|c|c|c|c|c|c|c|c|}
\hline $\mathbf{1 9 2 7 / 1 9 2 8}$ & 266 & 92,7 & 6 & 2,1 & 4 & 1,4 & 3 & 1 & 8 & 2,8 & 287 \\
\hline $\mathbf{1 9 2 8 / 1 9 2 9}$ & 275 & 92,0 & 6 & 2,0 & 3 & 1,0 & 1 & 0,3 & 14 & 4,7 & 299 \\
\hline $\mathbf{1 9 3 5 / 1 9 3 6}$ & 517 & 90,9 & 20 & 3,5 & 17 & 3 & 7 & 1,2 & 8 & 1,4 & 569 \\
\hline
\end{tabular}

97. Az állami háztartási leányiskolák diákjainak felekezeti megoszlása:

\begin{tabular}{|c|c|c|c|c|c|c|c|c|c|c|c|c|c|}
\hline \multirow{3}{*}{$\begin{array}{c}\text { Háztartási } \\
\text { állami } \\
\text { leányiskolák }\end{array}$} & \multicolumn{13}{|c|}{ Beiratkozott diákok vallása } \\
\hline & \multicolumn{2}{|c|}{ 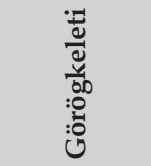 } & \multicolumn{2}{|c|}{ 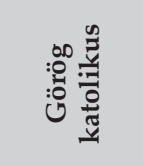 } & \multicolumn{2}{|c|}{ שี } & \multicolumn{2}{|c|}{ 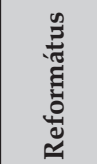 } & \multirow[t]{2}{*}{ 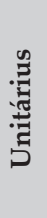 } & \multirow[t]{2}{*}{ 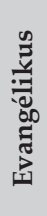 } & \multicolumn{2}{|c|}{ 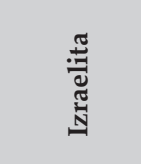 } & \multirow[t]{2}{*}{ 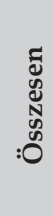 } \\
\hline & & $\%$ & & $\%$ & & $\%$ & & $\%$ & & & & $\%$ & \\
\hline $1925 / 1926$ & 120 & 83,9 & - & - & 19 & 13,3 & 1 & 0,7 & - & - & 3 & 2,1 & 143 \\
\hline 1926/1927 & 165 & 78,2 & 30 & 14,2 & 12 & 5,7 & 1 & 0,5 & - & - & 3 & 1,4 & 211 \\
\hline $1927 / 1928$ & 237 & 82,6 & 37 & 12,9 & 9 & 3,1 & - & - & - & 1 & 3 & 1,0 & 287 \\
\hline 1928/1929 & 234 & 78,3 & 58 & 19,4 & 5 & 1,7 & - & - & - & 1 & 1 & 0,3 & 299 \\
\hline 1930/1931 & 193 & 87,3 & 21 & 9,5 & 3 & 1,4 & - & - & - & - & 4 & 1,8 & 221 \\
\hline 1931/1932 & 159 & 86,9 & 19 & 10,4 & 1 & 0,5 & - & - & - & - & 4 & 2,2 & 183 \\
\hline $1932 / 1933$ & 228 & 67,3 & 88 & 26,0 & 9 & 2,7 & 3 & 0,9 & - & 1 & 10 & 2,9 & 339 \\
\hline $1935 / 1936$ & 330 & 58,0 & 190 & 33,4 & 24 & 4,2 & 11 & 1,9 & 1 & 6 & 7 & 1,2 & 569 \\
\hline
\end{tabular}





\section{AZ ERDÉLYI TANINTÉZMÉNYEK 1940-1948 KÖZÖTT}

Oktatásstatisztikai szempontból Észak- és Dél-Erdélyre nézve az 1940-et követő időszakról rendelkezünk a legkevesebb forrással. Mivel alig készültek kimutatások az oktatási intézmények és a bennük tanuló diákok pontos számát illetően, igen nehézkes ezek dinamikáját ismertetni. Az alábbiakban külön alfejezetekben tárgyaljuk az 1940-1944 és 1944-1948 közötti időszakokat. Az első szakaszban Erdély két részre szakítva, két különböző államhoz tartozott, amelynek következtében még nehezebb pontos képet alkotni az oktatásügyről. Itt elsősorban magyar forrásokra támaszkodhattunk, és ennek okáért főként az észak-erdélyi viszonyok ismertetésére vállalkozhatunk nagyobb bátorsággal. A második világháború alatt Romániához tartozó Dél-Erdélyre nézve még kevesebb információval rendelkezünk.

Az 1944-1948-as periódus az erdélyi oktatásügyben, mint ahogy a romániaiban is, csak kisebb strukturális változásokat eredményezett. Az igazi változást az 1948-as román oktatási törvény jelentette, amely azon túl, hogy államosította az oktatási intézményeket, magát a nevelést is a kommunista szellemiség szolgálatába állította.

\subsection{Az 1940-1944-es időszak}

\subsection{1. Óvodák}

Észak-Erdélyben az 1940/1941-es tanévben 503 óvoda müködött, a következő évben már 559. Többségük állami fenntartású $(82,9 \%)$ vagy községi (10,5\%) tulajdonú volt. Az egyházak közül a római katolikusok és a reformátusok müködtették a legtöbb óvodát, de ezek aránya is alig néhány százalékot tett ki az összes intézmények között. Az ilyen típusú 
intézménymegoszlás lényegében a két világháború közötti folyamatokat tükrözi, amikor is az egyházi és magán oktatási intézmények fokozatosan teret veszítettek az államiakkal szemben. Látható viszont, hogy a második bécsi döntést követően Magyarországhoz került erdélyi területeken újból emelkedni kezdett a nem állami óvodák aránya (Magyar statisztikai évkönyv 1943: 190-193. és 1944: 206-208). ${ }^{15}$

98. Az észak-erdélyi óvodák megoszlása múködtetók szerint:

\begin{tabular}{|c|c|c|c|c|c|c|c|c|c|}
\hline & \multicolumn{2}{|c|}{ Állami } & \multicolumn{2}{|c|}{ Községi } & \multicolumn{2}{c|}{ Egyházi } & \multicolumn{2}{c|}{$\begin{array}{c}\text { Társulati, alapítványi, } \\
\text { magán-, idegen }\end{array}$} & \multirow{2}{*}{ Összesen } \\
\cline { 2 - 9 } & & $\%$ & & $\%$ & & $\%$ & & $\%$ & \\
\hline $\mathbf{1 9 4 0 / 1 9 4 1}$ & 417 & 82,9 & 53 & 10,5 & 30 & 6 & 3 & 0,6 & 503 \\
\hline $\mathbf{1 9 4 1 / 1 9 4 2}$ & 448 & 80,1 & 68 & 12,2 & 36 & 6,4 & 7 & 1,3 & 559 \\
\hline
\end{tabular}

Mivel nem rendelkezünk dél-erdélyi statisztikákkal, az oktatási intézményháló fejlődésének dinamikáját nem tudjuk megbecsülni. Így nem tudjuk, hogy 1940-ben a 470 észak-erdélyi állami és községi óvoda visszalépést vagy előrelépést jelentett az 1936-ban teljes Erdély-szinten működő 807 államihoz képest. Ugyanígy az egyházak által múködtetett intézmények fejlődési ívét sem tudjuk megrajzolni.

Az egyházak és magánosok által fenntartott 30-36 óvoda az összes ilyen jellegű intézmény $6-6,4 \%$-át tette ki, és a következő módon oszlott meg a felekezetek között (Magyar statisztikai évkönyv 1943: 190-193. és 1944: 206-208):

99. Az észak-erdélyi egyházi óvodák megoszlása:

\begin{tabular}{|c|c|c|c|c|c|c|c|c|c|c|c|}
\hline & \multicolumn{2}{|c|}{$\begin{array}{c}\text { Római } \\
\text { katolikus }\end{array}$} & \multicolumn{2}{c|}{$\begin{array}{c}\text { Görög } \\
\text { katolikus }\end{array}$} & \multicolumn{2}{c|}{ Református } & \multicolumn{2}{|c|}{ Evangélikus } & \multicolumn{2}{|c|}{ Izraelita } & \multirow{2}{*}{ Összesen } \\
\cline { 2 - 11 } & & $\%$ & & $\%$ & & $\%$ & & $\%$ & & $\%$ & \\
\hline $\mathbf{1 9 4 0 / 1 9 4 1}$ & 17 & 56,7 & 1 & 3,3 & 6 & 20,0 & 4 & 13,3 & 2 & 6,7 & 30 \\
\hline $\mathbf{1 9 4 1 / 1 9 4 2}$ & 22 & 61,1 & 1 & 2,8 & 7 & 19,4 & 4 & 11,1 & 2 & 5,6 & 36 \\
\hline
\end{tabular}

A növendékek számát illetően ugyancsak az 1940-1941 közötti időszakból rendelkezünk adatokkal. Látható, hogy akár az intézmények esetében, az óvodások számának tekintetében is növekedés tapasztalható (Magyar statisztikai évkönyv 1943: 190-193. és 1944: 206-208).

\footnotetext{
${ }^{15}$ A kimutatás nem tartalmazza a második bécsi döntés során Arad megyétől Magyarországhoz került néhány kisebb település adatait.
} 
100. Az észak-erdélyi óvodák növendékei és tanerói:

\begin{tabular}{|c|c|c|c|}
\hline & Összesen & Tanerők & $\begin{array}{c}\text { Az iskolai év végén } \\
\text { gondozott gyermekek }\end{array}$ \\
\hline $\mathbf{1 9 4 0 / 1 9 4 1}$ & 503 & 1009 & 36578 \\
\hline $\mathbf{1 9 4 1 / 1 9 4 2}$ & 559 & 1155 & 40215 \\
\hline
\end{tabular}

\subsubsection{Elemi oktatás}

A második bécsi döntés következtében Magyarországhoz visszakerült Észak-Erdély oktatásszervezését a magyar adminisztráció át kívánta alakítani. Ez nemcsak az intézménytípusokat, hanem az állami oktatás nyelvét is érintette. Az alábbi, Szlucska János kimutatásainak felhasználásával készült táblázat ezt az átalakulási folyamatot érzékelteti (Szlucska 2009: 515). Látható, hogy az utolsó, 1939/1940-es román tanévben az észak-erdélyi népiskolák túlnyomó többsége román nyelvű volt. A bécsi döntést követően viszont, mint ahogy 22 évvel korábban a román hatóságok románosítani kezdték az iskolákat, a magyar állam megváltoztatta a legtöbb oktatási intézmény tanítási nyelvét magyarra vagy vegyesre.

101. Az észak-erdélyi népiskolák tanitási nyelve:

\begin{tabular}{|c|c|c|c|c|c|c|c|c|c|c|c|}
\hline & \multicolumn{10}{|c|}{ Tanítási nyelv } & \multirow{3}{*}{$\begin{array}{c}\text { Össze- } \\
\text { sen }\end{array}$} \\
\hline & \multicolumn{2}{|c|}{ 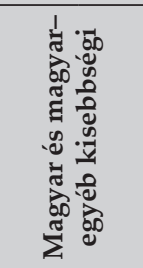 } & \multicolumn{2}{|c|}{ 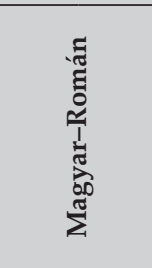 } & \multicolumn{2}{|c|}{ 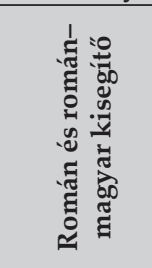 } & \multicolumn{2}{|c|}{ 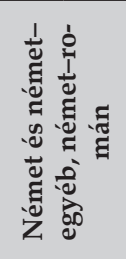 } & \multicolumn{2}{|c|}{ 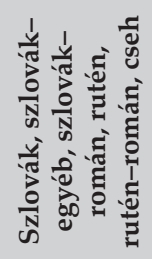 } & \\
\hline & & $\%$ & & $\%$ & & $\%$ & & $\%$ & & $\%$ & \\
\hline $1939 / 1940$ & 167 & 6,7 & 424 & 16,9 & 1829 & 72,9 & 73 & 2,9 & 17 & 0,7 & 2510 \\
\hline $1942 / 1943$ & 1347 & 53,7 & 365 & 14,6 & 729 & 29,1 & 59 & 2,4 & 8 & 0,3 & 2508 \\
\hline
\end{tabular}

A Magyar statisztikai évkönyv adatai némileg eltérnek a Szlucska János által közöltektől. Amíg Szlucska kizárólag csak a népiskolákat veszi számba, addig a Statisztikai évkönyv az elemi szintű oktatás többi típusával is foglalkozik. Eszerint az 1940/1941-es tanévben Észak-Erdélyben 2682 elemi mindennapi iskola, 239 továbbképző (ismétlő)-, 4 önálló (szaktanítós, gazdasági), 42 iparostanonc- és 2 kereskedőtanonc-iskola volt (Magyar statisztikai évkönyv 1943: 190 és 1944: 206). ${ }^{16}$ A következő évben az elemi

\footnotetext{
${ }^{16}$ A kimutatás nem tartalmazza a második bécsi döntés során Arad megyétől Magyarországhoz került néhány kisebb település adatait.
} 
mindennapi és az iparostanonc-iskolák száma nőtt, míg a többieké csökkent.

102. Az észak-erdélyi elemi szintü oktatás iskolatípusai:

\begin{tabular}{|c|c|c|c|c|c|}
\hline \multirow{2}{*}{} & \multicolumn{5}{|c|}{ Népoktatás } \\
\cline { 2 - 6 } & $\begin{array}{c}\text { Elemi } \\
\text { mindennapi }\end{array}$ & $\begin{array}{c}\text { Továbbkép- } \\
\text { ző (ismétlö-) }\end{array}$ & $\begin{array}{c}\text { Önálló (szaktaní- } \\
\text { tós) gazdasági }\end{array}$ & $\begin{array}{c}\text { Iparosta- } \\
\text { nonc }\end{array}$ & $\begin{array}{c}\text { Kereskedő- } \\
\text { tanonc }\end{array}$ \\
\cline { 2 - 6 } iskolák \\
\hline $\mathbf{1 9 4 0 / 1 9 4 1}$ & 2682 & 239 & 4 & 42 & 2 \\
\hline $\mathbf{1 9 4 1 / 1 9 4 2}$ & 2768 & 217 & 4 & 50 & 4 \\
\hline
\end{tabular}

Az elemi mindennapi és a továbbképző iskolák többségét az állam (62\%), valamint a római katolikus és református egyház múködtette. Ennek a két iskolatípusnak a fenntartóira nézve pontos adatokkal rendelkezünk (Magyar statisztikai évkönyv 1943: 193-194. és 1944: 209-210):

103. Az észak-erdélyi elemi mindennapi és továbbképző népiskolák megoszlása a müködtetök szerint:

\begin{tabular}{|l|c|c|c|c|c|c|}
\hline & Állami & Községi & Egyházi & $\begin{array}{c}\text { Társulati, alapít- } \\
\text { ványi, magán-, } \\
\text { idegen, érdekeltségi }\end{array}$ & $\begin{array}{c}\text { Továbbképző } \\
\text { (ismétlö-) } \\
\text { iskolák }\end{array}$ & Összesen \\
\hline $\mathbf{1 9 4 0 / 1 9 4 1}$ & 1812 & 14 & 849 & 7 & 239 & 2921 \\
\hline $\mathbf{1 9 4 1 / 1 9 4 2}$ & 1897 & 15 & 844 & 12 & 217 & 2985 \\
\hline
\end{tabular}

104. Az észak-erdélyi elemi mindennapi és továbbképző népiskolák megoszlása a működtetők szerint, százalékos megoszlásban:

\begin{tabular}{|c|c|c|c|c|c|}
\hline & Állami & Községi & Egyházi & $\begin{array}{c}\text { Társulati, alapítványi, } \\
\text { magán-, idegen, érde- } \\
\text { keltségi }\end{array}$ & $\begin{array}{c}\text { Továbbképző } \\
\text { (ismétlö-) iskolák }\end{array}$ \\
\hline $\mathbf{1 9 4 0 / 1 9 4 1}$ & 62,0 & 0,5 & 29,1 & 0,2 & 8,2 \\
\hline $\mathbf{1 9 4 1 / 1 9 4 2}$ & 63,6 & 0,5 & 28,3 & 0,4 & 7,3 \\
\hline
\end{tabular}

A közel 850 egyházi elemi mindennapi iskola a következőképpen oszlott meg (Magyar statisztikai évkönyv 1943: 193-194. és 1944: 209-210):

105. Az észak-erdélyi egyházi elemi mindennapi népiskolák megoszlása az egyházak között:

\begin{tabular}{|c|c|c|c|c|c|c|c|c|}
\hline & 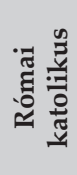 & 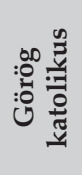 & 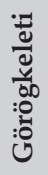 & 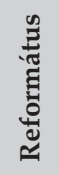 & 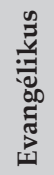 & & & 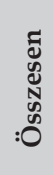 \\
\hline $1940 / 1941$ & 242 & 31 & 2 & 482 & 50 & 23 & 19 & 849 \\
\hline $1941 / 1942$ & 244 & 29 & 2 & 477 & 50 & 23 & 19 & 844 \\
\hline
\end{tabular}


106. Az észak-erdélyi egyházi elemi mindennapi népiskolák megoszlása az egyházak között, százalékban kifejezve:

\begin{tabular}{|c|c|c|c|c|c|c|c|}
\hline & 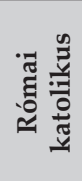 & 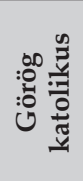 & 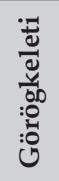 & 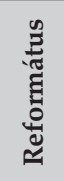 & 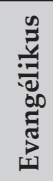 & & 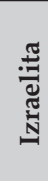 \\
\hline $1940 / 1941$ & 28,5 & 3,7 & 0,2 & 56,8 & 5,9 & 2,7 & 2,2 \\
\hline 1941/1942 & 28,9 & 3,4 & 0,2 & 56,5 & 5,9 & 2,7 & 2,3 \\
\hline
\end{tabular}

Az iparos- és kereskedőtanonc-iskolákat, néhány kivétellel, a községek tartották fenn. Az állam és az egyházak is csak 3-3 iparostanonc-iskolát müködtettek (Magyar statisztikai évkönyv 1943: 198-199. és 1944: 214-215).

107. Az észak-erdélyi iparos-és kereskedőtanonc-iskolák megoszlása müködtetők szerint:

\begin{tabular}{|c|c|c|c|c|c|}
\hline & \multicolumn{3}{|c|}{ Iparostanonc iskolák } & $\begin{array}{c}\text { Kereskedőtanonc } \\
\text { iskolák }\end{array}$ & \multirow{2}{*}{ Összesen } \\
\cline { 2 - 5 } & Állami & Községi & $\begin{array}{c}\text { Egyházi (római } \\
\text { katolikus és refor- } \\
\text { mátus) }\end{array}$ & Községi & \\
\hline $1940 / 1941$ & 3 & 36 & 3 & 2 & 44 \\
\hline $1941 / 1942$ & 3 & 44 & 3 & 4 & 54 \\
\hline
\end{tabular}

1940 után tehát tovább folytatódott az egyházak által fenntartott elemi iskolák számának csökkenése, viszont ezek között továbbra is domináns maradt a római katolikus és a református egyházak kötelékébe tartozó intézmények száma. Említettük már, hogy 1918 után a román állam románosította az állami oktatási intézményeket, és ugyanígy járt el a magyar állam is 1940-et követően az észak-erdélyi iskolákkal, amikor azok többségébe újból magyar tanítási nyelvet vezetett be. Az 1940-es második bécsi döntés másik lényeges kísérőjelensége a román tanítók és tanárok nagyarányú távozása Észak-Erdélyből. 1940 augusztusában 4700 román nemzetiségü tanító tevékenykedett Észak-Erdélyben, de az elkövetkező időszakban 84,7 százalékuk román területre távozott. Ugyanígy a román nemzetiségü tanárok nagy része is elmenekült/eltávozott (Sebestyén 1998: 167).

A tanulók és tanerők számát illetően ugyancsak a Magyar statisztikai évkönyv adatait használjuk fel. Az elemi mindennapi népiskolákban 1940/1941-ben 6862 pedagógus müködött, és a következő tanévre a számuk több mint ötszázzal nőtt. Ők több mint 370 000, illetve 398000 tanulónak az oktatásáról gondoskodtak (Magyar statisztikai évkönyv 1943: 193-194. és 1944: 209-210). 
108. Az észak-erdélyi elemi mindennapi népiskolák tanulói és tanárai:

\begin{tabular}{|l|c|c|c|c|}
\hline & Tanerők & $\begin{array}{c}\text { A mindennapi } \\
\text { elemi iskolák ta- } \\
\text { nulóinak száma }\end{array}$ & $\begin{array}{c}\text { A továbbképző (is- } \\
\text { métlő-) elemi iskolák } \\
\text { tanulóinak száma }\end{array}$ & Összes tanuló \\
\hline $\mathbf{1 9 4 0 / 1 9 4 1}$ & 6862 & 357188 & 13630 & 370818 \\
\hline $\mathbf{1 9 4 1 / 1 9 4 2}$ & 7380 & 387384 & 11460 & 398844 \\
\hline
\end{tabular}

A szakképzést biztosító iparos- és kereskedőtanonc-iskolákban a két vizsgált tanévben 318 és 375 pedagógus dolgozott, míg a diákok száma meghaladta a 7300-7790-et (Magyar statisztikai évkönyv 1943: 198-199. és 1944: 214-215):

109. Az észak-erdélyi iparos-és kereskedőtanonc-iskolák diákjai és tanárai:

\begin{tabular}{|c|c|c|c|c|c|c|c|c|}
\hline & \multicolumn{4}{|c|}{ Iparostanonc-iskolák } & \multicolumn{4}{|c|}{ Kereskedőtanonc-iskolák } \\
\hline & \multirow[b]{2}{*}{ 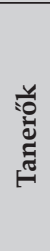 } & \multicolumn{3}{|c|}{ Tanulók } & \multirow[b]{2}{*}{ 范 } & \multicolumn{3}{|c|}{ Tanulók } \\
\hline & & 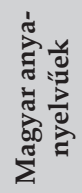 & 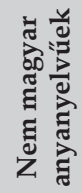 & 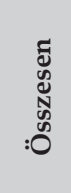 & & 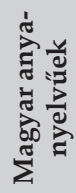 & 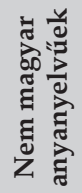 & 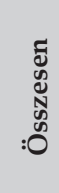 \\
\hline $1940 / 1941$ & 308 & 5959 & 1224 & 7183 & 10 & 115 & 11 & 126 \\
\hline 1941/1942 & 354 & 6495 & 1083 & 7578 & 21 & 202 & 17 & 219 \\
\hline
\end{tabular}

Az elemi szintű oktatásról elmondható tehát, hogy 1940/1941-ben öszszesen 2969 népoktatási intézmény működött Észak-Erdélyben. A népoktatási intézményekben 7180 tanerő dolgozott és 378127 diák tanult. 1941/1942-ben a népoktatási intézmények száma 3043 volt. Ebben az évben a tanszemélyzet száma 7755-re, a diákoké pedig 406 641-re emelkedett.

\subsubsection{Középfokú oktatás}

A Magyar statisztikai évkönyv a középfokú oktatás legalsó szintjét képező polgári iskolák esetében és a tanítóképzőkre nézve is csak az intézmények számáról közöl adatokat. Eszerint 1940/1941-ben 52 polgári iskola és 14 óvó- és tanítóképző intézet működött Észak-Erdélyben. A következő tanévben a polgári iskolák száma 50-re csökkent, a tanítóképzőké pedig 11-re (Magyar statisztikai évkönyv 1943: 190-191. és 1944: 206-207).

A polgári iskolák esetében a csökkenés tovább folytatódott 1942/1943-ban is. Ekkor a 48 iskolából 44-ben magyarul folyt a tanítás, 3-ban németül és 1-ben románul. Amennyiben összehasonlítjuk a román uralom alatti utolsó évvel az adatainkat, akkor azt látjuk, hogy a polgári is- 
kolák tanítási nyelve lényegesen megváltozott. Amíg a második bécsi döntés elött a polgári iskolák szerepét ellátó algimnáziumok 54,3\%-ában volt román nyelvú oktatás, addig 1942/1943-ban már csak 2,1\%-ban (Szlucska 2009: 523-525).

110. Az észak-erdélyi polgári iskolák megoszlása tanitási nyelv szerint 1939/1940-ben és 1942/1943-ban:

\begin{tabular}{|l|c|c|c|c|c|c|c|c|c|}
\hline & \multicolumn{7}{|c|}{ Tanítási nyelv } & \multicolumn{2}{c|}{ Összesen } \\
\cline { 2 - 10 } & \multicolumn{2}{|c|}{ Román } & \multicolumn{2}{c|}{ Magyar } & \multicolumn{2}{c|}{ Német } & \multicolumn{2}{c|}{ Francia } & \% \\
\cline { 2 - 10 } & & $\%$ & & $\%$ & & $\%$ & & $\%$ \\
\hline $\begin{array}{l}\text { 1939/1940 } \\
\text { algimnáziumok }\end{array}$ & 19 & 54,3 & 12 & 34,2 & 3 & 8,6 & 1 & 2,9 & 35 \\
\hline $\begin{array}{l}\text { 1942/1943 } \\
\text { polgári iskolák }\end{array}$ & 1 & 2,1 & 44 & 91,6 & 3 & 6,3 & - & - & 48 \\
\hline
\end{tabular}

A diákok etnikai megoszlását illetően is jelentős változás következett be 1940 után. Ahogy a tanítási nyelv esetében is láttuk, a két világháború közötti időszakhoz képest a második bécsi döntést követően 36,4\%-ról 4,9\%-ra esett vissza a román diákok aránya és 49,2\%-ról 91,2\%-ra nőtt a magyaroké (Szlucska 2009: 540-541).

111. Az észak-erdélyi algimnáziumok és polgári iskolák diákjainak nemzetiségi megoszlása:

\begin{tabular}{|c|c|c|c|c|c|c|c|c|c|c|c|}
\hline & & \multicolumn{10}{|c|}{ A diákok nemzetisége } \\
\hline & & \multicolumn{2}{|c|}{ Román } & \multicolumn{2}{|c|}{ Magyar } & \multicolumn{2}{|c|}{ Német } & \multicolumn{2}{|c|}{ Egyéb } & \multicolumn{2}{|c|}{ Összesen } \\
\hline & & & $\%$ & & $\%$ & & $\%$ & & $\%$ & & $\%$ \\
\hline \multirow{3}{*}{$\begin{array}{l}\text { 1939/1940 } \\
\text { algimnázi- } \\
\text { umok }\end{array}$} & $\begin{array}{l}\text { anyanyel- } \\
\text { vén tanult }\end{array}$ & 1609 & 97,0 & 1408 & 63,0 & 321 & 92,6 & - & - & 3338 & 73,3 \\
\hline & $\begin{array}{l}\text { nem } \\
\text { anyanyel- } \\
\text { vén tanult }\end{array}$ & 48 & 3,0 & 827 & 37,0 & 26 & 7,4 & 311 & 100,0 & 1212 & 26,7 \\
\hline & összesen & 1657 & 36,4 & 2235 & 49,2 & 347 & 7,6 & 311 & 6,8 & 4550 & 100 \\
\hline \multirow{3}{*}{$\begin{array}{l}\text { 1942/1943 } \\
\text { polgári } \\
\text { iskolák }\end{array}$} & $\begin{array}{l}\text { anyanyel- } \\
\text { vén tanult }\end{array}$ & 135 & 21,9 & 11321 & 100,0 & 410 & 97,4 & - & - & 11866 & 95,5 \\
\hline & $\begin{array}{l}\text { nem } \\
\text { anyanyel- } \\
\text { vén tanult }\end{array}$ & 480 & 78,1 & - & - & 11 & 2,6 & 74 & 100,0 & 565 & 4,5 \\
\hline & összesen & 615 & 4,9 & 11321 & 91,2 & 421 & 3,4 & 74 & 0,5 & 12431 & 100,0 \\
\hline
\end{tabular}

A Magyar Királyi Vallás- és Közoktatásügyi Minisztérium V.1-es ügyosztálya 1940. augusztus 10-én, tehát a területi változásokat megelőzően néhány héttel tervezetet készített az észak-erdélyi iskolahálózat megszervezéséről. ${ }^{17} \mathrm{~A}$ tervezet többek között az engedélyezendő fiú- és leány${ }^{17}$ MOL K592, 689. csomó, 4. tétel, Erdélyi gimnáziumok nyilvántartása, 193-252. 
gimnáziumok, valamint a főgimnáziumok (líceumok) számáról és tanítási nyelvéről rendelkezett. Eszerint 1940-től a korábbi 92 helyett összesen 63 gimnázium és főgimnázium működött volna a visszacsatolt területen (ezek közül 52 fiú-, 11 pedig leányintézmény). Az iskolák közül 53-at magyar, 8-at német és 5-öt román tanítási nyelvüre terveztek. Emellett a magyar tanítási nyelvü állami főgimnáziumokban 4 román nyelvủ tagozat is múködött volna (Déva, Nagyszeben, Fogaras, Kolozsvár). Az alábbiakban ezeknek az intézeteknek a megoszlása szerepel:

112. A Magyar Királyi Vallás- és Közoktatásügyi Minisztérium tervezete az észak-erdélyi gimnáziumok és fógimnáziumok tanitási nyelvéról (1940):

\begin{tabular}{|c|c|c|c|c|c|c|c|c|c|c|c|}
\hline \multirow{3}{*}{$\begin{array}{l}\text { Tanítási } \\
\text { nyelv }\end{array}$} & \multicolumn{11}{|c|}{ Gimnáziumok és főgimnáziumok jellege } \\
\hline & \multicolumn{2}{|c|}{ Állami } & \multirow{2}{*}{ 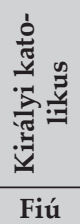 } & \multicolumn{2}{|c|}{$\begin{array}{c}\text { Római } \\
\text { katolikus }\end{array}$} & \multirow{2}{*}{ 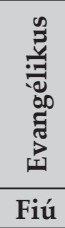 } & \multicolumn{2}{|c|}{ Református } & \multirow{2}{*}{ 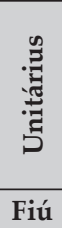 } & \multirow{2}{*}{ 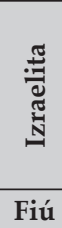 } & \multirow{2}{*}{ 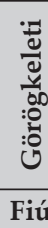 } \\
\hline & Fiú & Leány & & Fiú & Leány & & Fiú & Leány & & & \\
\hline Magyar & 20 & 5 & 3 & 10 & 4 & - & 7 & 1 & 2 & 1 & - \\
\hline Német & 1 & - & - & 1 & 1 & 5 & - & - & - & - & - \\
\hline Román & 4 & - & - & - & - & - & - & - & - & - & 2 \\
\hline
\end{tabular}

A minisztérium szándéka az volt, hogy a román uralom alatt is fennálló és a második bécsi döntés időpontjában működő magyar nyelvű felekezeti gimnáziumokat nem szervezi át. Ugyanígy a német nyelvű felekezeti gimnáziumokat is meg kívánta hagyni. Ezzel szemben a román felekezeti intézmények esetében csak abban az esetben kívánta engedélyezni müködésüket, ha a román adminisztráció alatt, azaz 1918-1940 között nem váltak állami jellegüekké. Az állami főgimnáziumok terén kívánták a legnagyobb változásokat végrehajtani. Ezek ugyanis 1918 után mind román tanítási nyelvűekké váltak. A tervezet szerint csak azokat az állami főgimnáziumokat hagyták volna meg, amelyek múködése iskolapolitikai szempontból indokolt, és nem gyengítik az ugyanazon településen müködő magyar felekezeti iskolákat. A tervezet a román időszak alatt államosított magyar felekezeti iskolák eredeti jellegét szándékozott visszaállítani.

A korabeli statisztikák alapján úgy tünik, hogy a magyar Vallás- és Közoktatásügyi Minisztérium tervezete ténylegesen is megvalósult 1940 őszétől. Az 1940/1941-es tanévben ugyanis összesen 63 gimnázium és líceum működött Észak-Erdély városaiban. Ehhez még hozzáadódott 3 ipari középiskola és 10 kereskedelmi középiskola. 1941/1942-ben viszont 61-re csökkent a gimnáziumok és a líceumok száma. Mindemellett 2 honvéd 
középiskola is nyílt (Magyar statisztikai évkönyv 1943: 190-191. és 1944: 206-207).

113. Az észak-erdélyi középiskolák megoszlása típusonként:

\begin{tabular}{|c|c|c|c|c|c|c|c|c|}
\hline & \multicolumn{8}{|c|}{ Középiskolák } \\
\hline & 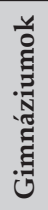 & 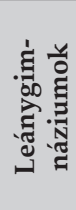 & 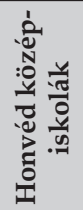 & 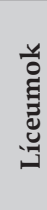 & 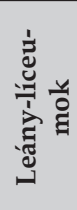 & 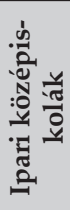 & 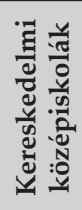 & 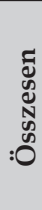 \\
\hline $1940 / 1941$ & 36 & 15 & - & 6 & 6 & 3 & 10 & 76 \\
\hline $1941 / 1942$ & 35 & 11 & 2 & 7 & 8 & 3 & 9 & 75 \\
\hline
\end{tabular}

\subsection{Az 1944-1948 közötti évek}

A második világháborút követő négy év oktatásügyéről még kevesebb statisztikával rendelkezünk. Azok a tanulmányok, amelyek a korszakkal foglalkoznak, csak egy-egy résztémát vagy valamely etnikum - elsősorban a magyarok - speciális ügyét érintik az oktatásügy kapcsán.

Amikor a román adminisztráció visszatért Eszak-Erdélybe, az oktatási intézmények újból gazdát cseréltek. 1945 májusában királyi dekrétum rendelte el, hogy mindazon román tanintézmények, amelyek 1940 után eltávoztak Észak-Erdélyből, visszatérhetnek korábbi épületeikbe. Ez azzal járt, hogy a magyar iskolák jelentős részének költöznie kellett (Vincze 1999: 191).

Részletesebb statisztikákat a román Nemzeti Művelődési és Vallásügyi Minisztérium 1946-os kimutatásai közölnek. Ez lényegében az 1945/1946-os tanévet érinti, és ennek alapján próbáljuk meg rekonstruálni a második világháború utáni erdélyi oktatásügy helyzetét.

Az elemi iskolákat illetôen nem rendelkezünk regionális bontással, így csak az országos adatokat ismerjük. Romániában 1945/1946-ban 12270 állami és 773 egyházi elemi iskola müködött. Rajtuk kívül további 1163 magán elemi iskola és óvoda állt fenn. Az állami iskolák közül 932 volt magyar és 29 ukrán tanítási nyelvư. További 23 intézményben külön ukrán szekció is müködött. ${ }^{18} \mathrm{~A}$ több mint 12 ezer elemi iskolában 46477 pedagógus tanított, amelyek közül 2855 volt magyar nemzetiségü. ${ }^{19}$

\footnotetext{
${ }^{18}$ Arhivele Naționale Istorice Centrale, Bucureşti (a továbbiakban: ANIC), Fond: Ministerul Culturii Naționale şi al Cultelor, inv. 2325, dos. 603, 5.

${ }^{19}$ Uo.
} 
114. Az elemi iskolák száma Romániában az 1945/1946-os tanévben:

\begin{tabular}{|l|c|}
\hline Elemi állami iskolák & 12270 \\
\hline Ukrán tanítási nyelvü iskolák & 29 \\
\hline Ukrán szekciók & 23 \\
\hline Magyar tanítási nyelvủ állami elemik & 932 \\
\hline Egyházi elemik & 773 \\
\hline Magán elemik és óvodák & 1163 \\
\hline
\end{tabular}

Az 1944 előtti időszakhoz és az 1948 utánihoz képest is a középiskolai oktatás területén figyelhető meg a legjelentősebb eltérés. 1945 augusztusában a Groza-kormány 3 éves képzést biztosító, ún. egységes gimnáziumokat (gimnazii unice) hozott létre. Ezek az intézmények az oktatás felzárkóztatását célozták meg. Megfelelő számú pedagógus hiányában, valamint az elmaradott oktatási infrastruktúra (pl. alkalmas iskolaépületek hiánya) következtében csak nagyobb településeken indulhatott be az ilyen típusú oktatási intézmény. Erdélyben az 1945/1946-os tanévben 242 müködött belőlük. Az 1948-as tanügyi reform megszüntette az egységes gimnáziumokat, így ezek mindössze három évig müködhettek (Bunescu 2004: 343).

Az 1945/1946-os tanévben összesen 408 középiskola volt Erdélyben 2859 pedagógussal. Az intézményekből 83 elméleti líceum és gimnázium volt, az ipari és kereskedelmi középfokú képzést pedig 50 tanintézmény látta el. Tanítóképzés 21 iskolában folyt. ${ }^{20}$

115. Az erdélyi középiskolák megoszlása típusuk szerint 1945/1946-ban:

\begin{tabular}{|l|c|c|c|c|}
\hline & $\begin{array}{c}\text { Fiúiskolák } \\
\text { száma }\end{array}$ & $\begin{array}{c}\text { Leányiskolák } \\
\text { száma }\end{array}$ & $\begin{array}{c}\text { Vegyes } \\
\text { iskolák }\end{array}$ & Összesen \\
\hline $\begin{array}{l}\text { Elméleti líceumok } \\
\text { és gimnáziumok }\end{array}$ & 37 & 32 & 14 & 83 \\
\hline $\begin{array}{l}\text { Kereskedelmi líceumok } \\
\text { és gimnáziumok }\end{array}$ & 10 & 5 & 2 & 17 \\
\hline $\begin{array}{l}\text { Ipari líceumok } \\
\text { és gimnáziumok }\end{array}$ & 21 & 12 & - & 33 \\
\hline Tanítóképzők & 11 & 9 & 1 & 21 \\
\hline $\begin{array}{l}\text { Háztartási iskolák } \\
\text { (gospodărie) }\end{array}$ & - & 12 & - & 12 \\
\hline $\begin{array}{l}\text { Egységes gimnáziumok } \\
\text { (Gimnazii unice) }\end{array}$ & - & - & 242 & 242 \\
\hline Összesen & 79 & 70 & 259 & 408 \\
\hline
\end{tabular}

\footnotetext{
${ }^{20}$ Uo. 6-7.
} 
A több mint 56000 erdélyi középiskolai diáknak 53,5\%-a járt elméleti líceumba vagy gimnáziumba (1928/1929-ben 68,7\% volt ez az arány). A falvakon működő egységes gimnáziumok a diákok további 17,6\%-át oktatták. ${ }^{21}$

116. Az erdélyi középiskolákban tanuló diákok száma 1945/1946-ban:

\begin{tabular}{|l|c|c|c|c|}
\hline & Fiúiskolák & Leányiskolák & $\begin{array}{c}\text { Vegyes } \\
\text { iskolák }\end{array}$ & Összesen \\
\hline $\begin{array}{l}\text { Elméleti líceumok } \\
\text { és gimnáziumok }\end{array}$ & 15612 & 12195 & 2430 & 30237 \\
\hline $\begin{array}{l}\text { Kereskedelmi líceumok } \\
\text { és gimnáziumok }\end{array}$ & 2897 & 1615 & 506 & 5018 \\
\hline Ipari líceumok és gimnáziumok & 3355 & 2275 & - & 5630 \\
\hline Tanítóképzők & 2175 & 2183 & 224 & 4582 \\
\hline Háztartási iskolák (gospodărie) & - & 1113 & - & 1113 \\
\hline $\begin{array}{l}\text { Egységes gimnáziumok } \\
\text { (Gimnazii unice) }\end{array}$ & - & - & 9932 & 9932 \\
\hline Összesen & 24039 & 19381 & 13092 & 56512 \\
\hline
\end{tabular}

\footnotetext{
${ }^{21}$ Uo.
} 



\section{FELSŐOKTATÁS}

Az erdélyi felsőoktatás csúcspontját a kolozsvári Ferdinánd Király Tudományegyetem képezte. Mellette viszont további felső fokú képzést biztosító intézmények is működtek: Agrártudományi Akadémia (Kolozsvár), Felsőkereskedelmi és Ipari Akadémia (Kolozsvár), Zenetudományi Akadémia (Kolozsvár), Jogi Akadémia (Nagyvárad), Műszaki Főiskola (Temesvár), Elektromechanikai Almérnöki Iskola (Kolozsvár), Szépművészeti Iskola (Temesvár) és a különböző felekezetekhez tartozó teológiai intézetek.

A felsőoktatási intézmények tanítási nyelvévé a magyar helyett a román vált, és az 1918 előtti állapotokhoz képest jelentősen átalakult a diákok etnikai összetétele. A tanítási nyelv megváltozása, főleg az első években, jelentős visszatartó tényezőt jelentett a románul nem tudó magyar és egyéb kisebbségi fiatalok számára a beiratkozásokkor.

A felsőoktatási intézményekben jellemző módon a görögkeletiek, a görög katolikusok és az izraelita diákok felülreprezentáltságát figyelhetjük meg. Ez az egyes felekezetekre/etnikumokra jellemző modernizációs szint és társadalmi rétegződés mellett a középiskolákból kikerülő diákok megoszlásával is összefüggésben állt. A líceumokban és kereskedelmi iskolákban a románok és zsidók voltak túlsúlyban, így természetes, hogy a müszaki, kereskedelmi, mérnöki, agrártudományi főiskolákra is ők felvételiztek többen.

Mindezek mellett nemcsak Erdélyben, hanem Nagy-Románia többi egyetemein, főiskoláin is megnőtt a hallgatók összlétszáma, amely főként a Romániához csatolt új területek szempontjából bizonyult lényegesnek. A felsőoktatási intézmények tanulói etnikai megoszlásának megváltoztatásával és a diáklétszám növekedésével akarta ugyanis elérni a román állam 
egy új, román elit megteremtését és megerősítését a többnemzetiségű régiókban, így Erdélyben is (Kiss 2010: 19, Livezeanu 1995: 211).

A két világháború közötti román felsőoktatási rendszer egyik nagy hiányossága volt az, hogy a diáklétszám növekedése és a megszerezhető képesítések nem álltak arányban a munkaerő-piaci igényekkel. Ez az aránytalanság a szellemi munkaerőpiac túlnépesedéséhez vezetett, amely komoly konfliktushelyzeteket teremtett. A két világháború között gyakoriak voltak a diáktüntetések, randalírozások, amelyek az egyetemi oktatási rendszer átalakítását, a diákok életkörülményeinek és a tanulási feltételek javítását, valamint a nem román diákok létszámának korlátozását (numerus clausus) követelték. A legtöbb diáktüntetést kifejezetten zsidóellenes megnyilvánulások is kísérték, mint például az 1927. decemberi nagyváradi és kolozsvári diáktüntetéseket (Gidó 2006: 41-43).

\subsection{Elektromechanikai almérnöki iskola, Kolozsvár}

A Kolozsváron működő elektromechanikai almérnöki iskolát 1937-ben hozták létre. Az intézmény viszont egyéb elnevezéssel és oktatási szinttel már 1920-tól múködött. Az első világháborút követően több olyan ipari vállalat is létrejött Erdélyben (Aranyosgyéres, Nagybánya, Brassó, Pusztakala), amelyeknek számára elengedhetetlenül fontos volt, hogy jól képzett szakembereket (mérnököket, müszaki ismeretekkel rendelkező szakmunkásokat) alkalmazhassanak. Ezeket az igényeket igyekeztek kielégíteni a kolozsvári Ipari Felsőiskola (Şcoala Superioară Industrială) 1920-as elindításával, amely 1922 és 1937 között a Müszaki Vezetők Iskolája (Şcoală de Conducători Tehnici) nevet viselte. 1937-ben ezt az intézményt alakították át elektromechanikai almérnöki iskolává (Drăgoescu 1999: 1191).

$\mathrm{Az}$ elektromechanikai iskolába elsősorban fiúnövendékek jártak. 1937-ig a számuk 35 és 84 között volt, az 1938-as tanévtől viszont 120 fölé emelkedett. A diákok nemzetiségi összetétele változó volt az évek során, de 1935-öt és 1936-ot kivéve a románok alkották az abszolút többséget. A magyarok aránya 14-31\% között, a zsidóké pedig 10-21\% között mozgott. A lánynövendékek elsősorban a zsidók közül kerültek ki: 1934/1935-ben három, 1935/1936 és 1937/1938 között pedig két-két, a következő két tanévben pedig egy-egy zsidó lány járt az almérnöki iskolába. 
117. A kolozsvári Elektromechanikai Almérnöki Iskola diákjainak nemzetiségi megoszlása:

\begin{tabular}{|c|c|c|c|c|c|c|c|c|c|c|c|c|c|c|}
\hline & \multirow{3}{*}{ 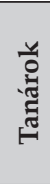 } & \multicolumn{10}{|c|}{ Beiratkozott diákok nemzetisége } & \multicolumn{3}{|c|}{ Összesen } \\
\hline & & \multicolumn{2}{|c|}{ Román } & \multicolumn{2}{|c|}{ Német } & \multicolumn{2}{|c|}{ Magyar } & \multicolumn{2}{|c|}{ Zsidó } & \multicolumn{2}{|c|}{ Egyéb } & \multirow{2}{*}{ 焉 } & \multirow{2}{*}{ 汭 } & \multirow{2}{*}{ 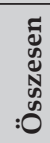 } \\
\hline & & & $\%$ & & $\%$ & & $\%$ & & $\%$ & & $\%$ & & & \\
\hline 1933/1934 & 17 & 24 & 68,6 & 1 & 2,9 & 5 & 14,3 & 4 & 11,4 & 1 & 2,9 & 35 & - & 35 \\
\hline 1934/1935 & 16 & 30 & 57,7 & 2 & 3,8 & 9 & 17,3 & 10 & 19,2 & 1 & 1,9 & 49 & 3 & 52 \\
\hline $1935 / 1936$ & 16 & 28 & 45,2 & 2 & 3,2 & 19 & 30,6 & 13 & 21,0 & - & - & 60 & 2 & 62 \\
\hline $1936 / 1937$ & 23 & 38 & 45,2 & 3 & 3,6 & 26 & 31,0 & 14 & 16,7 & 3 & 3,6 & 82 & 2 & 84 \\
\hline $1937 / 1938$ & 23 & 40 & 54,1 & 1 & 1,4 & 18 & 24,3 & 10 & 13,5 & 5 & 6,8 & 71 & 3 & 74 \\
\hline $1938 / 1939$ & 23 & 82 & 67,2 & 1 & 0,8 & 21 & 17,2 & 12 & 9,8 & 6 & 4,9 & 120 & 2 & 122 \\
\hline $1939 / 1940$ & 23 & 66 & 53,7 & 2 & 1,6 & 27 & 22,0 & 19 & 15,4 & 9 & 7,3 & 120 & 3 & 123 \\
\hline
\end{tabular}

A tanulók, az etnikai arányoknak megfelelően, főként görögkeletiek és görög katolikusak voltak. Őket arányban a római katolikusok, az izraeliták és a reformátusok követték.

118. A kolozsvári Elektromechanikai Almérnöki Iskola diákjainak felekezeti megoszlása:

\begin{tabular}{|c|c|c|c|c|c|c|c|c|}
\hline & \multicolumn{8}{|c|}{ Beiratkozott diákok vallása } \\
\hline & 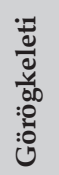 & 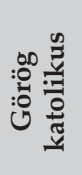 & 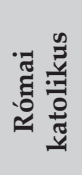 & 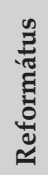 & & 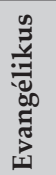 & & 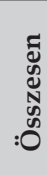 \\
\hline 1933/1934 & 17 & 8 & 4 & 2 & - & - & 4 & 35 \\
\hline $1934 / 1935$ & 25 & 6 & 3 & 5 & 1 & 2 & 10 & 52 \\
\hline $1935 / 1936$ & 18 & 10 & 7 & 8 & 3 & 3 & 13 & 62 \\
\hline $1936 / 1937$ & 28 & 13 & 13 & 9 & 3 & 4 & 14 & 84 \\
\hline $1937 / 1938$ & 28 & 16 & 8 & 8 & 2 & 2 & 10 & 74 \\
\hline 1938/1939 & 56 & 31 & 15 & 4 & - & 4 & 12 & 122 \\
\hline $1939 / 1940$ & 49 & 24 & 16 & 10 & 1 & 4 & 19 & 123 \\
\hline
\end{tabular}

119. A kolozsvári Elektromechanikai Almérnöki Iskola diákjainak felekezeti megoszlása, százalékban kifejezve:

\begin{tabular}{|c|c|c|c|c|c|c|c|}
\hline & \multicolumn{7}{|c|}{ Beiratkozott diákok vallása } \\
\hline & 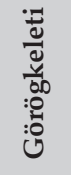 & 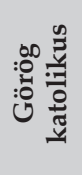 & 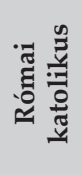 & 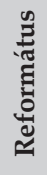 & & 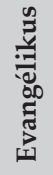 & 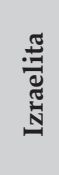 \\
\hline $1933 / 1934$ & 48,6 & 22,9 & 11,4 & 5,7 & - & - & 11,4 \\
\hline $1934 / 1935$ & 48,1 & 11,5 & 5,8 & 9,6 & 1,9 & 3,8 & 19,2 \\
\hline
\end{tabular}




\begin{tabular}{|c|c|c|c|c|c|c|c|}
\hline $\mathbf{1 9 3 5 / 1 9 3 6}$ & 29,0 & 16,1 & 11,3 & 12,9 & 4,8 & 4,8 & 21,0 \\
\hline $\mathbf{1 9 3 6 / 1 9 3 7}$ & 33,3 & 15,5 & 15,5 & 10,7 & 3,6 & 4,8 & 16,7 \\
\hline $\mathbf{1 9 3 7 / 1 9 3 8}$ & 37,8 & 21,6 & 10,8 & 10,8 & 2,7 & 2,7 & 13,5 \\
\hline $\mathbf{1 9 3 8 / 1 9 3 9}$ & 45,9 & 25,4 & 12,3 & 3,3 & - & 3,3 & 9,8 \\
\hline $\mathbf{1 9 3 9 / 1 9 4 0}$ & 39,8 & 19,5 & 13,0 & 8,1 & 0,8 & 3,3 & 15,4 \\
\hline
\end{tabular}

Az almérnöki iskolába beiratkozott diákoknak csak egy kis része diplomázott le. Az 1933/1934-es tanévre beiratkozott növendékekhez viszonyítva az ez évben diplomát szerzettek aránya 37,1\% volt, a következő évben 11,5, míg 1935/1936-ban csak 6,5\%.

120. A kolozsvári Elektromechanikai Almérnöki Iskola diplomázott diákjai:

\begin{tabular}{|c|c|c|c|}
\hline & \multicolumn{3}{|c|}{ Diplomázottak } \\
\cline { 2 - 4 } & Férfi & Nő & Összesen \\
\hline $\mathbf{1 9 3 3 / 1 9 3 4}$ & 13 & - & 13 \\
\hline $\mathbf{1 9 3 4 / 1 9 3 5}$ & 6 & - & 6 \\
\hline $\mathbf{1 9 3 5 / 1 9 3 6}$ & 4 & - & 4 \\
\hline $\mathbf{1 9 3 6 / 1 9 3 7}$ & 16 & 1 & 17 \\
\hline $\mathbf{1 9 3 7 / 1 9 3 8}$ & 13 & - & 13 \\
\hline $\mathbf{1 9 3 8 / 1 9 3 9}$ & 15 & 1 & - \\
\hline $\mathbf{1 9 3 9 / 1 9 4 0}$ & - & - & 16 \\
\hline
\end{tabular}

\subsection{Agrártudományi Akadémia, Kolozsvár}

Az erdélyi agrártudományi tanulmányok hosszú múltra tekintenek vissza. 1869-ben jött létre a Kolozsvár melletti Monostoron egy agrártudományi intézet, amely 1906-ban az Agrárakadémia nevet vette fel. A névváltoztatás egyben azt is jelentette, hogy az intézmény felsőoktatási szintre emelkedett. Az első világháború alatt, egészen 1918-ig, az Akadémián szünetelt az oktatás.

Az újrainduló intézmény jelentős fejlesztésen ment keresztül. A képzés 4 éves időtartamú volt, 1922-től pedig a diplomázott diákok agrármérnöki címet kaptak. Néhány év múlva, 1929-ben az Agrárakadémia átalakult Agrártudományi Akadémiává (Academia de Înalte Studii Agronomice), a négyéves képzési időszakról az ötévesre tért át, és az intézmény a doktori címek odaítélésére is jogosulttá vált.

A kolozsvári Agrártudományi Akadémia diákjainak száma az 1920-as évek második felében meghaladta a százat, az 1930-as évek végén pedig már 300 felett volt. 1925 és 1937 között a diákok esetében négyszeres, a tanárok esetében pedig kétszeres növekedés figyelhető meg. A mérnöki diplomát szerzőknek a beiratkozott diákokhoz viszonyított aránya évenként 
változott. A legtöbb esetben 10-14\% között mozgott, 1926/1927-ben viszont felsőoktatási viszonylatban magas értéket ért el (28,6\%).

121. A kolozsvári Agrártudományi Akadémia diákjai, diplomázottai és tanárai:

\begin{tabular}{|c|c|c|c|c|c|c|c|c|}
\hline & \multicolumn{3}{|c|}{ Beiratkozott diákok } & \multicolumn{2}{c|}{ Mérnöki diplomát szereztek } & \multirow{2}{*}{ Tanári kar } \\
\cline { 2 - 8 } & Fiú & Lány & Összesen & Fiú & Lány & \multicolumn{2}{|c|}{ Összesen } & \\
\hline $\mathbf{1 9 2 5 / 1 9 2 6}$ & 73 & - & 73 & 9 & - & 9 & $12,3 \%$ & 22 \\
\hline $\mathbf{1 9 2 6 / 1 9 2 7}$ & 68 & 2 & 70 & 19 & 1 & 20 & $28,6 \%$ & 22 \\
\hline $\mathbf{1 9 2 7 / 1 9 2 8}$ & 101 & 1 & 102 & 12 & 3 & 15 & $14,7 \%$ & 21 \\
\hline $\mathbf{1 9 2 8 / 1 9 2 9}$ & 128 & 3 & 131 & 13 & 1 & 14 & $10,7 \%$ & 21 \\
\hline $\mathbf{1 9 2 9 / 1 9 3 0}$ & 153 & 4 & 157 & 15 & - & 15 & $9,6 \%$ & 20 \\
\hline $\mathbf{1 9 3 0 / 1 9 3 1}$ & 149 & 8 & 157 & 18 & 1 & 19 & $12,1 \%$ & 20 \\
\hline $\mathbf{1 9 3 1 / 1 9 3 2}$ & 170 & 14 & 184 & 20 & - & 20 & $10,9 \%$ & 20 \\
\hline $\mathbf{1 9 3 2 / 1 9 3 3}$ & 200 & 16 & 216 & 5 & - & 5 & $2,3 \%$ & 23 \\
\hline $\mathbf{1 9 3 3 / 1 9 3 4}$ & 305 & 26 & 331 & 25 & 1 & 26 & $7,9 \%$ & 21 \\
\hline $\mathbf{1 9 3 5 / 1 9 3 6}$ & 308 & 23 & 331 & 36 & 4 & 40 & $12,1 \%$ & 43 \\
\hline $\mathbf{1 9 3 6 / 1 9 3 7}$ & 301 & 22 & 323 & 53 & 7 & 60 & $18,6 \%$ & 42 \\
\hline $\mathbf{1 9 3 7 / 1 9 3 8}$ & 309 & 15 & 324 & 53 & 4 & 57 & $17,6 \%$ & 41 \\
\hline
\end{tabular}

A beiratkozott diákok etnikai megoszlására nézve az 1935-1937 közötti időszakból rendelkezünk adatokkal. Ekkor a nemzetiségi és felekezeti megoszlás teljesen ellentétes képet mutatott az 1918 előttihez képest. A korábban a magyar dzsentrik iskolájaként működő intézmény a két világháború között román jellegüvé vált. A román diákok nyolcvanhárom-nyolcvanhét százalékot, a magyarok 6-8-at, míg a németek három-négy százalékot alkottak az 1930-as évek második felében. A vallási összetétel hasonlóan alakult. A görögkeleti és görög katolikus diákok aránya nyolcvan százalék fölött volt, őket a római katolikusok követték, majd a reformátusok, evangélikusok és unitáriusok. Az izraeliták aránya elenyésző volt.

122. A kolozsvári Agrártudományi Akadémia diákjainak nemzetiségi megoszlása:

\begin{tabular}{|c|c|c|c|c|c|c|c|c|c|c|c|}
\hline & \multicolumn{11}{|c|}{ Beiratkozott diákok nemzetisége } \\
\hline & \multicolumn{2}{|c|}{ Román } & \multicolumn{2}{|c|}{ Német } & \multicolumn{2}{|c|}{ Magyar } & \multicolumn{2}{|c|}{ Zsidó } & \multicolumn{2}{|c|}{ Egyéb } & \multirow{2}{*}{ Összesen } \\
\hline & & $\%$ & & $\%$ & & $\%$ & & $\%$ & & $\%$ & \\
\hline $1935 / 1936$ & 289 & 87,3 & 12 & 3,6 & 19 & 5,7 & 1 & 0,3 & 10 & 3,0 & 331 \\
\hline $1936 / 1937$ & 269 & 83,3 & 11 & 3,4 & 24 & 7,4 & 1 & 0,3 & 18 & 5,6 & 323 \\
\hline $1937 / 1938$ & 278 & 85,8 & 13 & 4,0 & 26 & 8,0 & - & - & 7 & 2,2 & 324 \\
\hline
\end{tabular}


123. A kolozsvári Agrártudományi Akadémia diákjainak felekezeti megoszlása:

\begin{tabular}{|c|c|c|c|c|c|c|c|c|c|}
\hline & \multicolumn{9}{|c|}{ Beiratkozott diákok vallása } \\
\hline & 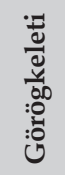 & 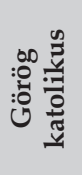 & 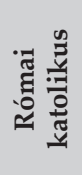 & 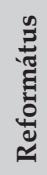 & & 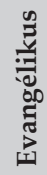 & & 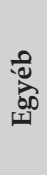 & 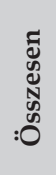 \\
\hline $1935 / 1936$ & 230 & 65 & 17 & 6 & 4 & 5 & 1 & 1 & 329 \\
\hline $1936 / 1937$ & 220 & 58 & 16 & 9 & 6 & 8 & 1 & 2 & 320 \\
\hline $1937 / 1938$ & 207 & 73 & 23 & 9 & 6 & 5 & - & 1 & 324 \\
\hline
\end{tabular}

124. A kolozsvári Agrártudományi Akadémia diákjainak felekezeti megoszlása, százalékban kifejezve:

\begin{tabular}{|c|c|c|c|c|c|c|c|}
\hline & \multicolumn{7}{|c|}{ Beiratkozott diákok vallása } \\
\hline & 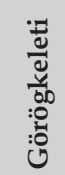 & 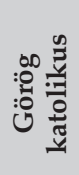 & 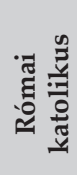 & 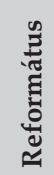 & 胥 & 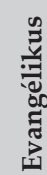 & 䒕 \\
\hline $1935 / 1936$ & 69,9 & 19,8 & 5,2 & 1,8 & 1,2 & 1,5 & 0,3 \\
\hline 1936/1937 & 68,8 & 18,1 & 5,0 & 2,8 & 1,9 & 2,5 & 0,3 \\
\hline $1937 / 1938$ & 63,9 & 22,5 & 7,1 & 2,8 & 1,9 & 1,5 & - \\
\hline
\end{tabular}

Az 1938-as felsőoktatási törvény értelmében az Agrárakadémiát a temesvári Műszaki Egyetemnek rendelték alá. Mindez azt jelentette, hogy 1938-tól megszűnt intézményi önállósága, és a továbbiakban a temesvári Politechnika Mezőgazdasági Karaként müködött tovább egészen 1948-ig. 1940-ben, a második bécsi döntést követően, a Mezőgazdasági Kar Kolozsvárról Temesvárra menekült, ahonnan 1945-ben tért vissza eredeti székhelyére (Drăgoescu 1999: 1211).

\subsection{Felsőkereskedelmi és Ipari Akadémia, Kolozsvár-Brassó}

Az erdélyi egyetemi szintű közgazdasági oktatás a kolozsvári Kereskedelmi Akadémia 1902-es megnyitásával vette kezdetét. Az intézmény 1922-ig múködött ezen név alatt. 1922-ben az intézményt a bukaresti hasonló profilú felsőoktatási intézmény mintájára szervezték újjá Felsőkereskedelmi és Ipari Akadémia néven (Academia de Inalte Studii Comerciale) (Dare de Seamă 1922: 3-22). 
A kolozsvári Felsőkereskedelmi és Ipari Akadémiára az 1920-1927 közötti időszakban beiratkozott diákok száma fokozatosan nőtt. Az első tanévre alig 39 diákot vettek fel, egy év múlva már 107 volt a számuk, 1924/1925-ben pedig 290. Az ezt követő években enyhe visszaesés tapasztalható a diákok számát illetően, 1930-tól viszont újabb gyarapodásnak lehetünk a tanúi. Ez elsősorban annak volt köszönhető, hogy 1930. január 1-től megváltozott az intézmény státusa. Ettől kezdődően a korábbi 3 éves képzés 4 évesre bővült, amelyből az első év előkészítő év volt, és az Akadémia doktori címek kibocsátására is jogosulttá vált (Drăgoescu 1999: 1098-1099., Dare de seamă 1922: 26, 1924: 36 és 48, 1926: 35 és 50, 1929: 56 és 66., Anuarul Statistic 1933: 364, 1939: 250 és 252).

Az 1930-1937-es periódusban 460-960 között iratkoztak be, látható tehát, hogy az 1920-as évek elejéhez képest megduplázódott a diáklétszám. Mindez viszont nem feltétlenül járt együtt az oktatás minőségének javulásával. Legalábbis az a tény, hogy 1923-ban tíz, de 1934-ben is csak 66 diák szerzett diplomát az intézetben, igen nagyarányú lemorzsolódást jelez (lásd a 129. sz. táblázatot).

Részletes adatokkal az 1930-at követő időszakról rendelkezünk. A diákok többsége fiú volt, a lányok aránya az 1930-as évek elején 30-32\%, később viszont visszaesett és 1936/1937-ben már csak 9,5\%-ra rúgott.

125. A kolozsvári Felsőkereskedelmi és Ipari Akadémia diákjainak nemi megoszlása 1931-1937 között:

\begin{tabular}{|c|c|c|c|c|c|c|c|c|c|c|c|c|c|}
\hline & \multicolumn{12}{|c|}{ Beiratkozott diákok nemzetisége } & \multirow{3}{*}{ 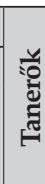 } \\
\hline & \multicolumn{2}{|c|}{ Román } & \multicolumn{2}{|c|}{ Német } & \multicolumn{2}{|c|}{ Magyar } & \multicolumn{2}{|c|}{ Zsidó } & \multirow{2}{*}{$\begin{array}{c}\text { Egyéb } \\
\text { Fiú }\end{array}$} & \multicolumn{2}{|c|}{ Összesen } & \multirow{2}{*}{ 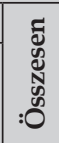 } & \\
\hline & Fiú & Lány & Fiú & Lány & Fiú & Lány & Fiú & Lány & & Fiú & Lány & & \\
\hline 1931/1932 & 254 & 97 & 20 & 2 & 40 & 28 & 6 & 9 & 7 & 326 & 137 & 463 & \\
\hline 1932/1933 & 292 & 115 & 18 & 3 & 47 & 34 & 10 & 17 & 4 & 370 & 170 & 540 & \\
\hline $1933 / 1934$ & 384 & 83 & 25 & 2 & 57 & 33 & 21 & 19 & 5 & 492 & 137 & 629 & \\
\hline $1935 / 1936$ & 689 & 71 & 19 & 2 & 46 & 21 & 17 & 12 & 7 & 778 & 106 & 884 & 29 \\
\hline $1936 / 1937$ & \begin{tabular}{|l|}
795 \\
\end{tabular} & 69 & 17 & 2 & 41 & 16 & 15 & 4 & 8 & 875 & 92 & 967 & 28 \\
\hline $1937 / 1938$ & \begin{tabular}{|l|}
693 \\
\end{tabular} & 66 & 12 & 14 & 33 & 11 & 6 & 4 & 6 & 750 & 95 & 845 & 28 \\
\hline
\end{tabular}

Nemzetiségi megoszlás tekintetében a román nemzetiségű hallgatók képezték a túlnyomó többséget. Őket a magyarok követték öt-tizenegy százalékkal, a zsidók egy-tizenöt százalékkal és a németek kettő-öt százalékkal. Hasonló módon a diákok felekezeti megoszlása is erőteljes görögkeleti és görög katolikus fölényt mutatott. A római katolikusok négy-hét százalékot, a reformátusok két százalékot tettek ki. 
126. A kolozsvári Felsókereskedelmi és Ipari Akadémia diákjainak nemzetiségi megoszlása:

\begin{tabular}{|c|c|c|c|c|c|c|c|c|c|c|}
\hline & \multicolumn{10}{|c|}{ Beiratkozott diákok } \\
\hline & \multicolumn{2}{|c|}{ Román } & \multicolumn{2}{|c|}{ Magyar } & \multicolumn{2}{|c|}{ Német } & \multicolumn{2}{|c|}{ Zsidó } & \multirow{2}{*}{ Egyéb } & \multirow{2}{*}{ Összesen } \\
\hline & & $\%$ & & $\%$ & & $\%$ & & $\%$ & & \\
\hline $1920 / 1921$ & 38 & 97,4 & - & - & - & - & - & - & 1 & 39 \\
\hline $1921 / 1922$ & 93 & 86,9 & 6 & 5,6 & 3 & 2,8 & 3 & 2,8 & 2 & 107 \\
\hline $1922 / 1923$ & 189 & 82,9 & 26 & 11,4 & 7 & 3,1 & 4 & 1,8 & 2 & 228 \\
\hline 1923/1924 & 184 & 86,4 & 12 & 5,6 & 9 & 4,2 & 5 & 2,3 & 3 & 213 \\
\hline $1924 / 1925$ & 236 & 81,4 & 21 & 7,2 & 12 & 4,1 & 7 & 2,4 & 14 & 290 \\
\hline $1925 / 1926$ & 215 & 81,7 & 27 & 10,3 & 9 & 3,4 & 7 & 2,7 & 5 & 263 \\
\hline $1926 / 1927$ & 193 & 74,8 & 29 & 11,2 & 16 & 6,2 & 9 & 3,5 & 11 & 258 \\
\hline $1927 / 1928$ & 215 & 81,7 & 29 & 11,0 & 10 & 3,8 & 4 & 1,5 & 5 & 263 \\
\hline $1931 / 1932$ & 351 & 75,8 & 68 & 14,7 & 22 & 4,8 & 15 & 3,2 & 7 & 463 \\
\hline $1932 / 1933$ & 407 & 75,4 & 81 & 15,0 & 21 & 3,9 & 27 & 5,0 & 4 & 540 \\
\hline $1933 / 1934$ & 467 & 74,2 & 90 & 14,3 & 27 & 4,3 & 40 & 6,4 & 5 & 629 \\
\hline $1935 / 1936$ & 760 & 86,0 & 67 & 7,6 & 21 & 2,4 & 29 & 3,3 & 7 & 884 \\
\hline $1936 / 1937$ & 864 & 89,3 & 57 & 5,9 & 19 & 2,0 & 19 & 2,0 & 8 & 967 \\
\hline $1937 / 1938$ & 759 & 89,8 & 44 & 5,2 & 26 & 3,1 & 10 & 1,2 & 6 & 845 \\
\hline
\end{tabular}

127. A kolozsvári Felsókereskedelmi és Ipari Akadémia diákjainak felekezeti megoszlása:

\begin{tabular}{|c|c|c|c|c|c|c|c|c|c|}
\hline & \multicolumn{9}{|c|}{ Beiratkozott diákok vallása } \\
\hline & 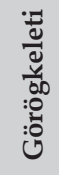 & 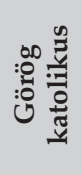 & 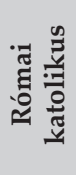 & 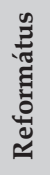 & 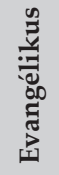 & & 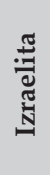 & 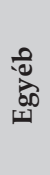 & 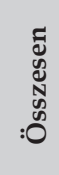 \\
\hline 1920/1921 & 23 & 15 & 1 & - & - & - & - & - & 39 \\
\hline 1921/1922 & 64 & 29 & 5 & 2 & 3 & 1 & 3 & - & 107 \\
\hline 1922/1923 & 137 & 53 & 14 & 8 & 7 & 5 & 4 & - & 228 \\
\hline 1923/1924 & 140 & 45 & 9 & 5 & 8 & 1 & 5 & - & 213 \\
\hline $1924 / 1925$ & 209 & 40 & 14 & 6 & 12 & 2 & 7 & - & 290 \\
\hline $1925 / 1926$ & 177 & 39 & 12 & 11 & 9 & 4 & 7 & 4 & 263 \\
\hline $1926 / 1927$ & 159 & 46 & 13 & 13 & 14 & 4 & 9 & - & 258 \\
\hline $1927 / 1928$ & 157 & 59 & 24 & 8 & 8 & 3 & 4 & - & 263 \\
\hline $1935 / 1936$ & 636 & 126 & 62 & 19 & 3 & 6 & 29 & 3 & 884 \\
\hline $1936 / 1937$ & 746 & 114 & 52 & 19 & 2 & 11 & 19 & 4 & 967 \\
\hline $1937 / 1938$ & 656 & 112 & 34 & 15 & 10 & 3 & 10 & 5 & 845 \\
\hline
\end{tabular}


128. A kolozsvári Felsókereskedelmi és Ipari Akadémia diákjainak felekezeti megoszlása, százalékban kifejezve:

\begin{tabular}{|c|c|c|c|c|c|c|c|}
\hline & \multicolumn{7}{|c|}{ Beiratkozott diákok vallása } \\
\hline & 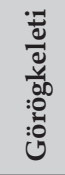 & 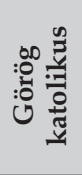 & 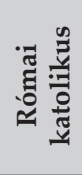 & 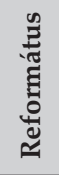 & 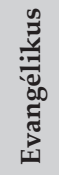 & & 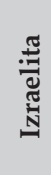 \\
\hline $1920 / 1921$ & 59,0 & 38,5 & 2,6 & - & - & - & - \\
\hline 1921/1922 & 59,8 & 27,1 & 4,7 & 1,9 & 2,8 & 0,9 & 2,8 \\
\hline $1922 / 1923$ & 60,1 & 23,2 & 6,1 & 3,5 & 3,1 & 2,2 & 1,8 \\
\hline $1923 / 1924$ & 65,7 & 21,1 & 4,2 & 2,3 & 3,8 & 0,5 & 2,3 \\
\hline $1924 / 1925$ & 72,1 & 13,8 & 4,8 & 2,1 & 4,1 & 0,7 & 2,4 \\
\hline $1925 / 1926$ & 67,3 & 14,8 & 4,6 & 4,2 & 3,4 & 1,5 & 2,7 \\
\hline $1926 / 1927$ & 61,6 & 17,8 & 5,0 & 5,0 & 5,4 & 1,6 & 3,5 \\
\hline $1927 / 1928$ & 59,7 & 22,4 & 9,1 & 3,0 & 3,0 & 1,1 & 1,5 \\
\hline $1935 / 1936$ & 71,9 & 14,3 & 7,0 & 2,1 & 0,3 & 0,7 & 3,3 \\
\hline $1936 / 1937$ & 77,1 & 11,8 & 5,4 & 2,0 & 0,2 & 1,1 & 2,0 \\
\hline $1937 / 1938$ & 77,6 & 13,3 & 4,0 & 1,8 & 1,2 & 0,4 & 1,2 \\
\hline
\end{tabular}

A Felsőkereskedelmi Akadémia végzőseiről az 1923-1934 közötti időszakra nézve rendelkezünk kimutatásokkal. Ezek alatt az évek alatt összesen 570 személy szerzett diplomát, amely évi 41-71 licenciátust jelentett.

129. A Felsókereskedelmi és Ipari Akadémia diplomázottainak száma 1923-1934 között:

\begin{tabular}{|c|c|c|c|c|c|c|c|c|c|c|c|}
\hline 1923 & 1924 & $\mathbf{1 9 2 5}$ & $\mathbf{1 9 2 6}$ & $\mathbf{1 9 2 7}$ & $\mathbf{1 9 2 8}$ & $\mathbf{1 9 2 9}$ & $\mathbf{1 9 3 0}$ & $\mathbf{1 9 3 1}$ & $\mathbf{1 9 3 2}$ & $\mathbf{1 9 3 3}$ & $\mathbf{1 9 3 4}$ \\
\hline 10 & 37 & 53 & 47 & 47 & 46 & 45 & 65 & 42 & 41 & 71 & 66 \\
\hline
\end{tabular}

A második bécsi döntést követően a kolozsvári Felsőkereskedelmi és Ipari Akadémia a Romániánál maradt Brassóba helyezte át a székhelyét, ahol 1940-1948 között müködött ezen a néven. Az 1948-as román tanügyi reformot követően az Akadémiát megszüntették, és helyette új, hároméves képzést nyújtó oktatási intézményt hoztak létre Gazdaságtudományi és Tervezési Intézet (Institutul de Ştiințe Economice şi Planificare) névvel. Az Intézet székhelyét 1950-ben Iaşi-ba helyezték át (Drăgoescu 1999: 1101, Chiriacescu 1998).

1938-1948 között a következő módon alakult a Felsőkereskedelmi és Ipari Akadémia diákjainak létszáma (Drăgoescu 1999: 1099): 
130. A Felsőkereskedelmi és Ipari Akadémia diákjainak száma 1938-1947 között:

\begin{tabular}{|l|c|c|}
\hline & Év & Diákok száma \\
\hline \multirow{3}{*}{ Kolozsvár } & $1938 / 1939$ & 738 \\
\hline \multirow{4}{*}{ Brassó } & $1939 / 1940$ & 622 \\
\cline { 2 - 3 } & $1940 / 1941$ & 1024 \\
\cline { 2 - 3 } & $1941 / 1942$ & 520 \\
\cline { 2 - 3 } & $1942 / 1943$ & 540 \\
\cline { 2 - 3 } & $1943 / 1944$ & 704 \\
\cline { 2 - 3 } & $1944 / 1945$ & 560 \\
\cline { 2 - 3 } & $1945 / 1946$ & 1128 \\
\cline { 2 - 3 } & $1946 / 1947$ & 1744 \\
\hline
\end{tabular}

\subsection{A kolozsvári Zene- és Színmúvészeti Akadémia, valamint a temesvári Szépmúvészeti Iskola}

A kolozsvári Zene- és Színmúvészeti Akadémia hallgatóinak száma az 1930-as évek második felében meghaladta a kétszázat. A beiratkozott lánydiákok harminckilenc-negyvenegy százalékot alkottak. A hallgatóknak közel kétharmada volt román nemzetiségú és görögkeleti vagy görög katolikus vallású, 15-18\% volt magyar, és 9-10\% német. A zsidók hét-nyolc százalékot tettek ki. A kisebbségi felekezetekhez tartozó diákok alulreprezentáltsága nyilvánvaló. Többségük a római katolikus $(13 \%)$, református (5-11\%), evangélikus (4-9\%) és izraelita (7-8\%) felekezethez tartozott.

131. A kolozsvári Zene-és Színmúvészeti Akadémia diákjainak nemi megoszlása és tanárai:

\begin{tabular}{|l|c|c|c|c|}
\hline \multirow{2}{*}{} & \multirow{2}{*}{ Tanári kar } & \multicolumn{3}{|c|}{ Beiratkozott diákok } \\
\cline { 3 - 5 } & & Fiú & Lány & Összesen \\
\hline $\mathbf{1 9 3 5 / 1 9 3 6}$ & 25 & 138 & 95 & 233 \\
\hline $\mathbf{1 9 3 6 / 1 9 3 7}$ & 23 & 136 & 90 & 226 \\
\hline $\mathbf{1 9 3 7 / 1 9 3 8}$ & 29 & 137 & 88 & 225 \\
\hline
\end{tabular}

132. A kolozsvári Zene-és Színmúvészeti Akadémia diákjainak nemzetiségi megoszlása:

\begin{tabular}{|c|c|c|c|c|c|c|c|c|c|c|c|}
\hline & \multicolumn{11}{|c|}{ Beiratkozott diákok nemzetisége } \\
\hline & \multicolumn{2}{|c|}{ Román } & \multicolumn{2}{|c|}{ Magyar } & \multicolumn{2}{|c|}{ Német } & \multicolumn{2}{|c|}{ Zsidó } & \multicolumn{2}{|c|}{ Egyéb } & \multirow{2}{*}{ Összesen } \\
\hline & & $\%$ & & $\%$ & & $\%$ & & $\%$ & & $\%$ & \\
\hline $1935 / 1936$ & 149 & 63,9 & 42 & 18,0 & 24 & 10,3 & 16 & 6,9 & 2 & 0,9 & 233 \\
\hline $1936 / 1937$ & 149 & 65,9 & 34 & 15,0 & 22 & 9,7 & 17 & 7,5 & 4 & 1,8 & 226 \\
\hline $1937 / 1938$ & 140 & 62,2 & 41 & 18,2 & 20 & 8,9 & 18 & 8,0 & 6 & 2,7 & 225 \\
\hline
\end{tabular}


133. A kolozsvári Zene-és Színmüvészeti Akadémia diákjainak felekezeti megoszlása:

\begin{tabular}{|c|c|c|c|c|c|c|c|c|c|}
\hline & \multicolumn{9}{|c|}{ Beiratkozott diákok vallása } \\
\hline & 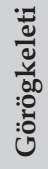 & 苞 & 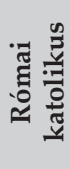 & 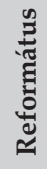 & & 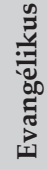 & 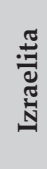 & 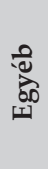 & 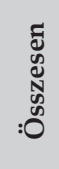 \\
\hline $1935 / 1936$ & 75 & 71 & 31 & 12 & 4 & 20 & 16 & 4 & 233 \\
\hline $1936 / 1937$ & 81 & 66 & 29 & 18 & 2 & 10 & 17 & 3 & 226 \\
\hline $1937 / 1938$ & 67 & 69 & 30 & 24 & 4 & 10 & 18 & 3 & 225 \\
\hline
\end{tabular}

134. A kolozsvári Zene-és Színmüvészeti Akadémia diákjainak felekezeti megoszlása, százalékban kifejezve:

\begin{tabular}{|c|c|c|c|c|c|c|c|c|}
\hline & \multicolumn{8}{|c|}{ Beiratkozott diákok vallása } \\
\hline & 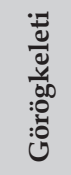 & 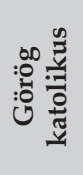 & 䒕 & 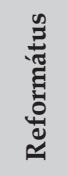 & & 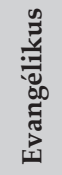 & 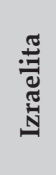 & 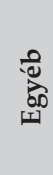 \\
\hline $1935 / 1936$ & 32,2 & 30,5 & 13,3 & 5,2 & 1,7 & 8,6 & 6,9 & 1,7 \\
\hline $1936 / 1937$ & 35,8 & 29,2 & 12,8 & 8,0 & 0,9 & 4,4 & 7,5 & 1,3 \\
\hline $1937 / 1938$ & 29,8 & 30,7 & 13,3 & 10,7 & 1,8 & 4,4 & 8,0 & 1,3 \\
\hline
\end{tabular}

Első éveiben a Szépművészeti Iskola (Şcoala de Arte Frumoase) Kolozsváron müködött (1925-1933), majd innen helyezték át székhelyét Temesvárra (1933-1941). Nyilvánossági jogot 1930-ban kapott, az 1936/1937-es tanévtől pedig akadémiai rangra emelkedett (Academia de Arte Frumoase din Timişoara) (Lăptoiu 1999: 120). 1941-ben középiskolává minősítették vissza.

A Szépművészeti Iskola volt az első olyan erdélyi felsőoktatási intézmény, amely a szépművészetek terén nyújtott képzést. Az első évben 67 , a következőben 91, 1927/1928-ban pedig már 120 diák iratkozott be (Lăptoiu 1999: 28). Később viszont csökkent a számuk, de így is, az 1932/1933-as tanévig 738 volt az évek során beiratkozottak száma. Közülük 625-en látogatták ténylegesen is az órákat (Lăptoiu 1999: 107).

Az 1935-1937 közötti időszakban évenként mintegy félszáz diák tanult itt, a beiratkozott hallgatóinak közel fele volt nő. A román nemzetiségü hallgatók aránya 57-62\% között mozgott, a magyaroké 16-26\%, a németeké $10-13 \%$, a zsidóké pedig $2-4 \%$ között. A legtöbb diák a görögkeleti felekezethez tartozott, őket a római katolikusok, reformátusok és izraeliták követték. 
135. A temesvári Szépmüvészeti Iskola diákjainak nemi megoszlása és tanárai:

\begin{tabular}{|c|c|c|c|c|}
\hline \multirow{2}{*}{} & \multirow{2}{*}{ Tanári kar } & \multicolumn{3}{|c|}{ Beiratkozott diákok } \\
\cline { 3 - 5 } & & Férfi & Nő & Összesen \\
\hline $\mathbf{1 9 3 5 / 1 9 3 6}$ & 9 & 21 & 21 & 42 \\
\hline $\mathbf{1 9 3 6 / 1 9 3 7}$ & 9 & 28 & 22 & 50 \\
\hline $\mathbf{1 9 3 7 / 1 9 3 8}$ & 7 & 24 & 23 & 47 \\
\hline
\end{tabular}

136. A temesvári Szépmüvészeti Iskola diákjainak nemzetiségi megoszlása:

\begin{tabular}{|c|c|c|c|c|c|c|c|c|c|c|c|}
\hline & \multicolumn{11}{|c|}{ Beiratkozott diákok nemzetisége } \\
\hline & \multicolumn{2}{|c|}{ Román } & \multicolumn{2}{|c|}{ Magyar } & \multicolumn{2}{|c|}{ Német } & \multicolumn{2}{|c|}{ Zsidó } & \multicolumn{2}{|c|}{ Egyéb } & \multirow{2}{*}{ Összesen } \\
\hline & & $\%$ & & $\%$ & & $\%$ & & $\%$ & & $\%$ & \\
\hline $1935 / 1936$ & 24 & 57,1 & 11 & 26,2 & 4 & 9,5 & 1 & 2,4 & 2 & 4,8 & 42 \\
\hline $1936 / 1937$ & 31 & 62,0 & 8 & 16,0 & 6 & 12,0 & 2 & 4,0 & 3 & 6,0 & 50 \\
\hline $1937 / 1938$ & 29 & 61,7 & 8 & 17,0 & 6 & 12,8 & 2 & 4,3 & 2 & 4,3 & 47 \\
\hline
\end{tabular}

137. A temesvári Szépmúvészeti Iskola diákjainak felekezeti megoszlása:

\begin{tabular}{|c|c|c|c|c|c|c|c|c|c|c|c|c|c|}
\hline & \multicolumn{13}{|c|}{ Beiratkozott diákok vallása } \\
\hline & \multicolumn{2}{|c|}{ 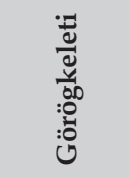 } & \multicolumn{2}{|c|}{ 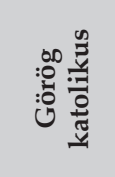 } & \multicolumn{2}{|c|}{ 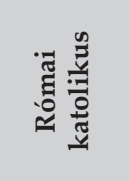 } & \multicolumn{2}{|c|}{ 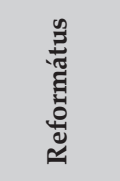 } & \multicolumn{2}{|c|}{ 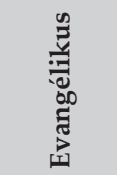 } & \multicolumn{2}{|c|}{ 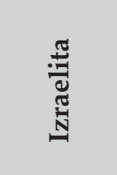 } & \multirow[t]{2}{*}{ 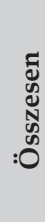 } \\
\hline & & $\%$ & & $\%$ & & $\%$ & & $\%$ & & $\%$ & & $\%$ & \\
\hline $1935 / 1936$ & 20 & 47,6 & 2 & 4,8 & 13 & 31,0 & 5 & 11,9 & 1 & 2,4 & 1 & 2,4 & 42 \\
\hline $1936 / 1937$ & 26 & 52,0 & 4 & 8,0 & 12 & 24,0 & 4 & 8 & 2 & 4,0 & 2 & 4,0 & 50 \\
\hline $1937 / 1938$ & 26 & 55,3 & 3 & 6,4 & 12 & 25,5 & 4 & 8,5 & - & - & 2 & 4,3 & 47 \\
\hline
\end{tabular}

\subsection{Müszaki Főiskola (Politechnika), Temesvár}

Az 1920-ban Temesváron létrehozott Müszaki Főiskolára a két világháború között évente néhány száz diák iratkozott be, 1923-1937 alatt alig nőtt a számuk. Ezzel szemben, az intézményt érintő fejlesztések velejárójaként, a tanári kar megduplázódott. Mérnöki diplomát a hallgatók egytizede szerzett. A diákok szinte kizárólag fiúkból álltak és nyolcvanegy százalékuk román nemzetiségü volt. A magyarok hat-hét százalékot, a németek ötöt tettek ki, zsidók pedig alig voltak. A görögkeletiek és görög katolikusok együttes aránya meghaladta a nyolcvanhat százalékot, magukban foglalva a román nemzetiségü diákokat, valamint főként e két vallást követő orosz, rutén, görög hallgatókat. A hallgatók körében tapasztalható román túlsúly lényegében a két világháború közötti müszaki mérnöki elitben bekövetkező etnikai váltást is előrevetíti. 
138. A temesvári Müszaki Főiskola diákjainak nemi megoszlása, a diplomázottak száma és a tanári kar:

\begin{tabular}{|c|c|c|c|c|c|c|}
\hline & \multicolumn{3}{|c|}{ Beiratkozott diákok } & \multicolumn{2}{c|}{$\begin{array}{c}\text { Mérnöki diplomát } \\
\text { szereztek }\end{array}$} & \multirow{2}{*}{ Tanári kar } \\
\cline { 2 - 6 } & Fiú & Lány & Összesen & Fiú & Lány & \\
\hline $\mathbf{1 9 2 3 / 1 9 2 4}$ & 338 & - & 338 & 21 & - & 34 \\
\hline $\mathbf{1 9 2 4 / 1 9 2 5}$ & 324 & - & 324 & 29 & - & 42 \\
\hline $\mathbf{1 9 2 5 / 1 9 2 6}$ & 305 & - & 305 & 33 & - & 45 \\
\hline $\mathbf{1 9 2 6 / 1 9 2 7}$ & 327 & 1 & 328 & 60 & - & 47 \\
\hline $\mathbf{1 9 2 7 / 1 9 2 8}$ & 396 & 1 & 397 & 73 & - & 56 \\
\hline $\mathbf{1 9 2 8 / 1 9 2 9}$ & 406 & - & 406 & 54 & - & 57 \\
\hline $\mathbf{1 9 2 9 / 1 9 3 0}$ & 408 & - & 408 & 44 & - & 57 \\
\hline $\mathbf{1 9 3 0 / 1 9 3 1}$ & 415 & - & 415 & 44 & - & 69 \\
\hline $\mathbf{1 9 3 1 / 1 9 3 2}$ & 356 & 1 & 357 & 30 & - & 62 \\
\hline $\mathbf{1 9 3 2 / 1 9 3 3}$ & 391 & 3 & 394 & 50 & - & 57 \\
\hline $\mathbf{1 9 3 3 / 1 9 3 4}$ & 427 & 1 & 428 & 34 & - & 63 \\
\hline $\mathbf{1 9 3 5 / 1 9 3 6}$ & 517 & 3 & 520 & $?$ & $?$ & 67 \\
\hline $\mathbf{1 9 3 6 / 1 9 3 7}$ & 415 & 5 & 420 & $?$ & $?$ & 67 \\
\hline $\mathbf{1 9 3 7 / 1 9 3 8}$ & 395 & 2 & 397 & 51 & 1 & 67 \\
\hline
\end{tabular}

139. A temesvári Múszaki Föiskola diákjainak nemzetiségi megoszlása: ${ }^{22}$

\begin{tabular}{|c|c|c|c|c|c|c|c|c|c|c|c|}
\hline & \multicolumn{11}{|c|}{ Beiratkozott diákok nemzetisége } \\
\hline & \multicolumn{2}{|c|}{ Román } & \multicolumn{2}{|c|}{ Német } & \multicolumn{2}{|c|}{ Magyar } & \multicolumn{2}{|c|}{ Zsidó } & \multicolumn{2}{|c|}{ Egyéb } & \multirow{2}{*}{ Összesen } \\
\hline & & $\%$ & & $\%$ & & $\%$ & & $\%$ & & $\%$ & \\
\hline $1935 / 1936$ & 421 & 81,0 & 19 & 3,7 & 37 & 7,1 & 2 & 0,4 & 41 & 7,9 & 520 \\
\hline $1936 / 1937$ & 340 & 81,0 & 16 & 3,8 & 29 & 6,9 & 1 & 0,2 & 34 & 8,1 & 420 \\
\hline $1937 / 1938$ & 320 & 80,6 & 17 & 4,3 & 25 & 6,3 & - & - & 35 & 8,8 & 397 \\
\hline
\end{tabular}

140. A temesvári Müszaki Főiskola diákjainak felekezeti megoszlása:

\begin{tabular}{|c|c|c|c|c|c|c|c|c|c|}
\hline & \multicolumn{9}{|c|}{ Beiratkozott diákok vallása } \\
\hline & 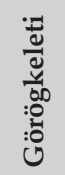 & 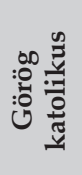 & 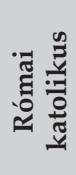 & 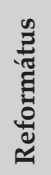 & م & 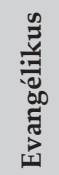 & 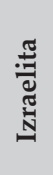 & 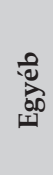 & 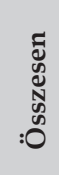 \\
\hline $1935 / 1936$ & 393 & 59 & 48 & 8 & 2 & 6 & 2 & 2 & 520 \\
\hline 1936/1937 & 312 & 49 & 44 & 5 & 2 & 4 & 1 & 3 & 420 \\
\hline 1937/1938 & 288 & 57 & 40 & 4 & 3 & 3 & - & 2 & 397 \\
\hline
\end{tabular}

${ }^{22} \mathrm{Az}$ Egyéb kategória ebben az esetben a Bánságban és Máramaros vidékén nagyobb számban élő oroszokat, ruténokat, bolgárokat, cseheket, szlovákokat, lengyeleket, görögöket, valamint nem román állampolgárokat takar. 
141. A temesvári Müszaki Főiskola diákjainak felekezeti megoszlása, százalékban kifejezve:

\begin{tabular}{|c|c|c|c|c|c|c|c|}
\hline & \multicolumn{7}{|c|}{ Beiratkozott diákok vallása } \\
\hline & 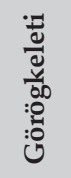 & 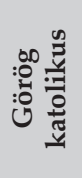 & 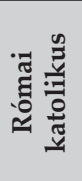 & 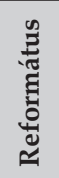 & 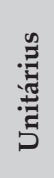 & 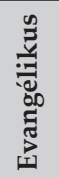 & \\
\hline $1935 / 1936$ & 75,6 & 11,3 & 9,2 & 1,5 & 0,4 & 1,2 & 0,4 \\
\hline 1936/1937 & 74,3 & 11,7 & 10,5 & 1,2 & 0,5 & 1,0 & 0,2 \\
\hline $1937 / 1938$ & 72,5 & 14,4 & 10,1 & 1,0 & 0,8 & 0,8 & - \\
\hline
\end{tabular}

A Müszaki Főiskolán 1937-től doktori címet is lehetett szerezni, de az első doktori címet 1939-ben ítélték oda itt. 1944-ig tíz hallgató doktorált le a Főiskolán. Az 1948-as oktatási reformot követően az intézmény a korábbi két fakultás mellett még kettővel bővült, a következőket foglalva magában: Mechanika, Elektrotechnika, Építészet, Ipari kémia (Drăgoescu 1999: 1193). 1948/1949-ben már 3655 diák tanult a Politechnikán (Anuarul Statistic 1957: 200).

\subsection{Jogi Akadémia, Nagyvárad}

A nagyváradi Jogi Akadémia múltja Mária Terézia korára nyúlik viszsza. Az uralkodónő a Ratio Educationis révén öt Királyi Akadémiát hozott létre Győrött, Kassán, Nagyszombaton, Nagyváradon és Zágrábban. A nagyváradi intézmény 1780-ban kezdte meg a müködését, de nem müködött folyamatosan. Az első világháborút követően, 1919 áprilisában a Jogi Akadémiát az erdélyi Kormányzótanács felügyelete alá helyezték, ugyanez év őszén pedig románosították. 1931-től az intézmény II. Károly Királyi Jogi Akadémia néven müködött, a következő évtől viszont megszünt az önállósága. Az új román egyetemi oktatási törvény értelmében a Jogi Akadémiát előbb a Bukaresti Egyetemhez csatolták (1932-1934), 1934-ben pedig beolvasztották a kolozsvári egyetem jogi tanszékébe (Fleisz 2005: 165-168).

Ajogi akadémia két világháború közötti müködésére nézve szinte teljes adatsorokkal rendelkezünk. 1921 és 1932 között a felsőoktatási intézmény diáklétszáma megduplázódott, ugyanakkor a fiú- és lánydiákok közötti arány is jelentős mértékben megváltozott. A kezdeti 0,3-ről 1932-re 8,8\%-ra emelkedett a női hallgatók aránya. Az államvizsgázott diákok többsége román és zsidó nemzetiségü volt. 
142. A nagyváradi Jogi Akadémia diákjainak és diplomázottainak nemi megoszlása, valamint a tanári kar:

\begin{tabular}{|c|c|c|c|c|c|c|c|}
\hline & \multicolumn{3}{|c|}{ Beiratkozott diákok } & \multicolumn{2}{c|}{ Államvizsgát tettek } & Tanári \\
\cline { 2 - 7 } & Férfi & Nö & Összesen & Férfi & Nő & Összesen & kar \\
\hline $\mathbf{1 9 2 1 / 1 9 2 2}$ & 380 & 1 & 381 & 12 & - & 12 & 12 \\
\hline $\mathbf{1 9 2 2 / 1 9 2 3}$ & 292 & 1 & 293 & 8 & - & 8 & 12 \\
\hline $\mathbf{1 9 2 3 / 1 9 2 4}$ & 190 & 5 & 195 & 42 & - & 42 & 16 \\
\hline $\mathbf{1 9 2 4 / 1 9 2 5}$ & 188 & 7 & 195 & - & - & - & 16 \\
\hline $\mathbf{1 9 2 5 / 1 9 2 6}$ & 254 & 8 & 262 & 31 & - & 31 & 11 \\
\hline $\mathbf{1 9 2 6 / 1 9 2 7}$ & 277 & 13 & 290 & 48 & 1 & 49 & 11 \\
\hline $\mathbf{1 9 2 7 / 1 9 2 8}$ & 259 & 15 & 274 & 43 & - & 43 & 12 \\
\hline $\mathbf{1 9 2 8 / 1 9 2 9}$ & 279 & 32 & 311 & 75 & 5 & 80 & 13 \\
\hline $\mathbf{1 9 2 9 / 1 9 3 0}$ & 331 & 28 & 359 & - & - & - & 14 \\
\hline $\mathbf{1 9 3 0 / 1 9 3 1}$ & 391 & 11 & 402 & - & - & - & 16 \\
\hline $\mathbf{1 9 3 1 / 1 9 3 2}$ & 515 & 42 & 557 & - & - & - & 15 \\
\hline $\mathbf{1 9 3 2 / 1 9 3 3}$ & 697 & 67 & 764 & - & - & - & 14 \\
\hline
\end{tabular}

143. A nagyváradi Jogi Akadémia diplomázottainak nemzetiségi megoszlása:

\begin{tabular}{|c|c|c|c|c|c|c|c|c|}
\hline \multirow{2}{*}{} & \multicolumn{7}{|c|}{ Államvizsgát tett személyek nemzetisége } \\
\cline { 2 - 8 } & \multicolumn{2}{|c|}{ Román } & \multicolumn{2}{c|}{ Magyar } & \multicolumn{2}{c|}{ Zsidó } & \multirow{2}{*}{ Egyéb } & \multirow{2}{*}{ Összesen } \\
\cline { 2 - 8 } & & $\mathbf{\%}$ & & $\mathbf{\%}$ & & $\%$ & & \\
\hline $\mathbf{1 9 2 1 / 1 9 2 2}$ & 11 & 91,7 & - & - & - & - & 1 & 12 \\
\hline $\mathbf{1 9 2 2 / 1 9 2 3}$ & 7 & 87,5 & - & - & 1 & 12,5 & - & 8 \\
\hline $\mathbf{1 9 2 3 / 1 9 2 4}$ & 36 & 85,7 & - & - & 3 & 7,1 & 3 & 42 \\
\hline $\mathbf{1 9 2 5 / 1 9 2 6}$ & 29 & 93,5 & 1 & 3,2 & 1 & 3,2 & - & 31 \\
\hline $\mathbf{1 9 2 6 / 1 9 2 7}$ & 40 & 81,6 & 3 & 6,1 & 6 & 12,2 & - & 49 \\
\hline $\mathbf{1 9 2 7 / 1 9 2 8}$ & 33 & 76,7 & 5 & 11,6 & 5 & 11,6 & - & 43 \\
\hline $\mathbf{1 9 2 8 / 1 9 2 9}$ & 59 & 73,8 & 8 & 10,0 & 13 & 16,3 & - & 80 \\
\hline
\end{tabular}

A diákok etnikai és vallási megoszlásáról az 1921-1928 közötti tanévekből rendelkezünk adatokkal. Az első világháborút megelőzően a diákok túlnyomó többsége magyar nemzetiségü volt. A magyar diákok 1918-at követően egyre nagyobb arányban maradtak távol (nyelvi nehézségek, más továbbtanulási lehetőségek választása), amelynek következtében a beiratkozott román hallgatók aránya 1924-re 73,8\%-ra növekedett. Igen magas volt a zsidó diákok aránya (16,4-27,8\% között), amely a zsidóság foglalkozásszerkezetére és pályaorientációjára ebben a korban jellemző irányokat követte. Ugyanezeket a sajátosságokat tapasztalhatjuk a felekezeti megoszlás tekintetében is. 
144. A nagyváradi Jogi Akadémia diákjainak nemzetiségi megoszlása:

\begin{tabular}{|c|c|c|c|c|c|c|c|c|c|c|}
\hline & \multicolumn{10}{|c|}{ Beiratkozott diákok nemzetisége } \\
\hline & \multicolumn{2}{|c|}{ Román } & \multicolumn{2}{|c|}{ Német } & \multicolumn{2}{|c|}{ Magyar } & \multicolumn{2}{|c|}{ Zsidó } & \multirow{2}{*}{ Egyéb } & \multirow{2}{*}{ Összesen } \\
\hline & & $\%$ & & $\%$ & & $\%$ & & $\%$ & & \\
\hline $1921 / 1922$ & 192 & 50,4 & & & & & 106 & 27,8 & 83 & 381 \\
\hline $1922 / 1923$ & 158 & 53,9 & & & & & 68 & 23,2 & 67 & 293 \\
\hline $1923 / 1924$ & 136 & 69,7 & & & & & 32 & 16,4 & 27 & 195 \\
\hline $1924 / 1925$ & 144 & 73,8 & & & & & 36 & 18,5 & 15 & 195 \\
\hline $1925 / 1926$ & 184 & 70,2 & 1 & 0,4 & 30 & 11,5 & 47 & 17,9 & - & 262 \\
\hline $1926 / 1927$ & 199 & 68,6 & 5 & 1,7 & 23 & 7,9 & 63 & 21,7 & - & 290 \\
\hline $1927 / 1928$ & 189 & 69,0 & 1 & 0,4 & 22 & 8,0 & 62 & 22,6 & - & 274 \\
\hline $1928 / 1929$ & 199 & 64,0 & 4 & 1,3 & 35 & 11,3 & 73 & 23,5 & - & 311 \\
\hline
\end{tabular}

145. A nagyváradi Jogi Akadémia diákjainak felekezeti megoszlása:

\begin{tabular}{|c|c|c|c|c|c|c|c|c|c|}
\hline & \multicolumn{9}{|c|}{ Beiratkozott diákok vallása } \\
\hline & 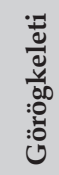 & 足 & 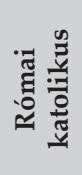 & 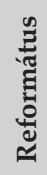 & & 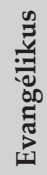 & 莺 & 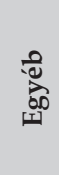 & 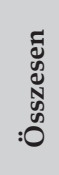 \\
\hline $1921 / 1922$ & 88 & & & & & & 106 & 187 & 381 \\
\hline $1922 / 1923$ & 76 & & & & & & 68 & 149 & 293 \\
\hline $1923 / 1924$ & 73 & & & & & & 32 & 90 & 195 \\
\hline $1924 / 1925$ & 92 & & & & & & 36 & 67 & 195 \\
\hline $1925 / 1926$ & 112 & 72 & 12 & 17 & 1 & 1 & 47 & - & 262 \\
\hline $1926 / 1927$ & 124 & 74 & 10 & 16 & 1 & 2 & 63 & - & 290 \\
\hline $1927 / 1928$ & 123 & 66 & 8 & 14 & 1 & - & 62 & - & 274 \\
\hline $1928 / 1929$ & 132 & 67 & 20 & 16 & - & 3 & 73 & - & 311 \\
\hline
\end{tabular}

146. A nagyváradi Jogi Akadémia diákjainak felekezeti megoszlása, százalékban kifejezve:

\begin{tabular}{|c|c|c|c|c|c|c|c|}
\hline & \multicolumn{7}{|c|}{ Beiratkozott diákok vallása } \\
\hline & 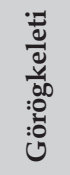 & 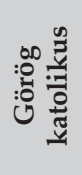 & 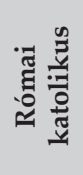 & 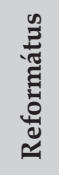 & 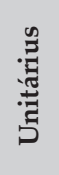 & 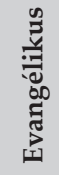 & \\
\hline $1921 / 1922$ & 23,1 & & & & & & 27,8 \\
\hline $1922 / 1923$ & 25,9 & & & & & & 23,2 \\
\hline 1923/1924 & 37,4 & & & & & & 16,4 \\
\hline $1924 / 1925$ & 47,2 & & & & & & 18,5 \\
\hline $1925 / 1926$ & 42,7 & 27,5 & 4,6 & 6,5 & 0,4 & 0,4 & 17,9 \\
\hline $1926 / 1927$ & 42,8 & 25,5 & 3,4 & 5,5 & 0,3 & 0,7 & 21,7 \\
\hline $1927 / 1928$ & 44,9 & 24,1 & 2,9 & 5,1 & 0,4 & - & 22,6 \\
\hline 1928/1929 & 42,4 & 21,5 & 6,4 & 5,1 & - & 1,0 & 23,5 \\
\hline
\end{tabular}




\subsection{Egyetemi fokú teológiai intézetek}

A különböző erdélyi egyházak teológusképzését, megfelelő források hiányában, csak töredékesen tudjuk rekonstruálni. Így például alig áll rendelkezésünkre adat a második és harmadik legnagyobb felekezet, a római katolikus és a görög katolikus teológiák/szemináriumok hallgatóiról. De ugyanígy a görögkeleti egyház esetében is csak részleges információval rendelkezünk.

1948-ig a római katolikus egyháznak három papnevelő intézete, szemináriuma volt Erdélyben: Temesváron, Szatmárnémetiben és Gyulafehérváron. Ebből az 1948-as tanügyi reformot követően csak egy, a gyulafehérvári múködhetett tovább. A temesvári teológián az 1929/1930-as tanévben 37 lelkészjelölt tanult, a szatmárnémeti papnevelő intézetben 1928/1929-ben pedig 24 (Sulyok-Fritz 1930: 42-45).

Görög katolikus teológiák Nagyváradon, Balázsfalván és Szamosújváron müködtek. Balázsfalván 1754-től képeztek görög katolikus papokat. A szamosújvári teológia 1859-től, a nagyváradi akadémia pedig 1923-tól állt fenn. Ezek közül a szamosújvári és a balázsfalvi diáklétszámokat ismerjük az 1918-1928 közötti időszakra vonatkozóan (Transilvania, Banatul, Crişana 1929: 979-982):

147. A szamosújvári és a balázsfalvi görög katolikus teológiák diákjainak száma:

\begin{tabular}{|c|c|c|}
\hline & Szamosújvár & Balázsfalva \\
\hline $\mathbf{1 9 1 8 / 1 9 1 9}$ & 12 & 7 \\
\hline $\mathbf{1 9 1 9 / 1 9 2 0}$ & 10 & 10 \\
\hline $\mathbf{1 9 2 0 / 1 9 2 1}$ & 8 & 12 \\
\hline $\mathbf{1 9 2 1 / 1 9 2 2}$ & 15 & 9 \\
\hline $\mathbf{1 9 2 2 / 1 9 2 3}$ & 14 & 18 \\
\hline $\mathbf{1 9 2 3 / 1 9 2 4}$ & 8 & 16 \\
\hline $\mathbf{1 9 2 4 / 1 9 2 5}$ & 16 & 22 \\
\hline $\mathbf{1 9 2 5 / 1 9 2 6}$ & 37 & 20 \\
\hline $\mathbf{1 9 2 6 / 1 9 2 7}$ & 19 & 25 \\
\hline $\mathbf{1 9 2 7 / 1 9 2 8}$ & 27 & 23 \\
\hline
\end{tabular}

1948. december 1-jén a román görög katolikus egyházat a kormány 358. sz. rendelete felszámolta, ezzel pedig megszűnt a teológus-utánképzés is.

A görögkeleti/ortodox papokat képző teológiák ugyancsak nagy múltra tekintenek vissza. 1811-ben Nagyszebenben hat hónapos képzést biztosító teológiai szeminárium nyílt, 1822-ben Aradon és Versecen indultak szemináriumok a bánsági és az Arad környéki papok képzésére. Görögkeleti/ortodox teológiai akadémiák csak az első világháború után jöttek létre: 
1924-ben a nagyszebeni szeminárium alakult át akadémiává, ezt követően hasonló intézmények kezdték meg müködésüket Nagyváradon, Kolozsváron és Karánsebesen. Az akadémiákra érettségizett diákok iratkozhattak be (Transilvania, Banatul, Crişana 1929: 973-975). Az alábbiakban a kolozsvári ortodox teológiai akadémia diáklétszámának alakulását közöljük (Anuarul 1930: 56, Anuarul 1937: 158, Anuar 1938: 96, Anuar 1939: 151, Moraru 1996: 94-102):

148. A kolozsvári Ortodox Teológiai Akadémia diákjainak száma:

\begin{tabular}{|c|c|}
\hline & Beiratkozott diákok \\
\hline $\mathbf{1 9 2 4 / 1 9 2 5}$ & 64 \\
\hline $\mathbf{1 9 2 5 / 1 9 2 6}$ & 72 \\
\hline $\mathbf{1 9 2 6 / 1 9 2 7}$ & 59 \\
\hline $\mathbf{1 9 2 7 / 1 9 2 8}$ & 82 \\
\hline $\mathbf{1 9 2 8 / 1 9 2 9}$ & 106 \\
\hline $\mathbf{1 9 2 9 / 1 9 3 0}$ & 112 \\
\hline $\mathbf{1 9 3 4 / 1 9 3 5}$ & 80 \\
\hline $\mathbf{1 9 3 5 / 1 9 3 6}$ & 81 \\
\hline $\mathbf{1 9 3 6 / 1 9 3 7}$ & 56 \\
\hline $\mathbf{1 9 3 7 / 1 9 3 8}$ & 53 \\
\hline $\mathbf{1 9 3 8 / 1 9 3 9}$ & 53 \\
\hline $\mathbf{1 9 3 9 / 1 9 4 0}$ & 58 \\
\hline $\mathbf{1 9 4 1 / 1 9 4 2}$ & 54 \\
\hline $\mathbf{1 9 4 2 / 1 9 4 3}$ & 64 \\
\hline $1943 / 1944$ & 63 \\
\hline $\mathbf{1 9 4 5 / 1 9 4 6}$ & 76 \\
\hline
\end{tabular}

A református és unitárius lelkészképzést a két egyház kolozsvári teológiái látták el. A diákok létszámának alakulásáról szinte teljes statisztikával rendelkezünk (Az Erdélyi Református Egyházkerület Theologiai Fakultásának Értesítője 1923-1943, A Magyarországi Unitárius Egyház 1919, A Magyar Unitárius Egyház 1921-1935, Az Unitárius Egyház 1936-1942):

149. A kolozsvári Református Teológia, valamint az Unitárius Teológia diákjainak száma:

\begin{tabular}{|c|c|c|}
\hline & Református Teológia & Unitárius Teológia \\
\hline $\mathbf{1 9 1 8 / 1 9 1 9}$ & $?$ & 5 \\
\hline $\mathbf{1 9 1 9 / 1 9 2 0}$ & $?$ & 11 \\
\hline $\mathbf{1 9 2 0 / 1 9 2 1}$ & $?$ & 21 \\
\hline $\mathbf{1 9 2 1 / 1 9 2 2}$ & 82 & $?$ \\
\hline $\mathbf{1 9 2 2 / 1 9 2 3}$ & 118 & 29 \\
\hline $\mathbf{1 9 2 3 / 1 9 2 4}$ & 126 & 29 \\
\hline $\mathbf{1 9 2 4 / 1 9 2 5}$ & 143 & 28 \\
\hline
\end{tabular}




\begin{tabular}{|c|c|c|}
\hline $1925 / 1926$ & 159 & 27 \\
\hline $1926 / 1927$ & 143 & $?$ \\
\hline $1927 / 1928$ & 172 & 29 \\
\hline $1928 / 1929$ & 183 & 33 \\
\hline $1929 / 1930$ & 188 & 27 \\
\hline $1930 / 1931$ & 191 & 35 \\
\hline $1931 / 1932$ & $?$ & 26 \\
\hline $1932 / 1933$ & $?$ & $?$ \\
\hline $1933 / 1934$ & 135 & 33 \\
\hline $1934 / 1935$ & $?$ & 28 \\
\hline $1935 / 1936$ & 117 & 28 \\
\hline $1936 / 1937$ & 129 & 30 \\
\hline $1937 / 1938$ & 148 & 29 \\
\hline $1938 / 1939$ & 149 & 23 \\
\hline $1939 / 1940$ & 152 & 20 \\
\hline $1940 / 1941$ & 94 & 15 \\
\hline $1941 / 1942$ & 70 & $?$ \\
\hline $1942 / 1943$ & 65 & \\
\hline
\end{tabular}

A második világháborút követő évekig külön teológiai intézeteket müködtető erdélyi protestáns egyházak az 1948. évi 177. sz. kultusztörvénynek és a diktatorikus államberendezkedésnek kényszere alatt közös teológiát állítottak fel. Így jött létre 1949-ben a kolozsvári Egyetemi Fokú Protestáns Teológiai Intézet, amely református, ágostai hitvallású evangélikus, zsinatpresbiteri evangélikus és unitárius növendékeket képzett a papi hivatásra. 1948/1949-ben az egyesített protestáns teológián 171 növendék tanult, a következő évben pedig 187 (Egyetemi Fokú Protestáns Theologiai Intézet 1951: 13-37).

150. A kolozsvári Egyetemi Fokú Protestáns Teológiai Intézet diákjainak száma:

\begin{tabular}{|c|c|c|c|c|}
\hline & Református & Evangélikus & Unitárius & Összesen \\
\hline $\mathbf{1 9 4 8 / 1 9 4 9}$ & 137 & 10 & 24 & 171 \\
\hline $\mathbf{1 9 4 9 / 1 9 5 0}$ & 144 & 14 & 29 & 187 \\
\hline $\mathbf{1 9 5 0 / 1 9 5 1}$ & 138 & 32 & 23 & 193 \\
\hline
\end{tabular}





\section{A KOLOZSVÁRI EGYETEM}

Az általunk vizsgált korszakban, de azt megelőzően és azt követően is a kolozsvári egyetem volt Erdély legfontosabb felsőoktatási intézménye, ezért részletesebben kívánunk foglalkozni vele.

Az 1872-ben alapított kolozsvári Ferenc József Tudományegyetemet 1919-ben a román állam vette át. Az új, román állami intézmény neve $I$. Ferdinánd Tudományegyetem lett. Az intézmény magyar tanári karának többsége elmenekült Kolozsvárról, az elűzött magyar egyetem pedig Szegeden folytatta tovább a tevékenységét 1940-ig. Az I. Ferdinánd Tudományegyetem 1919. november 3-án nyitotta meg a kapuit több mint 2000 beiratkozott diákkal. A második bécsi döntéstől 1944-ig az intézmény újból magyar egyetemként múködött. Ez alatt az időszak alatt az 1940 őszén Kolozsvárról elmenekült I. Ferdinánd Tudományegyetem Nagyszebenben folytatta a tevékenységét. A második világháborút követően a folytonosságot két különálló egyetem biztosította Kolozsváron. A Bolyai Egyetem 1945-től magyar nyelven, míg a Babeş Egyetem (amely az 1945-ben Nagyszebenből visszatérő I. Ferdinánd Tudományegyetemnek volt a jogutódja) román nyelven oktatott. ${ }^{23} \mathrm{~A}$ két intézmény önállósága 1959-ben szünt meg, amikor a román államhatalom erőszakosan egyesítette őket Babeş-Bolyai Tudományegyetem néven. ${ }^{24}$

A kolozsvári egyetemre 1912/1913-ban több mint 2300 diák iratkozott be (Karady-Nastasă 2004: 45). Az első világháború után az első években növekvő, majd egy rövid időre csökkenő tendenciát mutatott a hallgatók számának alakulása. A csúcspontot az 1930-as évek első felében érte

\footnotetext{
${ }^{23}$ A Babeş Egyetem történetére lásd: Nicoară 2010.

${ }^{24} \mathrm{Az}$ egyetem történetét és működésének körülményeit nem kívánjuk részletezni, erre nézve bőséges szakirodalom áll rendelkezésre. Gaal 2001, Pálfy 2004, Uő. 2008, Karady-Nastasă 2004, B. Kovács 1997, Barabás-Joó 1990, Puşcaş 1999, Lázok-Vincze 1998.
} 
el a létszám, ezt követően viszont ismét visszaesés tapasztalható. 1934-től ugyanis az egyetemi pálya túlzsúfoltságát enyhítendő, bevezették az egyetemi felvételi rendszert. Ennek következtében létszámcsökkenés állt be a kolozsvári egyetem diákságában. Az is megfigyelhető, hogy ez a fajta korlátozás, mivel összekapcsolódott az ún. numerus vallachicus mozgalommal, erőteljesebben érintette a kisebbségi diákokatés a nőhallgatókat (Pálfy 2004: 169-172). Mindezt figyelembe véve, 1941/1942-re még nagyobb visszaesés tapasztalható. Ez annak tulajdonítható, hogy a háborús körülmények negatív hatásai mellett a Kolozsvárról Nagyszebenbe menekült román egyetem populációjának rekrutációs területe Észak-Erdély Magyarországhoz történő visszacsatolásával jelentősen beszűkült.

Kétségkívül, a korszak pályaválasztási stratégiáinak megfelelően, a diákok többsége a Jogi- és az Orvosi Karon tanult. 1921/1922-ben például a hallgatóknak 45,4\%-a a Jogi Karra iratkozott be. A következő évben ez az arány 43,6\%, 1935/1936-ban viszont 48,1\% volt (lásd a 24-25. sz. mellékleteket).

Ami a diákok nemi megoszlását illeti, a két világháború között fokozatos kiegyenlítódési tendencia figyelhető meg. 1921/1922-ben a hallgatóknak 11,8\%-át tették ki a nők. A következő évben 14,7\%-ot alkottak, majd 1925-től húsz százalék fölé emelkedett az arányuk. A legtöbb diáklány az 1931/1932-es tanévre iratkozott be. Ekkor 24,3\%-ot alkottak. Az 1930-as évek közepére az egyetemre beiratkozott lányok aránya megközelítette az érettségit adó iskolák lánydiákjaiét. Az 1928/1929-es tanévben például, a II. fokú leány-középiskolákban és felsőkereskedelmi iskolákban $25,3 \%$ volt az arányuk, a kolozsvári egyetemen pedig 20-24\%.

Sem a tanárok, sem a diákok száma nem nőtt jelentősen a két világháború között. Az 1921/1922-es tanévhez képest 1938/1939-ben csupán 17,1\%-kal tanult több hallgató az egyetemen, és a tanárok száma is csak 14,2\%-kal emelkedett. Mindez azért meglepő, mert amint korábban jeleztük, ebben az időszakban jelentős fejlesztések mentek végbe a romániai középiskolai rendszerben, tehát elméletileg egyre több, egyetemi felvételire jogot formálható tanuló került ki a líceumok padjaiból. A magyarázat valószínűleg több okban kereshető.

Az egyik okra, a kisebbségi diákok távolmaradására már utaltunk. Egy másik ok viszont az érettségiző diákok alacsony száma. Országos szinten az érettségire jelentkező diákoknak megközelítőleg fele szerzett érettségi bizonyítványt. Így 1925-ben például 40,4\%-os, 1929-ben 51,8\%-os, 1932-ben kivételes módon 74,1\%-os, 1935-ben viszont csak 31,7\%-os volt a sikeresen érettségizők aránya (Angelescu 1939: 34). 
A harmadik ok a bukaresti egyetem erős vonzóerejében rejtőzhet. Bukarest ugyanis, fővárosi jellegéből adódóan, jelentős vidéki diáksereget vonzott, és ennek köszönhetően az ország legnagyobb egyetemi központja volt. 1926/1927-ben például a romániai egyetemisták 65,8\%-a tanult a bukaresti egyetemen, míg a kolozsvárin csak 11,3\% (Pálfy 2004: 165).

Az alábbiakban évekre lebontva közöljük az egyetem hallgatói és tanárai számának alakulását (Az egyes karokra beiratkozott diákokra vonatkozó adatokat lásd a 24-25. sz. mellékletekben).

151. A kolozsvári I. Ferdinánd Tudományegyetem diákjainak nemi megoszlása és a tanári kar:

\begin{tabular}{|l|c|c|c|c|c|}
\hline \multirow{2}{*}{} & \multirow{2}{*}{ Férfi } & \multicolumn{2}{|c|}{ Nö } & \multirow{2}{*}{ Összesen } & \multirow{2}{*}{ Tanári kar } \\
\cline { 3 - 4 } & & & $\mathbf{\%}$ & & \\
\hline $\mathbf{1 9 2 1 / 1 9 2 2}$ & 2330 & 313 & 11,8 & 2643 & 296 \\
\hline $\mathbf{1 9 2 2 / 1 9 2 3}$ & 2474 & 426 & 14,7 & 2900 & 293 \\
\hline $\mathbf{1 9 2 3 / 1 9 2 4}$ & 1712 & 304 & 15,1 & 2016 & 318 \\
\hline $\mathbf{1 9 2 4 / 1 9 2 5}$ & 1722 & 390 & 18,5 & 2112 & 316 \\
\hline $\mathbf{1 9 2 5 / 1 9 2 6}$ & 1810 & 482 & 21,0 & 2292 & 325 \\
\hline $\mathbf{1 9 2 6 / 1 9 2 7}$ & 2004 & 545 & 21,4 & 2549 & 324 \\
\hline $\mathbf{1 9 2 7 / 1 9 2 8}$ & 2090 & 622 & 22,9 & 2712 & 346 \\
\hline $\mathbf{1 9 2 8 / 1 9 2 9}$ & 2326 & 730 & 23,9 & 3056 & 347 \\
\hline $\mathbf{1 9 2 9 / 1 9 3 0}$ & 2866 & 827 & 22,4 & 3693 & 349 \\
\hline $\mathbf{1 9 3 0 / 1 9 3 1}$ & 3085 & 979 & 24,1 & 4064 & 370 \\
\hline $\mathbf{1 9 3 1 / 1 9 3 2}$ & 3121 & 1003 & 24,3 & 4124 & 374 \\
\hline $\mathbf{1 9 3 2 / 1 9 3 3}$ & 3442 & 1027 & 23,0 & 4469 & 344 \\
\hline $\mathbf{1 9 3 3 / 1 9 3 4}$ & 3370 & 1075 & 24,2 & 4445 & $?$ \\
\hline $\mathbf{1 9 3 4} / \mathbf{1 9 3 5}$ & 3449 & 851 & 19,8 & 4300 & $?$ \\
\hline $\mathbf{1 9 3 5 / 1 9 3 6}$ & 2861 & 712 & 19,9 & 3573 & 321 \\
\hline $\mathbf{1 9 3 6 / 1 9 3 7}$ & 2551 & 688 & 21,2 & 3239 & 338 \\
\hline $\mathbf{1 9 3 7 / 1 9 3 8}$ & 2483 & 672 & 21,3 & 3155 & $?$ \\
\hline $\mathbf{1 9 3 8} / \mathbf{1 9 3 9}$ & 2466 & 628 & 20,3 & 3094 & $?$ \\
\hline $\mathbf{1 9 4 1 / 1 9 4 2}$ & 1689 & 519 & 23,5 & 2208 & $?$ \\
\hline
\end{tabular}

Az államvizsgát tett vagy doktori címet szerzett hallgatók számáról az 1920-as évekre nézve rendelkezünk teljes adatsorokkal. Az 1930-as évekből néhány esetben csak a férfiak és nők összesített adatait ismerjük. 1921/1922 és 1928/1929 között 765 diák államvizsgázott, közülük 236 (30,8\%) volt nő. A doktorátust szerzettek száma 1488 volt (94, azaz 6,3\% nő). A következő évtizedben, 1930/1931-1934/1935 és 1937/1938-1938/1939 között, valamint 1941/1942-ben az államvizsgázók száma összesen 2169, a doktori diplomát megszerzőké pedig 1849 volt. 
152. Az I. Ferdinánd Tudományegyetemen államvizsgát és doktorátust szerzett diákok száma:

\begin{tabular}{|c|c|c|}
\hline & Államvizsgát tettek & Doktorok \\
\hline $\mathbf{1 9 2 1} / \mathbf{1 9 2 2}$ & 39 & 255 \\
\hline $\mathbf{1 9 2 2} / \mathbf{1 9 2 3}$ & 28 & 227 \\
\hline $\mathbf{1 9 2 3 / 1 9 2 4}$ & 34 & 235 \\
\hline $\mathbf{1 9 2 4} / \mathbf{1 9 2 5}$ & 7 & 1 \\
\hline $\mathbf{1 9 2 5} / \mathbf{1 9 2 6}$ & 249 & 205 \\
\hline $\mathbf{1 9 2 6 / 1 9 2 7}$ & 87 & 219 \\
\hline $\mathbf{1 9 2 7 / 1 9 2 8}$ & 150 & 168 \\
\hline $\mathbf{1 9 2 8} / \mathbf{1 9 2 9}$ & 171 & 178 \\
\hline $\mathbf{1 9 3 0} / \mathbf{1 9 3 1}$ & 206 & 132 \\
\hline $\mathbf{1 9 3 1} / \mathbf{1 9 3 2}$ & 228 & 200 \\
\hline $\mathbf{1 9 3 2} / \mathbf{1 9 3 3}$ & 224 & 223 \\
\hline $\mathbf{1 9 3 3} / \mathbf{1 9 3 4}$ & 221 & 276 \\
\hline $\mathbf{1 9 3 4} / \mathbf{1 9 3 5}$ & 233 & 300 \\
\hline $\mathbf{1 9 3 7 / 1 9 3 8}$ & 355 & 281 \\
\hline $\mathbf{1 9 3 8 / 1 9 3 9}$ & 469 & 323 \\
\hline $1941 / 1942$ & 233 & 114 \\
\hline
\end{tabular}

Látható, hogy az államvizsgát tett hallgatók száma 1925-öt követően ugrik meg, és folyamatosan hullámzik az évek során. A csúcspontot az 1938/1939-es tanév jelenti, amikor 469-en végzik el az egyetemet. A Nagyszebenbe menekült román egyetem 1941/1942-es adatai újabb visszaesést mutatnak. Hasonló hullámzást figyelhetünk meg a doktori címet szerzők számának alakulását illetően is (A részletes, fakultásokra lebontott kimutatást lásd a 26-27. sz. mellékletekben).

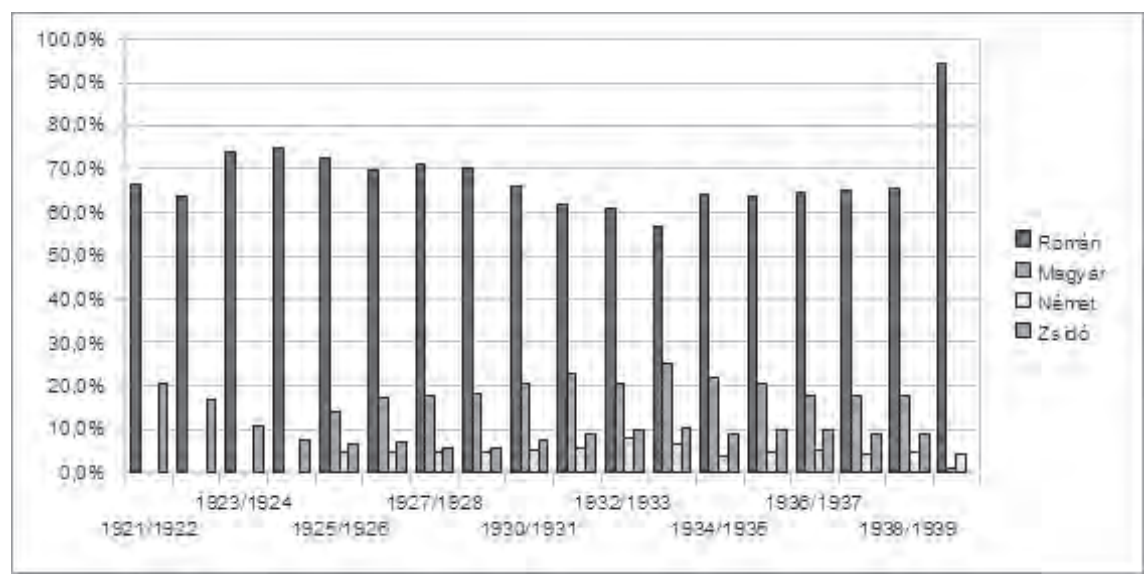


A hallgatók etnikai megoszlása az első világháborút követően jelentős változáson ment keresztül. A korábban 80\% körüli magyar fölény 1918 után megfordult a román hallgatók javára. Mindez több okra is visszavezethető. A háború után a magyar egyetem Szegedre menekült, a Kolozsváron tovább működő intézményt pedig a román állam vette át, és a tanítási nyelv a román lett. Ennek következtében a román nyelvet nem ismerő diákok számára igen nehézkessé vált tanulmányaik folytatása. Habár elméletileg nemzetiségi különbség nélkül, mindenkinek egyenlő joga volt a kolozsvári egyetemre beiratkozni és ott tanulni, az első világháború utáni évek gyakorlata azt mutatja, hogy az oktatáspolitika egyértelműen hátrányban részesítette a nemzetiségi hallgatókat (elsősorban a magyarokat és zsidókat). Egyes becslések szerint például a potenciális magyar egyetemi diákságnak a kilencven százaléka vagy Románián kívül (elsősorban Magyarországon) iratkozott be egyetemre az 1918 utáni első években, vagy egyáltalán nem tanult tovább (Pálfy 2004: 161, Livezeanu 1995: 226-227).

A fenti grafika kitűnően szemlélteti a kolozsvári egyetem hallgatói etnikai megoszlásának alakulását a két világháború között. Az 1925/1926-os tanévig csak a román és zsidó diákok számát ismerjük pontosan. Látható, hogy az első években a román diákság aránya 66,6\%-ról fokozatosan 75-ig nőtt, míg a zsidóké és az Egyéb kategóriába sorolt magyaroké és németeké csökkent. Csupán az 1925/1926-os tanévtől kezdődően tapasztalható egy enyhe növekedés a nem román etnikumú hallgatók arányában. Ebből a szempontból az 1933/1934-es év tekinthető a csúcspontnak, amikor a magyarok 25,4 százalékot tettek ki, a németek 6,4-et és a zsidók 10,3-at. Ezt követően többek között az egyetemi numerus valachicusnak tulajdoníthatóan újra fogyatkozni kezdenek a kisebbségi diákok.

Az etnikai és a felekezeti arányok ingadozásától függetlenül két állandó jellemzőre kell kitérnünk. Láttuk, hogy az érettségit adó középiskolai intézményekben a román (illetve a görögkeleti és görög katolikus) és a zsidó (izraelita) diákok felülreprezentáltak voltak, amely automatikusan azt eredményezte, hogy a többi etnikumhoz képest nagyobb potenciállal rendelkeztek az elit utánpótlás terén. A legnagyobb előnyt a román diákság élvezte a felvételiknél, a középiskolai adatokkal összehasonlítva mégis a zsidó érettségizők jutottak be nagyobb arányban. Ezt bizonyítja az is, hogy az 1928/1929-es tanévben az érettségit adó erdélyi líceumokba, II. fokú leány-középiskolákba és a felső kereskedelmi iskolákba beiratkozott tanulók között a románok 54,5\%-ot tettek ki. Négy-öt év múlva, tehát amikor az 1928/1929-es generáció eljutott az egyetemi felvételi időszakához, a kolozsvári egyetemre beiratkozott diákoknak 56,6-64,1\%-a román nemzetiségü volt. Ha a felekezeti adatokat vesszük alapul, akkor is hasonló eredményekre jutunk: az érettségit adó erdélyi középiskolákba beiratko- 
zott görögkeleti és görög katolikus diákok együttesen 54,8\%-ot alkottak, az 1933/1934-ben és 1934/1935-ben egyetemi felvételit nyert hallgatók között pedig 56,8-63,5\%-ot. A zsidók/izraeliták esetében ez a következőképpen nézett ki: 1928/1929-ben 8,9\%-ot tettek ki az érettségit adó középiskolákba beiratkozott tanulók között, 1933/1934-ben és 1934/1935-ben 9,2-10,3\%-ot a kolozsvári egyetem beiratkozottai között.

Pontos adatok hiányában csak megbecsülni tudjuk, hogy az 1933-1934 körüli időszakban mekkora volt az egyes etnikumok aránya az összes erdélyi felsőoktatási intézmény hallgatóin belül. A román diákok a kolozsvári egyetemen, a kolozsvári Elektromechanikai Almérnöki Iskolában, az Agrártudományi Akadémián, a Felsőkereskedelmi és Ipari Akadémián, a Zene- és Színmüvészeti Akadémián, valamint a temesvári Szépművészeti Iskolában, illetve a Politechnikán és a nagyváradi Jogi Akadémián összesen mintegy 62\%-ot alkothattak, a zsidók pedig 11-et (lásd a 117-153. sz. táblázatokat). Látható tehát, hogy az első világháború előtti időszakból örökölt zsidó túliskolázottság 1918 után is megmaradt, habár a zsidók arányszáma az 1930-as évekre a jelentősebb felsőfokú intézményekben csökkenést mutatott. Ezzel szemben az alsó és középfokú oktatási rendszer, valamint az egyetemi szféra romanizálásának köszönhetően a román népesség iskolázottságbeli lemaradása fokozatosan megszűnt.

Az 1940-ben Nagyszebenbe menekült kolozsvári román egyetemre szinte kizárólag csak román diákok iratkoztak be, zsidókat pedig egyáltalán nem vettek fel (Az egyes fakultások diákjainak etnikai megoszlását lásd a 28-29. sz. mellékletekben).

153. Az I. Ferdinánd Tudományegyetem diákjainak nemzetiségi megoszlása, százalékban kifejezve:

\begin{tabular}{|c|c|c|c|c|c|c|c|c|c|c|c|}
\hline & \multicolumn{2}{|c|}{ Román } & \multicolumn{2}{|c|}{ Magyar } & \multicolumn{2}{|c|}{ Német } & \multicolumn{2}{|c|}{ Zsidó } & \multicolumn{2}{|c|}{ Egyéb } & \multirow{2}{*}{ Összesen } \\
\hline & & $\%$ & & $\%$ & & $\%$ & & $\%$ & & $\%$ & \\
\hline 1921/1922 & 1759 & 66,6 & & & & & 539 & 20,4 & 345 & 13,1 & 2643 \\
\hline $1922 / 1923$ & 1842 & 63,5 & & & & & 494 & 17,0 & 564 & 19,4 & 2900 \\
\hline $1923 / 1924$ & 1495 & 74,2 & & & & & 223 & 11,1 & 298 & 14,8 & 2016 \\
\hline $1924 / 1925$ & 1583 & 75,0 & & & & & 155 & 7,3 & 374 & 17,7 & 2112 \\
\hline $1925 / 1926$ & 1672 & 72,9 & 321 & 14,0 & 114 & 5,0 & 151 & 6,6 & 34 & 1,5 & 2292 \\
\hline $1926 / 1927$ & 1772 & 69,5 & 447 & 17,5 & 121 & 4,7 & 179 & 7,0 & 30 & 1,2 & 2549 \\
\hline $1927 / 1928$ & 1923 & 70,9 & 488 & 18,0 & 127 & 4,7 & 153 & 5,6 & 21 & 0,8 & 2712 \\
\hline $1928 / 1929$ & 2140 & 70,0 & 567 & 18,6 & 143 & 4,7 & 173 & 5,7 & 33 & 1,1 & 3056 \\
\hline $1930 / 1931$ & 2685 & 66,1 & 842 & 20,7 & 207 & 5,1 & 301 & 7,4 & - & - & 4064 \\
\hline $1931 / 1932$ & 2540 & 61,6 & 935 & 22,7 & 231 & 5,6 & 388 & 9,4 & - & - & 4124 \\
\hline $1932 / 1933$ & 2722 & 60,9 & 922 & 20,6 & 345 & 7,7 & 447 & 10,0 & - & - & 4469 \\
\hline $1933 / 1934$ & 2518 & 56,6 & 1127 & 25,4 & 284 & 6,4 & 456 & 10,3 & - & - & 4445 \\
\hline 1934/1935 & 2757 & 64,1 & 945 & 22,0 & 177 & 4,1 & 396 & 9,2 & - & - & 4300 \\
\hline
\end{tabular}




\begin{tabular}{|c|c|c|c|c|c|c|c|c|c|c|c|}
\hline $\mathbf{1 9 3 5 / 1 9 3 6}$ & 2273 & 63,6 & 733 & 20,5 & 163 & 4,6 & 353 & 9,9 & 8 & 0,2 & 3573 \\
\hline $\mathbf{1 9 3 6 / 1 9 3 7}$ & 2101 & 64,9 & 580 & 17,9 & 167 & 5,2 & 321 & 9,9 & 34 & 1,0 & 3239 \\
\hline $\mathbf{1 9 3 7 / 1 9 3 8}$ & 2059 & 65,3 & 566 & 17,9 & 132 & 4,2 & 296 & 9,4 & - & - & 3155 \\
\hline $\mathbf{1 9 3 8 / 1 9 3 9}$ & 2029 & 65,6 & 553 & 17,9 & 147 & 4,8 & 286 & 9,2 & - & - & 3094 \\
\hline $\mathbf{1 9 4 1 / 1 9 4 2}$ & 2080 & 94,2 & 18 & 0,8 & 100 & 4,5 & - & - & - & - & 2208 \\
\hline
\end{tabular}

A felekezeti megoszlásra nézve, hasonlóan az etnikai kimutatásokhoz, csak 1925-től rendelkezünk teljes adatsorokkal. Az 1920-as évek elejéről csak a görögkeleti (ortodox) és az izraelita hallgatók számát ismerjük. Az elsősorban magyar vagy német nemzetiségü római katolikusok, reformátusok, evangélikusok és unitáriusok számáról 1925-öt követően közölnek információkat az általunk használt források.

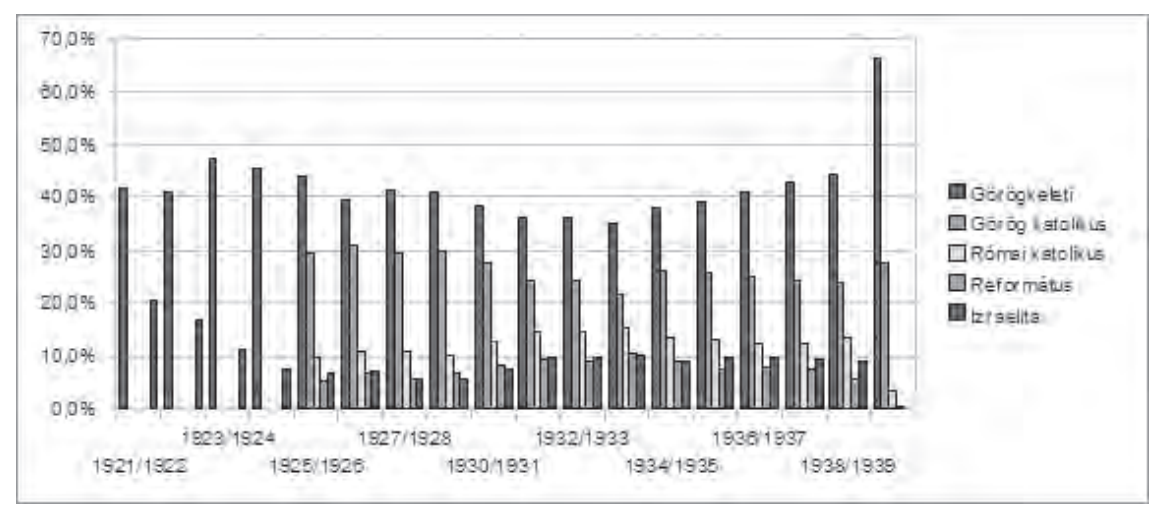

A görögkeleti vallású diákok képviselték mindvégig a legnagyobb diákkontingenst a két világháború között. A görög katolikusokkal együtt pedig 54-74 \%-ot tettek ki. A többi vallás arányának alakulása a nemzetiségi megoszlást követte. Mind az izraeliták, mind a római katolikus és a protestáns felekezetü diákok száma csökkenést mutatott az első világháború után, és csak az 1930-as évek első felében tapasztalható növekedés a körükben (Az egyes felekezetek karonkénti megoszlását lásd a 30-33. sz. mellékletekben).

A kezdeti évek legnagyobb visszaesése az izraelita diákok körében történt. 1921-hez viszonyítva 1923-ban 58,6\%-kal kevesebb zsidó iratkozott be az egyetemre. Ennek egyik oka a felerösödő egyetemi antiszemitizmusban kereshető. 1920-tól kezdődően egyre több zsidóellenes akciót hajtott végre a román egyetemi diákság. Ennek egyik csúcspontja 1922 márciusában és október-novemberében volt, amikor az Orvosi Kar diákjai numerus clausus bevezetését követelték, és megakadályozták a zsidó diákok részvételét a tanórákon, valamint zsidó érdekeltségű üzleteket, szerkesztőségeket 
támadtak meg Kolozsváron (Gidó 2006: 41). A másik ok kétségtelenül a nyelvismeret hiányában kereshető. Ugyanúgy, ahogy a többi magyar anyanyelvű egyetemi hallgató számára, a magyar kultúrájú zsidóság számára is gondot jelentett a román nyelven történő tanulás, és ezért sokan Magyarországra vagy egyéb külföldi egyetemre mentek tanulni.

Miután a kolozsvári román egyetem 1940-ben Nagyszebenbe menekült, a felekezeti arányok még inkább a görögkeletiek és a görög katolikusok javára mozdultak el. Izraelitákat ekkor már egyáltalán nem találunk a diákok között.

154. A kolozsvári I. Ferdinánd Tudományegyetemre beiratkozott diákok felekezeti megoszlása:

\begin{tabular}{|c|c|c|c|c|c|c|c|c|c|}
\hline & 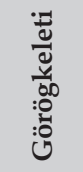 & 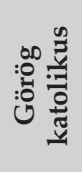 & 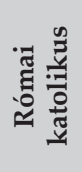 & 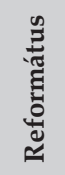 & 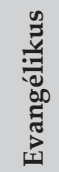 & & 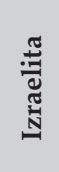 & 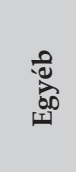 & $\begin{array}{l}\text { हี } \\
\text { \& } \\
\text { N } \\
: 0\end{array}$ \\
\hline 1921/1922 & 1109 & & & & & & 539 & 995 & 2643 \\
\hline $1922 / 1923$ & 1182 & & & & & & 494 & 1224 & 2900 \\
\hline $1923 / 1924$ & 951 & & & & & & 223 & 842 & 2016 \\
\hline $1924 / 1925$ & 961 & & & & & & 155 & 996 & 2112 \\
\hline $1925 / 1926$ & 1011 & 674 & 225 & 119 & 86 & 25 & 151 & 1 & 2292 \\
\hline $1926 / 1927$ & 1003 & 793 & 280 & 169 & 98 & 25 & 179 & 2 & 2549 \\
\hline $1927 / 1928$ & 1132 & 804 & 293 & 157 & 121 & 51 & 153 & 1 & 2712 \\
\hline $1928 / 1929$ & 1244 & 914 & 316 & 204 & 132 & 71 & 173 & 2 & 3056 \\
\hline $1930 / 1931$ & 1566 & 1116 & 519 & 330 & 180 & 48 & 302 & 3 & 4064 \\
\hline $1931 / 1932$ & 1495 & 1004 & 599 & 397 & 167 & 54 & 404 & 4 & 4124 \\
\hline $1932 / 1933$ & 1624 & 1087 & 638 & 405 & 196 & 65 & 446 & 8 & 4469 \\
\hline $1933 / 1934$ & 1559 & 967 & 688 & 473 & 221 & 74 & 453 & 10 & 4445 \\
\hline $1934 / 1935$ & 1631 & 1116 & 572 & 378 & 141 & 59 & 396 & 7 & 4300 \\
\hline $1935 / 1936$ & 1390 & 914 & 461 & 261 & 142 & 50 & 353 & 2 & 3573 \\
\hline $1936 / 1937$ & 1322 & 810 & 395 & 248 & 98 & 41 & 321 & 4 & 3239 \\
\hline $1937 / 1938$ & 1358 & 765 & 393 & 233 & 68 & 36 & 296 & 6 & 3155 \\
\hline $1938 / 1939$ & 1367 & 736 & 418 & 173 & 79 & 36 & 284 & 1 & 3094 \\
\hline $1941 / 1942$ & 1470 & 608 & 81 & 11 & 35 & - & - & 3 & 2208 \\
\hline
\end{tabular}


155. A kolozsvári I. Ferdinánd Tudományegyetemre beiratkozott diákok felekezeti megoszlása, százalékban kifejezve:

\begin{tabular}{|c|c|c|c|c|c|c|c|c|}
\hline & 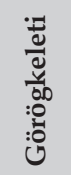 & 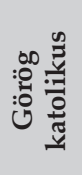 & 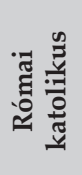 & 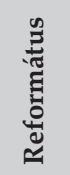 & 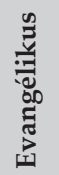 & 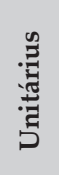 & 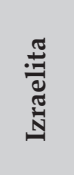 & $\overbrace{010}^{00}$ \\
\hline $1921 / 1922$ & 42,0 & & & & & & 20,4 & 37,6 \\
\hline $1922 / 1923$ & 40,8 & & & & & & 17,0 & 42,2 \\
\hline $1923 / 1924$ & 47,2 & & & & & & 11,1 & 41,8 \\
\hline $1924 / 1925$ & 45,5 & & & & & & 7,3 & 47,2 \\
\hline $1925 / 1926$ & 44,1 & 29,4 & 9,8 & 5,2 & 3,8 & 1,1 & 6,6 & - \\
\hline $1926 / 1927$ & 39,3 & 31,1 & 11,0 & 6,6 & 3,8 & 1,0 & 7,0 & 0,1 \\
\hline $1927 / 1928$ & 41,7 & 29,6 & 10,8 & 5,8 & 4,5 & 1,9 & 5,6 & - \\
\hline $1928 / 1929$ & 40,7 & 29,9 & 10,3 & 6,7 & 4,3 & 2,3 & 5,7 & 0,1 \\
\hline $1930 / 1931$ & 38,5 & 27,5 & 12,8 & 8,1 & 4,4 & 1,2 & 7,4 & 0,1 \\
\hline 1931/1932 & 36,3 & 24,3 & 14,5 & 9,6 & 4,0 & 1,3 & 9,8 & 0,1 \\
\hline $1932 / 1933$ & 36,3 & 24,3 & 14,3 & 9,1 & 4,4 & 1,5 & 10,0 & 0,2 \\
\hline $1933 / 1934$ & 35,1 & 21,8 & 15,5 & 10,6 & 5,0 & 1,7 & 10,2 & 0,2 \\
\hline $1934 / 1935$ & 37,9 & 26,0 & 13,3 & 8,8 & 3,3 & 1,4 & 9,2 & 0,2 \\
\hline $1935 / 1936$ & 38,9 & 25,6 & 12,9 & 7,3 & 4,0 & 1,4 & 9,9 & 0,1 \\
\hline $1936 / 1937$ & 40,8 & 25,0 & 12,2 & 7,7 & 3,0 & 1,3 & 9,9 & 0,1 \\
\hline $1937 / 1938$ & 43,0 & 24,2 & 12,5 & 7,4 & 2,2 & 1,1 & 9,4 & 0,2 \\
\hline $1938 / 1939$ & 44,2 & 23,8 & 13,5 & 5,6 & 2,6 & 1,2 & 9,2 & - \\
\hline $1941 / 1942$ & 66,6 & 27,5 & 3,7 & 0,5 & 1,6 & - & - & 0,1 \\
\hline
\end{tabular}

Az 1940-ben Nagyszebenbe menekült román egyetem 1942-1944 közötti statisztikái nem álltak rendelkezésünkre. Ami a Kolozsváron ugyancsak ebben az időszakban müködő magyar egyetemet illeti, két évből, 1940/1941 és 1941/1942-ből ismerjük a hallgatók létszámát. Etnikai bontással viszont ez esetben sem rendelkezünk.

A Magyarországhoz visszakerült Kolozsvár egyetemére 1940-ben a második félévre 2334 hallgató iratkozott be. Közülük 286, azaz 12,3\% volt nő, amely lényeges visszaesést jelentett a két világháború közötti időszakhoz képest. Ugyanez az arány 1941/1942-ben 16,3\%-ra nőtt (Magyar statisztikai évkönyv 1943: 211, és 1944: 227). Összevetve a két világháború közötti román egyetem adataival a nemek közötti arányokat, jelentős csökkenés állapítható meg a nők rovására. De ugyanígy a hallgatók összlétszáma is alulmaradt a korábbi évekhez viszonyítva, hiszen Erdély két részre történő osztása következtében kevesebb diák jutott az egyetemre. 
156. A kolozsvári Ferenc József Tudományegyetem diákjainak nemi megoszlása és a tanerók száma:

\begin{tabular}{|c|c|c|c|c|c|c|c|c|}
\hline & \multirow{3}{*}{ 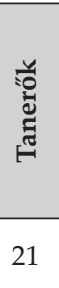 } & \multicolumn{2}{|c|}{$\begin{array}{c}\text { Hallgatók } \\
\text { száma }\end{array}$} & \multicolumn{4}{|c|}{ Hallgatók a II. féléven } \\
\hline & & & \multirow{2}{*}{$\begin{array}{l}\begin{array}{l}\text { I. } \\
\text { félév }\end{array} \\
1480\end{array}$} & \multirow{2}{*}{$\begin{array}{c}\begin{array}{c}\text { II. } \\
\text { félév }\end{array} \\
1368\end{array}$} & \multirow{2}{*}{$\begin{array}{l}\text { Férfi } \\
1340\end{array}$} & \multicolumn{2}{|c|}{ Nő } & \multirow{2}{*}{ 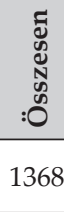 } \\
\hline \multirow{6}{*}{$1940 / 1941$} & $\begin{array}{l}\text { Jog- és Államtudományi } \\
\text { Kar }\end{array}$ & & & & & 28 & 2,0 & \\
\hline & Bölcsészkar & 29 & 202 & 200 & 101 & 99 & 49,5 & 200 \\
\hline & Természettudományi Kar & 45 & 107 & 111 & 75 & 36 & 32,4 & 111 \\
\hline & Orvostudományi Kar & 91 & 359 & 340 & 269 & 71 & 20,9 & 340 \\
\hline & $\begin{array}{l}\text { Közgazdaság-tudományi } \\
\text { Kar }\end{array}$ & 36 & 301 & 315 & 263 & 52 & 16,5 & 315 \\
\hline & Összesen & 222 & 2449 & 2334 & 2048 & 286 & 12,3 & 2334 \\
\hline \multirow{6}{*}{ 1941/1942 } & $\begin{array}{l}\text { Jog- és Államtudományi } \\
\text { Kar } \\
\end{array}$ & 25 & 1302 & 1161 & 1140 & 21 & 1,8 & 1161 \\
\hline & Bölcsészkar & 37 & 268 & 224 & 106 & 118 & 52,7 & 224 \\
\hline & Természettudományi Kar & 50 & 124 & 125 & 77 & 48 & 38,4 & 125 \\
\hline & Orvostudományi Kar & 99 & 433 & 424 & 331 & 93 & 21,9 & 424 \\
\hline & $\begin{array}{l}\text { Közgazdaság-tudományi } \\
\text { Kar }\end{array}$ & 29 & 438 & 427 & 322 & 105 & 24,6 & 427 \\
\hline & Összesen & 240 & 2565 & 2361 & 1976 & 385 & 16,3 & 2361 \\
\hline
\end{tabular}

A diákok felekezeti megoszlását az 1941/1942-es és 1942/1943-as tanévekből ismerjük (Magyar statisztikai évkönyv 1943: 227 és 1944: 243). Ezek szerint jelentős átrendeződés ment végbe a két világháború közötti viszonyokhoz képest. Lényegében ugyanaz történt, mint 1918 után, amikor is mind az etnikai, mind a felekezeti arányok teljes mértékben megfordultak. Az elsősorban román nemzetiségü görögkeletiek és görög katolikusok aránya öt-hat százalékra esett vissza, amely messze alulmaradt a két felekezet észak-erdélyi arányától. Ehhez képest 1938/1939-ben az I. Ferdinánd Tudományegyetemen hatvannyolc százalékot alkottak. Túlnyomó többségbe kerültek viszont a magyar nemzetiségü római katolikusok, reformátusok és unitáriusok. Ha ehhez még hozzáadjuk a magyar vagy német etnikumú evangélikusokat és a magyar anyanyelvű izraelitákat, akkor még szembetűnőbbé válik a különbség.

Nem követte az országos arányokat a római katolikus és református hallgatók megoszlása. Az 1941-es népszámlálás szerint Észak-Erdélyben $20,8 \%$ római katolikus és $22,9 \%$ református élt. A kolozsvári egyetemen viszont jóval több római katolikus tanult, mint református, amely valószí- 
nűleg a Szegedről áttelepített diákkontingensnek köszönhető. A második bécsi döntést követően ugyanis az 1919-ben Szegedre menekült kolozsvári Ferenc József Tudományegyetem kettévált, és egy része visszaköltözött Kolozsvárra.

Érdemes kitérni az izraelita (zsidó) diáklétszám csökkenésének okaira is. Ellentétben a román diákokkal, akiknek jelentős része Nagyszebenben tanult tovább az 1940-ben odamenekült I. Ferdinánd Tudományegyetemen, a zsidó hallgatók aránya más okok miatt szorult vissza. 1939-ben Magyarországon bevezették a második zsidótörvényt, amely a faji alapú elkülönítésen túl a zsidók arányszámát a korábbi 20-ról 6\%-ra csökkentette az értelmiségi és szabadfoglalkozású pályákon. A törvény az egyetemeken numerus clausust vezetett be, amely azt jelentette, hogy a felsőoktatási intézmények első évfolyamára csak olyan mértékben lehetett zsidónak minősülő hallgatókat felvenni, hogy azoknak aránya ne haladja meg az illető egyetem vagy főiskola karára felvett összes diákok $6 \%$-át. Kivételt képezett a budapesti József Nádor Müszaki és Gazdaságtudományi Egyetem Müszaki Kara, ahol 12\%-ban szabták meg a felvehető zsidó diákok arányát. ${ }^{25} \mathrm{~A}$ törvény szigora Kolozsvár esetében is érvényesült, ahol 1941/1942-ben 5\%, a következő tanévben pedig 3,5\% volt a zsidó hallgatók aránya.

157. A kolozsvári Ferenc József Tudományegyetem diákjainak felekezeti megoszlása:

\begin{tabular}{|c|c|c|c|c|c|c|c|c|c|}
\hline & \multicolumn{9}{|c|}{ Második félévre beiratkozott hallgatók vallása } \\
\hline & 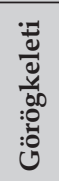 & 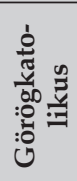 & 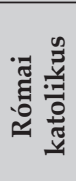 & 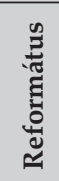 & 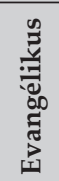 & & 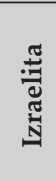 & 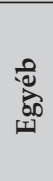 & 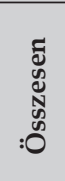 \\
\hline 1941/1942 & 16 & 114 & 1190 & 716 & 98 & 107 & 119 & 1 & 2361 \\
\hline $1942 / 1943$ & 18 & 121 & 1231 & 693 & 117 & 93 & 82 & 1 & 2356 \\
\hline
\end{tabular}

158. A kolozsvári Ferenc József Tudományegyetem diákjainak felekezeti megoszlása, százalékban kifejezve:

\begin{tabular}{|c|c|c|c|c|c|c|c|}
\hline & \multicolumn{7}{|c|}{ Második félévre beiratkozott hallgatók vallása } \\
\hline & 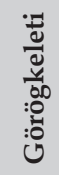 & 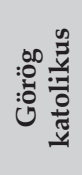 & 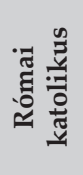 & 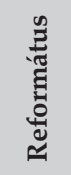 & 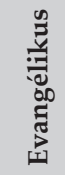 & 苞 & \\
\hline 1941/1942 & 0,7 & 4,8 & 50,4 & 30,3 & 4,2 & 4,5 & 5,0 \\
\hline $1942 / 1943$ & 0,8 & 5,1 & 52,2 & 29,4 & 5,0 & 3,9 & 3,5 \\
\hline
\end{tabular}
${ }^{25}$ A törvény szövegét lásd: http://www.1000ev.hu/index.php?a=3\&param=8098 (megtekintve
2010. október 17-én). (Vö. Gyurgyák 2001: 144-146). 
A második világháborút követően Kolozsváron két egyetem működött. A helyben maradt magyar egyetem 1946-ban a Bolyai János nevet, míg a Nagyszebenből 1945-ben visszaköltözött román egyetem 1948-ban a Victor Babeş nevet vette fel.

Az 1944/1945-ös tanév volt az egyik legzavarosabb tanítási időszak a kolozsvári magyar egyetem számára. 1944 őszén szovjet és román csapatok vonultak be Észak-Erdélybe, majd 1945 tavaszáig szovjet katonai közigazgatás alá került a terület. A zúrzavaros politikai események következtében a kolozsvári egyetem diákjainak száma nagyon megcsappant. Az 1944/1945-ös tanév második félévére mindössze 856 diák iratkozott be (Pálfy 2008: 285).

A következő évre normalizálódott a terület helyzete, amely az egyetemisták létszámában is megmutatkozott. Egyes források szerint a magyar egyetemre az 1945/1946-os tanévre 2288 diák iratkozott be, a románra pedig 6884 (Nicoară 2010: 136, 140). A román Művelődés- és Vallásügyi Minisztérium korabeli kimutatásai ettől eltérő adatokat közölnek: Az I. Ferdinánd Tudományegyetemre beiratkozottak száma 1945 őszén összesen 6683 volt, a legtöbbjük az Orvosi Karon és a Jogi Karon tanult. ${ }^{26}$

159. A kolozsvári I. Ferdinánd Tudományegyetem diákjainak és tanárainak száma 1945/1946-ban:

\begin{tabular}{|l|c|c|}
\hline & Diákok & Tanárok \\
\hline Jogi Kar & 2522 & 25 \\
\hline Bölcsészkar & 728 & 87 \\
\hline Orvosi Kar & 2602 & 244 \\
\hline Természettudományi Kar & 831 & 106 \\
\hline Összesen & 6683 & 462 \\
\hline
\end{tabular}

Ami a magyar egyetemet illeti, a minisztériumi adatok szerint 3060-at tett ki a beiratkozott hallgatók száma, akiknek közel fele a Jogi és Közgazdaságtudományi Karon tanult. Arányban őket a Bölcsészkar és az Orvosi Kar hallgatói követték. ${ }^{27}$

160. A kolozsvári Bolyai Tudományegyetem diákjainak és tanárainak száma 1945/1946-ban:

\begin{tabular}{|l|c|c|}
\hline & Diákok & Tanárok \\
\hline Jogi és Közgazdaságtudományi Kar & 1500 & 29 \\
\hline Bölcsészkar & 700 & 52 \\
\hline Orvosi Kar & 600 & 155 \\
\hline Természettudományi Kar & 260 & 52 \\
\hline Összesen & 3060 & 288 \\
\hline
\end{tabular}

${ }^{26}$ ANIC, Fond: Ministerul Culturii Naționale şi al Cultelor, inv. 2325, dos. 603, $24-25$. ${ }^{27} \mathrm{Uo}$. 
Sajtóforrások szerint a következő tanévben Kolozsváron több mint 10000 egyetemista volt. Közülük 6500 tanult az I. Ferdinánd Tudományegyetemen, 2500 a Bolyai Tudományegyetemen és 1500 a Temesvárról Kolozsvárra visszaköltözött Agronómián (Nicoară 2010: 261). A háború utáni néhány év mindkét intézmény esetében a fejlesztésekről szólt. Igaz ez a kisebbségi tanintézményként müködő Bolyai Egyetemre is, ahol a folyamatosan növekvő számú diákok oktatását képzett, magyarországi vendégtanárok segítségével biztosították. A romániai egyetemi oktatás kommunista ellenőrzés alá vonása viszont gyorsan éreztette a hatását mindkét intézményben. 1947-től például a Bolyai Egyetemen több nagy tekintélyü professzornak mondtak fel vagy küldték őket nyugdíjba (Pálfy 2008: 291).

Az egyetemi szintü felsőoktatási intézmények száma a második világháború után nőtt meg Erdélyben. A kolozsvári egyetem és a temesvári Politechnika mellé újabb egyetemek sorakoztak fel 1944 után. Temesváron 1944 decemberében királyi rendelettel alapították meg a Nyugati Egyetemet (Universitatea de Vest) hét karral: jog, bölcsészettudomány, orvosi, természettudományok, állatorvosi, gyógyszerészeti és teológia. 1946-ban Magyar Zene- és Színművészeti Intézet alakult Kolozsváron. Brassóban 1948-ban létrejött a Gazdaságtudományi és Tervezési Intézet (Institutul de Ştiințe Economice şi Planificare), Marosvásárhelyen az Orvosi- és Gyógyszerészeti Intézet (Institutul Medico-Farmaceutic), Petrozsényban a Szén Intézet (Institutul Cărbunelui), Brádon a Színesfémtani Intézet (Institutul de Minereuri Neferoase), Kolozsváron az Agrártudományi Intézet (Institutul Agronomic) és Aradon, a temesvári Nyugati Egyetem kihelyezett szakaként az Állatorvosi Kar (Facultatea de Medicină Veterinară).

Az elszaporodó romániai felsőfokú oktatási intézmények nem hozták magukkal a vidék-főváros közötti kiegyenlítődést. A két világháború között a bukaresti egyetem a romániai diákságnak 65,5\%-át tette ki. 1948/1949-re ugyan lecsökkent ez a szám 58,5\%-ra, később pedig 55-56\%-ra, de továbbra is egyértelmü a bukaresti dominancia. Kolozsvár esetében növekedést tapasztalhatunk (11,3\%-ról 17,2\%-ra), majd 1949-től újabb visszaesést, amely a kisebb egyetemi központokban végbement fejlesztéseknek köszönhető.

Az alábbiakban a második világháború után müködő erdélyi egyetemek 1948/1949-es és 1949/1950-es adatait közöljük (Anuarul Statistic 1957: 200-201):

161. Az erdélyi egyetemi karok és a hallgatók létszáma 1948-1949 között:

\begin{tabular}{|l|c|c|c|c|}
\hline \multirow{2}{*}{\multicolumn{1}{|c|}{ Város }} & \multicolumn{2}{|c|}{ Egyetemi karok száma } & \multicolumn{2}{c|}{ Hallgatók száma } \\
\cline { 2 - 5 } & $\mathbf{1 9 4 8 / 1 9 4 9}$ & $\mathbf{1 9 4 9 / 1 9 5 0}$ & $\mathbf{1 9 4 8 / 1 9 4 9}$ & $\mathbf{1 9 4 9 / 1 9 5 0}$ \\
\hline Kolozsvár & 32 & 30 & 8365 & 8200 \\
\hline Temesvár & 14 & 14 & 3655 & 4206 \\
\hline
\end{tabular}


OKTATÁSI INTÉZMÉNYRENDSZER ÉS DIÁKPOPULÁCIÓ ERDÉLYBEN

\begin{tabular}{|l|c|c|c|c|}
\hline Brassó & 2 & 2 & 1482 & 1076 \\
\hline Marosvásárhely & 5 & 5 & 841 & 889 \\
\hline Petrozsény & 1 & 1 & 132 & 178 \\
\hline Brád & 1 & 1 & 112 & 135 \\
\hline Arad & 2 & 2 & 178 & 393 \\
\hline Összesen & 57 & 55 & 14765 & 15077 \\
\hline Románia összesen & 129 & 135 & 48676 & 48615 \\
\hline
\end{tabular}




\section{7. ÖSSZEGZÉS}

Elemzésünkben oktatási szintek és iskolatípusok, iskolafenntartók szerint csoportosítva mutattuk be az erdélyi oktatási intézményeknek és diákjaik számának alakulását. A rendelkezésünkre álló hiányos statisztikák nem tették lehetővé egy mindenre kiterjedő, teljes fejlődésvonal megrajzolását. Ennek ellenére a tanulmányban bemutatott táblázatok alapján többé-kevésbé rekonstruálni lehet az 1918-1948 közötti oktatási piac és iskolai intézményrendszer főbb jellemzőit.

Mindenekelőtt lássuk az erdélyi állami iskolahálózat fejlettségét az országos adatokhoz viszonyítva. A két világháború között a romániai alsó és középfokú oktatási intézményeknek huszonkilenc-harminc százaléka müködött Erdély területén. Ezzel a számmal szinte megegyezik az 5-18 éves iskolaköteles erdélyi gyermekek aránya Románián belül. Látható viszont, hogy az iskolaköteles gyermekek arányához viszonyítva az erdélyi állami iskolahálózat gyorsabban fejlődött, mint a romániai átlag. Ez a különbség pedig az 1930-as évek második felére tovább nőtt Erdély javára. A romániainál gyorsabban bővülő erdélyi állami iskolahálózat azt eredményezte, hogy amíg az 1924/1925-ös tanévben 1 erdélyi állami oktatási intézményre 266,6 iskolaköteles gyermek jutott, addig 1935/1936-ban már csak 219. Ezzel szemben a romániai átlag 1924/1925-ben 264,1, míg 1935/1936-ban 247,6 volt (Statistica învățământului 1931: XIV-XVI., Anuarul Statistic 1939: 201-267). 
162. Az Erdély területén müködő alsó és középfokú oktatási intézmények aránya Románián belül:

\begin{tabular}{|c|c|c|c|c|c|c|}
\hline & \multicolumn{3}{|c|}{ Állami oktatási intézmények } & \multicolumn{3}{|c|}{ 5-18 éves iskolakötelesek } \\
\hline & \multicolumn{2}{|c|}{ Erdély } & \multirow{2}{*}{ Románia } & \multicolumn{2}{|c|}{ Erdély } & \multirow{2}{*}{ Románia } \\
\hline & & $\%$ & & & $\%$ & \\
\hline 1924/1925* & 4138 & 29,1 & 14215 & 1102990 & 29,4 & 3754675 \\
\hline $1928 / 1929$ & 5129 & 29,7 & 17293 & 1051813 & 27,3 & 3847485 \\
\hline $1935 / 1936^{*}$ & 5424 & 30,1 & 18035 & 1187761 & 26,6 & 4466274 \\
\hline
\end{tabular}
tartási iskolák számát.

Tizenegy év leforgása alatt tehát a romániai állami óvodák, elemi iskolák és középfokú tanintézmények száma együttesen 26,9\%-kal, az iskoláskorú lakosságé pedig 19\%-kal gyarapodott. Erdélyben viszont az intézmények növekedése 31,1\%-os volt. A gyorsabb erdélyi fejlődést az itteni iskoláskorú gyermekek száma nem indokolta volna, hiszen ebben a régióban, 1925-höz képest, az 5-18 évesek 7,7\%-kal lettek többen 1936-ra. Ezek az adatok azt mutatják, hogy a két világháború között a román állam jelentős energiákat fektetett be az oktatási infrastruktúra fejlesztésébe és az iskolázottsági szint növelésébe. Amint már a tanulmányunk folyamán is említettük, Constantin Angelescu tanügyminisztersége alatt 1922-ben erőteljes elemi iskolaépítési kampány indult be országszerte. A következő évben, 1923-ban újabb akció kezdődött, amely állami tanítóképzők és középiskolák építését célozta meg (Angelescu 1939: 1-31). A kampány első évében, 1923-ban, az Oktatásügyi Minisztérium 73256807 lejt, 1924-ben pedig 66312465 lejt fordított középiskolák és internátusok építésére, épületek vásárlására és javításokra országos szinten. Az összeg nagysága akkor érzékelhető, ha konkrét eseteket is megvizsgálunk. A gyulafehérvári állami fiúlíceum és internátus épületének a megépítése például, 8269893 lejbe, a máramarosszigeti leánylíceum internátusáé pedig 2334000 lejbe került. A gyulafehérvári intézmény I-VIII. osztályaiba 519 diák járt az 1924/1925-ös tanévben, míg a máramarosszigetibe 368 (Anuarul învățământului secundar 1925: LVI-LVII).

Az első világháború után Romániához csatolt területeken, és különösképpen a Magyarországtól nyert részeken, az országos átlagnál nagyobb mértékben hoztak létre állami iskolákat, vagy úgy, hogy a már meglévő magyar nyelvü intézményeket államosították, vagy új iskolákat építettek. A nagymértékü infrastrukturális fejlesztéseknek lényegében két oka volt. Az állami intézmények révén kívánták megerősíteni az újonnan szerzett területek román lakosságának pozícióját a magyarokkal, németekkel, illetve a kisebbségek által működtetett egyházi iskolákkal szemben. A másik ok az állam által az oktatás irányításában betöltött szerep megváltozása 
volt. Az 1918 előtti Erdélyben, a magyarországi gyakorlatnak megfelelően, az oktatási intézményeket elsősorban az egyházak tartották fent, a háború előtti Romániában viszont az egyházak szerepvállalása elenyésző volt (Livezeanu 1995: 35, Bíró 2002: 145, B. Kovács 1997: 19-21). A román állam tehát lényegében a korábbi iskolapolitikáját kívánta gyakorlatba ültetni az újonnan szerzett területeken is. Mindezeknek az lett az eredménye, hogy amíg az 1920/1921-es tanévben az Erdélyben működő elemi iskoláknak csak 32,7\%-a volt állami és községi fenntartású, addig 1928/1929-re 77,8\%-ra ugrott ez az arány. Habár kisebb mértékben, de ugyanez az arányváltozás figyelhető meg a líceumok és felsőfokú leányiskolák esetében is. Itt az állami intézmények aránya 46,4-ről 64,7\%-ra változott.

A tanerők száma nem állt arányban az intézményi fejlesztések ütemével. 1918 után az Erdélyben berendezkedő román adminisztráció nagyszámú tanítót, tanárt vonzott el az oktatói pályáról, a kisebbségi tanerők közül pedig a román nyelvismeret hiányában számosan elveszítették az állásukat. Ennek következtében az első világháborút követően pedagógushiánnyal küzdöttek az erdélyi iskolák (Balogh 1996: 39). Mindez romániai összehasonlításban is tetten érhető. A két világháború között az erdélyi állami tanszemélyzet $23-27 \%$-ot tett ki a romániai állami pedagógusok között, miközben az állami iskolák 29-30\%-ot a romániai iskolahálózaton belül. Az egy iskolára jutó pedagógusok száma is alacsonyabb volt az országos átlagnál. Erdélyben ugyanis 1928/1929-ben 2,2, míg országos átlagban 2,8 tanító és tanár jutott egy oktatási intézményre. Ugyanígy a diák-tanár arány esetében is tetten érhető az erdélyi lemaradás: Ebben az évben 1 pedagógusra 45 tanuló jutott, országos szinten pedig 43 (Statistica învățământului 1931: 536-675., Anuarul Statistic 1939: 201-267). ${ }^{28}$

163. Az erdélyi és romániai állami tanerók számának alakulása 1924-1935 között:

\begin{tabular}{|c|c|c|c|c|c|}
\hline \multirow{2}{*}{} & \multicolumn{3}{|c|}{ Tanszemélyzet (mesterek nélkül) } & \multicolumn{2}{c|}{$\begin{array}{c}\text { Egy iskolára jutó oktatók } \\
\text { száma }\end{array}$} \\
\cline { 2 - 3 } & \multicolumn{2}{|c|}{ Erdély } & \multirow{2}{*}{ Románia } & \multirow{2}{*}{ Erdély } & Románia \\
\cline { 2 - 3 } & & $\%$ & 34810 & 2,2 & 2,4 \\
\hline $\mathbf{1 9 2 4 / 1 9 2 5}$ & 9289 & 26,7 & 47628 & 2,2 & 2,8 \\
\hline $\mathbf{1 9 2 8 / 1 9 2 9}$ & 11087 & 23,3 & 54067 & 2,5 & 3,0 \\
\hline $\mathbf{1 9 3 5 / 1 9 3 6}$ & 13295 & 24,6 & 5 \\
\hline
\end{tabular}

*Az adatok nem tartalmazzák az ipariskolák, szakiskolák, mezőgazdasági és háztartási iskolák tanerőinek számát.

\footnotetext{
${ }^{28}$ Amennyiben a magántanulókat, családban felkészített tanulókat is beleszámítva vizsgáljuk meg ezt az arányt, akkor 1928/1929-ben Erdélyben egy tanárra 55, országos szinten pedig 50 diák jutott (Statistica învățământului 1931: 536-675., Anuarul Statistic 1939: 201-267).
} 
A román állam azon igyekezete, hogy csökkentse az erdélyi pedagógushiányt, nem volt tehát eredményes. Habár 1924-1935 között 43,1\%-kal nőtt a régió tanszemélyzetének száma, ez még mindig elmaradt az országos növekedési átlagtól (55,3\%). Maga a "pedagógusminőség” is kételyeket ébresztett a kor szakembereiben. Az 1920-as évek elején erőteljes iskolafejlesztésbe kezdő Angelescu-kormányt például erős kritikák érték a tanszemélyzet alulképzettsége miatt. A tanítói gárdának 1/3-át megfelelő végzettség nélküli helyettesítők tették ki (Livezeanu 1995: 39-40., Balogh 1996: 41).

Az erdélyi oktatási rendszer fejlettsége a diáklétszámban és a rendszeresen iskolába járók arányában is lemérhető. Az állami elemi iskolákba beiratkozott tanulóknak 82,7\%-a járt rendszeresen iskolába az 1920-as évek második felében és $67,8 \%$-uk végezte el az iskolát. A romániai átlag ennél alacsonyabb volt: A rendszeres iskolalátogató tanulók aránya $76,7 \%$-ot, a tanulmányaikat befejezőké pedig 62,2\%-ot tett ki (Balogh 1996: 108). Ez az aránybeli különbség nem magyarázható kizárólag az oktatási infrastruktúra minőségével. Az erdélyi magasabb iskolalátogatottsági és iskolavégzési arány legalább annyira volt annak a függvénye is, hogy a gyermekek milyen családi, társadalmi háttérrel rendelkeztek. Erdély népességének kisebb aránya dolgozott az agrárszektorban (69,7\%), mint Románia egyéb területén (72,3\%). Az iparban, kereskedelemben és a szolgáltatásokban viszont többen helyezkedtek el. A felsorolt tényezők következtében az erdélyi szülők nagyobb arányban járatták a gyermekeiket iskolába, illetve nagyobb mértékben támogatták a hosszabb tanulmányi időt.

A két világháború közötti erdélyi oktatási rendszer vizsgálata természetesen akkor lehet teljes, ha az egyházi és más, magánjellegű oktatási intézményekkel is foglalkozunk. Ebben az esetben viszont a statisztikák hiányosságának következtében csak egy tanítási évre, 1928/1929-re összpontosíthatunk.

Ebben az évben az összes alsó és középfokú oktatási intézménynek 78,3\%-a volt állami kézben, és 21,7\%-a egyháziban és magánban. A diákpopuláció megoszlása megközelítőleg azonos arányokat mutatott, enyhe állami lemaradással a magánszektorral szemben. Ha részleteiben vizsgáljuk meg az adatainkat, akkor az állami szektorban az óvodákon kívül mindenhol túlzsúfoltsággal találkozunk. 
164. Az alsó és középfokú intézményeknek és azok diákjainak megoszlása az állami és magánszektor között 1928/1929-ben:29

\begin{tabular}{|c|c|c|c|c|c|c|c|c|c|c|}
\hline & \multicolumn{4}{|c|}{ Állami szektor } & \multicolumn{4}{|c|}{ Egyházi és magánszektor } & \multirow{3}{*}{ 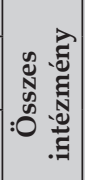 } & \multirow{3}{*}{ 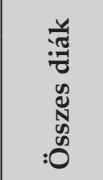 } \\
\hline & \multicolumn{2}{|c|}{$\begin{array}{c}\text { Intézmé- } \\
\text { nyek }\end{array}$} & \multicolumn{2}{|c|}{ Diákok } & \multicolumn{2}{|c|}{$\begin{array}{c}\text { Intézmé- } \\
\text { nyek }\end{array}$} & \multicolumn{2}{|c|}{ Diákok } & & \\
\hline & & $\%$ & & $\%$ & & $\%$ & & $\%$ & & \\
\hline Óvodák & 566 & 86,4 & 40389 & 84,4 & 89 & 13,6 & 7444 & 15,6 & 655 & 47833 \\
\hline Elemi iskolák & 4328 & 77,8 & 423019 & 79,6 & 1234 & 22,2 & 108500 & 20,4 & 5562 & 531519 \\
\hline Tanítóképzők & 30 & 71,4 & 6337 & 85,0 & 12 & 28,6 & 1114 & 15,0 & 42 & 7451 \\
\hline $\begin{array}{l}\text { Gimnáziumok } \\
\text { és I. fokú leány- } \\
\text { középiskolák }\end{array}$ & 65 & 59,1 & 6599 & 60,3 & 45 & 40,9 & 4341 & 39,7 & 110 & 10940 \\
\hline $\begin{array}{l}\text { Líceumok és II. } \\
\text { fokú leány-kö- } \\
\text { zépiskolák }\end{array}$ & 55 & 64,7 & 17329 & 71,0 & 30 & 35,3 & 7077 & 29,0 & 85 & 24406 \\
\hline $\begin{array}{l}\text { Kereskedelmi } \\
\text { iskolák (elemi } \\
\text { és felsőkereske- } \\
\text { delmi) }\end{array}$ & 29 & 78,4 & 3798 & 81,2 & 8 & 21,6 & 882 & 18,8 & 37 & 4680 \\
\hline $\begin{array}{l}\text { Ipariskolák, } \\
\text { szakiskolák, } \\
\text { háztartási } \\
\text { iskolák }\end{array}$ & 56 & 100,0 & 4702 & 100,0 & - & 0,0 & - & 0,0 & 56 & 4702 \\
\hline Összesen & 5129 & 78,3 & 502173 & 79,5 & 1418 & 21,7 & 129358 & 20,5 & 6547 & 631531 \\
\hline
\end{tabular}

Látható az is, hogy az egyházaknak és a magánosoknak elsősorban a középiskolai oktatásban sikerült jobban megőrizniük pozíciójukat. Ismerve azt, hogy ezekbe az intézménytípusokba túlnyomórészt kisebbségi diákok jártak, az egyházi és magánszektor szerepe még jobban felértékelődik a két világháború között.

A diákok iskolafenntartók szerinti etnikai megoszlása azt mutatja, hogy a román tanulók szinte kizárólag állami intézményekben tanultak. A kisebbségi iskolások között is lényeges eltérések figyelhetők meg. Statisztikai számításaink azt mutatják, hogy a legfejlettebb egyházi és magán iskolahálózattal a németek rendelkeztek, akiknél az állami szektorban tanuló gyermekek aránya alig 37,8\% volt. A magyarok esetében ez ötvennégy százalék volt. Jóval szegényesebb oktatási intézményrendszert múködtettek a zsidók, ahol a diákok 73,4\%-a látogatott - elsősorban román tanítási nyelvű - állami iskolát. Ennek és a zsidó iskolákban kötelezően bevezetett román

\footnotetext{
${ }^{29}$ A kimutatás nem teljes, ugyanis nem tartalmazza a mezőgazdasági iskolák adatait, valamint a magántanulók és felnőttképző tanfolyamok diákjainak számát! Ebben az évben, 1928/1929-ben a 631531 iskolába járó diákon kívül további 109735 erdélyi iskoláskorú fiatal volt magántanuló vagy járt felnőttképző tanfolyamra.
} 
(vagy zsidó) tanítási nyelvnek egyenes következménye volt a fiatalabb zsidó generációk lassú disszimilációja a magyarságból, amely elsősorban az autoidentifikációban és csak másodsorban a kultúrafogyasztási gyakorlatok megváltozásában érhető tetten (bővebben lásd: Gidó 2012: 519-532).

165. Az alsó és középfokú oktatásban részt vevő diákok megoszlása iskolafenntartók szerint 1928/1929-ben: ${ }^{30}$

\begin{tabular}{|l|c|c|c|c|c|}
\hline \multirow{2}{*}{} & \multicolumn{2}{|c|}{ Állami szektor } & \multicolumn{2}{c|}{ Egyházi és magánszektor } & \multirow{2}{*}{ Összesen } \\
\cline { 2 - 5 } & & $\%$ & & $\%$ & \\
\hline Románok & 362594 & 99,6 & 1338 & 0,4 & 363932 \\
\hline Németek & 27346 & 37,8 & 44912 & 62,2 & 72258 \\
\hline Magyarok & 86205 & 54,0 & 73406 & 46,0 & 159611 \\
\hline Zsidók & 16340 & 73,4 & 5918 & 26,6 & 22258 \\
\hline
\end{tabular}

A két legnagyobb lélekszámú kisebbség, a magyarok és a németek elitképzése tulajdonképpen kiszorult az általuk fenntartott egyházi és magánintézményekbe, míg a románokét teljes mértékben az állami szektor látta el. A magyar tanítói utánpótlást 84,4\%-ban, a németet pedig 88,4\%-ban az egyházi iskolák végezték. A német és a magyar egyházi líceumok és II. fokú leány-középiskolák a diákok 66,9, illetve 72,5\%-át tudhatták magukénak (lásd a 34-37. sz. mellékleteket).

$\mathrm{Az}$ adatok a kisebbségi elitképzés egy másik vonatkozására is rámutatnak, mégpedig arra, hogy ez az elitképzés erősen humán jellegüvé vált, miközben a közgazdasági tudást szerző magyar felső kereskedelmistáknak csak 54,7\%-a, a németeknek pedig 38,6\%-a járt egyházi oktatási intézménybe. Hasonló problémákat vet fel a szakoktatás helyzete is. Ez a profil ugyanis teljesen hiányzott az egyházi és a magániskolák kínálatából. Igy azok a kisebbségi fiatalok, akik szakmát akartak tanulni, csak állami szakiskolákba, ipariskolákba vagy háztartási iskolákba tudtak beiratkozni (lásd a 34-37. sz. mellékleteket). A tömbmagyar területeken a tanítási nyelv szempontjából mindez nem jelentett különösebb problémát, de azokon a településeken, ahol a kisebbségi lakosság alacsony arányszáma miatt nem múködtek magyar tanítási nyelvü iskolák vagy osztályok, a fiatalok csak román nyelven tudták megszerezni a szaktudást. Ez a jelenség egyébként az általunk vizsgált időszakot követően mindvégig fennállt és korunkban is tapasztalható.

\footnotetext{
${ }^{30}$ A kimutatás nem teljes, ugyanis nem tartalmazza a mezőgazdasági iskolák adatait, valamint a magántanulók és felnőttképző tanfolyamok diákjainak számát!
} 
Az egyes etnikumok közötti iskolázottsági aránytalanságokra több alkalommal is utaltunk a tanulmányunk folyamán. Az 5-18 éves, iskolaköteles fiatalok nemzetiségi megoszlását véve alapul, szembetűnő a kisebbségek felülreprezentáltsága bizonyos oktatási típusok esetében. A nagyobb arányban városlakó és szélesebb munkásréteggel rendelkező kisebbségek például nagyobb jelentőséget tulajdonítottak az óvodai nevelésnek, valamint a társadalmi középosztályban maradást elősegítő, elméleti oktatásban megszerezhető tudásnak. Az iskoláskorúak között 3,2\%-ot képviselő zsidók körében jelentősen nagyobb volt az elemi iskola után továbbtanuló diákok aránya, mint a románok vagy a magyarok esetében. A rendelkezésünkre álló adatok alapján úgy értékeljük, hogy 100 zsidó elemistából megközelítőleg 21 tanult tovább gimnáziumban, líceumban vagy felsőkereskedelmi iskolában. A románok esetében ez 8, a magyarok esetében 9, a németeknél pedig 10 volt (lásd a középiskolai oktatásról szóló fejezet etnikai bontást tartalmazó táblázatait)! Ez a hatalmas különbség vezetett a zsidó diákok felülreprezentáltságához a középfokú elméleti oktatásban (A líceumokban és II. fokú leány-középiskolákban például, 8,7\%-ot alkottak, holott az iskolakötelesek között a zsidók aránya 3,2\% volt).

A román kormány iskolapolitikájára utalnak a román diákság adatai. Az 1918 előtti Romániában - Spiru Haret oktatásügyi miniszter reformjainak köszönhetően, - nagy hangsúlyt fektettek a gyakorlati oktatásra. Ez a fajta szemléletmód Erdélybe is átgyưrűzött, amelynek nyomán az ipariskolákban, szakiskolákban, háztartási iskolákban a román diákság aránya messze meghaladta a kisebbségekét. Ehhez természetesen hozzájárult az, hogy a gyakorlati szakmákat oktató intézmények teljesen állami kézben összpontosultak, és a falaik között többnyire román nyelven zajlott az oktatás. Az sem mellékes, hogy a rurális lakószerkezetű román lakosság számára elsősorban ezek az intézménytípusok voltak hozzáférhetőek.

A pedagógus-utánképzést biztosító tanító- és tanítónőképzőkben is a román diákok aránya volt a domináns, amely a felduzzasztott állami elemi iskolai rendszer tanítóigényét volt hivatott kielégíteni. A kereskedelmi iskolák, valamint a líceumok szintén főként állami kézben összpontosultak (lásd a 164. sz. táblázatot), amely tény a román diákok arányában is megmutatkozott (lásd az 58., a 73. és a 166. sz. táblázatokat). Ezekkel az oktatási intézményekkel tehát az első világháború után nem csak a román népesség oktatási felzárkóztatása indult el, hanem az etnikai jellegü elitcsere (állami hivatalok, kulturális apparátus, szakértelmiség) bázisa is megteremtődött. 
166. Az erdélyi alsó és középfokú oktatási intézményekbe beiratkozott diákok nemzetiségi megoszlása 1928/1929-ben, százalékban kifejezve:

\begin{tabular}{|l|c|c|c|c|c|}
\hline & Román & Német & Magyar & Zsidó & Egyéb \\
\hline Iskolakötelesek & 60,7 & 9,1 & 24,0 & 3,2 & 3,0 \\
\hline Óvodák & 40,7 & 23,2 & 29,6 & 4,8 & 1,8 \\
\hline Elemik & 59,1 & 10,5 & 25,1 & 3,1 & 2,2 \\
\hline Tanító- és tanítónőképzők & 81,9 & 5,2 & 12,2 & 0,2 & 0,5 \\
\hline $\begin{array}{l}\text { Gimnáziumok és I. fokú } \\
\text { leány-középiskolák }\end{array}$ & 36,4 & 19,3 & 33,8 & 7,9 & 2,6 \\
\hline $\begin{array}{l}\text { Líceumok és II. fokú } \\
\text { leány-középiskolák }\end{array}$ & 53,4 & 10,7 & 25,9 & 8,7 & 1,4 \\
\hline $\begin{array}{l}\text { Kereskedelmi iskolák } \\
\text { (elemi, felsőkereskedel- } \\
\text { mi) }\end{array}$ & 63,0 & 7,5 & 18,8 & 9,9 & 0,8 \\
\hline $\begin{array}{l}\text { Ipariskolák, szakiskolák, } \\
\text { háztartási iskolák }\end{array}$ & 91,7 & 1,6 & 4,6 & 0,9 & 1,2 \\
\hline Összes beiratkozott diák & 57,6 & 11,4 & 25,3 & 3,5 & 2,1 \\
\hline
\end{tabular}

A felsőoktatás lényegében leképezte a középiskolai helyzetet. Két esetben, a románok és a zsidók esetében, itt is túliskolázottság figyelhető meg, azzal a lényeges különbséggel, hogy a zsidóknál a tendenciák negatív, a románoknál pedig pozitív irányba mutattak. A két világháború között a kisebbségi értelmiség utánpótlása lelassult, az igényeket nem elégítette ki. Ezzel szemben az érettségit adó középiskolák "elrománosodása” és a felsőoktatásba egyre nagyobb számba bekerülő többségi diákok révén felduzzadt a román diplomások száma.

A két világháború között a romániai egyetemisták száma négyszeresére nőtt (mindeközben a sikeres érettségit letevő diákok körében csak másfélszeres a növekedés), amely az egyetemi szféra túlnépesedéséhez vezetett. Igaz ez a kolozsvári egyetemre is, habár itt a beiratkozottak száma jóval kisebb arányban emelkedett. Az egyetem padjaiból kikerülő diplomások, az értelmiségi munkapiac telítettsége miatt, egyre nehezebben jutottak végzettségüknek megfelelő álláshoz. Mivel a szabadfoglalkozású pályákon, a szakértelmiségben, az 1918 előtti struktúráknak köszönhetően, még mindig a zsidók, a magyarok és a németek voltak túlsúlyban, ${ }^{31}$ az újonnan végzett román fiataloknak azt kellett tapasztalniuk, hogy csak nehézségek árán tudnak elhelyezkedni. A túlnépesedés konfliktushelyzeteket szült, amely elsősorban kisebbségellenes (zsidóellenes) megmozdulásokban öltött testet (Pálfy 2004: 160, Livezeanu 1995: 212-216).

\footnotetext{
${ }^{31}$ Az orvosoknak még 1937-ben is 11,1\%-a volt magyar, 15\%-a német, 32,1\%-a zsidó és 41,1\%-a román. Az ügyvédek között 1936-ban a németek 7\%-ot, magyarok 20,2\%-ot, a zsidók 24,4-et, a románok pedig 47,8\%-ot alkottak. Szél 1940: 696, Kiss 1936: 428.
} 
A román elem túlsúlyba kerülése nem csak a kolozsvári egyetemen figyelhető meg. Az Erdély területén működő egyéb főiskolákban még inkább éreztette hatását a román állam azon törekvése, hogy kinevelje a saját, nemzethü kulturális elitjét. Ezekben az intézményekben, ahol a müvészeti tudás mellett elsősorban szakirányú (műszaki, gazdasági) kompetenciákra lehetett szert tenni, 1935/1936-ban 80,6\% volt a román hallgatók aránya. Amennyiben a felekezeti megoszlást vizsgáljuk, úgy azt látjuk, hogy a görögkeleti és görög katolikus vallású diákok dominanciája még jelentősebb volt $(82,3 \%)$, miközben, ellentétben az I. Ferdinánd Tudományegyetemen tapasztaltakkal, a zsidó hallgatók alulreprezentáltak maradtak. Ez alól kivételt csak a kolozsvári Elektromechanikai Almérnöki Iskola (21\%), valamint a kolozsvári Zene- és Színművészeti Akadémia (6,9\%) képeztek.

167. Az erdélyi felsőoktatási intézményekbe beiratkozott diákok nemzetiségi megoszlása 1935/1936-ban, százalékban kifejezve:32

\begin{tabular}{|l|c|c|c|c|}
\hline & Román & Német & Magyar & Zsidó \\
\hline $\begin{array}{l}\text { I. Ferdinánd } \\
\text { Tudományegyetem }\end{array}$ & 63,6 & 4,6 & 20,5 & 9,9 \\
\hline Egyéb föiskolák & 80,6 & 4,0 & 9,4 & 3,0 \\
\hline Összesen & 69,9 & 4,3 & 16,4 & 7,4 \\
\hline
\end{tabular}

168. Az erdélyi felsőoktatási intézményekbe beiratkozott diákok felekezeti megoszlása 1935/1936-ban, százalékban kifejezve:

\begin{tabular}{|c|c|c|c|c|c|c|c|}
\hline & 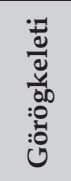 & 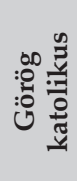 & 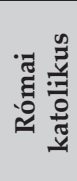 & 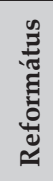 & & 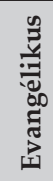 & 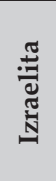 \\
\hline $\begin{array}{l}\text { I. Ferdinánd } \\
\text { Tudományegyetem }\end{array}$ & 38,9 & 25,6 & 12,9 & 7,3 & 1,4 & 4,0 & 9,9 \\
\hline Egyéb főiskolák & 66,2 & 16,1 & 8,6 & 2,8 & 0,8 & 2,0 & 3,0 \\
\hline Összesen & 48,9 & 22,1 & 11,3 & 5,7 & 1,2 & 3,2 & 7,4 \\
\hline
\end{tabular}

Az 1940-es második bécsi döntés pillanatában az erdélyi oktatás tehát teljesen megváltozott képet mutatott az 1918-as állapotokhoz képest. Az Észak-Erdélybe visszatérő magyar adminisztráció visszamagyarosítási folyamatba kezdett az iskolai infrastruktúra minden szintjén. Így például az algimnáziumok 54,3\%-ában folyt román nyelvű oktatás 1939/1940-ben, 1942/1943-ban viszont már csak 2,1\%-ában. A főgimnáziumok többség-

${ }^{32} \mathrm{Az}$ Egyéb fóiskolák kategória a következő, a tanulmányunkban részletesen tárgyalt felsőfokú intézményekre vonatkozik: Elektromechanikai Almérnöki Iskola, Agrártudományi Akadémia, Felsőkereskedelmi és Ipari Akadémia, Zene- és színművészeti Akadémia, Szépművészeti Iskola, Müszaki Főiskola. 
ében is visszaállították a magyar nyelvü tanítást, és visszatért Kolozsvárra az első világháború után Szegedre menekült magyar egyetem. A nem egyetemi fokú oktatási intézményekben a diákok nemzetiségi és felekezeti megoszlása nagyjából az 1941-es népszámlálás eredményeinek felelt meg. Ezzel szemben a kolozsvári egyetemen a magyar diákok kerültek túlsúlyba, érzékeltetve a magyar állam elitképzésben elfoglalt kompenzáló álláspontját a két világháború közötti viszonyokhoz képest. Az erdélyi oktatási rendszernek és az oktatási piacnak az alakulását tehát mindvégig az állam részéről megnyilvánuló politikák (elitképzési stratégia, nemzetiségpolitika) határozták meg. 


\section{BIBLIOGRÁFIA}

\section{Angelescu, Constantin}

[1939] Evoluția învățământului primar şi secundar în ultimii 20 de ani. Imprimeriile „Curentul” S. A., Bucureşti.

1938 Anuar pe anul şcolar 1937-1938. Academia Teologică Ortodoxă Română, Cluj.

1939 Anuar pe anul şcolar 1938-1939. Academia Teologică Ortodoxă Română, Cluj.

1930 Anuarul 1924-1930. Academia Teologică Ortodoxă Română, Cluj.

1937 Anuarul 1935-1937. Academia Teologică Ortodoxă Română, Cluj.

1927 Anuarul învățământului comercial din România pe anul 1926-1927. Ministerul Instrucțiunii. Direcțiunea Generală a Învățământului Profesional, Bucureşti.

1925 Anuarul învățământului particular de grad secundar din România pe anul şcolar 1923-1924. Ministerul Instrucțiunii. Direcțiunea Generală a Invățământului Particular, Confesional şi Minoritar, Bucureşti.

1933 Anuarul Învățământului Primar. Ministerul Instrucțiunii Publice, Cultelor şi Artelor, Bucureşti.

1925 Anuarul învățământului secundar din România pe anul 1924-1925. Ministerul Instrucțiunii. Direcțiunea Generală a Învățământului Secundar, Bucureşti.

1957 Anuarul Statistic al R.P.R. 1957. Editura Ştiințifică, Bucureşti. 
1933 Anuarul Statistic al României 1931-1932. Monitorul Oficial şi Imprimeriile Statului, Bucureşti.

1934 Anuarul Statistic al României 1933. Ministerul Muncii, Sănătății şi Ocrotirilor Sociale. Institutul de Statistică Generală a Statului, Bucureşti.

1935 Anuarul Statistic al României 1934. Ministerul Muncii, Sănătății şi Ocrotirilor Sociale. Institutul de Statistică a Statului, Bucureşti.

1939 Anuarul Statistic al României 1937 şi 1938. Institutul Central de Statistică, Bucureşti.

1940 Anuarul Statistic al României 1939 şi 1940. Institutul Central de Statistică, Bucureşti.

1930 Anuarul Universității Regele Ferdinand I din Cluj 1929-1930. Tipografia Națională S.A., Cluj.

1931 Anuarul Universității Regele Ferdinand I din Cluj 1930-1931. Institutul de Arte Grafice „Ardealul”, Cluj.

1932 Anuarul Universității Regele Ferdinand I din Cluj 1931-1932. Institutul de Arte Grafice „Ardealul”, Cluj.

1933 Anuarul Universității Regele Ferdinand I din Cluj 1932-1933. Institutul de Arte Grafice „Ardealul”, Cluj.

1934 Anuarul Universității Regele Ferdinand I din Cluj 1933-1934. Institutul de Arte Grafice „Ardealul”, Cluj.

1935 Anuarul Universității Regele Ferdinand I din Cluj 1934-1935. Institutul de Arte Grafice „Ardealul”, Cluj.

1939 Anuarul Universității Regele Ferdinand I din Cluj 1937-1938. Tipografia „Cartea Românească”, Cluj.

1940 Anuarul Universității Regele Ferdinand I din Cluj 1938-1939. Tipografia "Cartea Românească”, Cluj.

1943 Anuarul Universității Regele Ferdinand I Cluj-Sibiu. În al doilea an de refugiu 1941-1942. Tipografia „Cartea Românească” din Cluj, Sibiu.

B. Kovács András

1997 Szabályos kivétel. A romániai magyar oktatásügy regénye: 1918, 1944-1948, 1996. Kriterion Könyvkiadó, Bukarest-Kolozsvár. 
BALÁzs Sándor

1929 Adatok az erdélyi kisebbségek iskolavédelmi küzdelmeihez 1919-1929. Minerva Irodalmi és Nyomdai Müintézet Részvénytársaság, Cluj-Kolozsvár.

BALOGH Júlia

1996 Az erdélyi hatalomváltás és a magyar közoktatás 1918-1928. Püski, Budapest.

BARABÁs Béla-Joó Rudolf (szerk.)

1990 A kolozsvári magyar egyetem 1945-ben: A Bolyai Egyetem szervezésének válogatott dokumentumai. Magyarságkutató Intézet, Budapest.

BÁRDi Nándor

2004 Tény és való. A budapesti kormányzatok és a határon túli magyarság kapcsolattörténete. Problémakatalógus. Kalligram Könyvkiadó, Pozsony.

Bíró Sándor

2002 Kisebbségben és többségben. Románok és magyarok 1867-1940. Pro-Print Könyvkiadó, Csíkszereda.

BunEsCu, Gheorghe (coord.)

2004 Antologia legilor învățământului din România. Institutul de Ştiințe ale Educației, Bucureşti.

Caliani, Augustin

1934 L'enseignement minoritaire en Transylvanie. In: Revue de Transylvanie 2 . 153-180.

Chiriacescu, Sergiu T.

1998 Învățământul superior braşovean 1948-1998. Editura Universității Transilvania, Braşov.

Ciobanu, Vasile

2001 Contribuții la cunoaşterea istoriei saşilor transilvăneni 1918-1944.

Editura Hora, Sibiu.

1922 Dare de seamă pe anii 1920/1921 şi 1921/1922. Publicată de Direcțiunea Academiei. Academia de Comerț din Cluj, Cluj. 
1924 Dare de seamă pe anii 1922/1923 şi 1923/1924. Publicată de Rectoratul Academiei. Academia de Înalte Studii Comerciale şi Industriale din Cluj, Cluj.

1926 Dare de seamă pe anii 1924/1925 şi 1925/1926. Publicată de Rectoratul şi Secretariatul Academiei. Academia de Înalte Studii Comerciale şi Industriale din Cluj, Cluj.

1929 Dare de seamă pe anii 1926/1927 şi 1927/1928. Publicată de Rectoratul şi Secretariatul Academiei. Academia de Înalte Studii Comerciale şi Industriale din Cluj, Cluj.

DiAc, Florian

2004 O istorie a învățământului românesc modern. Editura Oscar Print, Bucureşti.

Diószegr László-R. SüLE Andrea

1990 Hetven év. A romániai magyarság története 1919-1989. Magyarságkutató Intézet, Budapest.

DrĂGOESCU, Anton (coord.)

1999 Istoria României. Transilvania. Vol. II (1867-1947). Editura „George Barițiu", Cluj-Napoca.

1951 Egyetemi Fokú Protestáns Theologiai Intézet (Kolozsvár) Évkönyve az 1949, 1949-50 és 1950-1951. tanévről. K. n., Kolozsvár.

1938 Enciclopedia României. vol. 1, Asociația Ştiințifică pentru Enciclopedia României, Bucureşti.

1923 Az Erdélyi Református Egyházkerület Theologiai Fakultásának Értesítője az 1922-1923. tanévről. (szerk. Makkai Sándor) A Ref. Theol. Fakultás Kiadványa, Cluj-Kolozsvár.

1924 Az Erdélyi Református Egyházkerület Theologiai Fakultásának Értesítője az 1923-1924. tanévről. (szerk. Makkai Sándor) A Ref. Theol. Fakultás Kiadványa, Cluj-Kolozsvár.

1925 Az Erdélyi Református Egyházkerület Theologiai Fakultásának Értesítője az 1924-1925. tanévről. (szerk. Tavaszy Sándor) A Ref. Theol. Fakultás Kiadványa, Cluj-Kolozsvár.

1926 Az Erdélyi Református Egyházkerület Theologiai Fakultásának Értesítője az 1925-1926. tanévről. (szerk. Tavaszy Sándor) A Ref. Theol. Fakultás Kiadványa, Cluj-Kolozsvár. 
1927 Az Erdélyi Református Egyházkerület Theologiai Fakultásának Értesítője az 1926-1927. tanévről. (szerk. Tavaszy Sándor) A Ref. Theol. Fakultás Kiadványa, Cluj-Kolozsvár.

1928 Az Erdélyi Református Egyházkerület Theologiai Fakultásának Értesítője az 1927-1928. tanévről. (szerk. Tavaszy Sándor) A Ref. Theol. Fakultás Kiadványa, Cluj-Kolozsvár.

1929 Az Erdélyi Református Egyházkerület Theologiai Fakultásának Értesítője az 1928-1929. tanévről. (szerk. Tavaszy Sándor) A Ref. Theol. Fakultás Kiadványa, Cluj-Kolozsvár.

1930 Az Erdélyi Református Egyházkerület Theologiai Fakultásának Értesítője az 1929-1930. tanévről. (szerk. Tavaszy Sándor) A Ref. Theol. Fakultás Kiadványa, Cluj-Kolozsvár.

1931 Az Erdélyi Református Egyházkerület Theologiai Fakultásának Értesítője az 1930-1931. tanévről. (szerk. Tavaszy Sándor) A Ref. Theol. Fakultás Kiadványa, Cluj-Kolozsvár.

1934 Az Erdélyi Református Egyházkerület Theologiai Fakultásának Értesítője az 1933-1934. tanévről. (szerk. Imre Lajos) A Református Theol. Fakultás Kiadványa, Cluj-Kolozsvár.

1939 Az Erdélyi Református Egyházkerület Theologiai Fakultásának Értesítője az 1938-1939. tanévről. (szerk. Gönczy Lajos) A Ref. Theol. Fakultás Kiadványa, Cluj-Kolozsvár.

1940 Az Erdélyi Református Egyházkerület Theologiai Fakultásának Értesítője az 1939-1940. tanévről. (szerk. Gönczy Lajos) A Ref. Theol. Fakultás Kiadványa, Cluj-Kolozsvár.

1941 Az Erdélyi Református Egyházkerület Theologiai Fakultásának Értesítője az 1940-1941. tanévről. (szerk. Gönczy Lajos) A Ref. Theol. Fakultás Kiadványa, Kolozsvár.

1942 Az Erdélyi Református Egyházkerület Theologiai Fakultásának Értesítője az 1941-1942. tanévről. (szerk. Gönczy Lajos) A Ref. Theol. Fakultás Kiadványa, Kolozsvár.

1943 Az Erdélyi Református Egyházkerület Theologiai Fakultásának Évkönyve az 1942-1943. tanévről. (szerk. Gönczy Lajos) A Református Theol. Fakultás Kiadványa, Kolozsvár.

Fleisz János

2005 Egy város átalakulása. Nagyvárad a két világháború között 1919-1940. Literator, Nagyvárad. 
GAAL György

2001 Egyetem a Farkas utcában. A kolozsvári Ferenc József Tudományegyetem előzményei, korszakai és vonzatai. Erdélyi Magyar Müszaki Tudományos Társaság, Kolozsvár.

Gidó Attila

2006 Jogkorlátozás, kirekesztés és antiszemitizmus Kolozsváron (1918-1940). In: BRAHAM, Randolph L. (szerk.): Tanulmányok a holokausztról IV. Presscon Kiadó, Budapest, 17-55.

2012 Zsidó oktatásügy Kolozsváron a két világháború között. In: Biró Zsuzsanna Hanna-Nagy Péter Tibor (szerk.): Zsidóság - tradicionalitás és modernitás. Tisztelgő kötet Karády Viktor 75. születésnapja alkalmából. WJLF, Budapest, 519-532.

Giurescu, Constantin C. (coord.)

1971 Istoria învățământului din România. Compendiu. Editura didactică şi pedagogică, Bucureşti.

GYÉmÁnt, Ladislau

2004 Evreii din Transilvania. Destin istoric. Centrul de Studii Translivane-Institutul Cultural Român, Cluj-Napoca.

IANCU, Gheorghe

1970 Învăţământul primar şi secundar în Transilvania în perioada activității Consiliului Dirigent (1918-1920). In: Anuarul Institutului de Istorie din Cluj, Tom. XIII. 251-265.

JAKó Zsigmond

1992 Másfél évszázad az erdélyi honismeret szolgálatában. In: Erdélyi Múzeum 1-4. (54) 150-155.

KAcsó Sándor (szerk.)

1937 Erdélyi Magyar Évkönyv 1938. A kisebbségi magyar polgár kézikönyve. A Brassói Lapok és a Népújság Kiadása, Brassó.

KARÁDy Viktor

1997 Iskolarendszer és felekezetei egyenlőtlenségek Magyarországon (1867-1945). Replika Kör, Budapest.

Karády, Viktor-Nagy, Péter Tibor

2009 Educational Inequalities and Denominations, 1910. vol. 3. Database for Transylvania. John Wesley Publisher, Budapest. 
KARADY, Victor-NaSTASă, Lucian

2004 The University of Kolozsvár and the Students of Medical Faculty: 1872-1918. Central European University, Budapest.

Kepecs József (szerk.)

2001 Erdély településeinek vallási adatai (1880-1941). I. köt., Központi Statisztikai Hivatal, Budapest.

Kiss András

2003 Más források - más értelmezések. Mentor Kiadó, Marosvásárhely. Kiss Árpád

1936 A romániai magyar ügyvédek. Magyar Kisebbség 15-16. (15) 428-433.

Kiss Tamás

2010 Támpontok az erdélyi etnikai rétegződési rendszer vizsgálatához,

I. Pro Minoritate 2. (20) 3-28.

Kornis Gyula (szerk.)

1927 Az elszakított magyarság közoktatásügye. A Magyar Pedagógiai Társaság Kiadása, Budapest.

LĂPTOIU, Negoiță

1999 Şcoala de Arte Frumoase din Cluj şi Timişoara (1925-1941). Editura ARC 2000, Bucureşti.

Lázok János-Vincze Gábor

1998 Erdély magyar egyeteme 1944-1949. Dokumentumok, 1945-1949.

Custos-Mentor, Marosvásárhely.

LivezeANu, Irina

1995 Cultural Politics in Greater Romania. Regionalism, Nation Building, and Ethnic Struggle, 1918-1930. Cornell University Press, Ithaca and London.

1943 Magyar statisztikai évkönyv 1941. Országos Magyar Királyi Statisztikai Hivatal, Budapest.

1944 Magyar statisztikai évkönyv 1942. Országos Magyar Királyi Statisztikai Hivatal, Budapest.

1919 A Magyarországi Unitárius Egyház Kolozsvári Teológiai Akadémiájának értesítője az 1918-1919. évről. (szerk. Gálfi Lőrinc) Nyomtatott Kupferstein Testvérek könyvnyomdájában, Cluj-Kolozsvár. 
1919 A Magyarországi Unitárius Egyház Kolozsvári Teológiai Akadémiájának értesítője az 1919-1920. évről. (szerk. Gálfi Lőrinc) Stief Jenő és Társa Könyvsajtója, Cluj-Kolozsvár.

1921 A Magyar Unitárius Egyház Kolozsvári Theológiai Akadémiájának értesítője az 1920-1921. iskolai évről. (szerk. Csifó Salamon) Minerva Irodalmi és Nyomdai Múintézet, Cluj-Kolozsvár.

1926 A Magyar Unitárius Egyház Kolozsvári Teológiai Akadémiájának értesítője az 1925-1926. iskolai évről. (szerk. Kiss Elek) Nyomatott a „Corvin" Könyvnyomdai Múintézetben, Cluj-Kolozsvár.

1929 A Magyar Unitárius Egyház Kolozsvári Teológiai Akadémiájának értesítője az 1928-1929. iskolai évról. (szerk. Csifó Salamon) Nyomatott a „Corvin” Könyvnyomdai Müintézetben, Cluj-Kolozsvár.

1930 A Magyar Unitárius Egyház Kolozsvári Teológiai Akadémiájának értesítője az 1929-1930. iskolai évról. (szerk. Csifó Salamon) Nyomatott a „Corvin” Könyvnyomdai Müintézetben, Cluj-Kolozsvár.

1931 A Magyar Unitárius Egyház Kolozsvári Teológiai Akadémiájának értesítője az 1930-1931. iskolai évről. (szerk. Csifó Salamon) Nyomatott a „Corvin” Könyvnyomdai Müintézetben, Cluj-Kolozsvár.

1932 A Magyar Unitárius Egyház Kolozsvári Teológiai Akadémiájának értesítője az 1931-1932. iskolai évről. (szerk. Csifó Salamon) Nyomatott a „Corvin" Könyvnyomdai Müintézetben, Cluj-Kolozsvár.

1933 A Magyar Unitárius Egyház Kolozsvári Teológiai Akadémiájának értesítője az 1932-1933. iskolai évről. (szerk. Csifó Salamon) Nyomatott a „Corvin” Könyvnyomdai Müintézetben, Cluj-Kolozsvár.

1935 A Magyar Unitárius Egyház Teológiai Akadémiájának értesítője az 1934-1935. iskolai évről. (szerk. Vári Albert) Tipografia „Orient” Könyvnyomda, Cluj.

ManuiLă, Sabin (red.)

1938 Recensământul general al Populației României din 29 decemvrie 1930. Vol. 3, Institutul Central de Statistică, Bucureşti.

Мıко́ Imre

1941 Huszonkét év. Az erdélyi magyarság politikai története 1918. december 1-től 1940. augusztus 30-ig. Stúdium, Budapest. 
MogA, Valer

2003 Astra şi Societatea 1918-1930. Presa Universitară Clujeană, ClujNapoca.

Moraru, Alexandru

1996 Învățământul teologic universitar ortodox din Cluj (1924-1952).

Presa Universitară Clujeană, Cluj-Napoca.

NAGy Lajos

1944 A kisebbségek alkotmányjogi helyzete Nagyromániában. ETI, Kolozsvár.

NicoARă, Mihai Teodor

2010 Istoria Universității din Cluj. De la Universitatea „Regele Ferdinand I" la Universitatea „Babeş-Bolyai” (1945-1959). Teză de doctorat, Universitatea „Babeş-Bolyai”, Cluj-Napoca.

PÁLFY Zoltán

2004 Nemzetállam és felsőoktatási piac. Adatok a kolozsvári egyetem diákságának etnikai és társadalmi összetételéről a két világháború között. Erdélyi Társadalom 2. (2) 151-180.

2008 Cluj Higher Learning in the Early Communist Period: Ethnic Division Reasserted in a Nationalized Market. In: Anuarul Institutului de Istorie „G. Barițiu” din Cluj-Napoca XLVII. 283-307.

Puşcaş, Vasile (szerk.)

1999 University and Society: A History of Higher Education in Cluj in the 20th Century. Cluj University Press, Cluj-Napoca.

1936 A Református Theologiai Fakultás értesítője az 1935-1936. tanévről. (szerk. Imre Lajos) A Ref. Theol. Fakultás Kiadványa, Cluj-Kolozsvár.

1937 A Református Theologiai Fakultás értesítője az 1936-1937. tanévről. (szerk. Gönczy Lajos) A Ref. Theol. Fakultás Kiadványa, Cluj-Kolozsvár.

1938 A Református Theologiai Fakultás értesítője az 1937-1938. tanévről. (szerk. Gönczy Lajos) A Ref. Theol. Fakultás Kiadványa, Cluj-Kolozsvár.

RónAi András

1934 Az erdélyi magyarság népoktatásügyének statisztikai mérlege a másfél évtizedes román uralom alatt. Magyar Statisztikai Szemle 12. (10) 851-871. 
Rotariu, Traian (coord.)

1999 Recensământul din 1910. Transilvania. Editura Staff, Cluj-Napoca.

2002 Recensământul din 1941. Transilvania. Presa Universitară Clujeană, Cluj-Napoca, 2002.

SCURTu, Ioan (coord.)

2003 Istoria românilor. Vol. VIII. România întregită. Editura Enciclopedică, Bucureşti.

SEBEstyén Kálmán

1998 Román iskolák Észak-Erdélyben (1940-1944). Limes 4. (11) 167-171.

1924 Statistica învățământului public şi particular din România pe anii şcolari 1919-1920 şi 1920-1921. Ministerul Instrucțiunii. Direcția Generală a Statisticii Învățământului, Statelor Personale şi Arhivelor, Bucureşti.

1931 Statistica învățământului din România pe anii şcolari 1921/1922-1928/1929. Ministerul Instrucțiunii, al Cultelor şi Artelor. Secretariatul General, Secția de Studii, Documentare şi Statistică, Bucureşti.

SuLYok István-Fritz László (szerk.)

1930 Erdélyi magyar évkönyv 1918-1929. I. évf. Juventus Kiadás, Kolozsvár.

SzÉL Tivadar

1940 A visszacsatolt keleti terület. Közegészségügy. Magyar Statisztikai Szemle 8-9. (XVIII) 685-696.

Szlucska János

2009 „Pünkösdi királyság.” Az észak-erdélyi oktatásügy története 1940-1944. Gondolat Kiadó, Budapest.

1940 Tabloul şcolilor primare particulare şi confesionale. Anul şcolar 1939/1940. Ministerul Educației Naționale. Direcțiunea Învățământului Particular şi Confesional, Bucureşti.

Tismăneanu, Vladimir-Dobrincu, Dorin-Vasile, Cristian (szerk.)

2007 Comisia Prezindențială pentru Analiza Dictaturii Comuniste din România. Raport Final. Humanitas, Bucureşti.

Тóтн Ágnes

1998 Nemzetiségi népiskolák Magyarországon az 1943/44-es tanévben.

Bács-Kiskun Megyei Önkormányzat Levéltára, Kecskemét. 


\section{TöRöк Borbála Zsuzsanna}

2008. The Ethnic Design of Scholarship. Learned Societies and State Intervention in $19^{\text {th }}$ Century Transylvania. Karady, Victor-Török Borbála Zsuzsanna (szerk.): Cultural Dimensions of Elite Formation in Transylvania (1770-1950). Ethnocultural Diversity Resource Center, ClujNapoca, 115-137.

1936 Az Unitárius Egyház Teológiai Akadémiájának értesítője az 1935-1936. iskolai évröl. (szerk. Vári Albert) Tipografia „Pallas” Könyvnyomda, Cluj. 1937 Az Unitárius Egyház Teológiai Akadémiájának értesítője az 1936-1937. iskolai évről. (szerk. Vári Albert) Tipografia „Pallas” Könyvnyomda, Cluj. 1938 Az Unitárius Egyház Teológiai Akadémiájának értesítője az 1937-1938. iskolai évről. (szerk. Kiss Elek) Tipografia „Pallas” Könyvnyomda, Cluj. 1939 Az Unitárius Egyház Teológiai Akadémiájának értesítője az 1938-1939. iskolai évről. (szerk. Kiss Elek) Tipografia „Pallas” Könyvnyomda, Cluj. 1940 Az Unitárius Egyház Teológiai Akadémiájának értesítője az 1939-1940. iskolai évről. (szerk. Fikker János) Tipografia „Pallas” Sokszorosító Ipari Szövetkezet, Kolozsvár.

1941 Az Unitárius Egyház Teológiai Akadémiájának értesítője az 1939-1940. iskolai évről. (szerk. Fikker János) „Pallas” Könyvnyomda, Kolozsvár.

1942 Az Unitárius Egyház Teológiai Akadémiájának értesítője az 1941-1942. iskolai évről. (szerk. Abrudbányai János) Lengyel Albert Könyvnyomdája, Kolozsvár.

VARGA E. Árpád

1998 Fejezetek a jelenkori Erdély népesedéstörténetéből. Tanulmányok. Püski, Budapest.

Viman, Ioan

2007 Învățământul secundar din părțile sătmărene în perioada interbelică: 1919-1940. Editura Muzeului Sătmărean, Satu Mare.

\section{VinCZe Gábor}

1999 Illúziók és csalódások. Fejezetek a romániai magyarság második világháború utáni történetéből. Státus Könyvkiadó, Csíkszereda.

WAGNER, Richard

2000 Ethnic Germans in Romania. In: Wolf, Stefan (ed.): German Minorities in Europe. Ethnic Identity and Cultural Belonging. Berghahn Books, New York, Oxford, 135-142. 
ZACH, Cornelius R.

2001 Saşii între tradiție şi noi opțiuni politice 1930-1944. In: Transilvania şi saşii ardeleni în istoriografie. Din publicațiile Asociației Studii Transilvane Heidelberg. Editura Hora, Arbeitskreis für Siebenbürgische Landeskunde, Sibiu, Heidelberg, 171-183. 


\section{MELLÉKLETEK}

1. Az erdélyi iskoláskorúak korcsoportonkénti megoszlása falvakon és városokon:

\begin{tabular}{|c|c|c|c|c|c|c|c|c|c|c|}
\hline \multirow{2}{*}{\multicolumn{2}{|c|}{$\begin{array}{c}\text { Iskoláskorúak } \\
\text { Erdélyben }\end{array}$}} & \multicolumn{2}{|c|}{ 5-7 éves } & \multicolumn{2}{|c|}{ 7-16 éves } & \multicolumn{2}{|c|}{ 16-18 éves } & \multicolumn{2}{|c|}{ Összesen } & \multirow{2}{*}{$\begin{array}{l}\text { Összes } \\
\text { fiú és } \\
\text { lány }\end{array}$} \\
\hline & & Fiú & \multirow[t]{4}{*}{ Lány } & Fiú & Lány & Fiú & Lány & Fiú & Lány & \\
\hline \multirow{3}{*}{1924} & Falvak & & & 323619 & 308780 & & & & & 632399 \\
\hline & Városok & & & 58526 & 53145 & & & & & 111671 \\
\hline & Összesen & & & 382145 & 361925 & & & & & 744070 \\
\hline \multirow{3}{*}{1925} & & 79137 & 76128 & 332997 & 318408 & 80908 & 74243 & 493042 & 468779 & 961821 \\
\hline & Városok & 10 & 9788 & 51669 & 49627 & 11153 & 8750 & 73004 & & 141169 \\
\hline & Ös & 89319 & 5916 & 384666 & 368035 & 2061 & 82993 & 566046 & 536944 & 1102990 \\
\hline \multirow{3}{*}{1926} & & 81 & 87991 & 304280 & 291240 & 74804 & 69334 & 469765 & 65 & 918330 \\
\hline & Városok & 11143 & 11237 & 51103 & 46044 & 8783 & 6473 & 71029 & 63754 & 134783 \\
\hline & Összesen & 101824 & 99228 & 355383 & 337284 & 83587 & 75807 & 540794 & 512319 & 1053113 \\
\hline \multirow{3}{*}{1927} & & 9543 & 93163 & 303658 & 290179 & 00200 & 62050 & 467374 & & 912766 \\
\hline & Városok & 11516 & 11231 & 52552 & 46406 & 10116 & 6119 & 74184 & 63756 & 137940 \\
\hline & Öss & 21059 & 104394 & 356210 & 336585 & 78396 & 68169 & 541558 & 509148 & 1050706 \\
\hline \multirow{3}{*}{1928} & & 7 & 96470 & 31 & 298297 & 631 & 56429 & 47 & 51259 & 926958 \\
\hline & Városok & 12910 & 12629 & 53131 & 46886 & 9666 & 5393 & 75707 & 64908 & 140615 \\
\hline & Összesen & 112287 & 109099 & 366262 & 345183 & 72857 & 61822 & 551406 & 516104 & 1067510 \\
\hline \multirow{3}{*}{1929} & Falvak & 744 & 94256 & 314345 & 299555 & 59984 & 54282 & 470073 & 448093 & 918166 \\
\hline & Városok & 11822 & 11502 & 51020 & 44954 & 9310 & 5039 & 72152 & 61495 & 133647 \\
\hline & Öss & 107566 & 105758 & 365365 & 344509 & 69294 & 59321 & 542225 & 509588 & 1051813 \\
\hline \multirow{3}{*}{1931} & & 95262 & 92480 & 343834 & 328884 & 46222 & 41502 & 485318 & 462866 & 948184 \\
\hline & Városok & 11354 & 11072 & 55234 & 50747 & 7866 & 4231 & 74454 & 66050 & 140504 \\
\hline & Öss & 106616 & 103552 & 399068 & 379631 & 54088 & 45733 & 559772 & 528916 & 1088688 \\
\hline \multirow{3}{*}{1933} & & 95562 & 90242 & 384661 & 370662 & 28230 & 25118 & 508453 & 486022 & 994475 \\
\hline & Városok & 10001 & 9844 & 55884 & 52250 & 4966 & 2766 & 70851 & 64860 & 135711 \\
\hline & Összesen & 105563 & 100086 & 440545 & 422912 & 33196 & 27884 & 579304 & 550882 & 1130186 \\
\hline \multirow{3}{*}{1936} & Falvak & 94594 & 91886 & \begin{tabular}{|l|}
396537 \\
\end{tabular} & 380635 & 40716 & 36793 & 531847 & 509314 & 1041161 \\
\hline & Városok & 9745 & 9605 & 60605 & 56044 & 6602 & 3999 & 76952 & 69648 & 146600 \\
\hline & Összesen & 104339 & 101491 & 457142 & 436679 & 47318 & 40792 & 608799 & 578962 & 1187761 \\
\hline \multirow{3}{*}{1937} & \begin{tabular}{|l|} 
Falvak \\
\end{tabular} & 94642 & 92296 & 395601 & 378906 & 45133 & 41624 & 535376 & 512826 & 1048202 \\
\hline & Városok & 10391 & 10128 & 62163 & 57202 & 8661 & 4969 & 81215 & 72299 & 153514 \\
\hline & Összesen & 105033 & 102424 & 457764 & 436108 & 53794 & 46593 & 616591 & 585125 & 1201716 \\
\hline
\end{tabular}




\begin{tabular}{|c|c|c|c|c|c|c|c|c|c|c|c|c|c|c|c|c|}
\hline \multirow{2}{*}{ 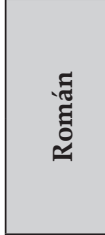 } & 注 & $\begin{array}{l}\stackrel{3}{+} \\
\stackrel{1}{ } \\
\stackrel{N}{N}\end{array}$ & $\begin{array}{l}9 \\
\text { \& } \\
\infty \\
\sim\end{array}$ & 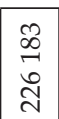 & 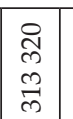 & 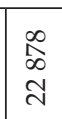 & $\begin{array}{l}\infty \\
2 \\
0 \\
\infty \\
\infty\end{array}$ & $\mid \begin{array}{l}\mathbf{H} \\
\text { a } \\
\text { ते }\end{array}$ & $\mid \begin{array}{l}\Delta \\
0 \\
\vec{d} \\
\vec{N}\end{array}$ & 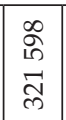 & 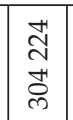 & 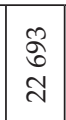 & 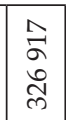 & 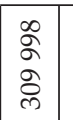 & 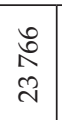 & $\begin{array}{l}\text { t. } \\
0 \\
\infty \\
c\end{array}$ \\
\hline & 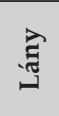 & $\begin{array}{l}\text { कo } \\
o \\
\delta \\
2 \\
2\end{array}$ & 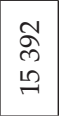 & 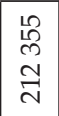 & \begin{tabular}{|l|}
$\overrightarrow{5}$ \\
10 \\
$\hat{\alpha}$ \\
సे
\end{tabular} & $\begin{array}{l}\text { 2. } \\
\text { ลे } \\
\text { रे }\end{array}$ & $\begin{array}{l}\infty \\
\infty \\
10 \\
\infty \\
m \\
m\end{array}$ & 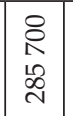 & 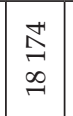 & \begin{tabular}{|l|}
\multirow{2}{*}{} \\
$\infty$ \\
0 \\
0 \\
0 \\
\end{tabular} & 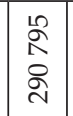 & \begin{tabular}{|l|}
\multirow{2}{0}{} \\
0 \\
$\infty$ \\
-1 \\
\end{tabular} & 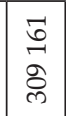 & $\begin{array}{l}0 \\
0 \\
0 \\
0 \\
\text { 11 }\end{array}$ & $\begin{array}{l}\infty \\
\infty \\
\infty \\
2\end{array}$ & $\begin{array}{l}10 \\
\stackrel{10}{10} \\
\vec{m} \\
m\end{array}$ \\
\hline \multirow{4}{*}{ 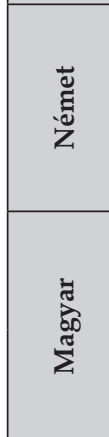 } & 涅 & 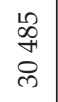 & $\underset{\infty}{\stackrel{1}{2}}$ & $\begin{array}{l}\overrightarrow{\hat{N}} \\
\text { cे }\end{array}$ & $\begin{array}{l}\vec{I} \\
\vec{J}\end{array}$ & ס̊ & $\begin{array}{l}\overrightarrow{\tilde{D}} \\
0 \\
i n\end{array}$ & $\mid \begin{array}{l}\tilde{N} \\
\tilde{Z} \\
\tilde{Z}\end{array}$ & $\mid$\begin{tabular}{l}
$\stackrel{0}{1}$ \\
$\stackrel{1}{0}$ \\
\hdashline
\end{tabular} & $\begin{array}{l}\hat{\Omega} \\
\hat{n} \\
i ̂ n\end{array}$ & $\mid \begin{array}{l}\overrightarrow{1} \\
\infty \\
\infty \\
\infty\end{array}$ & 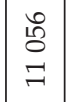 & $\begin{array}{l}R \\
\infty \\
\infty \\
i n \\
10\end{array}$ & $\begin{array}{l}m \\
0 \\
0 \\
0 \\
y\end{array}$ & $\begin{array}{l}\mathbb{H} \\
\stackrel{1}{*} \\
\exists\end{array}$ & $\begin{array}{l}\text { 官 } \\
\text { in }\end{array}$ \\
\hline & 胥 & 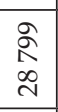 & $\begin{array}{l}4 \\
\infty \\
\infty\end{array}$ & \begin{tabular}{|l|}
\multirow{2}{n}{} \\
$\stackrel{1}{m}$ \\
\end{tabular} & \begin{tabular}{|l|}
\multirow{2}{*}{} \\
I \\
I \\
\end{tabular} & $\underset{\infty}{\stackrel{\Delta}{\Delta}}$ & $\begin{array}{l}\text { से } \\
\text { ñ } \\
\text { in } \\
\end{array}$ & 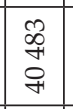 & $\mid$\begin{tabular}{l}
$\infty$ \\
\multirow{2}{*}{} \\
|
\end{tabular} & \begin{tabular}{|l|}
$\vec{i}$ \\
0 \\
in \\
\end{tabular} & \begin{tabular}{|l|} 
\\
$\infty$ \\
$\infty$ \\
$\infty$ \\
0 \\
$\infty$
\end{tabular} & హิ & 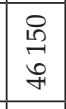 & \begin{tabular}{|l|} 
R \\
8 \\
مे \\
\end{tabular} & 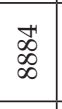 & $\begin{array}{l}\text { 各 } \\
\text { \& }\end{array}$ \\
\hline & 湿 & $\begin{array}{l} \\
5 \\
0 \\
0 \\
0\end{array}$ & \begin{tabular}{|l|}
$\widetilde{N}$ \\
$\stackrel{n}{n}$ \\
$\vec{N}$
\end{tabular} & $\begin{array}{l}0 \\
2 \\
\infty \\
2 \\
2\end{array}$ & \begin{tabular}{l|} 
\\
8 \\
$o$ \\
$o$ \\
$\ddots$ \\
$=$
\end{tabular} & 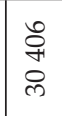 & $\begin{array}{l}\text { o } \\
\text { D } \\
F \\
F\end{array}$ & \begin{tabular}{|l|}
\multirow{1}{*}{} \\
$\infty$ \\
0 \\
0 \\
\end{tabular} & \begin{tabular}{|l|}
$\overrightarrow{3}$ \\
0 \\
$\infty$ \\
\end{tabular} & \begin{tabular}{|c|}
$\vec{i}$ \\
$\stackrel{\vec{q}}{ }$ \\
$\stackrel{2}{a}$ \\
\end{tabular} & \begin{tabular}{|l|} 
\\
0 \\
0 \\
8 \\
0
\end{tabular} & \begin{tabular}{|l|} 
\\
ली \\
సे \\
\end{tabular} & $\begin{array}{l}\vec{s} \\
0 \\
\tilde{m} \\
\end{array}$ & 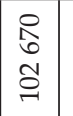 & 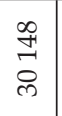 & $\begin{array}{l}\infty \\
\infty \\
心 \\
心 \\
\sim\end{array}$ \\
\hline & 氙 & 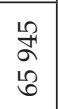 & $\begin{array}{l} \\
\infty \\
\text { i } \\
\text { ते }\end{array}$ & $\begin{array}{l}\vec{\infty} \\
0 \\
\infty \\
\infty\end{array}$ & 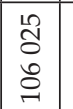 & $\begin{array}{l}0 \\
\infty \\
\infty \\
\infty \\
\sim\end{array}$ & $\begin{array}{l} \\
\infty \\
\infty \\
1 \\
0 \\
1\end{array}$ & $\begin{array}{l}0 \\
0 \\
0 \\
0 \\
0\end{array}$ & 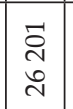 & 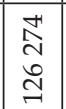 & 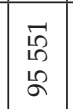 & 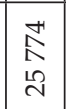 & 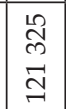 & $\begin{array}{l}10 \\
\infty \\
\infty \\
0 \\
0\end{array}$ & 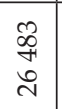 & 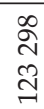 \\
\hline \multirow{2}{*}{ 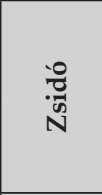 } & 浔 & స్ & 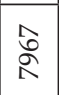 & 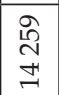 & \begin{tabular}{|l|}
8 \\
d \\
0 \\
\end{tabular} & 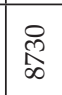 & $\begin{array}{l}\text { ปิ } \\
\text { ปิ }\end{array}$ & \begin{tabular}{|l|} 
\\
\\
$\infty$ \\
$\infty$
\end{tabular} & 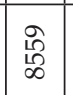 & 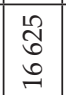 & $\begin{array}{l}0 \\
\bar{\alpha} \\
\overline{2}\end{array}$ & 荵 & $\begin{array}{l}\hat{~} \\
\stackrel{\circ}{0} \\
\end{array}$ & $\underset{\infty}{\mathbb{N}}$ & 音 & $\begin{array}{l}\overrightarrow{8} \\
\text { 의 }\end{array}$ \\
\hline & 窵 & $\begin{array}{l}0 \\
\text { o } \\
0 \\
0\end{array}$ & $\begin{array}{l}\stackrel{\circ}{\circ} \\
\stackrel{\alpha}{\wedge}\end{array}$ & \begin{tabular}{|l|}
$\infty$ \\
$\infty$ \\
\multirow{\sim}{*}{} \\
\multirow{2}{*}{}
\end{tabular} & \begin{tabular}{|l|}
$\infty$ \\
\multirow{\sigma}{\sigma}{} \\
\end{tabular} & $\begin{array}{l}\infty \\
\infty \\
\infty\end{array}$ & $\begin{array}{l}\vec{\aleph} \\
\stackrel{\wedge}{\curvearrowright}\end{array}$ & 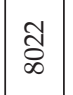 & 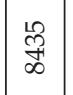 & \begin{tabular}{|l|}
\multirow{2}{9}{} \\
a \\
6 \\
\end{tabular} & $\begin{array}{l}\text { से } \\
\text { 至 }\end{array}$ & 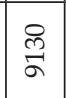 & \begin{tabular}{l}
\multirow{2}{*}{} \\
$\stackrel{\Delta}{a}$
\end{tabular} & $\begin{array}{l}\infty \\
\infty \\
\infty\end{array}$ & $\begin{array}{l}m \\
\overrightarrow{0} \\
\infty\end{array}$ & $\begin{array}{l}\text { 유 } \\
\text { o }\end{array}$ \\
\hline \multirow{2}{*}{ 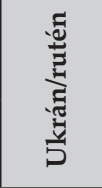 } & 浔 & $\begin{array}{l}\stackrel{\mathbb{N}}{N} \\
\stackrel{N}{N}\end{array}$ & ते & तิ & $\begin{array}{l}\infty \\
\infty \\
\infty \\
\sim\end{array}$ & $\infty$ & $\begin{array}{l}\text { ¿ু } \\
\text { సे }\end{array}$ & $\frac{7}{2}$ & ஜ & 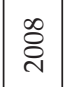 & 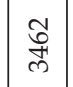 & $\underset{F}{\sharp}$ & $\begin{array}{l}\text { \& } \\
\text { ల) }\end{array}$ & $\begin{array}{l}\infty \\
\text { 車 }\end{array}$ & 胥 & 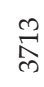 \\
\hline & 胥 & $\begin{array}{l}\infty \\
\stackrel{\infty}{\mathrm{N}} \\
\end{array}$ & $\stackrel{\infty}{\circ}$ & $\overrightarrow{\mathrm{N}}$ & $\begin{array}{l}\hat{N} \\
\text { N } \\
\text { N }\end{array}$ & 8 & $\begin{array}{l}\text { ते } \\
\text { ते }\end{array}$ & 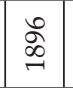 & $\vec{\infty}$ & 点 & $\begin{array}{l}\text { भु } \\
\text { लै }\end{array}$ & 음 & $\begin{array}{l}\text { 今 } \\
\text { ल } \\
\text { लn }\end{array}$ & 鿖 & $\stackrel{\infty}{\circ}$ & 衤 \\
\hline \multirow{2}{*}{ 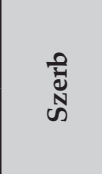 } & 浔 & 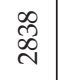 & $\begin{array}{l}\infty \\
\infty \\
\infty\end{array}$ & $\frac{\stackrel{+}{c}}{m}$ & 胥 & $\begin{array}{l}\infty \\
\stackrel{\text { N }}{ }\end{array}$ & 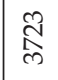 & $\frac{\hat{A}}{7}$ & ळे & 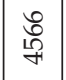 & 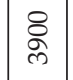 & ర్లి & $\begin{array}{l}\mathscr{O} \\
\mathscr{J} \\
\end{array}$ & 蒿 & 尽 & 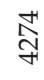 \\
\hline & 氖 & $\begin{array}{l}\mathscr{L} \\
\stackrel{1}{0} \\
\mathbb{N}\end{array}$ & 워 & ठั & \begin{tabular}{|l|}
$\widehat{N}$ \\
$\tilde{ల}$ \\
\end{tabular} & तु & $\begin{array}{l}\vec{D} \\
\stackrel{0}{\circ}\end{array}$ & $\begin{array}{l}\infty \\
\stackrel{\infty}{F} \\
\not\end{array}$ & 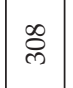 & \begin{tabular}{l|} 
\\
$\mathbb{H}$ \\
\end{tabular} & $\begin{array}{l}10 \\
\text { ○े } \\
0\end{array}$ & $\stackrel{\infty}{\grave{N}}$ & $\begin{array}{l}8 \\
8 \\
\& \\
⿱ 亠\end{array}$ & $\begin{array}{l}3 \\
\infty \\
\infty \\
\infty\end{array}$ & 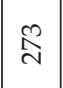 & $\begin{array}{l}\infty \\
\stackrel{\infty}{F} \\
F\end{array}$ \\
\hline \multirow{3}{*}{ 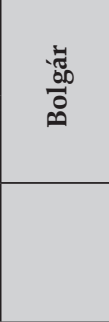 } & 湿 & Iี & $\mathbb{N}$ & $\underset{\infty}{+}$ & న̊ & F & छे & ? & $\infty$ & 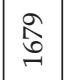 & 范 & $\stackrel{\infty}{\circledast}$ & $\delta$ & $\begin{array}{l}10 \\
\infty\end{array}$ & $\mathscr{7}$ & $\bar{\sigma}$ \\
\hline & 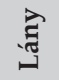 & ڤે & $\mathbb{6}$ & $\overrightarrow{\mathrm{D}}$ & $\stackrel{\infty}{\infty}$ & in & ळু & 总 & $\overrightarrow{\text { ल }}$ & $\begin{array}{l}\vec{n} \\
\stackrel{n}{n}\end{array}$ & $\tilde{S}$ & $\vec{m}$ & $\underset{\sim}{\stackrel{8}{0}}$ & స్ & $\underset{\sim}{\infty}$ & $\begin{array}{l}10 \\
10\end{array}$ \\
\hline & & 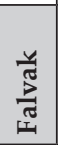 & 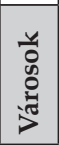 & 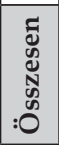 & 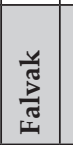 & 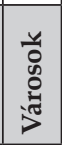 & 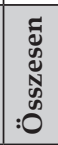 & $\mid$ & 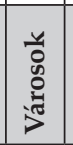 & \begin{tabular}{|l|}
$\tilde{u}$ \\
$\mathscr{W}$ \\
$\mathbb{N}$ \\
$: 0$ \\
$: 0$ \\
\end{tabular} & 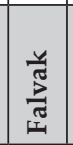 & 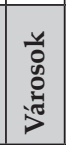 & 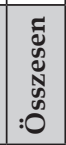 & 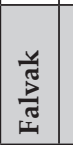 & 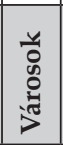 & 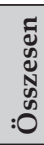 \\
\hline 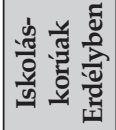 & & & รี & & & & & & శ్ & & & 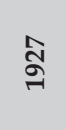 & & & 2 & \\
\hline
\end{tabular}




\begin{tabular}{|c|c|c|c|c|c|c|c|c|c|c|c|c|c|c|}
\hline $\begin{array}{l}\text { م } \\
\text { m } \\
\text { oे }\end{array}$ & 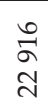 & $\begin{array}{l}\text { lo } \\
\text { N } \\
\text { N } \\
\text { nd }\end{array}$ & $\begin{array}{l}\infty \\
\text { హ} \\
\stackrel{\omega}{ }\end{array}$ & $\begin{array}{l}\infty \\
\infty \\
10 \\
10 \\
N\end{array}$ & $\begin{array}{l}0 \\
\text { in } \\
\text { Dी } \\
\text { ल }\end{array}$ & 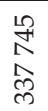 & 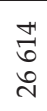 & 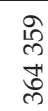 & $\begin{array}{l}\text { m } \\
\text { o } \\
\text { à } \\
\text { ch }\end{array}$ & $\begin{array}{l}m \\
\text { aू } \\
\text { ते }\end{array}$ & $\begin{array}{l}\text { I } \\
\text { م } \\
\infty \\
\infty \\
\infty\end{array}$ & 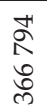 & $\begin{array}{l}\infty \\
\infty \\
\infty \\
\infty \\
\infty\end{array}$ & $\begin{array}{l}\text { त̂ } \\
\text { ूे } \\
\text { के }\end{array}$ \\
\hline \begin{tabular}{l}
$\infty$ \\
1 \\
10 \\
\multirow{1}{1}{} \\
\multirow{N}{N}{}
\end{tabular} & $\begin{array}{l}\stackrel{\curvearrowright}{\circ} \\
\infty \\
\sim\end{array}$ & $\begin{array}{l}\text { I } \\
\stackrel{1}{1} \\
\text { mิ }\end{array}$ & $\begin{array}{l}\text { ț } \\
\text { 1n } \\
\text { 苂 }\end{array}$ & $\begin{array}{l}\text { वे } \\
\text { సे }\end{array}$ & 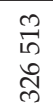 & 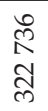 & $\begin{array}{l}\text { Fे } \\
\text { ते }\end{array}$ & $\begin{array}{l}\hat{N} \\
\hat{N} \\
\stackrel{1}{P} \\
\text { f }\end{array}$ & 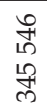 & 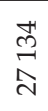 & $\begin{array}{l}0 \\
\infty \\
\mathbb{N} \\
\mathbb{N}\end{array}$ & $\begin{array}{l}10 \\
10 \\
10 \\
10 \\
n \\
m\end{array}$ & $\begin{array}{l}\infty \\
\infty \\
10 \\
\text { ND }\end{array}$ & 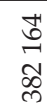 \\
\hline $\begin{array}{l}\vec{J} \\
\text { J } \\
\infty \\
\infty\end{array}$ & 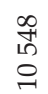 & $\begin{array}{l}\infty \\
\infty \\
\propto \\
\infty \\
+\end{array}$ & $\begin{array}{l}\vec{\Gamma} \\
\stackrel{ल}{ }\end{array}$ & $\begin{array}{l}\text { ㅇ } \\
\text { ని } \\
\text { ᄋ }\end{array}$ & $\begin{array}{l}\ddot{H} \\
\stackrel{8}{\circ}\end{array}$ & $\begin{array}{l}\text { 으 } \\
\text { م } \\
\text { ơ }\end{array}$ & $\begin{array}{l}\text { ুू } \\
\text { б }\end{array}$ & $\begin{array}{l}\text { న్ } \\
\text { } \\
\text { مे }\end{array}$ & $\begin{array}{l}\stackrel{\infty}{=} \\
\underset{F}{F}\end{array}$ & $\begin{array}{l}\stackrel{尺}{\circ} \\
\approx \\
\approx\end{array}$ & 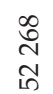 & $\begin{array}{l}\text { ڤे } \\
\text { ले } \\
\text { ले }\end{array}$ & $\begin{array}{l}\stackrel{+}{N} \\
\stackrel{\sim}{=}\end{array}$ & $\begin{array}{l}8 \\
8 \\
+ \\
0 \\
1\end{array}$ \\
\hline $\begin{array}{l}\mathcal{N} \\
\infty \\
10 \\
\infty\end{array}$ & 今ू & $\begin{array}{l}\stackrel{\text { oे }}{\text { N }} \\
\text { f }\end{array}$ & $\begin{array}{l}\stackrel{\infty}{N} \\
\stackrel{N}{N} \\
\text { N }\end{array}$ & $\stackrel{\circ}{\circ}$ & $\begin{array}{l}\infty \\
\delta \\
\delta \\
\delta\end{array}$ & $\begin{array}{l}\text { WH } \\
\infty \\
\infty \\
\infty\end{array}$ & $\begin{array}{l}\stackrel{0}{\circ} \\
\infty\end{array}$ & $\begin{array}{l}\text { 尺్ర } \\
\text { f }\end{array}$ & $\begin{array}{l}\text { ơ } \\
\text { ' } \\
\infty \\
\text { ल }\end{array}$ & ஜ̊ & $\begin{array}{l}\text { 尺ิ } \\
\text { fo } \\
\text { ff }\end{array}$ & $\begin{array}{l}\text { o } \\
\stackrel{+}{+} \\
\text { o }\end{array}$ & $\begin{array}{l}\infty \\
\text { ૂू }\end{array}$ & $\begin{array}{l}\text { f } \\
\text { I } \\
\text { If }\end{array}$ \\
\hline $\begin{array}{l}\overrightarrow{7} \\
\text { ल } \\
\stackrel{8}{\sigma}\end{array}$ & $\begin{array}{l}0 \\
\infty \\
\infty \\
\infty \\
\text { N }\end{array}$ & 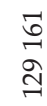 & $\begin{array}{l}\infty \\
\tilde{n} \\
10 \\
\sigma \\
\sigma\end{array}$ & $\begin{array}{l}\text { m } \\
\infty \\
\infty \\
\text { N }\end{array}$ & $\begin{array}{l}\Gamma \\
\infty \\
\text { సे }\end{array}$ & $\begin{array}{l}\stackrel{8}{8} \\
\text { 옹 }\end{array}$ & 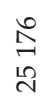 & 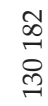 & \begin{tabular}{l} 
R \\
m \\
t' \\
\multirow{2}{*}{}
\end{tabular} & \begin{tabular}{l}
$\widetilde{\sigma}$ \\
\multirow{+}{\infty}{} \\
\multirow{2}{N}{}
\end{tabular} & $\begin{array}{l}\text { Nू } \\
\infty \\
\infty \\
\infty\end{array}$ & $\begin{array}{l}\text { ले } \\
\text { ते } \\
\text { ర్ }\end{array}$ & $\begin{array}{l}\stackrel{2}{\hat{N}} \\
\text { d }\end{array}$ & 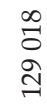 \\
\hline $\begin{array}{l}\text { J } \\
\text { Lू } \\
\text { L }\end{array}$ & $\begin{array}{l}\stackrel{ }{N} \\
\stackrel{2}{N}\end{array}$ & $\begin{array}{l}\text { J্ర } \\
\text { I }\end{array}$ & $\begin{array}{l}\text { హु } \\
\text { 人⿱ }\end{array}$ & $\begin{array}{l}\bar{\alpha} \\
\stackrel{\alpha}{\alpha}\end{array}$ & 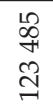 & \begin{tabular}{l}
$\infty$ \\
\multirow{4}{*}{} \\
8
\end{tabular} & \begin{tabular}{l}
$\mathbb{H}$ \\
N \\
\multirow{N}{*}{}
\end{tabular} & 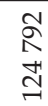 & $\begin{array}{l}\text { ma } \\
\text { ă }\end{array}$ & \begin{tabular}{l}
$\infty$ \\
in \\
\multirow{N}{N}{}
\end{tabular} & 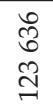 & $\begin{array}{l}\text { 乃 } \\
\text { N } \\
\text { م }\end{array}$ & \begin{tabular}{l}
$\infty$ \\
$\infty$ \\
$\infty$ \\
\multirow{N}{N}{}
\end{tabular} & $\begin{array}{l}\bar{N} \\
\text { I } \\
\text { Na }\end{array}$ \\
\hline రై & $\stackrel{\widehat{N}}{\stackrel{\infty}{\infty}}$ & 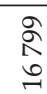 & 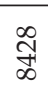 & $\begin{array}{l}\infty \\
\infty \\
\infty\end{array}$ & $\begin{array}{l}\text { ते } \\
\stackrel{N}{N}\end{array}$ & $\begin{array}{l}\text { ळे } \\
\text { ळ) }\end{array}$ & 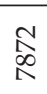 & \begin{tabular}{l}
$\infty$ \\
\multirow{2}{*}{} \\
$\sigma$
\end{tabular} & $\begin{array}{l}\hat{1} \\
\stackrel{1}{\infty}\end{array}$ & $\begin{array}{l}\infty \\
\infty \\
\infty \\
\infty\end{array}$ & 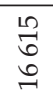 & ๖ి & $\begin{array}{l}\overrightarrow{0} \\
\stackrel{\infty}{\infty}\end{array}$ & $\begin{array}{l}\text { న్ } \\
\text { o } \\
0\end{array}$ \\
\hline 阁 & $\underset{\infty}{\vec{\Xi}}$ & 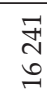 & 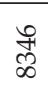 & 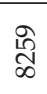 & $\begin{array}{l}\text { 이 } \\
0 \\
0\end{array}$ & $\underset{\infty}{\mathbb{N}}$ & 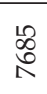 & $\begin{array}{l}\text { సे } \\
12\end{array}$ & $\underset{\Im}{\overparen{\Im}}$ & $\stackrel{+}{\stackrel{R}{R}}$ & $\begin{array}{l}\stackrel{1}{\mathfrak{I}} \\
6 \\
\sigma\end{array}$ & $\underset{\infty}{\infty}$ & $\underset{\infty}{\stackrel{\Xi}{Z}}$ & 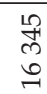 \\
\hline 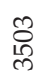 & 옴 & $\begin{array}{l}\text { [n } \\
\text { D } \\
\text { D }\end{array}$ & $\underset{\infty}{\mathbb{N}}$ & $\stackrel{\infty}{\widetilde{N}}$ & $\begin{array}{l}\text { 오 } \\
\text { 아 }\end{array}$ & 党 & હે & बे & શิ & $\stackrel{\circ}{\curvearrowright}$ & 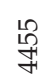 & 今ึ & $\stackrel{\widehat{\sigma}}{\circ}$ & $\begin{array}{l}\text { F } \\
\text { 吕 }\end{array}$ \\
\hline $\begin{array}{l}\text { त } \\
\stackrel{n}{n}\end{array}$ & 名 & 今ે & 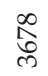 & ถి & $\begin{array}{l}\widehat{N} \\
\infty \\
\infty\end{array}$ & $\vec{\nabla}$ & $\stackrel{\infty}{\circ}$ & $\stackrel{\hat{N}}{\stackrel{0}{0}}$ & $\begin{array}{l}20 \\
\infty \\
\infty\end{array}$ & $\stackrel{g}{q}$ & 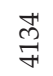 & 太ু & $\stackrel{\vartheta}{ح}$ & $\underset{\gamma}{\mathscr{\gamma}}$ \\
\hline $\begin{array}{l}\text { ले } \\
\text { ल) }\end{array}$ & ले & స్ & $\begin{array}{l}\text { N } \\
\text { n}\end{array}$ & $\stackrel{\llcorner}{\infty}$ & $\underset{\text { Ff }}{F}$ & 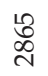 & $\widehat{\widehat{~}}$ & 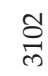 & $\stackrel{\vec{N}}{\stackrel{n}{n}}$ & $\begin{array}{l}\infty \\
\stackrel{\sim}{N}\end{array}$ & 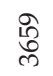 & $\begin{array}{l}\overline{0} \\
\stackrel{0}{0}\end{array}$ & $\overline{\widehat{స}}$ & నิ \\
\hline$\underset{\text { f }}{\stackrel{\infty}{n}}$ & $\begin{array}{l}\infty \\
\stackrel{N}{N}\end{array}$ & $\underset{\text { Nి }}{\mathbb{N}}$ & $\begin{array}{l}\hat{\text { సे }} \\
\text { ते }\end{array}$ & \& & $\begin{array}{l}\text { त్ } \\
\text { లె }\end{array}$ & $\begin{array}{l}\stackrel{10}{\circ} \\
\text { הิ }\end{array}$ & ڤે & సิ & 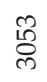 & 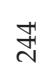 & 今े & 옷 & $\stackrel{\mathscr{N}}{\sim}$ & ণ্ \\
\hline 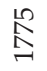 & F & $\begin{array}{l}0 \\
\infty \\
-\infty\end{array}$ & ঞ̊ & ৯े & 会 & ఫু & సे & হু & ळू & ন & శু & $\bar{\infty}$ & ন & $\frac{10}{\sigma}$ \\
\hline$\stackrel{\hat{\Omega}}{\stackrel{2}{2}}$ & $\mathbb{N}$ & $\vec{尺}$ & ๙్ & $\triangleq$ & אু & $\bar{\alpha}$ & $\exists$ & శૈ & $\stackrel{\infty}{\infty}$ & $\vec{\sim}$ & \&̊ & ఫర & $\approx$ & $\underset{\infty}{\infty}$ \\
\hline $\begin{array}{l}\frac{y}{\pi} \\
\frac{\pi}{\pi}\end{array}$ & 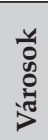 & 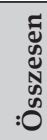 & 尝 & 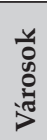 & $\begin{array}{l}\tilde{D} \\
\text { है } \\
\text { W } \\
: 0\end{array}$ & $\begin{array}{l}\frac{y}{\pi} \\
\frac{2}{\pi}\end{array}$ & 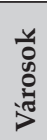 & $\begin{array}{l} \\
\text { Dू } \\
\text { N } \\
\text { : }\end{array}$ & $\begin{array}{l}\frac{y}{\pi} \\
\text { हु }\end{array}$ & 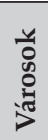 & 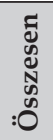 & 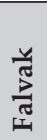 & 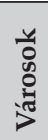 & 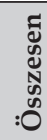 \\
\hline & సે & & & बू & & & $\stackrel{\mathscr{\sigma}}{\sigma}$ & & & ふొ & & & ڤิ & \\
\hline
\end{tabular}


3. Az erdélyi iskoláskorúak nemzetiségi megoszlása falvakon és városokon:

\begin{tabular}{|c|c|c|c|c|c|c|c|c|}
\hline \multirow{2}{*}{\multicolumn{2}{|c|}{$\begin{array}{l}\text { Iskoláskorúak } \\
\text { Erdélyben }\end{array}$}} & \multicolumn{3}{|c|}{$\begin{array}{l}\text { Összesen román, magyar, } \\
\text { német, zsidó, ukrán szerb, } \\
\text { bolgár }\end{array}$} & \multirow{2}{*}{$\begin{array}{l}\text { Egyéb } \\
\text { fiú és } \\
\text { lány }\end{array}$} & \multicolumn{3}{|c|}{ Összesen } \\
\hline & & Fiú & Lány & Összesen & & Fiú & Lány & Összesen \\
\hline \multirow{3}{*}{1924} & Falvak & 318919 & \begin{tabular}{|l|}
303849 \\
\end{tabular} & 622768 & 9631 & 323619 & 308780 & 632399 \\
\hline & Városok & 57767 & 52562 & 10329 & 1342 & 58526 & 53145 & 111671 \\
\hline & Összesen & 376686 & \begin{tabular}{|l|}
356411 \\
\end{tabular} & 33097 & 10973 & 82145 & 361925 & 74 \\
\hline \multirow{3}{*}{1925} & & 860 & 461 & 47939 & 13882 & 493042 & 468779 & \\
\hline & Városok & 71967 & 67231 & 139198 & 1971 & 73004 & 68165 & 141169 \\
\hline & Öss & 558045 & 529 & 7137 & 15853 & 566046 & 44 & \\
\hline \multirow{3}{*}{1926} & Falvak & 462785 & 441812 & 4597 & 13733 & 469765 & 448 & 30 \\
\hline & Vá1 & 1 & & & & & & \\
\hline & Össze & 532906 & 504760 & 1037666 & 15447 & 540794 & 512 & 1053113 \\
\hline \multirow{3}{*}{1927} & & & & & & & & \\
\hline & Város & 73296 & 6 & 296 & 16 & 74 & 63756 & 40 \\
\hline & & & & & & & & \\
\hline \multirow{3}{*}{1928} & Falvak & 469162 & 445 & 26 & 12632 & 475699 & 451 & 58 \\
\hline & & & & 348 & 1267 & 75707 & & \\
\hline & Össz & 544198 & 509476 & 3674 & 13899 & 551406 & 516167 & 10 \\
\hline \multirow{3}{*}{1929} & & & & & 10767 & & & \\
\hline & Várc & 71579 & 67 & 546 & 1101 & 72152 & 61495 & 133647 \\
\hline & Össze & 536155 & 503790 & 1039945 & & & 509 & 1051 \\
\hline \multirow{3}{*}{1931} & & 477499 & 455 & 736 & 15448 & 485318 & 462866 & 948184 \\
\hline & Város & & & & & & 66 & 04 \\
\hline & Össz & 205 & 520645 & 1850 & 16838 & 559772 & 528916 & 1088688 \\
\hline \multirow{3}{*}{1933} & Falvak & 499636 & 477579 & 77215 & 17260 & 508453 & 486022 & 994475 \\
\hline & Városok & 70127 & 64222 & 134349 & 1362 & 70851 & 64860 & 135711 \\
\hline & Összese & 569763 & 541801 & 1111564 & 18622 & 579304 & 550882 & 1130186 \\
\hline \multirow{3}{*}{1936} & Falvak & 521747 & \begin{tabular}{|l|}
499671 \\
\end{tabular} & 1021418 & 19743 & 531847 & 509314 & 1041161 \\
\hline & \begin{tabular}{|l|} 
Városok \\
\end{tabular} & 76011 & 68788 & 144799 & 1801 & 76952 & 69648 & 146600 \\
\hline & Összese & 597758 & 568459 & 1166217 & 21544 & 608799 & 578962 & 1187761 \\
\hline \multirow{3}{*}{1937} & Falvak & 525197 & 502975 & 1028172 & 20030 & 535376 & 512826 & 1048202 \\
\hline & \begin{tabular}{|l|} 
Városok \\
\end{tabular} & 80164 & 71361 & 151525 & 1989 & 81215 & 72299 & 153514 \\
\hline & Összesen & 605361 & 574336 & 1179697 & 22019 & 616591 & 585125 & 1201716 \\
\hline
\end{tabular}


4. Az állami óvodák száma az erdélyi falvakban és városokon:

\begin{tabular}{|c|c|c|}
\hline \multicolumn{2}{|c|}{ Állami óvodák Erdélyben } & \multirow{2}{*}{$\begin{array}{c}\text { Intézmények száma } \\
50\end{array}$} \\
\hline \multirow{3}{*}{ 1921/1922 } & Falvak & \\
\hline & Városok & 49 \\
\hline & Összesen & 99 \\
\hline \multirow{3}{*}{$1922 / 1923$} & Falvak & 50 \\
\hline & \begin{tabular}{|l|} 
Városok \\
\end{tabular} & 75 \\
\hline & Összesen & 125 \\
\hline \multirow{3}{*}{ 1923/1924 } & Falvak & 110 \\
\hline & \begin{tabular}{|l|} 
Városok \\
\end{tabular} & 63 \\
\hline & \begin{tabular}{|l|} 
Összesen \\
\end{tabular} & 173 \\
\hline \multirow{3}{*}{$1924 / 1925$} & Falvak & 142 \\
\hline & Városok & 66 \\
\hline & Összesen & 208 \\
\hline \multirow{3}{*}{$1925 / 1926$} & Falvak & 203 \\
\hline & \begin{tabular}{|l|} 
Városok \\
\end{tabular} & 108 \\
\hline & Összesen & 311 \\
\hline \multirow{3}{*}{$1926 / 1927$} & Falvak & 258 \\
\hline & \begin{tabular}{|l|} 
Városok \\
\end{tabular} & 100 \\
\hline & \begin{tabular}{|l|} 
Összesen \\
\end{tabular} & 358 \\
\hline \multirow{3}{*}{$1927 / 1928$} & Falvak & 365 \\
\hline & Városok & 122 \\
\hline & Összesen & 487 \\
\hline \multirow{3}{*}{$1928 / 1929$} & \begin{tabular}{|l|} 
Falvak \\
\end{tabular} & 436 \\
\hline & \begin{tabular}{|l|} 
Városok \\
\end{tabular} & 120 \\
\hline & Összesen & 556 \\
\hline \multirow{3}{*}{ 1930/1931 } & Falvak & 538 \\
\hline & \begin{tabular}{|l|} 
Városok \\
\end{tabular} & 135 \\
\hline & Összesen & 673 \\
\hline \multirow{3}{*}{ 1931/1932 } & Falvak & 542 \\
\hline & \begin{tabular}{|l|} 
Városok \\
\end{tabular} & 133 \\
\hline & Összesen & 675 \\
\hline \multirow{3}{*}{$1932 / 1933$} & Falvak & 519 \\
\hline & \begin{tabular}{|l|} 
Városok \\
\end{tabular} & 147 \\
\hline & Összesen & 666 \\
\hline \multirow{3}{*}{$1935 / 1936$} & Falvak & 599 \\
\hline & Városok & 164 \\
\hline & Összesen & 763 \\
\hline \multirow{3}{*}{$1936 / 1937$} & Falvak & 642 \\
\hline & Városok & 165 \\
\hline & Összesen & 807 \\
\hline
\end{tabular}


5. Az állami elemi iskolák és tanerőik száma az erdélyi falvakban és városokon:

\begin{tabular}{|c|c|c|c|c|c|c|}
\hline \multirow{2}{*}{\multicolumn{2}{|c|}{$\begin{array}{l}\text { Állami elemi iskolák } \\
\text { Erdélyben }\end{array}$}} & \multicolumn{4}{|c|}{ Intézmények száma } & \multirow{2}{*}{$\begin{array}{c}\text { Tanerők } \\
\text { száma }\end{array}$} \\
\hline & & Fiú & Lány & Vegyes & Összesen & \\
\hline \multirow{3}{*}{ 1921/1922 } & Falvak & 37 & 47 & 2689 & 2773 & 4717 \\
\hline & Városok & 23 & 24 & 224 & 271 & 1150 \\
\hline & Összesen & 60 & 71 & 2913 & 3044 & 5867 \\
\hline \multirow{3}{*}{$1922 / 1923$} & Falvak & - & - & 3391 & 3391 & 4950 \\
\hline & Városok & 17 & 18 & 189 & 224 & 978 \\
\hline & Összesen & 17 & 18 & 3580 & 3615 & 5928 \\
\hline \multirow{3}{*}{$1923 / 1924$} & Falvak & - & - & 3545 & 3545 & 5158 \\
\hline & Városok & 10 & 8 & 128 & 146 & 890 \\
\hline & Összesen & 10 & 8 & 3673 & 3691 & 6048 \\
\hline \multirow{3}{*}{$1924 / 1925$} & Falvak & 2 & 1 & 3600 & 3603 & 5995 \\
\hline & Városok & 12 & 10 & 124 & 146 & 928 \\
\hline & Összesen & 14 & 11 & 3724 & 3749 & 6923 \\
\hline \multirow{3}{*}{$1925 / 1926$} & Falvak & 6 & 6 & 3548 & 3560 & 6327 \\
\hline & Városok & 15 & 13 & 132 & 160 & 1133 \\
\hline & Összesen & 21 & 19 & 3680 & 3720 & 7460 \\
\hline \multirow{3}{*}{$1926 / 1927$} & Falvak & 4 & 4 & 3695 & 3703 & 6828 \\
\hline & Városok & 13 & 13 & 115 & 141 & 946 \\
\hline & Összesen & 17 & 17 & 3810 & 3844 & 7774 \\
\hline \multirow{3}{*}{$1927 / 1928$} & Falvak & 5 & 3 & 3818 & 3826 & 7342 \\
\hline & Városok & 15 & 13 & 132 & 160 & 968 \\
\hline & Összesen & 20 & 16 & 3950 & 3986 & 8310 \\
\hline \multirow{3}{*}{$1928 / 1929$} & Falvak & 3 & 2 & 4155 & 4160 & 7496 \\
\hline & Városok & 16 & 15 & 137 & 168 & 1202 \\
\hline & Összesen & 19 & 17 & 4292 & 4328 & 8698 \\
\hline \multirow{3}{*}{$1929 / 1930$} & Falvak & & & & 4046 & 7815 \\
\hline & Városok & & & & 181 & 1061 \\
\hline & Összesen & & & & 4227 & 8876 \\
\hline \multirow{3}{*}{$1930 / 1931$} & Falvak & 2 & 2 & 4075 & 4079 & 7891 \\
\hline & Városok & 14 & 14 & 153 & 182 & 1052 \\
\hline & Összesen & 16 & 16 & 4228 & 4261 & 8943 \\
\hline \multirow{3}{*}{$1931 / 1932$} & Falvak & 5 & 3 & 4092 & 4100 & 7826 \\
\hline & Városok & 15 & 14 & 156 & 185 & 1202 \\
\hline & Összesen & 20 & 17 & 4248 & 4285 & 9028 \\
\hline \multirow{3}{*}{$1932 / 1933$} & Falvak & 2 & 1 & 4107 & 4110 & 7903 \\
\hline & Városok & 11 & 14 & 162 & 187 & 1169 \\
\hline & Összesen & 13 & 15 & 4269 & 4297 & 9072 \\
\hline \multirow{3}{*}{$1935 / 1936$} & Falvak & 2 & - & 4287 & 4289 & 8954 \\
\hline & Városok & 18 & 16 & 181 & 215 & 1241 \\
\hline & Összesen & 20 & 16 & 4468 & 4504 & 10195 \\
\hline
\end{tabular}




\begin{tabular}{|c|l|c|c|c|c|c|}
\hline \multirow{3}{*}{$\mathbf{1 9 3 6 / 1 9 3 7}$} & Falvak & 1 & 2 & 4337 & 4340 & 9850 \\
\cline { 2 - 7 } & Városok & 28 & 25 & 177 & 230 & 1410 \\
\cline { 2 - 7 } & Összesen & 29 & 27 & 4514 & 4570 & 11260 \\
\hline
\end{tabular}

6. Az erdélyi állami tanitó- és tanitónóképzók diákjai és tanárai:

\begin{tabular}{|c|c|c|c|c|c|c|}
\hline \multirow{2}{*}{\multicolumn{2}{|c|}{$\begin{array}{l}\text { Állami tanító- és tanítónő- } \\
\text { képzők Erdélyben }\end{array}$}} & \multirow{3}{*}{$\begin{array}{c}\begin{array}{c}\text { Iskolák } \\
\text { száma }\end{array} \\
9\end{array}$} & \multicolumn{3}{|c|}{ Tanulók } & \multirow{3}{*}{$\begin{array}{c}\begin{array}{c}\text { Tanárok } \\
\text { (mes- } \\
\text { terek } \\
\text { nélkül) }\end{array} \\
99\end{array}$} \\
\hline & & & \multirow{2}{*}{$\begin{array}{c}\text { Beiratkozottak } \\
1445\end{array}$} & \multicolumn{2}{|c|}{$\begin{array}{l}\text { Felsőbb osztály- } \\
\text { ba léptek }\end{array}$} & \\
\hline \multirow{3}{*}{ 1921/1922 } & Tanítóképzők & & & 1260 & 87,2 & \\
\hline & Tanítónőképzők & 7 & 1321 & 1129 & 85,5 & 49 \\
\hline & Összesen & 16 & 2766 & 2389 & 86,4 & 148 \\
\hline \multirow{3}{*}{$1922 / 1923$} & Tanítóképzők & 9 & 1823 & 1547 & 84,9 & 97 \\
\hline & Tanítónőképzők & 8 & 1652 & 1403 & 84,9 & 61 \\
\hline & Összesen & 17 & 3475 & 2950 & 84,9 & 158 \\
\hline \multirow{3}{*}{$1923 / 1924$} & Tanítóképzők & 13 & 2338 & 2033 & 87,0 & 128 \\
\hline & \begin{tabular}{|l|} 
Tanítónőképzők \\
\end{tabular} & 9 & 1807 & 1606 & 88,9 & 70 \\
\hline & \begin{tabular}{|l|} 
Összesen \\
\end{tabular} & 22 & 4145 & 3639 & 87,8 & 198 \\
\hline \multirow{3}{*}{$1924 / 1925$} & Tanítóképzők & 15 & 3039 & 2588 & 85,2 & 146 \\
\hline & \begin{tabular}{|l|} 
Tanítónőképzők \\
\end{tabular} & 10 & 1888 & 1705 & 90,3 & 88 \\
\hline & \begin{tabular}{|l|} 
Összesen \\
\end{tabular} & 25 & 4927 & 4293 & 87,1 & 234 \\
\hline \multirow{3}{*}{$1925 / 1926$} & Tanítóképzők & 15 & 3373 & 2844 & 84,3 & 152 \\
\hline & \begin{tabular}{|l|} 
Tanítónőképzők \\
\end{tabular} & 10 & 1935 & 1686 & 87,1 & 82 \\
\hline & \begin{tabular}{|l|} 
Összesen \\
\end{tabular} & 25 & 5308 & 4530 & 85,3 & 234 \\
\hline \multirow{3}{*}{$1926 / 1927$} & Tanítóképzők & 15 & 3557 & 3079 & 86,6 & 160 \\
\hline & \begin{tabular}{|l|} 
Tanítónőképzők \\
\end{tabular} & 10 & 1972 & 1677 & 85,0 & 96 \\
\hline & \begin{tabular}{|l|} 
Összesen \\
\end{tabular} & 25 & 5529 & 4756 & 86,0 & 256 \\
\hline \multirow{3}{*}{$1927 / 1928$} & Tanítóképzők & 18 & 4113 & 3536 & 86,0 & 177 \\
\hline & Tanítónőképzők & 12 & 2413 & 2056 & 85,2 & 114 \\
\hline & \begin{tabular}{|l|} 
Összesen \\
\end{tabular} & 30 & 6526 & 5592 & 85,7 & 291 \\
\hline \multirow{3}{*}{$1928 / 1929$} & \begin{tabular}{|l|} 
Tanítóképzők \\
\end{tabular} & 18 & 4018 & 3453 & 85,9 & 189 \\
\hline & Tanítónőképzők & 12 & 2319 & 2061 & 88,9 & 128 \\
\hline & \begin{tabular}{|l|} 
Összesen \\
\end{tabular} & 30 & 6337 & 5514 & 87,0 & 317 \\
\hline \multirow{3}{*}{ 1930/1931 } & Tanítóképzők & 17 & 3117 & 2670 & 85,7 & 161 \\
\hline & Tanítónőképzők & 12 & 2068 & 1789 & 86,5 & 213 \\
\hline & \begin{tabular}{|l|} 
Összesen \\
\end{tabular} & 29 & 5185 & 4459 & 86,0 & 374 \\
\hline \multirow{3}{*}{ 1931/1932 } & Tanítóképzők & 17 & 2779 & 2473 & 89,0 & 269 \\
\hline & Tanítónőképzők & 11 & 1670 & 1514 & 90,7 & 201 \\
\hline & \begin{tabular}{|l|} 
Összesen \\
\end{tabular} & 28 & 4449 & 3987 & 89,6 & 470 \\
\hline \multirow{3}{*}{$1932 / 1933$} & Tanítóképzők & 16 & 2313 & 2077 & 89,8 & 251 \\
\hline & \begin{tabular}{|l|} 
Tanítónőképzők \\
\end{tabular} & 9 & 1498 & 1326 & 88,5 & 161 \\
\hline & Összesen & 25 & 3811 & 3403 & 89,3 & 412 \\
\hline
\end{tabular}




\begin{tabular}{|l|l|c|c|c|c|c|}
\hline \multirow{3}{*}{ 1935/1936 } & Tanítóképzők & 16 & 2870 & 2500 & 87,1 & 266 \\
\cline { 2 - 7 } & Tanítónőképzők & 9 & 1856 & 1615 & 87,0 & 167 \\
\cline { 2 - 7 } & Összesen & 25 & 4726 & 4115 & 87,1 & 433 \\
\hline \multirow{3}{*}{ 1936/1937 } & Tanítóképzők & 17 & 2954 & 2596 & 87,9 & 277 \\
\cline { 2 - 7 } & Tanítónőképzők & 9 & 1906 & 1670 & 87,6 & 168 \\
\cline { 2 - 7 } & Összesen & 26 & 4860 & 4266 & 87,8 & 445 \\
\hline
\end{tabular}

7. Az erdélyi állami tanitó- és tanítónóképzók diákjainak nemzetiségi megoszlása:

\begin{tabular}{|c|c|c|c|c|c|c|c|c|c|c|c|c|}
\hline \multirow{2}{*}{\multicolumn{2}{|c|}{$\begin{array}{c}\text { Állami tanítóképzők } \\
\text { diákjainak nemzetiségi } \\
\text { megoszlása }\end{array}$}} & \multicolumn{11}{|c|}{ A beiratkozott diákok nemzetisége } \\
\hline & & \multicolumn{2}{|c|}{ 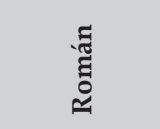 } & \multicolumn{2}{|c|}{ 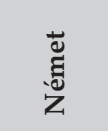 } & \multicolumn{2}{|c|}{ 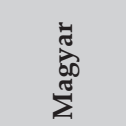 } & \multicolumn{2}{|c|}{$\begin{array}{l}\text { :⿱乛龰⿱二厶 } \\
\text { N }\end{array}$} & \multicolumn{2}{|c|}{ 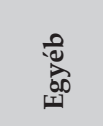 } & \multirow{2}{*}{ 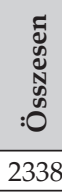 } \\
\hline \multirow{3}{*}{$1923 / 1924$} & Tanítóképzők & 2159 & 92,3 & 6 & 0,3 & 170 & 7,3 & - & & 3 & 0,1 & \\
\hline & Tanítónőképzők & 1774 & 98,2 & 5 & 0,3 & 19 & 1,1 & 9 & 0,5 & - & & 1807 \\
\hline & Összesen & 3933 & 94,9 & 11 & 0,3 & 189 & 4,6 & 9 & 0,2 & 3 & 0,1 & 4145 \\
\hline \multirow{3}{*}{$1924 / 1925$} & Tanítóképzők & 2827 & 93,0 & 31 & 1,0 & 172 & 5,7 & 2 & 0,1 & 7 & 0,2 & 3039 \\
\hline & Tanítónőképzők & 1845 & 97,7 & 4 & 0,2 & 27 & 1,4 & 12 & 0,6 & - & - & 1888 \\
\hline & Összesen & 4672 & 94,8 & 35 & 0,7 & 199 & 4,0 & 14 & 0,3 & 7 & 0,1 & 4927 \\
\hline \multirow{3}{*}{$1925 / 1926$} & Tanítóképzők & 3198 & 94,8 & 25 & 0,7 & 127 & 3,8 & - & 0,0 & 23 & 0,7 & 3373 \\
\hline & Tanítónőképzők & 1880 & 97,2 & 9 & 0,5 & 22 & 1,1 & 12 & 0,6 & 12 & 0,6 & 1935 \\
\hline & Összesen & 5078 & 95,7 & 34 & 0,6 & 149 & 2,8 & 12 & 0,2 & 35 & 0,7 & 5308 \\
\hline \multirow{3}{*}{ 1926/1927 } & Tanítóképzők & 3430 & 96,4 & 18 & 0,5 & 91 & 2,6 & 1 & 0,0 & 17 & 0,5 & 3557 \\
\hline & Tanítónőképzők & 1909 & 96,8 & 10 & 0,5 & 34 & 1,7 & 10 & 0,5 & 9 & 0,5 & 1972 \\
\hline & \begin{tabular}{|l|l|} 
Összesen \\
\end{tabular} & 5339 & 96,6 & 28 & 0,5 & 125 & 2,3 & 11 & 0,2 & 26 & 0,5 & 5529 \\
\hline \multirow{3}{*}{$1927 / 1928$} & Tanítóképzők & 3976 & 96,7 & 15 & 0,4 & 100 & 2,4 & 1 & 0,0 & 21 & 0,5 & 4113 \\
\hline & Tanítónőképzők & 2303 & 95,4 & 9 & 0,4 & 77 & 3,2 & 11 & 0,5 & 13 & 0,5 & 2413 \\
\hline & Összesen & 6279 & 96,2 & 24 & 0,4 & 177 & 2,7 & 12 & 0,2 & 34 & 0,5 & 6526 \\
\hline \multirow{3}{*}{ 1928/1929 } & Tanítóképzők & 3898 & 97,0 & 25 & 0,6 & 73 & 1,8 & 1 & 0,0 & 21 & 0,5 & 4018 \\
\hline & Tanítónőképzők & 2204 & 95,0 & 20 & 0,9 & 69 & 3,0 & 10 & 0,4 & 16 & 0,7 & 2319 \\
\hline & Összesen & 6102 & 96,3 & 45 & 0,7 & 142 & 2,2 & 11 & 0,2 & 37 & 0,6 & 6337 \\
\hline \multirow{3}{*}{$1935 / 1936$} & Tanítóképzők & 2682 & 93,4 & 41 & 1,4 & 94 & 3,3 & 6 & 0,2 & 47 & 1,6 & 2870 \\
\hline & Tanítónőképzők & 1712 & 92,2 & 17 & 0,9 & 108 & 5,8 & 11 & 0,6 & 8 & 0,4 & 1856 \\
\hline & Összesen & 4394 & 93,0 & 58 & 1,2 & 202 & 4,3 & 17 & 0,4 & 55 & 1,2 & 4726 \\
\hline \multirow{3}{*}{$1936 / 1937$} & Tanítóképzők & 2737 & 92,7 & 60 & 2,0 & 108 & 3,7 & 5 & 0,2 & 44 & 1,5 & 2954 \\
\hline & Tanítónőképzők & 1789 & 93,9 & 19 & 1,0 & 80 & 4,2 & 4 & 0,2 & 14 & 0,7 & 1906 \\
\hline & Összesen & 4526 & 93,1 & 79 & 1,6 & 188 & 3,9 & 9 & 0,2 & 58 & 1,2 & 4860 \\
\hline
\end{tabular}


8. Az erdélyi állami tanító- és tanitónőképzók diákjainak vallási megoszlása:

\begin{tabular}{|c|c|c|c|c|c|c|c|c|c|c|}
\hline \multirow{2}{*}{\multicolumn{2}{|c|}{$\begin{array}{c}\text { Állami tanító- és tanítónő- } \\
\text { képzők }\end{array}$}} & \multicolumn{9}{|c|}{ A beiratkozottak vallása } \\
\hline & & \multirow{2}{*}{ 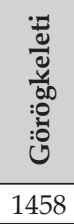 } & \multirow{2}{*}{ 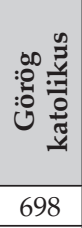 } & \multirow{2}{*}{ 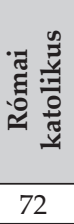 } & \multirow{2}{*}{ 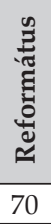 } & \multirow{2}{*}{ 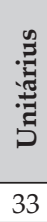 } & \multirow{2}{*}{ 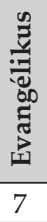 } & \multirow{2}{*}{ 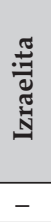 } & \multirow{2}{*}{$\begin{array}{l}\text { है } \\
\sum_{10}^{00} \\
-\end{array}$} & \multirow{2}{*}{ 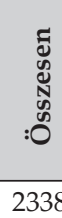 } \\
\hline \multirow{3}{*}{ 1923/1924 } & Tanítóképzők & & & & & & & & & \\
\hline & Tanítónőképzők & 1367 & 390 & 29 & 6 & 1 & 4 & 9 & 1 & 1807 \\
\hline & Összesen & 2825 & 1088 & 101 & 76 & 34 & 11 & 9 & 1 & 4145 \\
\hline \multirow{3}{*}{$1924 / 1925$} & Tanítóképzők & 2074 & 750 & 99 & 67 & 39 & 7 & 2 & 1 & 3039 \\
\hline & Tanítónőképzők & 1401 & 433 & 26 & 11 & - & 3 & 12 & 2 & 1888 \\
\hline & Összesen & 3475 & 1183 & 125 & 78 & 39 & 10 & 14 & 3 & 4927 \\
\hline \multirow{3}{*}{$1925 / 1926$} & Tanítóképzők & 2343 & 870 & 71 & 58 & 27 & 4 & - & - & 3373 \\
\hline & Tanítónőképzők & 1431 & 449 & 28 & 11 & - & 1 & 12 & 3 & 1935 \\
\hline & Összes & 3774 & 1319 & 99 & 69 & 27 & 5 & 12 & 3 & 5308 \\
\hline \multirow{3}{*}{ 1926/1927 } & Tanítóképzők & 2601 & 836 & 57 & 37 & 21 & 4 & 1 & - & 3557 \\
\hline & Tanítónőképzők & 1411 & 496 & 38 & 14 & - & 2 & 10 & 1 & 1972 \\
\hline & Összesen & 4012 & 1332 & 95 & 51 & 21 & 6 & 11 & 1 & 5529 \\
\hline \multirow{3}{*}{$1927 / 1928$} & Tanító & 2772 & 1217 & 63 & 39 & 17 & 4 & 1 & - & 4113 \\
\hline & Tanítónőképzők & 1594 & 714 & 49 & 29 & 6 & 6 & 11 & 4 & 2413 \\
\hline & Össze & 4366 & 1931 & 112 & 68 & 23 & 10 & 12 & 4 & 6526 \\
\hline \multirow{3}{*}{ 1928/1929 } & Tanítóképzők & 2668 & 1248 & 53 & 33 & 13 & 2 & 1 & - & 4018 \\
\hline & Tanítónőképzők & 1513 & 689 & 62 & 38 & 4 & - & 10 & 3 & 2319 \\
\hline & Összesen & 4181 & 1937 & 115 & 71 & 17 & 2 & 11 & 3 & 6337 \\
\hline \multirow{3}{*}{ 1930/1931 } & Tanítóképzők & 1816 & 1169 & 99 & 30 & 12 & 9 & 1 & - & 3117 \\
\hline & Tanítónőképzők & 1270 & 661 & 89 & 31 & 5 & 3 & 7 & 1 & 2068 \\
\hline & Összesen & 3086 & 1830 & 188 & 61 & 17 & 12 & 8 & 1 & 5185 \\
\hline \multirow{3}{*}{ 1931/1932 } & Tanítóképzők & 1705 & 951 & 71 & 23 & 16 & 12 & 1 & - & 2779 \\
\hline & Tanítónőképzők & 1056 & 517 & 61 & 21 & 4 & 2 & 9 & - & 1670 \\
\hline & Összesen & 2761 & 1468 & 132 & 44 & 20 & 14 & 10 & - & 4449 \\
\hline \multirow{3}{*}{$1932 / 1933$} & Tanítóképzők & 1446 & 736 & 72 & 29 & 12 & 15 & 3 & - & 2313 \\
\hline & Tanítónőképzők & 914 & 467 & 63 & 37 & 5 & 3 & 9 & - & 1498 \\
\hline & Összesen & 2360 & 1203 & 135 & 66 & 17 & 18 & 12 & - & 3811 \\
\hline \multirow{3}{*}{$1935 / 1936$} & Tanítóképzők & 1617 & 1074 & 99 & 42 & 22 & 9 & 6 & 1 & 2870 \\
\hline & Tanítónőképzők & 1102 & 609 & 76 & 38 & 12 & 5 & 13 & 1 & 1856 \\
\hline & Összesen & 2719 & 1683 & 175 & 80 & 34 & 14 & 19 & 2 & 4726 \\
\hline \multirow{3}{*}{$1936 / 1937$} & Tanítóképzők & 1622 & 1134 & 119 & 43 & 17 & 10 & 1 & 8 & 2954 \\
\hline & Tanítónőképzők & 1139 & 650 & 58 & 35 & 9 & 6 & 6 & 3 & 1906 \\
\hline & Összesen & 2761 & 1784 & 177 & 78 & 26 & 16 & 7 & 11 & 4860 \\
\hline
\end{tabular}


9. Az erdélyi állami tanitó- és tanitónóképzők diákjainak vallási megoszlása, százalékban kifejezve:

\begin{tabular}{|c|c|c|c|c|c|c|c|c|c|}
\hline \multirow{2}{*}{\multicolumn{2}{|c|}{$\begin{array}{c}\text { Állami tanító- és tanítónő- } \\
\text { képzők }\end{array}$}} & \multicolumn{8}{|c|}{ A beiratkozottak vallása } \\
\hline & & \multirow{2}{*}{ 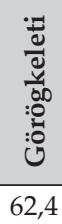 } & \multirow{2}{*}{ 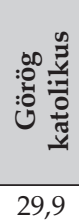 } & \multirow{2}{*}{ 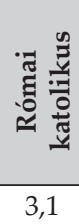 } & \multirow{2}{*}{ 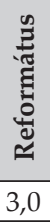 } & \multirow{2}{*}{ 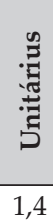 } & \multirow{2}{*}{ 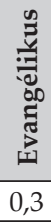 } & \multirow{2}{*}{ 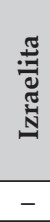 } & \multirow{2}{*}{ बि } \\
\hline \multirow{3}{*}{$1923 / 1924$} & Tanítóképzők & & & & & & & & \\
\hline & Tanítónőképzők & 75,7 & 21,6 & 1,6 & 0,3 & 0,1 & 0,2 & 0,5 & 0,1 \\
\hline & Összesen & 68,2 & 26,2 & 2,4 & 1,8 & 0,8 & 0,3 & 0,2 & 0,0 \\
\hline \multirow{3}{*}{$1924 / 1925$} & Tanítóképzők & 68,2 & 24,7 & 3,3 & 2,2 & 1,3 & 0,2 & 0,1 & 0,0 \\
\hline & Tanítónőképzők & 74,2 & 22,9 & 1,4 & 0,6 & - & 0,2 & 0,6 & 0,1 \\
\hline & Összesen & 70,5 & 24,0 & 2,5 & 1,6 & 0,8 & 0,2 & 0,3 & 0,1 \\
\hline \multirow{3}{*}{$1925 / 1926$} & Tanítóképzők & 69,5 & 25,8 & 2,1 & 1,7 & 0,8 & 0,1 & - & - \\
\hline & Tanítónőképzők & 74,0 & 23,2 & 1,4 & 0,6 & - & 0,1 & 0,6 & 0,2 \\
\hline & Összesen & 71,1 & 24,8 & 1,9 & 1,3 & 0,5 & 0,1 & 0,2 & 0,1 \\
\hline \multirow{3}{*}{$1926 / 1927$} & Tanítóképzők & 73,1 & 23,5 & 1,6 & 1,0 & 0,6 & 0,1 & 0,0 & - \\
\hline & Tanítónőképzők & 71,6 & 25,2 & 1,9 & 0,7 & - & 0,1 & 0,5 & 0,1 \\
\hline & Összesen & 72,6 & 24,1 & 1,7 & 0,9 & 0,4 & 0,1 & 0,2 & 0,0 \\
\hline \multirow{3}{*}{$1927 / 1928$} & Tanítóképzők & 67,4 & 29,6 & 1,5 & 0,9 & 0,4 & 0,1 & 0,0 & - \\
\hline & Tanítónőképzők & 66,1 & 29,6 & 2,0 & 1,2 & 0,2 & 0,2 & 0,5 & 0,2 \\
\hline & Összesen & 66,9 & 29,6 & 1,7 & 1,0 & 0,4 & 0,2 & 0,2 & 0,1 \\
\hline \multirow{3}{*}{ 1928/1929 } & Tanítóképzők & 66,4 & 31,1 & 1,3 & 0,8 & 0,3 & 0,0 & 0,0 & - \\
\hline & Tanítónőképzők & 65,2 & 29,7 & 2,7 & 1,6 & 0,2 & - & 0,4 & 0,1 \\
\hline & Összesen & 66,0 & 30,6 & 1,8 & 1,1 & 0,3 & 0,0 & 0,2 & 0,0 \\
\hline \multirow{3}{*}{ 1930/1931 } & Tanítóképzők & 58,3 & 37,5 & 3,2 & 1,0 & 0,4 & 0,3 & 0,0 & - \\
\hline & Tanítónőképzők & 61,4 & 32,0 & 4,3 & 1,5 & 0,2 & 0,1 & 0,3 & 0,0 \\
\hline & Összesen & 59,5 & 35,3 & 3,6 & 1,2 & 0,3 & 0,2 & 0,2 & 0,0 \\
\hline \multirow{3}{*}{$1931 / 1932$} & Tanítóképzők & 61,4 & 34,2 & 2,6 & 0,8 & 0,6 & 0,4 & 0,0 & - \\
\hline & Tanítónőképzők & 63,2 & 31,0 & 3,7 & 1,3 & 0,2 & 0,1 & 0,5 & - \\
\hline & Összesen & 62,1 & 33,0 & 3,0 & 1,0 & 0,4 & 0,3 & 0,2 & - \\
\hline \multirow{3}{*}{$1932 / 1933$} & Tanítóképzők & 62,5 & 31,8 & 3,1 & 1,3 & 0,5 & 0,6 & 0,1 & - \\
\hline & Tanítónőképzők & 61,0 & 31,2 & 4,2 & 2,5 & 0,3 & 0,2 & 0,6 & - \\
\hline & Összesen & 61,9 & 31,6 & 3,5 & 1,7 & 0,4 & 0,5 & 0,3 & - \\
\hline \multirow{3}{*}{$1935 / 1936$} & Tanítóképzők & 56,3 & 37,4 & 3,4 & 1,5 & 0,8 & 0,3 & 0,2 & 0,0 \\
\hline & Tanítónőképzők & 59,4 & 32,8 & 4,1 & 2,0 & 0,6 & 0,3 & 0,7 & 0,1 \\
\hline & Összesen & 57,5 & 35,6 & 3,7 & 1,7 & 0,7 & 0,3 & 0,4 & 0,0 \\
\hline \multirow{3}{*}{ 1936/1937 } & Tanítóképzők & 54,9 & 38,4 & 4,0 & 1,5 & 0,6 & 0,3 & 0,0 & 0,3 \\
\hline & Tanítónőképzők & 59,8 & 34,1 & 3,0 & 1,8 & 0,5 & 0,3 & 0,3 & 0,2 \\
\hline & Összesen & 56,8 & 36,7 & 3,6 & 1,6 & 0,5 & 0,3 & 0,1 & 0,2 \\
\hline
\end{tabular}


10. Az egyházi és egyesületi tanitóképzők diákjai és tanárai:

\begin{tabular}{|c|l|c|c|c|c|c|}
\hline $\begin{array}{c}\text { Egyházi és egyesületi } \\
\text { tanítóképzők }\end{array}$ & $\begin{array}{c}\text { Intézmények } \\
\text { száma }\end{array}$ & $\begin{array}{c}\text { Beiratkozott } \\
\text { diákok }\end{array}$ & \multicolumn{2}{|c|}{$\begin{array}{c}\text { Felsőbb osztályba } \\
\text { léptek }\end{array}$} & Tanerők \\
\hline \multirow{3}{*}{$\mathbf{1 9 2 6 / 1 9 2 7}$} & Fiú & 4 & 307 & 270 & 87,9 & 59 \\
\cline { 2 - 7 } & Lány & 9 & 601 & 541 & 90,0 & 91 \\
\cline { 2 - 7 } & Összesen & 13 & 908 & 811 & 89,3 & 150 \\
\hline \multirow{3}{*}{$\mathbf{1 9 2 7 / 1 9 2 8}$} & Fiú & 4 & 357 & 309 & 86,6 & 57 \\
\cline { 2 - 7 } & Lány & 8 & 597 & 539 & 90,3 & 71 \\
\cline { 2 - 7 } & Összesen & 12 & 954 & 848 & 88,9 & 128 \\
\hline \multirow{3}{*}{$\mathbf{1 9 2 8 / 1 9 2 9}$} & Fiú & 4 & 373 & 320 & 85,8 & 48 \\
\cline { 2 - 7 } & Lány & 8 & 741 & 660 & 89,1 & 80 \\
\cline { 2 - 7 } & Összesen & 12 & 1114 & 980 & 88,0 & 128 \\
\hline
\end{tabular}

11. Az állami gimnáziumok diákjai és tanárai:

\begin{tabular}{|c|c|c|c|c|c|}
\hline \multicolumn{2}{|c|}{ Állami gimnáziumok } & \multirow{2}{*}{$\begin{array}{c}\begin{array}{c}\text { Iskolák } \\
\text { száma }\end{array} \\
18 \\
\end{array}$} & \multirow{2}{*}{\begin{tabular}{|c|} 
Beiratkozottak \\
2054 \\
\end{tabular}} & \multirow{2}{*}{\begin{tabular}{|c|}
$\begin{array}{c}\text { Felsőbb } \\
\text { osztályba léptek }\end{array}$ \\
1684 \\
\end{tabular}} & \multirow{2}{*}{$\begin{array}{c}\begin{array}{c}\text { Tanárok } \\
\text { (mesterek nélkül) }\end{array} \\
100 \\
\end{array}$} \\
\hline $1923 / 1924$ & Fiú & & & & \\
\hline $1924 / 1925$ & Fiú & 23 & 2760 & 2150 & 126 \\
\hline $1925 / 1926$ & Fiú & 25 & 3190 & 2404 & 152 \\
\hline $1926 / 1927$ & Fiú & 26 & 3185 & 2483 & 166 \\
\hline \multirow{3}{*}{$1927 / 1928$} & Fiú & 27 & 3248 & 2483 & 179 \\
\hline & Vegyes & 2 & 180 & 148 & 11 \\
\hline & Összesen & 29 & 3428 & 2631 & 190 \\
\hline \multirow{3}{*}{$1928 / 1929$} & Fiú & 33 & 3423 & 2527 & 212 \\
\hline & Vegyes & 4 & 554 & 437 & 24 \\
\hline & Összesen & 37 & 3977 & 2964 & 236 \\
\hline \multirow{4}{*}{ 1930/1931 } & Fiú & 25 & 2452 & 1824 & 189 \\
\hline & Lány & 25 & 2149 & 1681 & 238 \\
\hline & Vegyes & 7 & 778 & 626 & 48 \\
\hline & Összesen & 57 & 5379 & 4131 & 475 \\
\hline \multirow{4}{*}{$1931 / 1932$} & Fiú & 19 & 2361 & 1920 & 171 \\
\hline & Lány & 23 & 2444 & 2085 & 256 \\
\hline & Vegyes & 10 & 1365 & 1156 & 84 \\
\hline & Összesen & 52 & 6170 & 5161 & 511 \\
\hline \multirow{4}{*}{$1932 / 1933$} & Fiú & 15 & 2289 & 1832 & 145 \\
\hline & Lány & 22 & 2648 & 2314 & 231 \\
\hline & Vegyes & 14 & 2067 & 1752 & 121 \\
\hline & Összesen & 51 & 7004 & 5898 & 497 \\
\hline \multirow{4}{*}{$1935 / 1936$} & Fiú & 11 & 1942 & 1556 & 120 \\
\hline & Lány & 19 & 2829 & 2449 & 208 \\
\hline & Vegyes & 19 & 2749 & 2347 & 44 \\
\hline & Összesen & 49 & 7520 & 6352 & 372 \\
\hline
\end{tabular}




\begin{tabular}{|l|l|l|l|l|l|}
\hline \multirow{4}{*}{$\mathbf{1 9 3 6 / 1 9 3 7}$} & Fiú & 10 & 1844 & 1520 & 106 \\
\cline { 2 - 6 } & Lány & 19 & 2907 & 2522 & 200 \\
\cline { 2 - 6 } & Vegyes & 19 & 2863 & 2498 & 180 \\
\cline { 2 - 6 } & Összesen & 48 & 7614 & 6540 & 486 \\
\hline
\end{tabular}

12. Az állami gimnáziumok diákjainak nemzetiségi megoszlása:

\begin{tabular}{|c|c|c|c|c|c|c|c|c|c|c|c|c|}
\hline \multicolumn{2}{|c|}{$\begin{array}{l}\text { Állami gimnáziu- } \\
\text { mok növendékei }\end{array}$} & \multicolumn{2}{|c|}{ 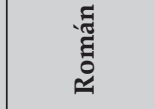 } & \multicolumn{2}{|c|}{$\begin{array}{l}\bar{\Xi} \\
\stackrel{\Xi}{0} \\
\check{Z}\end{array}$} & \multicolumn{2}{|c|}{ 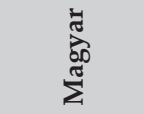 } & \multicolumn{2}{|c|}{ 惫 } & \multicolumn{2}{|c|}{$\begin{array}{l}\text { बैं } \\
\text { त्र }\end{array}$} & \multirow{2}{*}{ 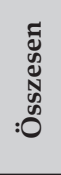 } \\
\hline & & & $\%$ & & $\%$ & & $\%$ & & $\%$ & & $\%$ & \\
\hline 1923/1924 & Fiú & 1439 & 70,1 & 253 & 12,3 & 249 & 12,1 & 82 & 4,0 & 31 & 1,5 & 2054 \\
\hline $1924 / 1925$ & Fiú & 1975 & 71,6 & 191 & 6,9 & 444 & 16,1 & 132 & 4,8 & 18 & 0,7 & 2760 \\
\hline $1925 / 1926$ & Fiú & 2396 & 75,1 & 163 & 5,1 & 493 & 15,5 & 131 & 4,1 & 7 & 0,2 & 3190 \\
\hline $1926 / 1927$ & Fiú & 2447 & 76,8 & 165 & 5,2 & 393 & 12,3 & 175 & 5,5 & 5 & 0,2 & 3185 \\
\hline \multirow{3}{*}{$1927 / 1928$} & Fiú & 2306 & 71,0 & 148 & 4,6 & 520 & 16,0 & 256 & 7,9 & 18 & 0,6 & 3248 \\
\hline & Vegyes & 171 & 95,0 & - & & 6 & 3,3 & 3 & 1,7 & - & & 180 \\
\hline & Összesen & 2477 & 72,3 & 148 & 4,3 & 526 & 15,3 & 259 & 7,6 & 18 & 0,5 & 3428 \\
\hline \multirow{3}{*}{ 1928/1929 } & Fiú & 2010 & 58,7 & 443 & 12,9 & 709 & 20,7 & 175 & 5,1 & 86 & 2,5 & 3423 \\
\hline & Vegyes & 440 & 79,4 & 11 & 2,0 & 48 & 8,7 & 38 & 6,9 & 17 & 3,1 & 554 \\
\hline & \begin{tabular}{|l|} 
Összesen \\
\end{tabular} & 2450 & 61,6 & 454 & 11,4 & 757 & 19,0 & 213 & 5,4 & 103 & 2,6 & 3977 \\
\hline \multirow{4}{*}{$1935 / 1936$} & Fiú & 970 & 49,9 & 394 & 20,3 & 431 & 22,2 & 109 & 5,6 & 38 & 2,0 & 1942 \\
\hline & \begin{tabular}{|l|} 
Lány \\
\end{tabular} & 1672 & 59,1 & 167 & 5,9 & 637 & 22,5 & 335 & 11,8 & 18 & 0,6 & 2829 \\
\hline & Vegyes & 1743 & 63,4 & 293 & 10,7 & 406 & 14,8 & 226 & 8,2 & 81 & 2,9 & 2749 \\
\hline & Összesen & 4385 & 58,3 & 854 & 11,4 & 1474 & 19,6 & 670 & 8,9 & 137 & 1,8 & 7520 \\
\hline \multirow{4}{*}{$1936 / 1937$} & Fiú & 1037 & 56,2 & 338 & 18,3 & 343 & 18,6 & 88 & 4,8 & 38 & 2,1 & 1844 \\
\hline & Lány & 1842 & 63,4 & 152 & 5,2 & 579 & 19,9 & 320 & 11,0 & 14 & 0,5 & 2907 \\
\hline & Vegyes & 1901 & 66,4 & 254 & 8,9 & 404 & 14,1 & 214 & 7,5 & 90 & 3,1 & 2863 \\
\hline & Összesen & 4780 & 62,8 & 744 & 9,8 & 1326 & 17,4 & 622 & 8,2 & 142 & 1,9 & 7614 \\
\hline
\end{tabular}

13. Az állami gimnáziumok növendékeinek felekezeti megoszlása:

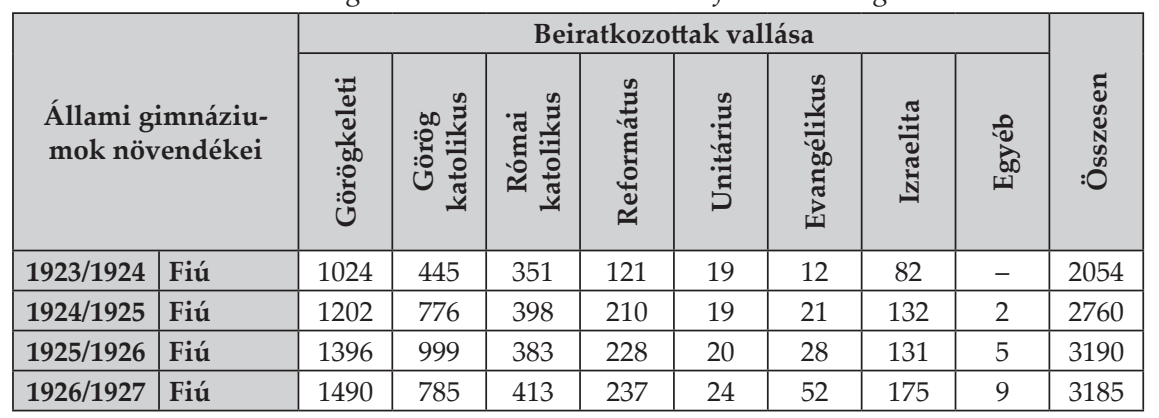




\begin{tabular}{|c|c|c|c|c|c|c|c|c|c|c|}
\hline \multirow{3}{*}{$1927 / 1928$} & Fiú & 1586 & 713 & 430 & 216 & 16 & 26 & 256 & 5 & 3248 \\
\hline & \begin{tabular}{|l|} 
Vegyes \\
\end{tabular} & 133 & 38 & 2 & 3 & - & 1 & 3 & - & 180 \\
\hline & Összesen & 1719 & 751 & 432 & 219 & 16 & 27 & 259 & 5 & 3428 \\
\hline \multirow{3}{*}{$1928 / 1929$} & Fiú & 1564 & 505 & 899 & 222 & 5 & 43 & 175 & 10 & 3423 \\
\hline & Vegyes & 367 & 84 & 47 & 7 & 2 & 9 & 38 & - & 554 \\
\hline & Összesen & 1931 & 589 & 946 & 229 & 7 & 52 & 213 & 10 & 3977 \\
\hline \multirow{4}{*}{$1930 / 1931$} & Fiú & 936 & 262 & 831 & 183 & 1 & 45 & 179 & 15 & 2452 \\
\hline & Lány & 620 & 447 & 476 & 225 & 12 & 56 & 300 & 13 & 2149 \\
\hline & \begin{tabular}{|l|} 
Vegyes \\
\end{tabular} & 401 & 148 & 94 & 40 & 6 & 15 & 74 & - & 778 \\
\hline & Összesen & 1957 & 857 & 1401 & 448 & 19 & 116 & 553 & 28 & 5379 \\
\hline \multirow{4}{*}{$1931 / 1932$} & Fiú & 865 & 244 & 744 & 163 & 99 & 53 & 185 & 8 & 2361 \\
\hline & Lány & 703 & 545 & 484 & 275 & 19 & 44 & 358 & 16 & 2444 \\
\hline & Vegyes & 677 & 247 & 205 & 61 & 8 & 17 & 147 & 3 & 1365 \\
\hline & Összesen & 2245 & 1036 & 1433 & 499 & 126 & 114 & 690 & 27 & 6170 \\
\hline \multirow{4}{*}{$1932 / 1933$} & Fiú & 801 & 272 & 738 & 151 & 47 & 48 & 224 & 8 & 2289 \\
\hline & Lány & 810 & 595 & 476 & 269 & 24 & 60 & 397 & 17 & 2648 \\
\hline & Vegyes & 887 & 366 & 376 & 174 & 10 & 30 & 221 & 3 & 2067 \\
\hline & Összesen & 2498 & 1233 & 1590 & 594 & 81 & 138 & 842 & 28 & 7004 \\
\hline \multirow{4}{*}{$1935 / 1936$} & Fiú & 878 & 95 & 641 & 148 & 7 & 54 & 109 & 10 & 1942 \\
\hline & Lány & 883 & 764 & 455 & 293 & 28 & 62 & 335 & 9 & 2829 \\
\hline & \begin{tabular}{|l|} 
Vegyes \\
\end{tabular} & 1344 & 413 & 554 & 158 & 17 & 33 & 226 & 4 & 2749 \\
\hline & Összesen & 3105 & 1272 & 1650 & 599 & 52 & 149 & 670 & 23 & 7520 \\
\hline \multirow{4}{*}{$1936 / 1937$} & Fiú & 950 & 81 & 537 & 127 & 5 & 46 & 88 & 10 & 1844 \\
\hline & Lány & 986 & 828 & 421 & 259 & 24 & 57 & 320 & 12 & 2907 \\
\hline & \begin{tabular}{|l|} 
Vegyes \\
\end{tabular} & 1481 & 439 & 521 & 162 & 11 & 30 & 214 & 5 & 2863 \\
\hline & Összesen & 3417 & 1348 & 1479 & 548 & 40 & 133 & 622 & 27 & 7614 \\
\hline
\end{tabular}

14. Az állami gimnáziumok növendékeinek felekezeti megoszlása, százalékban kifejezve:

\begin{tabular}{|c|c|c|c|c|c|c|c|c|c|}
\hline \multirow{2}{*}{\multicolumn{2}{|c|}{\begin{tabular}{|l|} 
Állami gimnáziu- \\
mok növendékei
\end{tabular}}} & \multicolumn{8}{|c|}{ Beiratkozottak vallása } \\
\hline & & \multirow{2}{*}{ 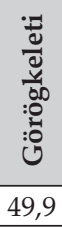 } & \multirow{2}{*}{ 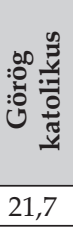 } & \multirow{2}{*}{ 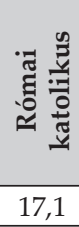 } & \multirow{2}{*}{ 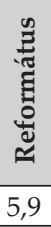 } & \multirow{2}{*}{ 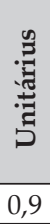 } & \multirow{2}{*}{ 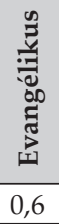 } & \multirow{2}{*}{ 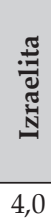 } & \multirow{2}{*}{$\begin{array}{l}\text { हि } \\
\overbrace{10} \\
-\end{array}$} \\
\hline 1923/1924 & Fiú & & & & & & & & \\
\hline 1924/1925 & Fiú & 43,6 & 28,1 & 14,4 & 7,6 & 0,7 & 0,8 & 4,8 & 0,1 \\
\hline $1925 / 1926$ & Fiú & 43,8 & 31,3 & 12,0 & 7,1 & 0,6 & 0,9 & 4,1 & 0,2 \\
\hline $1926 / 1927$ & Fiú & 46,8 & 24,6 & 13,0 & 7,4 & 0,8 & 1,6 & 5,5 & 0,3 \\
\hline \multirow{3}{*}{$1927 / 1928$} & Fiú & 48,8 & 22,0 & 13,2 & 6,7 & 0,5 & 0,8 & 7,9 & 0,2 \\
\hline & Vegyes & 73,9 & 21,1 & 1,1 & 1,7 & - & 0,6 & 1,7 & - \\
\hline & Összesen & 50,1 & 21,9 & 12,6 & 6,4 & 0,5 & 0,8 & 7,6 & 0,1 \\
\hline
\end{tabular}




\begin{tabular}{|c|c|c|c|c|c|c|c|c|c|}
\hline \multirow{3}{*}{$1928 / 1929$} & Fiú & 45,7 & 14,8 & 26,3 & 6,5 & 0,1 & 1,3 & 5,1 & 0,3 \\
\hline & Vegyes & 66,2 & 15,2 & 8,5 & 1,3 & 0,4 & 1,6 & 6,9 & - \\
\hline & Összesen & 48,6 & 14,8 & 23,8 & 5,8 & 0,2 & 1,3 & 5,4 & 0,3 \\
\hline \multirow{4}{*}{$1930 / 1931$} & Fiú & 38,2 & 10,7 & 33,9 & 7,5 & 0,0 & 1,8 & 7,3 & 0,6 \\
\hline & Lány & 28,9 & 20,8 & 22,1 & 10,5 & 0,6 & 2,6 & 14,0 & 0,6 \\
\hline & Vegyes & 51,5 & 19,0 & 12,1 & 5,1 & 0,8 & 1,9 & 9,5 & - \\
\hline & \begin{tabular}{|l|} 
Összesen \\
\end{tabular} & 36,4 & 15,9 & 26,0 & 8,3 & 0,4 & 2,2 & 10,3 & 0,5 \\
\hline \multirow{4}{*}{$1931 / 1932$} & Fiú & 36,6 & 10,3 & 31,5 & 6,9 & 4,2 & 2,2 & 7,8 & 0,3 \\
\hline & Lány & 28,8 & 22,3 & 19,8 & 11,3 & 0,8 & 1,8 & 14,6 & 0,7 \\
\hline & Vegyes & 49,6 & 18,1 & 15,0 & 4,5 & 0,6 & 1,2 & 10,8 & 0,2 \\
\hline & Összesen & 36,4 & 16,8 & 23,2 & 8,1 & 2,0 & 1,8 & 11,2 & 0,4 \\
\hline \multirow{4}{*}{$1932 / 1933$} & Fiú & 35,0 & 11,9 & 32,2 & 6,6 & 2,1 & 2,1 & 9,8 & 0,3 \\
\hline & Lány & 30,6 & 22,5 & 18,0 & 10,2 & 0,9 & 2,3 & 15,0 & 0,6 \\
\hline & Vegyes & 42,9 & 17,7 & 18,2 & 8,4 & 0,5 & 1,5 & 10,7 & 0,1 \\
\hline & Összesen & 35,7 & 17,6 & 22,7 & 8,5 & 1,2 & 2,0 & 12,0 & 0,4 \\
\hline \multirow{4}{*}{$1935 / 1936$} & Fiú & 45,2 & 4,9 & 33,0 & 7,6 & 0,4 & 2,8 & 5,6 & 0,5 \\
\hline & Lány & 31,2 & 27,0 & 16,1 & 10,4 & 1,0 & 2,2 & 11,8 & 0,3 \\
\hline & Vegyes & 48,9 & 15,0 & 20,2 & 5,7 & 0,6 & 1,2 & 8,2 & 0,1 \\
\hline & Összesen & 41,3 & 16,9 & 21,9 & 8,0 & 0,7 & 2,0 & 8,9 & 0,3 \\
\hline \multirow{4}{*}{$1936 / 1937$} & Fiú & 51,5 & 4,4 & 29,1 & 6,9 & 0,3 & 2,5 & 4,8 & 0,5 \\
\hline & Lány & 33,9 & 28,5 & 14,5 & 8,9 & 0,8 & 2,0 & 11,0 & 0,4 \\
\hline & Vegyes & 51,7 & 15,3 & 18,2 & 5,7 & 0,4 & 1,0 & 7,5 & 0,2 \\
\hline & Összesen & 44,9 & 17,7 & 19,4 & 7,2 & 0,5 & 1,7 & 8,2 & 0,4 \\
\hline
\end{tabular}

15. Érettségit nyújtó állami fiúlíceumok és II. fokú leány-középiskolák 1921-1928 között:

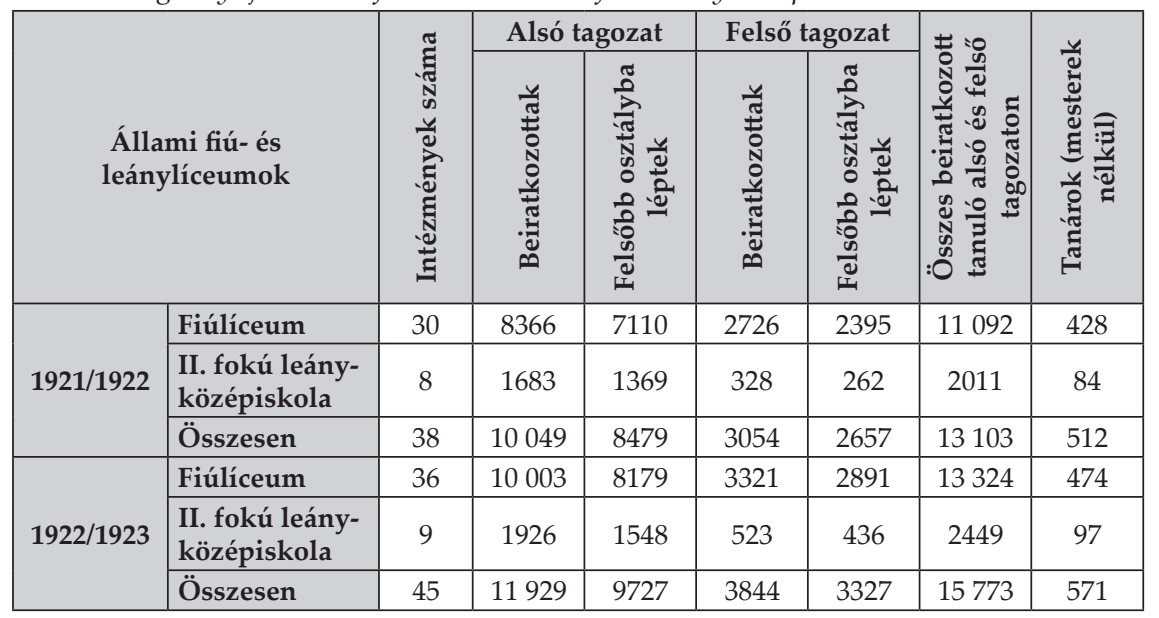




\begin{tabular}{|c|c|c|c|c|c|c|c|c|}
\hline \multirow{3}{*}{ 1923/1924 } & Fiúlíceum & 33 & 10709 & 8536 & 4127 & 3538 & 14836 & 488 \\
\hline & $\begin{array}{l}\text { II. fokú leány- } \\
\text { középiskola }\end{array}$ & 9 & 2466 & 1968 & 725 & 635 & 3191 & 123 \\
\hline & Összesen & 42 & 13175 & 10504 & 4852 & 4173 & 18027 & 611 \\
\hline \multirow{3}{*}{$1924 / 1925$} & Fiúlíceum & 35 & 11072 & 6169 & 4700 & 3170 & 15772 & 521 \\
\hline & $\begin{array}{l}\text { II. fokú leány- } \\
\text { középiskola }\end{array}$ & 10 & 2718 & 2086 & 905 & 723 & 3623 & 114 \\
\hline & Összesen & 45 & 13790 & 8255 & 5605 & 3893 & 19395 & 635 \\
\hline \multirow{3}{*}{$1925 / 1926$} & Fiúlíceum & 35 & 10457 & 7747 & 4753 & 3959 & 15210 & 502 \\
\hline & $\begin{array}{l}\text { II. fokú leány- } \\
\text { középiskola }\end{array}$ & 12 & 3003 & 2362 & 944 & 814 & 3947 & 143 \\
\hline & Összesen & 47 & 13460 & 10109 & 5697 & 4773 & 19157 & 645 \\
\hline \multirow{3}{*}{$1926 / 1927$} & Fiúlíceum & 37 & 9992 & 7488 & 4843 & 4144 & 14835 & 563 \\
\hline & $\begin{array}{l}\text { II. fokú leány- } \\
\text { középiskola }\end{array}$ & 14 & 3081 & 2405 & 969 & 845 & 4050 & 182 \\
\hline & Összesen & 51 & 13073 & 9893 & 5812 & 4989 & 18885 & 745 \\
\hline \multirow{3}{*}{$1927 / 1928$} & Fiúlíceum & 37 & 8987 & 6805 & 4980 & 4279 & 13967 & 574 \\
\hline & $\begin{array}{l}\text { II. fokú leány- } \\
\text { középiskola }\end{array}$ & 15 & 3055 & 2468 & 1136 & 992 & 4191 & 206 \\
\hline & Összesen & 52 & 12042 & 9273 & 6116 & 5271 & 18158 & 780 \\
\hline \multirow{3}{*}{$1928 / 1929$} & Fiúlíceum & 37 & 6076 & 4493 & 6588 & 4914 & 12664 & 546 \\
\hline & $\begin{array}{l}\text { II. fokú leány- } \\
\text { középiskola }\end{array}$ & 18 & 2575 & 1988 & 2090 & 1663 & 4665 & 242 \\
\hline & Összesen & 55 & 8651 & 6481 & 8678 & 6577 & 17329 & 788 \\
\hline
\end{tabular}

16. Érettségit nyújtó állami fiúlíceumok és II. fokú leány középiskolák (leánylíceumok) 1930-1936 között:

\begin{tabular}{|c|c|c|c|c|}
\hline \multicolumn{2}{|c|}{ Állami fiú- és leánylíceumok } & \multirow{2}{*}{$\begin{array}{c}\begin{array}{c}\text { Intézmények } \\
\text { száma }\end{array} \\
37 \\
\end{array}$} & \multirow{2}{*}{$\begin{array}{c}\begin{array}{c}\text { Összes beiratkozott } \\
\text { tanuló alsó és felső } \\
\text { tagozaton }\end{array} \\
11454 \\
\end{array}$} & \multirow{2}{*}{$\begin{array}{c}\begin{array}{c}\text { Tanárok } \\
\text { (mesterekkel) }\end{array} \\
701 \\
\end{array}$} \\
\hline \multirow{3}{*}{$1930 / 1931$} & Fiúlíceum & & & \\
\hline & $\begin{array}{l}\text { I. és II. fokú leány- } \\
\text { középiskola }\end{array}$ & 14 & 4101 & 288 \\
\hline & Összesen & 51 & 15555 & 989 \\
\hline \multirow{3}{*}{$1931 / 1932$} & Fiúlíceum & 37 & 11649 & 726 \\
\hline & $\begin{array}{l}\text { I. és II. fokú leány- } \\
\text { középiskola }\end{array}$ & 15 & 4087 & 308 \\
\hline & Összesen & 52 & 15736 & 1034 \\
\hline \multirow{3}{*}{$1932 / 1933$} & Fiúlíceum & 36 & 11852 & 730 \\
\hline & $\begin{array}{l}\text { I. és II. fokú leány- } \\
\text { középiskola }\end{array}$ & 14 & 4284 & 301 \\
\hline & Összesen & 50 & 16136 & 1031 \\
\hline
\end{tabular}




\begin{tabular}{|l|l|c|c|c|}
\hline \multirow{3}{*}{ 1935/1936 } & Fiúlíceum & 38 & 14518 & 720 \\
\cline { 2 - 5 } & Leánylíceum & 17 & 6165 & 370 \\
\cline { 2 - 5 } & Összesen & 55 & 20683 & 1090 \\
\hline \multirow{3}{*}{ 1936/1937 } & Fiúlíceum & 38 & 14905 & 882 \\
\cline { 2 - 5 } & Leánylíceum & 17 & 6428 & 402 \\
\cline { 2 - 5 } & Összesen & 55 & 21333 & 1284 \\
\hline
\end{tabular}

17. Az érettségit nyújtó állami fiúlíceumok és II. fokú leány-középiskolák (leánylíceumok) diákjainak etnikai megoszlása:

\begin{tabular}{|c|c|c|c|c|c|c|c|c|c|c|c|c|}
\hline \multirow{3}{*}{\multicolumn{2}{|c|}{$\begin{array}{c}\text { Állami fiú- és leánylí- } \\
\text { ceumok }\end{array}$}} & \multicolumn{11}{|c|}{ Beiratkozott tanulók nemzetisége alsó és felső tagozaton összesen } \\
\hline & & \multicolumn{2}{|c|}{ Román } & \multicolumn{2}{|c|}{ Német } & \multicolumn{2}{|c|}{ Magyar } & \multicolumn{2}{|c|}{ Zsidó } & \multicolumn{2}{|c|}{ Egyéb } & \multirow{2}{*}{$\begin{array}{c}\text { Össze- } \\
\text { sen }\end{array}$} \\
\hline & & & $\%$ & & $\%$ & & $\%$ & & $\%$ & & $\%$ & \\
\hline \multirow{3}{*}{ 1921/1922 } & Fiúlíceum & 5401 & 48,7 & & & & & 581 & 5,2 & 5110 & 46,1 & 11092 \\
\hline & \begin{tabular}{|l|} 
II. fokú \\
leány-- \\
középiskola
\end{tabular} & 1873 & 93,1 & & & & & 102 & 5,1 & 36 & 1,8 & 2011 \\
\hline & Összesen & 7274 & 55,5 & & & & & 683 & 5,2 & 5146 & 39,3 & 13103 \\
\hline \multirow{3}{*}{$1922 / 1923$} & Fiúlíceum & 6172 & 46,3 & & & & & 764 & 5,7 & 6388 & 47,9 & 13324 \\
\hline & \begin{tabular}{|l|} 
II. fokú \\
leány-- \\
középiskola
\end{tabular} & 2124 & 86,7 & & & & & 167 & 6,8 & 158 & 6,5 & 2449 \\
\hline & Összesen & 8296 & 52,6 & & & & & 931 & 5,9 & 6546 & 41,5 & 15773 \\
\hline \multirow{3}{*}{ 1923/1924 } & Fiúlíceum & 10652 & 71,8 & 950 & 6,4 & 1811 & 12,2 & 1112 & 7,5 & 311 & 2,1 & 14836 \\
\hline & \begin{tabular}{|l|} 
II. fokú \\
leány-- \\
középiskola
\end{tabular} & 2384 & 74,7 & 24 & 0,8 & 324 & 10,2 & 418 & 13,1 & 41 & 1,3 & 3191 \\
\hline & Összesen & 13036 & 72,3 & 974 & 5,4 & 2135 & 11,8 & 1530 & 8,5 & 352 & 2,0 & 18027 \\
\hline \multirow{3}{*}{$1924 / 1925$} & Fiúlíceum & 11203 & 71,0 & 1077 & 6,8 & 2109 & 13,4 & 1095 & 6,9 & 288 & 1,8 & 15772 \\
\hline & \begin{tabular}{|l|} 
II. fokú \\
leány-- \\
középiskola \\
\end{tabular} & 2707 & 74,7 & 48 & 1,3 & 299 & 8,3 & 510 & 14,1 & 59 & 1,6 & 3623 \\
\hline & \begin{tabular}{|l|l} 
Összesen \\
\end{tabular} & 13910 & 71,7 & 1125 & 5,8 & 2408 & 12,4 & 1605 & 8,3 & 347 & 1,8 & 19395 \\
\hline \multirow{3}{*}{$1925 / 1926$} & Fiúlíceum & 11077 & 72,8 & 1118 & 7,4 & 1807 & 11,9 & 975 & 6,4 & 233 & 1,5 & 15210 \\
\hline & \begin{tabular}{|l|} 
II. fokú \\
leány- \\
középiskola
\end{tabular} & 3016 & 76,4 & 59 & 1,5 & 325 & 8,2 & 499 & 12,6 & 48 & 1,2 & 3947 \\
\hline & Összesen & 14093 & 73,6 & 1177 & 6,1 & 2132 & 11,1 & 1474 & 7,7 & 281 & 1,5 & 19157 \\
\hline \multirow{3}{*}{$1926 / 1927$} & Fiúlíceum & 11103 & 74,8 & 972 & 6,6 & 1559 & 10,5 & 935 & 6,3 & 266 & 1,8 & 14835 \\
\hline & $\begin{array}{l}\text { II. fokú } \\
\text { leány- } \\
\text { középiskola }\end{array}$ & 3181 & 78,5 & 57 & 1,4 & 248 & 6,1 & 513 & 12,7 & 51 & 1,3 & 4050 \\
\hline & Összesen & 14284 & 75,6 & 1029 & 5,4 & 1807 & 9,6 & 1448 & 7,7 & 317 & 1,7 & 18885 \\
\hline
\end{tabular}




\begin{tabular}{|c|c|c|c|c|c|c|c|c|c|c|c|c|}
\hline \multirow{3}{*}{$1927 / 1928$} & Fiúlíceum & 10344 & 74,1 & 877 & 6,3 & 1502 & 10,8 & 1002 & 7,2 & 242 & 1,7 & 13967 \\
\hline & $\begin{array}{l}\text { II. fokú } \\
\text { leány- } \\
\text { középiskola }\end{array}$ & 3183 & 75,9 & 59 & 1,4 & 317 & 7,6 & 570 & 13,6 & 62 & 1,5 & 4191 \\
\hline & Összesen & 13527 & 74,5 & 936 & 5,2 & 1819 & 10,0 & 1572 & 8,7 & 304 & 1,7 & 18158 \\
\hline \multirow{3}{*}{ 1928/1929 } & Fiúlíceum & 9451 & 74,6 & 751 & 5,9 & 1341 & 10,6 & 944 & 7,5 & 177 & 1,4 & 12664 \\
\hline & $\begin{array}{l}\text { II. fokú } \\
\text { leány- } \\
\text { középiskola }\end{array}$ & 3495 & 74,9 & 111 & 2,4 & 392 & 8,4 & 620 & 13,3 & 47 & 1,0 & 4665 \\
\hline & Összesen & 12946 & 74,7 & 862 & 5,0 & 1733 & 10,0 & 1564 & 9,0 & 224 & 1,3 & 17329 \\
\hline \multirow{3}{*}{$1935 / 1936$} & Fiúlíceum & 10235 & 70,5 & 1021 & 7,0 & 1629 & 11,2 & 1418 & 9,8 & 215 & 1,5 & 14518 \\
\hline & $\begin{array}{l}\text { Leánylíce- } \\
\text { um }\end{array}$ & 4249 & 68,9 & 163 & 2,6 & 530 & 8,6 & 1168 & 18,9 & 55 & 0,9 & 6165 \\
\hline & Összesen & 14484 & 70,0 & 1184 & 5,7 & 2159 & 10,4 & 2586 & 12,5 & 270 & 1,3 & 20683 \\
\hline \multirow{3}{*}{ 1936/1937 } & Fiúlíceum & 10769 & 72,3 & 985 & 6,6 & 1538 & 10,3 & 1367 & 9,2 & 246 & 1,7 & 14905 \\
\hline & $\begin{array}{l}\text { Leánylíce- } \\
\text { um }\end{array}$ & 4600 & 71,6 & 117 & 1,8 & 527 & 8,2 & 1135 & 17,7 & 49 & 0,8 & 6428 \\
\hline & Összesen & 15369 & 72,0 & 1102 & 5,2 & 2065 & 9,7 & 2502 & 11,7 & 295 & 1,4 & 21333 \\
\hline
\end{tabular}

18. Az érettségit nyújtó állami fiúlíceumok és II. fokú leány-középiskolák (leánylíceumok) diákjainak felekezeti megoszlása:

\begin{tabular}{|c|c|c|c|c|c|c|c|c|c|c|}
\hline \multirow{2}{*}{\multicolumn{2}{|c|}{$\begin{array}{c}\text { Állami fiú- és leánylíce- } \\
\text { umok }\end{array}$}} & \multicolumn{9}{|c|}{$\begin{array}{c}\text { Beiratkozott tanulók felekezeti megoszlása alsó és felső } \\
\text { tagozaton összesen }\end{array}$} \\
\hline & & \multirow{2}{*}{ 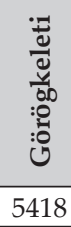 } & \multirow{2}{*}{ 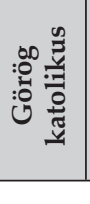 } & 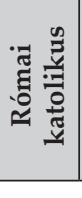 & 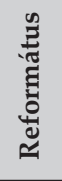 & 菢 & 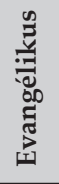 & \multirow{2}{*}{ 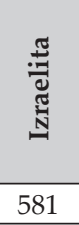 } & \multirow{2}{*}{ 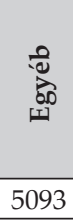 } & \multirow{2}{*}{ 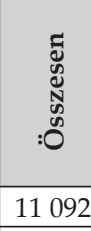 } \\
\hline \multirow{3}{*}{$1921 / 1922$} & Fiúlíceum & & & & & & & & & \\
\hline & $\begin{array}{l}\text { II. fokú leány- } \\
\text { középiskola }\end{array}$ & 1400 & & & & & & 102 & 21 & 2011 \\
\hline & Összesen & 6818 & & & & & & 683 & 5114 & 13103 \\
\hline \multirow{3}{*}{$1922 / 1923$} & Fiúlíceum & 6212 & & & & & & 764 & 6348 & 13324 \\
\hline & $\begin{array}{l}\text { II. fokú leány- } \\
\text { középiskola }\end{array}$ & 1637 & & & & & & 167 & 177 & 2449 \\
\hline & Összesen & 7849 & & & & & & 931 & 6525 & 15773 \\
\hline \multirow{3}{*}{$1923 / 1924$} & Fiúlíceum & 6454 & 4301 & 2039 & 671 & 29 & 136 & 1112 & 94 & 14836 \\
\hline & $\begin{array}{l}\text { II. fokú leány- } \\
\text { középiskola }\end{array}$ & 1889 & 509 & 165 & 169 & 11 & 23 & 418 & 7 & 3191 \\
\hline & Összesen & 8343 & 4810 & 2204 & 840 & 40 & 159 & 1530 & 101 & 18027 \\
\hline \multirow{3}{*}{$1924 / 1925$} & Fiúlíceum & 6938 & 4407 & 2221 & 718 & 74 & 255 & 1095 & 64 & 15772 \\
\hline & \begin{tabular}{|l|}
$\begin{array}{l}\text { II. fokú leány- } \\
\text { középiskola }\end{array}$ \\
\end{tabular} & 2093 & 614 & 183 & 152 & 13 & 40 & 510 & 18 & 3623 \\
\hline & Összesen & 9031 & 5021 & 2404 & 870 & 87 & 295 & 1605 & 82 & 19395 \\
\hline
\end{tabular}




\begin{tabular}{|c|c|c|c|c|c|c|c|c|c|c|}
\hline \multirow{3}{*}{$1925 / 1926$} & Fiúlíceum & 6949 & 4210 & 2146 & 626 & 51 & 223 & 975 & 30 & 15210 \\
\hline & $\begin{array}{l}\text { II. fokú leány- } \\
\text { középiskola }\end{array}$ & 2204 & 818 & 208 & 151 & 27 & 38 & 499 & 2 & 3947 \\
\hline & Összesen & 9153 & 5028 & 2354 & 777 & 78 & 261 & 1474 & 32 & 19157 \\
\hline \multirow{3}{*}{$1926 / 1927$} & Fiúlíceum & 7075 & 4091 & 1801 & 643 & 31 & 165 & 935 & 94 & 14835 \\
\hline & \begin{tabular}{|l|} 
II. fokú leány- \\
középiskola
\end{tabular} & 2202 & 979 & 186 & 116 & 20 & 32 & 513 & 2 & 4050 \\
\hline & Összesen & 9277 & 5070 & 1987 & 759 & 51 & 197 & 1448 & 96 & 18885 \\
\hline \multirow{3}{*}{$1927 / 1928$} & Fiúlíceum & 6690 & 3791 & 1674 & 555 & 37 & 169 & 1002 & 49 & 13967 \\
\hline & \begin{tabular}{|l|} 
II. fokú leá \\
középiskol
\end{tabular} & 2276 & 936 & 215 & 142 & 10 & 42 & 570 & & 4191 \\
\hline & Összesen & 8966 & 4727 & 1889 & 697 & 47 & 211 & 1572 & 49 & 18158 \\
\hline \multirow{3}{*}{$1928 / 1929$} & Fiúlí & 6131 & 3368 & 1457 & 545 & 39 & 138 & 944 & 42 & 12664 \\
\hline & \begin{tabular}{|l|}
$\begin{array}{l}\text { II. fokú leá } \\
\text { középiskol }\end{array}$ \\
\end{tabular} & 2405 & 1080 & 288 & 173 & 14 & 84 & 620 & 1 & 4665 \\
\hline & Összesen & 536 & 4448 & 1745 & 718 & 53 & 222 & 1564 & 43 & 17329 \\
\hline \multirow{3}{*}{$1930 / 1931$} & Fiúlíc & 5292 & 3215 & 1356 & 447 & 40 & 136 & 946 & 22 & 11454 \\
\hline & $\begin{array}{l}\text { I. és II. fokú } \\
\text { leány-közép- } \\
\text { iskola }\end{array}$ & 1931 & 1004 & 271 & 142 & 15 & 49 & 687 & 2 & 4101 \\
\hline & Összesen & 223 & 4219 & 1627 & 589 & 55 & 185 & 1633 & 24 & 5555 \\
\hline \multirow{3}{*}{$1931 / 1932$} & Fiúlíc & 5145 & 3244 & 1544 & 489 & 40 & 138 & 1008 & 41 & 11649 \\
\hline & $\begin{array}{l}\text { I. és II. fokú } \\
\text { leány-közép- } \\
\text { iskola }\end{array}$ & 1854 & 992 & 254 & 139 & 14 & 58 & 763 & 13 & 4087 \\
\hline & \begin{tabular}{|l|} 
Összesen \\
\end{tabular} & 6999 & 4236 & 1798 & 628 & 54 & 196 & 1771 & 54 & 15736 \\
\hline \multirow{3}{*}{$1932 / 1933$} & \begin{tabular}{|l|} 
Fiúlíceum \\
\end{tabular} & 5098 & 3172 & 1714 & 517 & 42 & 161 & 1109 & 39 & 11852 \\
\hline & $\begin{array}{l}\text { I. és II. fokú } \\
\text { leány-közép- } \\
\text { iskola } \\
\end{array}$ & 1906 & 1043 & 255 & 153 & 17 & 68 & 834 & 8 & 4284 \\
\hline & Összesen & 7004 & 4215 & 1969 & 670 & 59 & 229 & 1943 & 47 & 16136 \\
\hline \multirow{3}{*}{$1935 / 1936$} & \begin{tabular}{|l|} 
Fiúlíceum \\
\end{tabular} & 6421 & 3892 & 1886 & 560 & 54 & 251 & 1418 & 36 & 14518 \\
\hline & Leánylíceum & 2726 & 1518 & 356 & 228 & 58 & 103 & 1168 & 8 & 6165 \\
\hline & Összesen & 9147 & 5410 & 2242 & 788 & 112 & 354 & 2586 & 44 & 20683 \\
\hline \multirow{3}{*}{$1936 / 1937$} & Fiúlíceum & 6692 & 4163 & 1867 & 524 & 40 & 215 & 1367 & 37 & 14905 \\
\hline & Leánylíceu & 3025 & 1573 & 332 & 226 & 57 & 77 & 1135 & 3 & 6428 \\
\hline & Összesen & 9717 & 5736 & 2199 & 750 & 97 & 292 & 2502 & 40 & 21333 \\
\hline
\end{tabular}


19. Az érettségit nyújtó állami fiúlíceumok és II. fokú leány-középiskolák (leánylíceumok) diákjainak felekezeti megoszlása, százalékban kifejezve:

\begin{tabular}{|c|c|c|c|c|c|c|c|c|c|}
\hline \multirow{2}{*}{\multicolumn{2}{|c|}{$\begin{array}{l}\text { Állami fiú- és leánylíce- } \\
\text { umok }\end{array}$}} & \multicolumn{8}{|c|}{$\begin{array}{c}\text { Beiratkozott tanulók felekezeti megoszlása alsó és felső } \\
\text { tagozaton összesen }\end{array}$} \\
\hline & & \multirow{2}{*}{ 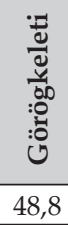 } & 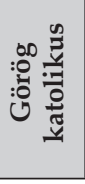 & 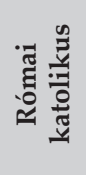 & 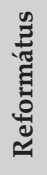 & & 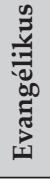 & \multirow{2}{*}{ 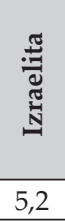 } & \multirow{2}{*}{$\begin{array}{l}\text { बे } \\
\text { को } \\
11 \\
45,\end{array}$} \\
\hline \multirow{3}{*}{ 1921/1922 } & Fiúlíceum & & & & & & & & \\
\hline & \begin{tabular}{|l|} 
II. fokú leány- \\
középiskola
\end{tabular} & 69,6 & & & & & & 5,1 & 1,0 \\
\hline & Összesen & 52,0 & & & & & & 5,2 & 39,0 \\
\hline \multirow{3}{*}{$1922 / 1923$} & Fiúlíceum & 46,6 & & & & & & 5,7 & 47,6 \\
\hline & \begin{tabular}{|l} 
II. fokú leány- \\
középiskola
\end{tabular} & 66,8 & & & & & & 6,8 & 7,2 \\
\hline & Összesen & 49,8 & & & & & & 5,9 & 41,4 \\
\hline \multirow{3}{*}{$1923 / 1924$} & Fiúlíceum & 43,5 & 29,0 & 13,7 & 4,5 & 0,2 & 0,9 & 7,5 & 0,6 \\
\hline & \begin{tabular}{|l|} 
II. fokú leány- \\
középiskola
\end{tabular} & 59,2 & 16,0 & 5,2 & 5,3 & 0,3 & 0,7 & 13,1 & 0,2 \\
\hline & \begin{tabular}{|l|l|} 
Összesen \\
\end{tabular} & 46,3 & 26,7 & 12,2 & 4,7 & 0,2 & 0,9 & 8,5 & 0,6 \\
\hline \multirow{3}{*}{$1924 / 1925$} & Fiúlíceum & 44,0 & 27,9 & 14,1 & 4,6 & 0,5 & 1,6 & 6,9 & 0,4 \\
\hline & \begin{tabular}{|l|} 
II. fokú leány- \\
középiskola
\end{tabular} & 57,8 & 16,9 & 5,1 & 4,2 & 0,4 & 1,1 & 14,1 & 0,5 \\
\hline & 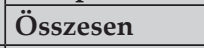 & 46,6 & 25,9 & 12,4 & 4,5 & 0,4 & 1,5 & 8,3 & 0,4 \\
\hline \multirow{3}{*}{$1925 / 1926$} & Fiúlíceum & 45,7 & 27,7 & 14,1 & 4,1 & 0,3 & 1,5 & 6,4 & 0,2 \\
\hline & \begin{tabular}{|l|} 
II. fokú leány- \\
középiskola
\end{tabular} & 55,8 & 20,7 & 5,3 & 3,8 & 0,7 & 1,0 & 12,6 & 0,1 \\
\hline & Összesen & 47,8 & 26,2 & 12,3 & 4,1 & 0,4 & 1,4 & 7,7 & 0,2 \\
\hline \multirow{3}{*}{$1926 / 1927$} & Fiúlíceum & 47,7 & 27,6 & 12,1 & 4,3 & 0,2 & 1,1 & 6,3 & 0,6 \\
\hline & \begin{tabular}{|l|}
$\begin{array}{l}\text { II. fokú leány- } \\
\text { középiskola }\end{array}$ \\
\end{tabular} & 54,4 & 24,2 & 4,6 & 2,9 & 0,5 & 0,8 & 12,7 & 0,0 \\
\hline & Összesen & 49,1 & 26,8 & 10,5 & 4,0 & 0,3 & 1,0 & 7,7 & 0,5 \\
\hline \multirow{3}{*}{$1927 / 1928$} & Fiúlíceum & 47,9 & 27,1 & 12,0 & 4,0 & 0,3 & 1,2 & 7,2 & 0,4 \\
\hline & \begin{tabular}{|l|} 
II. fokú leány- \\
középiskola
\end{tabular} & 54,3 & 22,3 & 5,1 & 3,4 & 0,2 & 1,0 & 13,6 & 0,0 \\
\hline & 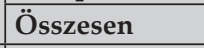 & 49,4 & 26,0 & 10,4 & 3,8 & 0,3 & 1,2 & 8,7 & 0,3 \\
\hline \multirow{3}{*}{$1928 / 1929$} & Fiúlíceum & 48,4 & 26,6 & 11,5 & 4,3 & 0,3 & 1,1 & 7,5 & 0,3 \\
\hline & $\begin{array}{l}\text { II. fokú leány- } \\
\text { középiskola }\end{array}$ & 51,6 & 23,2 & 6,2 & 3,7 & 0,3 & 1,8 & 13,3 & 0,0 \\
\hline & Összesen & 49,3 & 25,7 & 10,1 & 4,1 & 0,3 & 1,3 & 9,0 & 0,2 \\
\hline
\end{tabular}




\begin{tabular}{|c|c|c|c|c|c|c|c|c|c|}
\hline \multirow{3}{*}{$1930 / 1931$} & Fiúlíceum & 46,2 & 28,1 & 11,8 & 3,9 & 0,3 & 1,2 & 8,3 & 0,2 \\
\hline & $\begin{array}{l}\text { I. és II. fokú } \\
\text { leány-közép- } \\
\text { iskola }\end{array}$ & 47,1 & 24,5 & 6,6 & 3,5 & 0,4 & 1,2 & 16,8 & 0,0 \\
\hline & Összesen & 46,4 & 27,1 & 10,5 & 3,8 & 0,4 & 1,2 & 10,5 & 0,2 \\
\hline \multirow{3}{*}{ 1931/1932 } & Fiúlíceum & 44,2 & 27,8 & 13,3 & 4,2 & 0,3 & 1,2 & 8,7 & 0,4 \\
\hline & $\begin{array}{l}\text { I. és II. fokú } \\
\text { leány-közép- } \\
\text { iskola }\end{array}$ & 45,4 & 24,3 & 6,2 & 3,4 & 0,3 & 1,4 & 18,7 & 0,3 \\
\hline & Összesen & 44,5 & 26,9 & 11,4 & 4,0 & 0,3 & 1,2 & 11,3 & 0,3 \\
\hline \multirow{3}{*}{$1932 / 1933$} & Fiúlíceum & 43,0 & 26,8 & 14,5 & 4,4 & 0,4 & 1,4 & 9,4 & 0,3 \\
\hline & $\begin{array}{l}\text { I. és II. fokú } \\
\text { leány-közép- } \\
\text { iskola }\end{array}$ & 44,5 & 24,3 & 6,0 & 3,6 & 0,4 & 1,6 & 19,5 & 0,2 \\
\hline & Összesen & 43,4 & 26,1 & 12,2 & 4,2 & 0,4 & 1,4 & 12,0 & 0,3 \\
\hline \multirow{3}{*}{$1935 / 1936$} & Fiúlíceum & 44,2 & 26,8 & 13,0 & 3,9 & 0,4 & 1,7 & 9,8 & 0,2 \\
\hline & Leánylíceum & 44,2 & 24,6 & 5,8 & 3,7 & 0,9 & 1,7 & 18,9 & 0,1 \\
\hline & Összesen & 44,2 & 26,2 & 10,8 & 3,8 & 0,5 & 1,7 & 12,5 & 0,2 \\
\hline \multirow{3}{*}{ 1936/1937 } & Fiúlíceum & 44,9 & 27,9 & 12,5 & 3,5 & 0,3 & 1,4 & 9,2 & 0,2 \\
\hline & Leánylíceum & 47,1 & 24,5 & 5,2 & 3,5 & 0,9 & 1,2 & 17,7 & 0,0 \\
\hline & Összesen & 45,5 & 26,9 & 10,3 & 3,5 & 0,5 & 1,4 & 11,7 & 0,2 \\
\hline
\end{tabular}

20. Az állami felsókereskedelmi iskolák diákjai és tanárai:

\begin{tabular}{|c|l|c|c|c|c|}
\hline \multicolumn{2}{|c|}{$\begin{array}{c}\text { Állami felsőkereske- } \\
\text { delmi iskolák }\end{array}$} & $\begin{array}{c}\text { Intézmények } \\
\text { száma }\end{array}$ & Beiratkozottak & $\begin{array}{c}\text { Felsőbb } \\
\text { osztályba } \\
\text { léptek }\end{array}$ & $\begin{array}{c}\text { Tanárok } \\
\text { (mesterek } \\
\text { nélkül) }\end{array}$ \\
\hline \multirow{3}{*}{ 1921/1922 } & Fiú & 10 & 1134 & 947 & 99 \\
\cline { 2 - 6 } & Lány & 3 & 175 & 153 & 24 \\
\cline { 2 - 6 } & Összesen & 13 & 1309 & 1100 & 123 \\
\hline \multirow{3}{*}{$\mathbf{1 9 2 2 / 1 9 2 3}$} & Fiú & 10 & 1003 & 845 & 60 \\
\cline { 2 - 6 } & Lány & 4 & 178 & 149 & 31 \\
\cline { 2 - 6 } & Összesen & 14 & 1181 & 994 & 91 \\
\hline \multirow{3}{*}{$\mathbf{1 9 2 3 / 1 9 2 4}$} & Fiú & 10 & 1135 & 869 & 91 \\
\cline { 2 - 6 } & Lány & 5 & 321 & 270 & 36 \\
\cline { 2 - 6 } & Összesen & 15 & 1456 & 1139 & 127 \\
\hline \multirow{3}{*}{$\mathbf{1 9 2 4 / 1 9 2 5}$} & Fiú & 12 & 1583 & 1279 & 96 \\
\cline { 2 - 6 } & Lány & 6 & 494 & 282 & 38 \\
\cline { 2 - 6 } & Összesen & 18 & 2077 & 1561 & 134 \\
\hline & Fiú & 12 & 2051 & 1603 & 109 \\
\cline { 2 - 6 } & Lány & 6 & 562 & 482 & 43 \\
\cline { 2 - 6 } & Összesen & 18 & 2613 & 2085 & 152 \\
\hline
\end{tabular}




\begin{tabular}{|c|c|c|c|c|c|}
\hline \multirow{3}{*}{$1926 / 1927$} & Fiú & 12 & 2297 & 1793 & 134 \\
\hline & Lány & 7 & 750 & 612 & 73 \\
\hline & Összesen & 19 & 3047 & 2405 & 207 \\
\hline \multirow{3}{*}{$1927 / 1928$} & Fiú & 15 & 2589 & 2017 & 169 \\
\hline & Lány & 7 & 804 & 644 & 70 \\
\hline & Összesen & 22 & 3393 & 2661 & 239 \\
\hline \multirow{3}{*}{$1928 / 1929$} & Fiú & 13 & 2538 & 2009 & 156 \\
\hline & Lány & 7 & 821 & 639 & 80 \\
\hline & Összesen & 20 & 3359 & 2648 & 236 \\
\hline \multirow{3}{*}{$1930 / 1931$} & Fiú & 20 & 3130 & 2431 & 223 \\
\hline & Lány & 7 & 771 & 643 & 82 \\
\hline & Összesen & 27 & 3901 & 3074 & 305 \\
\hline \multirow{3}{*}{$1931 / 1932$} & Fiú & 16 & 2529 & 2088 & 296 \\
\hline & Lány & 6 & 626 & 556 & 69 \\
\hline & Összesen & 22 & 3155 & 2644 & 365 \\
\hline \multirow{3}{*}{$1932 / 1933$} & Fiú & 15 & 1865 & 1614 & 176 \\
\hline & Lány & 6 & 463 & 399 & 76 \\
\hline & Összesen & 21 & 2328 & 2013 & 252 \\
\hline \multirow{3}{*}{$1935 / 1936$} & Fiú & 16 & 1422 & 1047 & 188 \\
\hline & Lány & 6 & 404 & 325 & 80 \\
\hline & Összesen & 22 & 1826 & 1372 & 268 \\
\hline \multirow{3}{*}{$\begin{array}{l}\text { 1936/1937 } \\
\text { líceum }\end{array}$} & Fiú & 16 & 2173 & 1696 & 246 \\
\hline & Lány & 6 & 778 & 613 & 106 \\
\hline & Összesen & 22 & 2951 & 2309 & 352 \\
\hline
\end{tabular}

21. Az állami felsókereskedelmi iskolákba beiratkozott diákok nemzetiségi megoszlása:

\begin{tabular}{|c|c|c|c|c|c|c|c|c|c|c|c|c|}
\hline \multirow{3}{*}{\multicolumn{2}{|c|}{$\begin{array}{l}\text { Állami felsőkereske- } \\
\text { delmi iskolák }\end{array}$}} & \multicolumn{11}{|c|}{ Beiratkozott diákok nemzetisége } \\
\hline & & \multicolumn{2}{|c|}{ Román } & \multicolumn{2}{|c|}{ Német } & \multicolumn{2}{|c|}{ Magyar } & \multicolumn{2}{|c|}{ Zsidó } & \multicolumn{2}{|c|}{ Egyéb } & \multirow{2}{*}{$\begin{array}{l}\text { Ösz- } \\
\text { szesen }\end{array}$} \\
\hline & & & $\%$ & & $\%$ & & $\%$ & & $\%$ & & $\%$ & \\
\hline \multirow{3}{*}{ 1921/1922 } & Fiú & 279 & 24,6 & & & & & 139 & 12,3 & 716 & 63,1 & 1134 \\
\hline & Lány & 68 & 38,9 & & & & & 46 & 26,3 & 61 & 34,9 & 175 \\
\hline & Össze & 347 & 26,5 & & & & & 185 & 14,1 & 777 & 59,4 & 1309 \\
\hline \multirow{3}{*}{$1922 / 1923$} & Fiú & 532 & 53,0 & & & & & 183 & 18,2 & 288 & 28,7 & 1003 \\
\hline & Lány & 89 & 50,0 & & & & & 37 & 20,8 & 52 & 29,2 & 178 \\
\hline & Összesen & 621 & 52,6 & & & & & 220 & 18,6 & 340 & 28,8 & 1181 \\
\hline \multirow{3}{*}{$1923 / 1924$} & Fiú & 671 & 59,1 & 74 & 6,5 & 193 & 17,0 & 180 & 15,9 & 17 & 1,5 & 1135 \\
\hline & Lány & 174 & 54,2 & 17 & 5,3 & 72 & 22,4 & 56 & 17,4 & 2 & 0,6 & 321 \\
\hline & Össze & 845 & 58,0 & 91 & 6,3 & 265 & 18,2 & 236 & 16,2 & 19 & 1,3 & 1456 \\
\hline \multirow{3}{*}{$1924 / 1925$} & Fiú & 1053 & 66,5 & 114 & 7,2 & 226 & 14,3 & 171 & 10,8 & 19 & 1,2 & 1583 \\
\hline & Lány & 320 & 64,8 & 32 & 6,5 & 73 & 14,8 & 59 & 11,9 & 10 & 2,0 & 494 \\
\hline & Összesen & 1373 & 66,1 & 146 & 7,0 & 299 & 14,4 & 230 & 11,1 & 29 & 1,4 & 2077 \\
\hline
\end{tabular}




\begin{tabular}{|c|c|c|c|c|c|c|c|c|c|c|c|c|}
\hline \multirow{3}{*}{$1925 / 1926$} & Fiú & 1499 & 73,1 & 126 & 6,1 & 247 & 12,0 & 159 & 7,8 & 20 & 1,0 & 2051 \\
\hline & Lány & 416 & 74,0 & 31 & 5,5 & 71 & 12,6 & 38 & 6,8 & 6 & 1,1 & 562 \\
\hline & Összesen & 1915 & 73,3 & 157 & 6,0 & 318 & 12,2 & 197 & 7,5 & 26 & 1,0 & 2613 \\
\hline \multirow{3}{*}{$1926 / 1927$} & Fiú & 1718 & 74,8 & 153 & 6,7 & 270 & 11,8 & 128 & 5,6 & 28 & 1,2 & 2297 \\
\hline & Lány & 583 & 77,7 & 18 & 2,4 & 73 & 9,7 & 37 & 4,9 & 39 & 5,2 & 750 \\
\hline & Össze & 2301 & 75,5 & 171 & 5,6 & 343 & 11,3 & 165 & 5,4 & 67 & 2,2 & 3047 \\
\hline \multirow{3}{*}{$1927 / 1928$} & Fiú & 1932 & 74,6 & 189 & 7,3 & 298 & 11,5 & 138 & 5,3 & 32 & 1,2 & 2589 \\
\hline & Lány & 627 & 78,0 & 23 & 2,9 & 106 & 13,2 & 41 & 5,1 & 7 & 0,9 & 804 \\
\hline & Össze & 2559 & 75,4 & 212 & 6,2 & 404 & 11,9 & 179 & 5,3 & 39 & 1,1 & 3393 \\
\hline \multirow{3}{*}{$1928 / 1929$} & Fiú & 1888 & 74,4 & 195 & 7,7 & 294 & 11,6 & 134 & 5,3 & 27 & 1,1 & 2538 \\
\hline & Lány & 660 & 80,4 & 20 & 2,4 & 90 & 11,0 & 47 & 5,7 & 4 & 0,5 & 821 \\
\hline & Össze & 2548 & 75,9 & 215 & 6,4 & 384 & 11,4 & 181 & 5,4 & 31 & 0,9 & 3359 \\
\hline \multirow{3}{*}{$1935 / 1936$} & Fiú & 936 & 65,8 & 88 & 6,2 & 253 & 17,8 & 120 & 8,4 & 25 & 1,8 & 1422 \\
\hline & Lány & 233 & 57,7 & 34 & 8,4 & 74 & 18,3 & 61 & 15,1 & 2 & 0,5 & 404 \\
\hline & Összesen & 1169 & 64,0 & 122 & 6,7 & 327 & 17,9 & 181 & 9,9 & 27 & 1,5 & 1826 \\
\hline \multirow{3}{*}{$\begin{array}{l}\text { 1936/1937 } \\
\text { líceum }\end{array}$} & Fiú & 1416 & 65,2 & 157 & 7,2 & 342 & 15,7 & 238 & 11,0 & 20 & 0,9 & 2173 \\
\hline & Lány & 496 & 63,8 & 33 & 4,2 & 111 & 14,3 & 130 & 16,7 & 8 & 1,0 & 778 \\
\hline & Összesen & 1912 & 64,8 & 190 & 6,4 & 453 & 15,4 & 368 & 12,5 & 28 & 0,9 & 2951 \\
\hline
\end{tabular}

22. Az állami felsökereskedelmi iskolákba beiratkozott növendékek felekezeti megoszlása:

\begin{tabular}{|c|c|c|c|c|c|c|c|c|c|c|}
\hline \multirow{2}{*}{\multicolumn{2}{|c|}{\begin{tabular}{|c|} 
\\
Állami felsőkeres- \\
kedelmi iskolák
\end{tabular}}} & \multicolumn{9}{|c|}{ Beiratkozott növendékek felekezete } \\
\hline & & \multirow{2}{*}{ 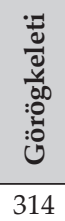 } & \multirow{2}{*}{ 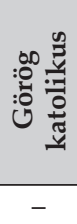 } & 䒕 & 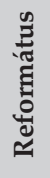 & 苞 & 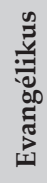 & \multirow{2}{*}{ 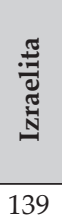 } & \multirow{2}{*}{$\begin{array}{l}\text { हैं } \\
\text { क्ञ } \\
681\end{array}$} & \multirow{2}{*}{ 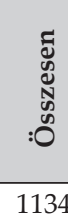 } \\
\hline \multirow{3}{*}{ 1921/1922 } & Fiú & & & & & & & & & \\
\hline & Lány & 42 & 26 & & & & & 46 & 61 & 175 \\
\hline & Összesen & 356 & 26 & & & & & 185 & 742 & 1309 \\
\hline \multirow{3}{*}{$1922 / 1923$} & Fiú & 468 & - & & & & & 183 & 352 & 1003 \\
\hline & Lány & 46 & 43 & & & & & 37 & 52 & 178 \\
\hline & Összesen & 514 & 43 & & & & & 220 & 404 & 1181 \\
\hline \multirow{3}{*}{ 1923/1924 } & Fiú & 582 & 88 & 185 & 10 & 63 & 23 & 180 & 4 & 1135 \\
\hline & Lány & 138 & 32 & 45 & 2 & 37 & 11 & 56 & - & 321 \\
\hline & Összesen & 720 & 120 & 230 & 12 & 100 & 34 & 236 & 4 & 1456 \\
\hline \multirow{3}{*}{$1924 / 1925$} & Fiú & 902 & 140 & 252 & 16 & 70 & 26 & 171 & 6 & 1583 \\
\hline & Lány & 215 & 95 & 62 & 8 & 30 & 25 & 59 & - & 494 \\
\hline & Összesen & 1117 & 235 & 314 & 24 & 100 & 51 & 230 & 6 & 2077 \\
\hline \multirow{3}{*}{$1925 / 1926$} & Fiú & 1251 & 240 & 287 & 11 & 72 & 24 & 159 & 7 & 2051 \\
\hline & Lány & 289 & 115 & 54 & 2 & 34 & 22 & 38 & 8 & 562 \\
\hline & Összesen & 1540 & 355 & 341 & 13 & 106 & 46 & 197 & 15 & 2613 \\
\hline
\end{tabular}




\begin{tabular}{|c|c|c|c|c|c|c|c|c|c|c|}
\hline \multirow{3}{*}{$1926 / 1927$} & Fiú & 1446 & 275 & 315 & 12 & 96 & 22 & 128 & 3 & 2297 \\
\hline & Lány & 414 & 168 & 43 & 3 & 52 & 18 & 37 & 15 & 750 \\
\hline & Összesen & 1860 & 443 & 358 & 15 & 148 & 40 & 165 & 18 & 3047 \\
\hline \multirow{3}{*}{$1927 / 1928$} & Fiú & 1613 & 321 & 377 & 12 & 94 & 28 & 138 & 6 & 2589 \\
\hline & Lány & 467 & 164 & 59 & 9 & 46 & 18 & 41 & - & 804 \\
\hline & Összesen & 2080 & 485 & 436 & 21 & 140 & 46 & 179 & 6 & 3393 \\
\hline \multirow{3}{*}{$1928 / 1929$} & Fiú & 1524 & 369 & 382 & 87 & 8 & 32 & 134 & 2 & 2538 \\
\hline & Lány & 490 & 167 & 55 & 18 & 30 & 14 & 47 & - & 821 \\
\hline & Összesen & 2014 & 536 & 437 & 105 & 38 & 46 & 181 & 2 & 3359 \\
\hline \multirow{3}{*}{$1930 / 1931$} & Fiú & 1858 & 534 & 419 & 10 & 120 & 25 & 161 & 3 & 3130 \\
\hline & Lány & 401 & 144 & 71 & 4 & 48 & 10 & 92 & 1 & 771 \\
\hline & Összesen & 2259 & 678 & 490 & 14 & 168 & 35 & 253 & 4 & 3901 \\
\hline \multirow{3}{*}{$1931 / 1932$} & Fiú & 1490 & 444 & 328 & 8 & 98 & 35 & 120 & 6 & 2529 \\
\hline & Lány & 324 & 118 & 58 & - & 32 & 15 & 78 & 1 & 626 \\
\hline & Összesen & 1814 & 562 & 386 & 8 & 130 & 50 & 198 & 7 & 3155 \\
\hline \multirow{3}{*}{$1932 / 1933$} & Fiú & 1051 & 312 & 262 & 5 & 82 & 30 & 108 & 15 & 1865 \\
\hline & Lány & 218 & 98 & 39 & 1 & 28 & 8 & 70 & 1 & 463 \\
\hline & Összesen & 1269 & 410 & 301 & 6 & 110 & 38 & 178 & 16 & 2328 \\
\hline \multirow{3}{*}{$1935 / 1936$} & Fiú & 706 & 227 & 243 & 8 & 92 & 20 & 120 & 6 & 1422 \\
\hline & Lány & 167 & 60 & 59 & 3 & 33 & 20 & 61 & 1 & 404 \\
\hline & Összesen & 873 & 287 & 302 & 11 & 125 & 40 & 181 & 7 & 1826 \\
\hline \multirow{3}{*}{$\begin{array}{l}\text { 1936/1937 } \\
\text { líceum }\end{array}$} & Fiú & 1003 & 409 & 317 & 148 & 21 & 35 & 238 & 2 & 2173 \\
\hline & Lány & 355 & 129 & 79 & 49 & 3 & 29 & 130 & 4 & 778 \\
\hline & Összesen & 1358 & 538 & 396 & 197 & 24 & 64 & 368 & 6 & 2951 \\
\hline
\end{tabular}

23. Az állami felsőkereskedelmi iskolák diákjainak felekezeti megoszlása, százalékban kifejezve:

\begin{tabular}{|c|c|c|c|c|c|c|c|c|}
\hline \multirow{2}{*}{\multicolumn{2}{|c|}{$\begin{array}{c}\text { Állami felsőkereske- } \\
\text { delmi iskolák }\end{array}$}} & \multicolumn{7}{|c|}{ Beiratkozott növendékek felekezete } \\
\hline & & \multirow{2}{*}{ 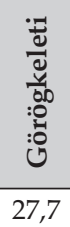 } & \multirow{2}{*}{ 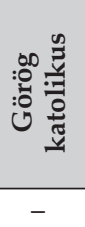 } & 䒕 & 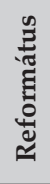 & 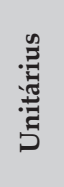 & 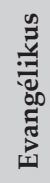 & \multirow{2}{*}{ 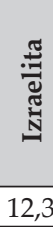 } \\
\hline \multirow{3}{*}{ 1921/1922 } & Fiú & & & & & & & \\
\hline & Lány & 24,0 & 14,9 & & & & & 26,3 \\
\hline & Összesen & 27,2 & 2,0 & & & & & 14,1 \\
\hline \multirow{3}{*}{ 1922/1923 } & Fiú & 46,7 & - & & & & & 18,2 \\
\hline & Lány & 25,8 & 24,2 & & & & & 20,8 \\
\hline & Összesen & 43,5 & 3,6 & & & & & 18,6 \\
\hline \multirow{3}{*}{ 1923/1924 } & Fiú & 51,3 & 7,8 & 16,3 & 0,9 & 5,6 & 2,0 & 15,9 \\
\hline & Lány & 43,0 & 10,0 & 14,0 & 0,6 & 11,5 & 3,4 & 17,4 \\
\hline & Összesen & 49,5 & 8,2 & 15,8 & 0,8 & 6,9 & 2,3 & 16,2 \\
\hline
\end{tabular}




\begin{tabular}{|c|c|c|c|c|c|c|c|c|}
\hline \multirow{3}{*}{$1924 / 1925$} & Fiú & 57,0 & 8,8 & 15,9 & 1,0 & 4,4 & 1,6 & 10,8 \\
\hline & Lány & 43,5 & 19,2 & 12,6 & 1,6 & 6,1 & 5,1 & 11,9 \\
\hline & Összesen & 53,8 & 11,3 & 15,1 & 1,2 & 4,8 & 2,5 & 11,1 \\
\hline \multirow{3}{*}{$1925 / 1926$} & Fiú & 61,0 & 11,7 & 14,0 & 0,5 & 3,5 & 1,2 & 7,8 \\
\hline & \begin{tabular}{|l|} 
Lány \\
\end{tabular} & 51,4 & 20,5 & 9,6 & 0,4 & 6,0 & 3,9 & 6,8 \\
\hline & Összesen & 58,9 & 13,6 & 13,1 & 0,5 & 4,1 & 1,8 & 7,5 \\
\hline \multirow{3}{*}{$1926 / 1927$} & Fiú & 63,0 & 12,0 & 13,7 & 0,5 & 4,2 & 1,0 & 5,6 \\
\hline & Lány & 55,2 & 22,4 & 5,7 & 0,4 & 6,9 & 2,4 & 4,9 \\
\hline & Összesen & 61,0 & 14,5 & 11,7 & 0,5 & 4,9 & 1,3 & 5,4 \\
\hline \multirow{3}{*}{$1927 / 1928$} & Fiú & 62,3 & 12,4 & 14,6 & 0,5 & 3,6 & 1,1 & 5,3 \\
\hline & Lány & 58,1 & 20,4 & 7,3 & 1,1 & 5,7 & 2,2 & 5,1 \\
\hline & Összesen & 61,3 & 14,3 & 12,8 & 0,6 & 4,1 & 1,4 & 5,3 \\
\hline \multirow{3}{*}{$1928 / 1929$} & Fiú & 60,0 & 14,5 & 15,1 & 3,4 & 0,3 & 1,3 & 5,3 \\
\hline & Lány & 59,7 & 20,3 & 6,7 & 2,2 & 3,7 & 1,7 & 5,7 \\
\hline & Összesen & 60,0 & 16,0 & 13,0 & 3,1 & 1,1 & 1,4 & 5,4 \\
\hline \multirow{3}{*}{$1930 / 1931$} & Fiú & 59,4 & 17,1 & 13,4 & 0,3 & 3,8 & 0,8 & 5,1 \\
\hline & Lány & 52,0 & 18,7 & 9,2 & 0,5 & 6,2 & 1,3 & 11,9 \\
\hline & Összesen & 57,9 & 17,4 & 12,6 & 0,4 & 4,3 & 0,9 & 6,5 \\
\hline \multirow{3}{*}{$1931 / 1932$} & Fiú & 58,9 & 17,6 & 13,0 & 0,3 & 3,9 & 1,4 & 4,7 \\
\hline & Lány & 51,8 & 18,8 & 9,3 & - & 5,1 & 2,4 & 12,5 \\
\hline & Összesen & 57,5 & 17,8 & 12,2 & 0,3 & 4,1 & 1,6 & 6,3 \\
\hline \multirow{3}{*}{$1932 / 1933$} & Fiú & 56,4 & 16,7 & 14,0 & 0,3 & 4,4 & 1,6 & 5,8 \\
\hline & Lány & 47,1 & 21,2 & 8,4 & 0,2 & 6,0 & 1,7 & 15,1 \\
\hline & Összesen & 54,5 & 17,6 & 12,9 & 0,3 & 4,7 & 1,6 & 7,6 \\
\hline \multirow{3}{*}{$1935 / 1936$} & Fiú & 49,6 & 16,0 & 17,1 & 0,6 & 6,5 & 1,4 & 8,4 \\
\hline & Lány & 41,3 & 14,9 & 14,6 & 0,7 & 8,2 & 5,0 & 15,1 \\
\hline & Összesen & 47,8 & 15,7 & 16,5 & 0,6 & 6,8 & 2,2 & 9,9 \\
\hline \multirow{3}{*}{$\begin{array}{l}\text { 1936/1937 } \\
\text { líceum }\end{array}$} & Fiú & 46,2 & 18,8 & 14,6 & 6,8 & 1,0 & 1,6 & 11,0 \\
\hline & Lány & 45,6 & 16,6 & 10,2 & 6,3 & 0,4 & 3,7 & 16,7 \\
\hline & Összesen & 46,0 & 18,2 & 13,4 & 6,7 & 0,8 & 2,2 & 12,5 \\
\hline
\end{tabular}

24. A kolozsvári I. Ferdinánd Tudományegyetem diákjainak nemi megoszlása fakultásonként, és a tanári kara 1921-1929 között:

\begin{tabular}{|c|c|c|c|c|c|c|}
\hline \multirow{3}{*}{\multicolumn{2}{|c|}{$\begin{array}{c}\text { I. Ferdinánd Tudományegyetem, } \\
\text { Kolozsvár }\end{array}$}} & \multicolumn{4}{|c|}{ Beiratkozott diákok } & \multirow{4}{*}{$\begin{array}{c}\text { Tanári } \\
\text { kar }\end{array}$} \\
\hline & & \multirow{3}{*}{$\begin{array}{l}\text { Férfi } \\
1196\end{array}$} & \multicolumn{2}{|c|}{ Nő } & \multirow{3}{*}{$\begin{array}{c}\text { Összesen } \\
1200 \\
\end{array}$} & \\
\hline & & & & $\%$ & & \\
\hline \multirow{6}{*}{$1921 / 1922$} & Jogi Kar & & 4 & 0,3 & & \\
\hline & Bölcsészkar & 295 & 164 & 35,7 & 459 & 33 \\
\hline & Természettudományi Kar & 86 & 45 & 34,4 & 131 & 87 \\
\hline & Orvosi Kar & 706 & 95 & 11,9 & 801 & \multirow{2}{*}{163} \\
\hline & Gyógyszerészeti Kar & 47 & 5 & 9,6 & 52 & \\
\hline & Összesen & 2330 & 313 & 11,8 & 2643 & 296 \\
\hline
\end{tabular}




\begin{tabular}{|c|c|c|c|c|c|c|}
\hline \multirow{6}{*}{$1922 / 1923$} & Jogi Kar & 1261 & 4 & 0,3 & 1265 & 13 \\
\hline & Bölcsészkar & 435 & 256 & 37,0 & 691 & 36 \\
\hline & Természettudományi Kar & 95 & 72 & 43,1 & 167 & 84 \\
\hline & Orvosi Kar & 625 & 81 & 11,5 & 706 & \multirow{2}{*}{160} \\
\hline & Gyógyszerészeti Kar & 58 & 13 & 18,3 & 71 & \\
\hline & Összesen & 2474 & 426 & 14,7 & 2900 & 293 \\
\hline \multirow{6}{*}{$1923 / 1924$} & Jogi Kar & 960 & - & - & 960 & 13 \\
\hline & Bölcsészkar & 190 & 138 & 42,1 & 328 & 33 \\
\hline & Természettudományi Kar & 105 & 90 & 46,2 & 195 & 86 \\
\hline & Orvosi Kar & 404 & 68 & 14,4 & 472 & \multirow{2}{*}{186} \\
\hline & Gyógyszerészeti Kar & 53 & 8 & 13,1 & 61 & \\
\hline & Összesen & 1712 & 304 & 15,1 & 2016 & 318 \\
\hline \multirow{6}{*}{$1924 / 1925$} & \begin{tabular}{|l|} 
Jogi Kar \\
\end{tabular} & 916 & 7 & 0,8 & 923 & 12 \\
\hline & Bölcsészkar & 223 & 178 & 44,4 & 401 & 32 \\
\hline & Természettudományi Kar & 103 & 111 & 51,9 & 214 & 86 \\
\hline & Orvosi Kar & 431 & 77 & 15,2 & 508 & \multirow{2}{*}{186} \\
\hline & Gyógyszerészeti Kar & 49 & 17 & 25,8 & 66 & \\
\hline & Összesen & 1722 & 390 & 18,5 & 2112 & 316 \\
\hline \multirow{6}{*}{$1925 / 1926$} & Jogi Kar & 1041 & 32 & 3,0 & 1073 & 12 \\
\hline & Bölcsészkar & 202 & 223 & 52,5 & 425 & 32 \\
\hline & Természettudományi Kar & 114 & 103 & 47,5 & 217 & 88 \\
\hline & Orvosi Kar & 391 & 89 & 18,5 & 480 & \multirow{2}{*}{193} \\
\hline & Gyógyszerészeti Kar & 62 & 35 & 36,1 & 97 & \\
\hline & Összesen & 1810 & 482 & 21,0 & 2292 & 325 \\
\hline \multirow{6}{*}{$1926 / 1927$} & Jogi Kar & 1158 & 28 & 2,4 & 1186 & 12 \\
\hline & Bölcsészkar & 218 & 289 & 57,0 & 507 & 35 \\
\hline & Természettudományi Kar & 138 & 96 & 41,0 & 234 & 95 \\
\hline & Orvosi Kar & 391 & 83 & 17,5 & 474 & \multirow{2}{*}{182} \\
\hline & Gyógyszerészeti Kar & 99 & 49 & 33,1 & 148 & \\
\hline & Összesen & 2004 & 545 & 21,4 & 2549 & 324 \\
\hline \multirow{6}{*}{$1927 / 1928$} & Jogi Kar & 1119 & 28 & 2,4 & 1147 & 17 \\
\hline & Bölcsészkar & 262 & 318 & 54,8 & 580 & 38 \\
\hline & Természettudományi Kar & 182 & 157 & 46,3 & 339 & 94 \\
\hline & Orvosi Kar & 434 & 75 & 14,7 & 509 & \multirow{2}{*}{197} \\
\hline & Gyógyszerészeti Kar & 93 & 44 & 32,1 & 137 & \\
\hline & Összesen & 2090 & 622 & 22,9 & 2712 & 346 \\
\hline \multirow{6}{*}{$1928 / 1929$} & Jogi Kar & 1051 & 32 & 3,0 & 1083 & 17 \\
\hline & Bölcsészkar & 334 & 375 & 52,9 & 709 & 36 \\
\hline & Természettudományi Kar & 262 & 193 & 42,4 & 455 & 93 \\
\hline & Orvosi Kar & 587 & 89 & 13,2 & 676 & \multirow{2}{*}{201} \\
\hline & Gyógyszerészeti Kar & 92 & 41 & 30,8 & 133 & \\
\hline & Összesen & 2326 & 730 & 23,9 & 3056 & 347 \\
\hline
\end{tabular}




\begin{tabular}{|l|l|c|c|c|c|c|}
\hline \multirow{4}{*}{$\mathbf{1 9 2 9 / 1 9 3 0}$} & 1479 & 40 & 2,6 & 1519 & 17 \\
\cline { 2 - 6 } & Jogi Kar & 320 & 388 & 54,8 & 708 & 55 \\
\cline { 2 - 6 } & Természkar & 320 & 268 & 45,6 & 588 & 99 \\
\cline { 2 - 6 } & Orvosi Kar & 674 & 93 & 12,1 & 767 & \multirow{2}{*}{178} \\
\cline { 2 - 6 } & Gyógyszerészeti Kar & 73 & 38 & 34,2 & 111 & \\
\cline { 2 - 6 } & Összesen & 2866 & 827 & 22,4 & 3693 & 349 \\
\hline
\end{tabular}

25. A kolozsvári (1940-1945 között nagyszebeni) I. Ferdinánd Tudományegyetem diákjainak nemi megoszlása fakultásonként és a tanári kara 1930-1941 között:

\begin{tabular}{|c|c|c|c|c|c|c|}
\hline \multirow{3}{*}{\multicolumn{2}{|c|}{$\begin{array}{l}\text { I. Ferdinánd Tudományegyetem, } \\
\text { Kolozsvár-Nagyszeben }\end{array}$}} & \multicolumn{4}{|c|}{ Beiratkozott diákok } & \multirow{4}{*}{$\begin{array}{c}\begin{array}{c}\text { Tanári } \\
\text { kar }\end{array} \\
17\end{array}$} \\
\hline & & \multirow{3}{*}{$\begin{array}{l}\text { Férfi } \\
1611\end{array}$} & \multicolumn{2}{|c|}{ Nő } & \multirow{3}{*}{$\begin{array}{c}\text { Összesen } \\
1714 \\
\end{array}$} & \\
\hline & & & & $\%$ & & \\
\hline \multirow{6}{*}{ 1930/1931 } & Jogi Kar & & 103 & 6,0 & & \\
\hline & Bölcsészkar & 363 & 401 & 52,5 & 764 & 56 \\
\hline & Természettudományi Kar & 294 & 295 & 50,1 & 589 & 99 \\
\hline & Orvosi Kar & 747 & 123 & 14,1 & 870 & \multirow{2}{*}{198} \\
\hline & Gyógyszerészeti Kar & 70 & 57 & 44,9 & 127 & \\
\hline & Összesen & 3085 & 979 & 24,1 & 4064 & 370 \\
\hline \multirow{6}{*}{ 1931/1932 } & Jogi Kar & 1578 & 113 & 6,7 & 1691 & 17 \\
\hline & Bölcsészkar & 318 & 366 & 53,5 & 684 & 60 \\
\hline & \begin{tabular}{|l|l} 
Természettudományi Kar \\
\end{tabular} & 222 & 241 & 52,1 & 463 & 101 \\
\hline & Orvosi Kar & 820 & 135 & 14,1 & 955 & \multirow{2}{*}{196} \\
\hline & Gyógyszerészeti Kar & 183 & 148 & 44,7 & 331 & \\
\hline & Összesen & 3121 & 1003 & 24,3 & 4124 & 374 \\
\hline \multirow{6}{*}{$1932 / 1933$} & Jogi Kar & 1742 & 71 & 3,9 & 1813 & 17 \\
\hline & \begin{tabular}{|l|} 
Bölcsészkar \\
\end{tabular} & 338 & 372 & 52,4 & 710 & 59 \\
\hline & Természettudományi Kar & 305 & 270 & 47,0 & 575 & 89 \\
\hline & Orvosi Kar & 838 & 146 & 14,8 & 984 & \multirow{2}{*}{179} \\
\hline & Gyógyszerészeti Kar & 219 & 168 & 43,4 & 387 & \\
\hline & Összesen & 3442 & 1027 & 23,0 & 4469 & 344 \\
\hline \multirow{6}{*}{$1933 / 1934$} & Jogi Kar & 1655 & 124 & 7,0 & 1779 & \\
\hline & \begin{tabular}{|l|} 
Bölcsészkar \\
\end{tabular} & 315 & 376 & 54,4 & 691 & \\
\hline & Természettudományi Kar & 316 & 238 & 43,0 & 554 & \\
\hline & Orvosi Kar & 861 & 164 & 16,0 & 1025 & \\
\hline & Gyógyszerészeti Kar & 223 & 173 & 43,7 & 396 & \\
\hline & Összesen & 3370 & 1075 & 24,2 & 4445 & \\
\hline \multirow{6}{*}{$1934 / 1935$} & Jogi Kar & 2050 & 134 & 6,1 & 2184 & \\
\hline & Bölcsészkar & 325 & 383 & 54,1 & 708 & \\
\hline & Természettudományi Kar & 244 & 159 & 39,5 & 403 & \\
\hline & Orvosi Kar & \multirow{2}{*}{830} & \multirow{2}{*}{175} & \multirow{2}{*}{17,4} & \multirow{2}{*}{1005} & \\
\hline & Gyógyszerészeti Kar & & & & & \\
\hline & Összesen & 3449 & 851 & 19,8 & 4300 & \\
\hline
\end{tabular}




\begin{tabular}{|c|c|c|c|c|c|c|}
\hline \multirow{6}{*}{$1935 / 1936$} & Jogi Kar & 1602 & 117 & 6,8 & 1719 & 25 \\
\hline & Bölcsészkar & 270 & 302 & 52,8 & 572 & 57 \\
\hline & Természettudományi Kar & 194 & 138 & 41,6 & 332 & 89 \\
\hline & \begin{tabular}{|l|} 
Orvosi Kar \\
\end{tabular} & \multirow{2}{*}{795} & \multirow{2}{*}{155} & \multirow{2}{*}{16,3} & \multirow{2}{*}{950} & \multirow{2}{*}{150} \\
\hline & Gyógyszerészeti Kar & & & & & \\
\hline & \begin{tabular}{|l|} 
Összesen \\
\end{tabular} & 2861 & 712 & 19,9 & 3573 & 321 \\
\hline \multirow{6}{*}{ 1936/1937 } & Jogi Kar & 1276 & 65 & 4,8 & 1341 & 25 \\
\hline & Bölcsészkar & 288 & 312 & 52,0 & 600 & 63 \\
\hline & Természettudományi Kar & 267 & 171 & 39,0 & 438 & 87 \\
\hline & Orvosi Kar & \multirow{2}{*}{720} & \multirow{2}{*}{140} & \multirow{2}{*}{16,3} & \multirow{2}{*}{860} & \multirow{2}{*}{163} \\
\hline & Gyógyszerészeti Kar & & & & & \\
\hline & Összesen & 2551 & 688 & 21,2 & 3239 & 338 \\
\hline \multirow{6}{*}{$1937 / 1938$} & Jogi Kar & 1234 & 87 & 6,6 & 1321 & \\
\hline & Bölcsészkar & 288 & 294 & 50,5 & 582 & \\
\hline & Természettudományi Kar & 228 & 129 & 36,1 & 357 & \\
\hline & Orvosi Kar & \multirow{2}{*}{733} & \multirow{2}{*}{162} & \multirow{2}{*}{18,1} & \multirow{2}{*}{895} & \\
\hline & Gyógyszerészeti Kar & & & & & \\
\hline & Összesen & 2483 & 672 & 21,3 & 3155 & \\
\hline \multirow{6}{*}{$1938 / 1939$} & Jogi Kar & 1265 & 99 & 7,3 & 1364 & \\
\hline & Bölcsészkar & 258 & 250 & 49,2 & 508 & \\
\hline & Természettudományi Kar & 225 & 99 & 30,6 & 324 & \\
\hline & Orvosi Kar & \multirow{2}{*}{718} & \multirow{2}{*}{180} & \multirow{2}{*}{20,0} & \multirow{2}{*}{898} & \\
\hline & Gyógyszerészeti Kar & & & & & \\
\hline & Összesen & 2466 & 628 & 20,3 & 3094 & \\
\hline \multirow{6}{*}{ 1941/1942 } & Jogi Kar & 623 & 67 & 9,7 & 690 & \\
\hline & Bölcsészkar & 138 & 132 & 48,9 & 270 & \\
\hline & Természettudományi Kar & 130 & 89 & 40,6 & 219 & \\
\hline & Orvosi Kar & \multirow{2}{*}{798} & \multirow{2}{*}{231} & \multirow{2}{*}{22,4} & \multirow{2}{*}{1029} & \\
\hline & Gyógyszerészeti Kar & & & & & \\
\hline & Összesen & 1689 & 519 & 23,5 & 2208 & \\
\hline
\end{tabular}

26. A kolozsvári I. Ferdinánd Tudományegyetemen államvizsgázott és doktorátust szerzett diákok száma fakultásonként, 1921-1928 között:

\begin{tabular}{|c|l|c|c|c|c|c|c|}
\hline \multicolumn{2}{c|}{$\begin{array}{c}\text { A kolozsvári I. Ferdinánd } \\
\text { Tudományegyetem }\end{array}$} & \multicolumn{2}{|c|}{ Államvizsgát tettek } & \multicolumn{3}{c|}{ Doktorok } \\
\cline { 2 - 9 } & Férfi & Nő & Összesen & Férfi & Nő & Összesen \\
\hline \multirow{5}{*}{$1921 / 1922$} & Jogi Kar & - & - & - & 117 & - & 117 \\
\cline { 2 - 9 } & Bölcsészkar & 3 & 1 & 4 & 3 & - & 3 \\
\cline { 2 - 9 } & Természettudományi Kar & 1 & - & 1 & 1 & - & 1 \\
\cline { 2 - 9 } & Orvosi Kar & - & - & - & 129 & 5 & 134 \\
\cline { 2 - 8 } & Gyógyszerészeti Kar & 29 & 5 & 34 & - & - & - \\
\cline { 2 - 8 } & Összesen & 33 & 6 & 39 & 250 & 5 & 255 \\
\hline
\end{tabular}




\begin{tabular}{|c|c|c|c|c|c|c|c|}
\hline \multirow{6}{*}{$1922 / 1923$} & Jogi Kar & - & - & - & 112 & - & 112 \\
\hline & Bölcsészkar & 4 & 4 & 8 & 3 & - & 3 \\
\hline & \begin{tabular}{|l|} 
Természettudományi Kar \\
\end{tabular} & 6 & - & 6 & 1 & 1 & 2 \\
\hline & Orvosi Kar & - & - & - & 106 & 4 & 110 \\
\hline & Gyógyszerészeti Kar & 14 & - & 14 & - & - & - \\
\hline & Összesen & 24 & 4 & 28 & 222 & 5 & 227 \\
\hline \multirow{6}{*}{ 1923/1924 } & Jogi Kar & - & - & - & 94 & - & 94 \\
\hline & Bölcsészkar & 8 & 6 & 14 & 6 & - & 6 \\
\hline & Természettudományi Kar & 11 & 4 & 15 & 3 & 1 & 4 \\
\hline & Orvosi Kar & - & - & - & 112 & 19 & 131 \\
\hline & Gyógyszerészeti Kar & 5 & - & 5 & - & - & - \\
\hline & Összesen & 24 & 10 & 34 & 215 & 20 & 235 \\
\hline \multirow{6}{*}{$1924 / 1925$} & Jogi Kar & 4 & 3 & 7 & - & - & - \\
\hline & \begin{tabular}{|l|} 
Bölcsészkar \\
\end{tabular} & - & - & - & 1 & - & 1 \\
\hline & Természettudományi Kar & - & - & - & - & - & - \\
\hline & Orvosi Kar & - & - & - & - & - & - \\
\hline & Gyógyszerészeti Kar & - & - & - & - & - & - \\
\hline & Összesen & 4 & 3 & 7 & 1 & - & 1 \\
\hline \multirow{6}{*}{ 1925/1926 } & Jogi Kar & 161 & - & 161 & 93 & 1 & 94 \\
\hline & Bölcsészkar & 25 & 19 & 44 & 1 & 1 & 2 \\
\hline & Természettudományi Kar & 13 & 11 & 24 & 2 & - & 2 \\
\hline & Orvosi Kar & - & - & - & 92 & 15 & 107 \\
\hline & Gyógyszerészeti Kar & 16 & 4 & 20 & - & - & - \\
\hline & Összesen & 215 & 34 & 249 & 188 & 17 & 205 \\
\hline \multirow{6}{*}{ 1926/1927 } & Jogi Kar & - & - & - & 118 & 1 & 119 \\
\hline & Bölcsészkar & 27 & 18 & 45 & 3 & 1 & 4 \\
\hline & Természettudományi Kar & 16 & 10 & 26 & 1 & - & 1 \\
\hline & Orvosi Kar & - & - & - & 83 & 12 & 95 \\
\hline & Gyógyszerészeti Kar & 12 & 4 & 16 & - & - & - \\
\hline & Összesen & 55 & 32 & 87 & 205 & 14 & 219 \\
\hline \multirow{6}{*}{$1927 / 1928$} & Jogi Kar & - & - & - & 96 & - & 96 \\
\hline & \begin{tabular}{|l|} 
Bölcsészkar \\
\end{tabular} & 36 & 28 & 64 & 2 & - & 2 \\
\hline & Természettudományi Kar & 26 & 30 & 56 & - & - & - \\
\hline & \begin{tabular}{|l|} 
Orvosi Kar \\
\end{tabular} & - & - & - & 56 & 14 & 70 \\
\hline & Gyógyszerészeti Kar & 18 & 12 & 30 & - & - & - \\
\hline & Összesen & 80 & 70 & 150 & 154 & 14 & 168 \\
\hline \multirow{6}{*}{ 1928/1929 } & Jogi Kar & 10 & - & 10 & 118 & - & 118 \\
\hline & \begin{tabular}{|l|} 
Bölcsészkar \\
\end{tabular} & 31 & 44 & 75 & 2 & - & 2 \\
\hline & Természettudományi Kar & 34 & 21 & 55 & 2 & 1 & 3 \\
\hline & Orvosi Kar & - & - & - & 35 & 18 & 53 \\
\hline & Gyógyszerészeti Kar & 19 & 12 & 31 & 2 & - & 2 \\
\hline & Összesen & 94 & 77 & 171 & 159 & 19 & 178 \\
\hline
\end{tabular}


27. A kolozsvári I. Ferdinánd Tudományegyetemen államvizsgázott és doktorátust szerzett diákok száma fakultásonként, 1930-1941 között:

\begin{tabular}{|c|c|c|c|c|c|c|c|}
\hline \multirow{2}{*}{\multicolumn{2}{|c|}{$\begin{array}{l}\text { A kolozsvári I. Ferdinánd } \\
\text { Tudományegyetem }\end{array}$}} & \multicolumn{3}{|c|}{ Államvizsgát tettek } & \multicolumn{3}{|c|}{ Doktorok } \\
\hline & & Férfi & Nő & Összesen & Férfi & Nő & Összesen \\
\hline \multirow{6}{*}{ 1930/1931 } & Jogi Kar & & & 19 & & & 96 \\
\hline & Bölcsészkar & & & 92 & & & 2 \\
\hline & Természettudományi Kar & & & 59 & & & 4 \\
\hline & Orvosi Kar & & & - & & & 29 \\
\hline & Gyógyszerészeti Kar & & & 36 & & & 1 \\
\hline & Összesen & & & 206 & & & 132 \\
\hline \multirow{6}{*}{ 1931/1932 } & Jogi Kar & & & 20 & & & 143 \\
\hline & Bölcsészkar & & & 106 & & & 4 \\
\hline & Természettudományi Kar & & & 68 & & & 5 \\
\hline & Orvosi Kar & & & - & & & 43 \\
\hline & Gyógyszerészeti Kar & & & 34 & & & 5 \\
\hline & Összesen & & & 228 & & & 200 \\
\hline \multirow{6}{*}{ 1932/1933 } & Jogi Kar & 6 & 2 & 8 & 122 & 7 & 129 \\
\hline & Bölcsészkar & 39 & 56 & 95 & 1 & - & 1 \\
\hline & Természettudományi Kar & 36 & 51 & 87 & 9 & - & 9 \\
\hline & Orvosi Kar & - & - & - & 73 & 11 & 84 \\
\hline & Gyógyszerészeti Kar & 22 & 12 & 34 & - & - & - \\
\hline & Összesen & 103 & 121 & 224 & 205 & 18 & 223 \\
\hline \multirow{6}{*}{$1933 / 1934$} & Jogi Kar & 13 & 1 & 14 & 164 & 9 & 173 \\
\hline & Bölcsészkar & 39 & 45 & 84 & 3 & - & 3 \\
\hline & Természettudományi Kar & 40 & 46 & 86 & 2 & - & 2 \\
\hline & Orvosi Kar & - & - & - & 89 & 9 & 98 \\
\hline & Gyógyszerészeti Kar & 22 & 15 & 37 & - & - & - \\
\hline & Összesen & 114 & 107 & 221 & 258 & 18 & 276 \\
\hline \multirow{6}{*}{$1934 / 1935$} & Jogi Kar & 31 & 4 & 35 & 185 & 12 & 197 \\
\hline & Bölcsészkar & 43 & 59 & 102 & 1 & - & 1 \\
\hline & Természettudományi Kar & 39 & 57 & 96 & 4 & - & 4 \\
\hline & Orvosi Kar & _ & - & - & 81 & 17 & 98 \\
\hline & Gyógyszerészeti Kar & - & - & - & 81 & 17 & 98 \\
\hline & Összesen & 113 & 120 & 233 & 271 & 29 & 300 \\
\hline \multirow{6}{*}{$1937 / 1938$} & Jogi Kar & 171 & 27 & 198 & 124 & 7 & 131 \\
\hline & Bölcsészkar & 49 & 59 & 108 & 3 & - & 3 \\
\hline & Természettudományi Kar & 21 & 28 & 49 & 8 & 1 & 9 \\
\hline & Orvosi Kar & - & & & & & \\
\hline & Gyógyszerészeti Kar & - & - & - & 118 & 20 & 138 \\
\hline & Összesen & 241 & 114 & 355 & 253 & 28 & 281 \\
\hline
\end{tabular}




\begin{tabular}{|c|c|c|c|c|c|c|c|}
\hline \multirow{6}{*}{$1938 / 1939$} & Jogi Kar & 202 & 18 & 220 & 131 & 7 & 138 \\
\hline & Bölcsészkar & 39 & 78 & 117 & 10 & 1 & 11 \\
\hline & Természettudományi Kar & 67 & 65 & 132 & 7 & 2 & 9 \\
\hline & Orvosi Kar & \multirow{2}{*}{-} & \multirow{2}{*}{-} & \multirow{2}{*}{-} & \multirow{2}{*}{132} & \multirow{2}{*}{33} & \multirow{2}{*}{165} \\
\hline & Gyógyszerészeti Kar & & & & & & \\
\hline & Összesen & 308 & 161 & 469 & 280 & 43 & 323 \\
\hline \multirow{6}{*}{$1941 / 1942$} & Jogi Kar & & & 170 & & & 11 \\
\hline & Bölcsészkar & & & 40 & & & 4 \\
\hline & Természettudományi Kar & & & 23 & & & 2 \\
\hline & Orvosi Kar & & & - & & & 97 \\
\hline & Gyógyszerészeti Kar & & & - & & & - \\
\hline & Összesen & & & 233 & & & 114 \\
\hline
\end{tabular}

28. Az I. Ferdinánd Tudományegyetem diákjainak nemzetiségi megoszlása fakultásonként, 1921-1928 között:

\begin{tabular}{|c|c|c|c|c|c|c|c|c|c|c|}
\hline \multirow{3}{*}{\multicolumn{2}{|c|}{$\begin{array}{c}\text { A kolozsvári I. Ferdinánd } \\
\text { Tudományegyetem }\end{array}$}} & \multicolumn{9}{|c|}{ Beiratkozott diákok } \\
\hline & & \multicolumn{2}{|c|}{ Román } & Magyar & Német & \multicolumn{2}{|c|}{ Zsidó } & \multicolumn{2}{|c|}{ Egyéb } & \multirow{2}{*}{ 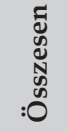 } \\
\hline & & & $\%$ & $\%$ & $\%$ & & $\%$ & & $\%$ & \\
\hline \multirow{6}{*}{ 1921/1922 } & Jogi Kar & 921 & 76,8 & & & 143 & 11,9 & 136 & 11,3 & 1200 \\
\hline & Bölcsészkar & 325 & 70,8 & & & 41 & 8,9 & 93 & 20,3 & 459 \\
\hline & $\begin{array}{l}\text { Természettudo- } \\
\text { mányi Kar }\end{array}$ & 104 & 79,4 & & & 12 & 9,2 & 15 & 11,5 & 131 \\
\hline & Orvosi Kar & 397 & 49,6 & & & 329 & 41,1 & 75 & 9,4 & 801 \\
\hline & $\begin{array}{l}\text { Gyógyszerésze- } \\
\text { ti Kar }\end{array}$ & 12 & 23,1 & & & 14 & 26,9 & 26 & 50,0 & 52 \\
\hline & Összesen & 1759 & 66,6 & & & 539 & 20,4 & 345 & 13,1 & 2643 \\
\hline \multirow{6}{*}{$1922 / 1923$} & Jogi Kar & 924 & 73,0 & & & 136 & 10,8 & 205 & 16,2 & 1265 \\
\hline & Bölcsészkar & 431 & 62,4 & & & 49 & 7,1 & 211 & 30,5 & 691 \\
\hline & $\begin{array}{l}\text { Természettudo- } \\
\text { mányi Kar }\end{array}$ & 123 & 73,7 & & & 17 & 10,2 & 27 & 16,2 & 167 \\
\hline & Orvosi Kar & 352 & 49,9 & & & 278 & 39,4 & 76 & 10,8 & 706 \\
\hline & $\begin{array}{l}\text { Gyógyszerésze- } \\
\text { ti Kar }\end{array}$ & 12 & 16,9 & & & 14 & 19,7 & 45 & 63,4 & 71 \\
\hline & Összesen & 1842 & 63,5 & & & 494 & 17,0 & 564 & 19,4 & 2900 \\
\hline \multirow{6}{*}{ 1923/1924 } & Jogi Kar & 752 & 78,3 & & & 88 & 9,2 & 120 & 12,5 & 960 \\
\hline & Bölcsészkar & 232 & 70,7 & & & \begin{tabular}{|l|}
14 \\
\end{tabular} & 4,3 & 82 & 25,0 & 328 \\
\hline & $\begin{array}{l}\text { Természettudo- } \\
\text { mányi Kar }\end{array}$ & 157 & 80,5 & & & 13 & 6,7 & 25 & 12,8 & 195 \\
\hline & Orvosi Kar & 343 & 72,7 & & & 100 & 21,2 & 29 & 6,1 & 472 \\
\hline & $\begin{array}{l}\text { Gyógyszerésze- } \\
\text { ti Kar }\end{array}$ & 11 & 18,0 & & & 8 & 13,1 & 42 & 68,9 & 61 \\
\hline & Összesen & 1495 & 74,2 & & & 223 & 11,1 & 298 & 14,8 & 2016 \\
\hline
\end{tabular}




\begin{tabular}{|c|c|c|c|c|c|c|c|c|c|c|c|c|}
\hline \multirow{6}{*}{$1924 / 1925$} & Jogi Kar & 745 & 80,7 & & & & & 41 & 4,4 & 137 & 14,8 & 923 \\
\hline & Bölcsészkar & 276 & 68,8 & & & & & 21 & 5,2 & 104 & 25,9 & 401 \\
\hline & $\begin{array}{l}\text { Természettudo- } \\
\text { mányi Kar }\end{array}$ & 181 & 84,6 & & & & & 6 & 2,8 & 27 & 12,6 & 214 \\
\hline & Orvosi Kar & 364 & 71,7 & & & & & 76 & 15,0 & 68 & 13,4 & 508 \\
\hline & $\begin{array}{l}\text { Gyógyszerésze- } \\
\text { ti Kar }\end{array}$ & 17 & 25,8 & & & & & 11 & 16,7 & 38 & 57,6 & 66 \\
\hline & Összesen & 1583 & 75,0 & & & & & 155 & 7,3 & 374 & 17,7 & 2112 \\
\hline \multirow{6}{*}{$1925 / 1926$} & Jogi Kar & 824 & 76,8 & 156 & 14,5 & 41 & 3,8 & 52 & 4,8 & - & - & 1073 \\
\hline & Bölcsészkar & 298 & 70,1 & 53 & 12,5 & 31 & 7,3 & 25 & 5,9 & 18 & 4,2 & 425 \\
\hline & $\begin{array}{l}\text { Természettudo- } \\
\text { mányi Kar }\end{array}$ & 182 & 83,9 & 21 & 9,7 & 8 & 3,7 & 6 & 2,8 & - & - & 217 \\
\hline & Orvosi Kar & 339 & 70,6 & 55 & 11,5 & 14 & 2,9 & 56 & 11,7 & 16 & 3,3 & 480 \\
\hline & $\begin{array}{l}\text { Gyógyszerésze- } \\
\text { ti Kar }\end{array}$ & 29 & 29,9 & 36 & 37,1 & 20 & 20,6 & 12 & 12,4 & - & - & 97 \\
\hline & Összesen & 1672 & 72,9 & 321 & 14,0 & 114 & 5,0 & 151 & 6,6 & 34 & 1,5 & 2292 \\
\hline \multirow{6}{*}{$1926 / 1927$} & Jogi Kar & 833 & 70,2 & 232 & 19,6 & 32 & 2,7 & 89 & 7,5 & - & - & 1186 \\
\hline & Bölcsészkar & 356 & 70,2 & 62 & 12,2 & 41 & 8,1 & 34 & 6,7 & 14 & 2,8 & 507 \\
\hline & $\begin{array}{l}\text { Természettudo- } \\
\text { mányi Kar }\end{array}$ & 190 & 81,2 & 26 & 11,1 & 14 & 6,0 & 2 & 0,9 & 2 & 0,9 & 234 \\
\hline & Orvosi Kar & 345 & 72,8 & 67 & 14,1 & 14 & 3,0 & 34 & 7,2 & 14 & 3,0 & 474 \\
\hline & $\begin{array}{l}\text { Gyógyszerésze- } \\
\text { ti Kar }\end{array}$ & 48 & 32,4 & 60 & 40,5 & 20 & 13,5 & 20 & 13,5 & - & - & 148 \\
\hline & Összesen & 1772 & 69,5 & 447 & 17,5 & 121 & 4,7 & 179 & 7,0 & 30 & 1,2 & 2549 \\
\hline \multirow{6}{*}{$1927 / 1928$} & Jogi Kar & 801 & 69,8 & 227 & 19,8 & 35 & 3,1 & 84 & 7,3 & - & - & 1147 \\
\hline & Bölcsészkar & 417 & 71,9 & 81 & 14,0 & 43 & 7,4 & 28 & 4,8 & 11 & 1,9 & 580 \\
\hline & $\begin{array}{l}\text { Természettudo- } \\
\text { mányi Kar }\end{array}$ & 274 & 80,8 & 45 & 13,3 & 14 & 4,1 & 5 & 1,5 & 1 & 0,3 & 339 \\
\hline & Orvosi Kar & 397 & 78,0 & 69 & 13,6 & 7 & 1,4 & 27 & 5,3 & 9 & 1,8 & 509 \\
\hline & $\begin{array}{l}\text { Gyógyszerésze- } \\
\text { ti Kar }\end{array}$ & 34 & 24,8 & 66 & 48,2 & 28 & 20,4 & 9 & 6,6 & - & - & 137 \\
\hline & Összesen & 1923 & 70,9 & 488 & 18,0 & 127 & 4,7 & 153 & 5,6 & 21 & 0,8 & 2712 \\
\hline \multirow{6}{*}{$1928 / 1929$} & Jogi Kar & 717 & 66,2 & 229 & 21,1 & 44 & 4,1 & 93 & 8,6 & - & - & 1083 \\
\hline & Bölcsészkar & 521 & 73,5 & 106 & 15,0 & 50 & 7,1 & 18 & 2,5 & 14 & 2,0 & 709 \\
\hline & $\begin{array}{l}\text { Természettudo- } \\
\text { mányi Kar }\end{array}$ & 374 & 82,2 & 60 & 13,2 & 14 & 3,1 & 6 & 1,3 & 1 & 0,2 & 455 \\
\hline & Orvosi Kar & 502 & 74,3 & 106 & 15,7 & 14 & 2,1 & 39 & 5,8 & 15 & 2,2 & 676 \\
\hline & $\begin{array}{l}\text { Gyógyszerésze- } \\
\text { ti Kar }\end{array}$ & 26 & 19,5 & 66 & 49,6 & 21 & 15,8 & 17 & 12,8 & 3 & 2,3 & 133 \\
\hline & Összesen & 2140 & 70,0 & 567 & 18,6 & 143 & 4,7 & 173 & 5,7 & 33 & 1,1 & 3056 \\
\hline
\end{tabular}


29. Az I. Ferdinánd Tudományegyetem diákjainak nemzetiségi megoszlása fakultásonként 1930-1941 között:

\begin{tabular}{|c|c|c|c|c|c|c|c|c|c|c|c|c|}
\hline \multirow{3}{*}{\multicolumn{2}{|c|}{ Kolozsvári Egyetem }} & \multicolumn{11}{|c|}{ Beiratkozott diákok } \\
\hline & & \multicolumn{2}{|c|}{ Román } & \multicolumn{2}{|c|}{ Magyar } & \multicolumn{2}{|c|}{ Német } & \multicolumn{2}{|c|}{ Zsidó } & \multicolumn{2}{|c|}{ Egyéb } & \multirow{2}{*}{ 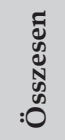 } \\
\hline & & & $\%$ & & $\%$ & & $\%$ & & $\%$ & & $\%$ & \\
\hline \multirow{6}{*}{$1930 / 1931$} & Jogi Kar & 1108 & 64,6 & 393 & 22,9 & 68 & 4,0 & 145 & 8,5 & - & - & 1714 \\
\hline & Bölcsészkar & 513 & & 150 & 19,6 & 57 & 7,5 & 26 & 3,4 & 18 & 2,4 & 764 \\
\hline & $\begin{array}{l}\begin{array}{l}\text { Természettu- } \\
\text { dományi Kar }\end{array} \\
\end{array}$ & 447 & 75,9 & 88 & 14,9 & 41 & 7,0 & 6 & 1,0 & 7 & 1,2 & 589 \\
\hline & Orvosi Kar & 579 & 66,6 & 169 & 19,4 & 27 & 3,1 & 92 & 10,6 & 3 & 0,3 & 870 \\
\hline & $\begin{array}{l}\text { Gyó } \\
\text { szeti }\end{array}$ & 38 & 29,9 & 42 & 33,1 & 14 & 11,0 & 32 & 25,2 & 1 & 0,8 & 127 \\
\hline & Összesen & 685 & 66,1 & 842 & 20,7 & 207 & 5,1 & 301 & 7,4 & 29 & 0,7 & 4064 \\
\hline \multirow{6}{*}{ 1931/1932 } & & 1061 & & 379 & 22,4 & 95 & 5,6 & 151 & 8,9 & 5 & 0,3 & 1691 \\
\hline & \begin{tabular}{|l|} 
Bölcsészkar \\
\end{tabular} & 420 & 61,4 & 169 & 24,7 & 53 & 7,7 & 35 & 5,1 & 7 & 1,0 & 684 \\
\hline & & 316 & 68,3 & 107 & 23,1 & 25 & 5,4 & 13 & 2,8 & 2 & 0,4 & 463 \\
\hline & Orvosi Kar & 630 & 66,0 & 171 & 17,9 & 28 & 2,9 & 114 & 11,9 & 12 & 1,3 & 955 \\
\hline & $\begin{array}{l}\text { Gyóg } \\
\text { szeti }\end{array}$ & 113 & 34,1 & 109 & 32,9 & 30 & 9,1 & 75 & 22,7 & 4 & 1,2 & 331 \\
\hline & Ös & 2540 & & 935 & 22,7 & 231 & 5,6 & 388 & 9,4 & 30 & 0,7 & 4124 \\
\hline \multirow{6}{*}{$1932 / 1933$} & Jogi & 1182 & 65,2 & 309 & 17,0 & 178 & 9,8 & 143 & 7,9 & 1 & 0,1 & 1813 \\
\hline & Bölcsészkar & 395 & 556 & 207 & 29,2 & 62 & 7,5 & 47 & 6,6 & 8 & 1,1 & 710 \\
\hline & $\begin{array}{l}\begin{array}{l}\text { Természettu- } \\
\text { dományi Kar }\end{array} \\
\end{array}$ & 364 & 63,3 & 153 & 26,6 & 30 & 5,2 & 22 & 3,8 & 6 & 1,0 & 575 \\
\hline & Orvosi Kar & 45 & 65,3 & 1 & 15,8 & 32 & 3,3 & 142 & 14,4 & 2 & 2 & 984 \\
\hline & \begin{tabular}{|l|}
$\begin{array}{l}\text { Gyógyszer } \\
\text { szeti Kar }\end{array}$ \\
\end{tabular} & 138 & 35,7 & 98 & 25,3 & 52 & 13,4 & 93 & 24,0 & 6 & 1,6 & 387 \\
\hline & Összesen & 2722 & 60,9 & 922 & 20,6 & 345 & 7,7 & 447 & 10,0 & 33 & 0,7 & 4469 \\
\hline \multirow{6}{*}{ 1933/1934 } & Jogi Kar & 1078 & 60,6 & 441 & 24,8 & 99 & 5,6 & 152 & 8,5 & 9 & 0,5 & 1779 \\
\hline & Bölcsészkar & 364 & 52,7 & 207 & 30,0 & 65 & 9,4 & 44 & 6,4 & 11 & 1,6 & 691 \\
\hline & $\begin{array}{l}\text { Természettu- } \\
\text { dományi Kar }\end{array}$ & 293 & 52,9 & 201 & 36,3 & 35 & 6,3 & 17 & 3,1 & 8 & 1,4 & 554 \\
\hline & Orvosi Kar & 000 & 63,7 & 154 & 15,0 & 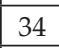 & ה טדו & 156 & 15,2 & 28 & 2,7 & 1025 \\
\hline & \begin{tabular}{|l|} 
Gyógyszeré- \\
szeti Kar
\end{tabular} & 130 & 32,8 & 124 & 31,3 & 51 & 12,9 & 87 & 22,0 & 4 & 1,0 & 396 \\
\hline & Összesen & 2518 & 56,6 & 1127 & 25,4 & 284 & 6,4 & 456 & 10,3 & 60 & 1,3 & 4445 \\
\hline
\end{tabular}




\begin{tabular}{|c|c|c|c|c|c|c|c|c|c|c|c|c|}
\hline \multirow{6}{*}{$1934 / 1935$} & Jogi Kar & 1507 & 69,0 & 459 & 21,0 & 60 & 2,7 & 157 & 7,2 & 1 & 0,0 & 2184 \\
\hline & Bölcsészkar & 399 & 56,4 & 196 & 27,7 & 65 & 9,2 & 40 & 5,6 & 8 & 1,1 & 708 \\
\hline & $\begin{array}{l}\text { Természettu- } \\
\text { dományi Kar }\end{array}$ & 219 & 54,3 & 142 & 35,2 & 18 & 4,5 & 21 & 5,2 & 3 & 0,7 & 403 \\
\hline & Orvosi Kar & \multirow[b]{2}{*}{632} & \multirow[b]{2}{*}{62,9} & \multirow[b]{2}{*}{148} & \multirow[b]{2}{*}{14,7} & \multirow[b]{2}{*}{34} & \multirow[b]{2}{*}{3,4} & \multirow[b]{2}{*}{178} & \multirow[b]{2}{*}{17,7} & \multirow[b]{2}{*}{13} & \multirow[b]{2}{*}{1,3} & \multirow[b]{2}{*}{1005} \\
\hline & $\begin{array}{l}\text { Gyógyszeré- } \\
\text { szeti Kar }\end{array}$ & & & & & & & & & & & \\
\hline & \begin{tabular}{|l|} 
Összesen \\
\end{tabular} & 2757 & 64,1 & 945 & 22,0 & 177 & 4,1 & 396 & 9,2 & 25 & 0,6 & 4300 \\
\hline \multirow{6}{*}{$1935 / 1936$} & Jogi Kar & 1195 & 69,5 & 370 & 21,5 & 44 & 2,6 & 101 & 5,9 & 9 & 0,5 & 1719 \\
\hline & Bölcsészkar & 329 & 57,5 & 145 & 25,3 & 54 & 9,4 & 33 & 5,8 & 11 & 1,9 & 572 \\
\hline & $\begin{array}{l}\text { Természettu- } \\
\text { dományi Kar }\end{array}$ & 194 & 58,4 & 95 & 28,6 & 20 & 6,0 & 16 & 4,8 & 7 & 2,1 & 332 \\
\hline & Orvos & \multirow[b]{2}{*}{555} & \multirow[b]{2}{*}{58,4} & \multirow[b]{2}{*}{123} & \multirow[b]{2}{*}{12,9} & \multirow[b]{2}{*}{45} & \multirow[b]{2}{*}{4,7} & \multirow[b]{2}{*}{203} & \multirow[b]{2}{*}{21,4} & \multirow[b]{2}{*}{24} & \multirow[b]{2}{*}{2,5} & \multirow[b]{2}{*}{950} \\
\hline & $\begin{array}{l}\begin{array}{l}\text { Gyógyszeré- } \\
\text { szeti Kar }\end{array} \\
\end{array}$ & & & & & & & & & & & \\
\hline & Összesen & 2273 & 63,6 & 733 & 20,5 & 163 & 4,6 & 353 & 9,9 & 51 & 1,4 & 3573 \\
\hline \multirow{6}{*}{$1936 / 1937$} & Jogi & 980 & 73,1 & 226 & 16,9 & 53 & 4,0 & 74 & 5,5 & 8 & 0,6 & 1341 \\
\hline & Bölcsészkar & 362 & 60,3 & 128 & 21,3 & 51 & 8,5 & 42 & 7,0 & 17 & 2,8 & 600 \\
\hline & \begin{tabular}{|l|} 
Természettu- \\
dományi Kar
\end{tabular} & 261 & 59,6 & 116 & 26,5 & 21 & 4,8 & 28 & 6,4 & 12 & 2,7 & 438 \\
\hline & Orvosi Kar & \multirow[b]{2}{*}{498} & \multirow[b]{2}{*}{57,9} & \multirow[b]{2}{*}{110} & & & & & & & & \\
\hline & $\begin{array}{l}\text { Gyógyszeré- } \\
\text { szeti Kar }\end{array}$ & & & & 12,8 & 42 & 4,9 & 177 & 20,6 & 33 & 3,8 & 860 \\
\hline & Összesen & 2101 & 64,9 & 580 & 17,9 & 167 & 5,2 & 321 & 9,9 & 70 & 2,2 & 3239 \\
\hline & Jogi Kar & 965 & 73,1 & 235 & 17,8 & 40 & 3,0 & 69 & 5,2 & 12 & 0,9 & 1321 \\
\hline & Bölcsészkar & 362 & 62,2 & 120 & 20,6 & 43 & 7,4 & 46 & 7,9 & 11 & 1,9 & 582 \\
\hline & $\begin{array}{l}\text { Természettu- } \\
\text { dományi Kar }\end{array}$ & 213 & 59,7 & 102 & 28,6 & 9 & 2,5 & 26 & 7,3 & 7 & 2,0 & 357 \\
\hline 15 & Orvosi Kar & & & & & & & & & & & \\
\hline & $\begin{array}{l}\text { Gyógyszeré- } \\
\text { szeti Kar }\end{array}$ & 519 & 58,0 & 109 & 12,2 & 40 & 4,5 & 155 & 17,3 & 72 & 8,0 & 895 \\
\hline & Összesen & 2059 & 65,3 & 566 & 17,9 & 132 & 4,2 & 296 & 9,4 & 102 & 3,2 & 3155 \\
\hline & Jogi Kar & 980 & 71,8 & 268 & 19,6 & 43 & 3,2 & 66 & 4,8 & 7 & 0,5 & 1364 \\
\hline & Bölcsészkar & 321 & 63,2 & 95 & 18,7 & 37 & 7,3 & 44 & \begin{tabular}{|l|}
8,7 \\
\end{tabular} & 11 & 2,2 & 508 \\
\hline & $\begin{array}{l}\text { Természettu- } \\
\text { dományi Kar }\end{array}$ & 199 & 61,4 & 78 & 24,1 & 9 & 2,8 & 34 & 10,5 & 4 & 1,2 & 324 \\
\hline 193 & Orvosi Kar & & & & & & & & & & & \\
\hline & $\begin{array}{l}\text { Gyógyszeré- } \\
\text { szeti Kar }\end{array}$ & 529 & 58,9 & 112 & 12,5 & 58 & 6,5 & 142 & 15,8 & 57 & 6,3 & 898 \\
\hline & Összesen & 029 & 65,6 & 553 & 17,9 & 147 & 4,8 & 286 & 9,2 & 79 & 2,6 & \begin{tabular}{|l|}
3094 \\
\end{tabular} \\
\hline
\end{tabular}




\begin{tabular}{|c|c|c|c|c|c|c|c|c|c|c|c|c|}
\hline \multirow{6}{*}{ 1941/1942 } & Jogi Kar & 664 & 96,2 & 5 & 0,7 & 17 & 2,5 & - & - & 4 & 0,6 & 690 \\
\hline & Bölcsészkar & 252 & 93,3 & 1 & 0,4 & 17 & 6,3 & - & - & - & - & 270 \\
\hline & $\begin{array}{l}\text { Természettu- } \\
\text { dományi Kar }\end{array}$ & 184 & 84,0 & 9 & 4,1 & 21 & 9,6 & - & - & 5 & 2,3 & 219 \\
\hline & Orvosi Kar & \multirow[b]{2}{*}{980} & \multirow[b]{2}{*}{95,2} & \multirow[b]{2}{*}{3} & \multirow[b]{2}{*}{0,3} & \multirow[b]{2}{*}{45} & \multirow[b]{2}{*}{4,4} & \multirow[b]{2}{*}{-} & \multirow[b]{2}{*}{ - } & \multirow[b]{2}{*}{1} & \multirow[b]{2}{*}{0,1} & \multirow[b]{2}{*}{1029} \\
\hline & $\begin{array}{l}\text { Gyógyszeré- } \\
\text { szeti Kar }\end{array}$ & & & & & & & & & & & \\
\hline & Összesen & 2080 & 94,2 & 18 & 0,8 & 100 & 4,5 & - & - & 10 & 0,5 & 2208 \\
\hline
\end{tabular}

30. A kolozsvári I. Ferdinánd Tudományegyetem diákjainak felekezeti megoszlása fakultásonként, 1921-1928 között:

\begin{tabular}{|c|c|c|c|c|c|c|c|c|c|c|}
\hline I. Ferdiná & nd Tudományegyetem & 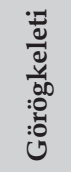 & 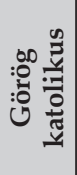 & 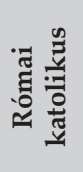 & 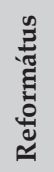 & 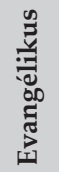 & & 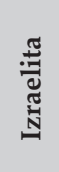 & 离 & 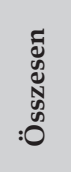 \\
\hline & Jogi Kar & 500 & & & & & & 143 & 557 & 1200 \\
\hline & \begin{tabular}{|l|} 
Bölcsészkar \\
\end{tabular} & 193 & & & & & & 41 & 225 & 459 \\
\hline 1921/1922 & \begin{tabular}{|l} 
Természettudományi \\
Kar \\
\end{tabular} & 86 & & & & & & 12 & 33 & 131 \\
\hline & Orvosi Kar & 318 & & & & & & 329 & 154 & 801 \\
\hline & Gyógyszerészeti Kar & 12 & & & & & & 14 & 26 & 52 \\
\hline & Összesen & 1109 & & & & & & 539 & 995 & 2643 \\
\hline & Jogi Kar & 476 & & & & & & 136 & 653 & 1265 \\
\hline & Bölcsészkar & 294 & & & & & & 49 & 348 & 691 \\
\hline $1922 / 1923$ & \begin{tabular}{|l} 
Természettudományi \\
Kar
\end{tabular} & 91 & & & & & & 17 & 59 & 167 \\
\hline & Orvosi Kar & 309 & & & & & & 278 & 119 & 706 \\
\hline & Gyógyszerészeti Kar & 12 & & & & & & 14 & 45 & 71 \\
\hline & Összesen & 1182 & & & & & & 494 & 1224 & 2900 \\
\hline & Jogi Kar & 421 & & & & & & 88 & 451 & 960 \\
\hline & \begin{tabular}{|l|} 
Bölcsészkar \\
\end{tabular} & 152 & & & & & & 14 & 162 & 328 \\
\hline $1923 / 1924$ & $\begin{array}{l}\text { Természettudományi } \\
\text { Kar } \\
\end{array}$ & 118 & & & & & & 13 & 64 & 195 \\
\hline & Orvosi Kar & 249 & & & & & & 100 & 123 & 472 \\
\hline & Gyógyszerészeti Kar & 11 & & & & & & 8 & 42 & 61 \\
\hline & Összesen & 951 & & & & & & 223 & 842 & 2016 \\
\hline
\end{tabular}




\begin{tabular}{|c|c|c|c|c|c|c|c|c|c|c|}
\hline \multirow{6}{*}{$1924 / 1925$} & Jogi Kar & 370 & & & & & & 41 & 512 & 923 \\
\hline & Bölcsészkar & 184 & & & & & & 21 & 196 & 401 \\
\hline & $\begin{array}{l}\text { Természettudományi } \\
\text { Kar }\end{array}$ & 130 & & & & & & 6 & 78 & 214 \\
\hline & Orvosi Kar & 260 & & & & & & 76 & 172 & 508 \\
\hline & Gyógyszerészeti Kar & 17 & & & & & & 11 & 38 & 66 \\
\hline & Összesen & 961 & & & & & & 155 & 996 & 2112 \\
\hline \multirow{6}{*}{$1925 / 1926$} & Jogi Kar & 419 & 405 & 86 & 57 & 41 & 13 & 52 & - & 1073 \\
\hline & Bölcsészkar & 205 & 106 & 47 & 21 & 20 & 1 & 25 & - & 425 \\
\hline & \begin{tabular}{|l}
$\begin{array}{l}\text { Természettudományi } \\
\text { Kar }\end{array}$ \\
\end{tabular} & 124 & 58 & 15 & 5 & 7 & 1 & 6 & 1 & 217 \\
\hline & Orvosi Kar & 245 & 97 & 42 & 21 & 13 & 6 & 56 & - & 480 \\
\hline & Gyógyszerésze & 18 & 8 & 35 & 15 & 5 & 4 & 12 & - & 97 \\
\hline & Összesen & 1011 & 674 & 225 & 119 & 86 & 25 & 151 & 1 & 2292 \\
\hline \multirow{6}{*}{ 1926/1927 } & Jogi Kar & 427 & 406 & 131 & 82 & 32 & 19 & 89 & - & 1186 \\
\hline & Bölcsészkar & 244 & 125 & 46 & 25 & 31 & 1 & 34 & 1 & 507 \\
\hline & $\begin{array}{l}\text { Természettudományi } \\
\text { Kar }\end{array}$ & 121 & 66 & 24 & 4 & 14 & 2 & 2 & 1 & 234 \\
\hline & Orvosi Kar & 185 & 174 & 37 & 36 & 7 & 1 & 34 & - & 474 \\
\hline & Gyógyszerészeti Kar & 26 & 22 & 42 & 22 & 14 & 2 & 20 & - & 148 \\
\hline & Összesen & 1003 & 793 & 280 & 169 & 98 & 25 & 179 & 2 & 2549 \\
\hline \multirow{6}{*}{$1927 / 1928$} & Jogi Kar & 405 & 396 & 140 & 74 & 35 & 13 & 84 & - & 1147 \\
\hline & Bölcsészkar & 271 & 153 & 48 & 39 & 38 & 3 & 28 & - & 580 \\
\hline & \begin{tabular}{|l} 
Természettudományi \\
Kar
\end{tabular} & 171 & 100 & 30 & 15 & 13 & 4 & 5 & 1 & 339 \\
\hline & Orvosi Kar & 264 & 142 & 36 & 17 & 7 & 16 & 27 & - & 509 \\
\hline & Gyógyszerészeti Kar & 21 & 13 & 39 & 12 & 28 & 15 & 9 & - & 137 \\
\hline & Összesen & 1132 & 804 & 293 & 157 & 121 & 51 & 153 & 1 & 2712 \\
\hline \multirow{6}{*}{ 1928/1929 } & Jogi Kar & 339 & 378 & 131 & 87 & 44 & 11 & 93 & - & 1083 \\
\hline & Bölcsészkar & 350 & 181 & 62 & 54 & 40 & 4 & 18 & - & 709 \\
\hline & $\begin{array}{l}\text { Természettudományi } \\
\text { Kar }\end{array}$ & 233 & 139 & 41 & 16 & 13 & 6 & 6 & 1 & 455 \\
\hline & Orvosi Kar & 307 & 205 & 49 & 31 & 14 & 30 & 39 & 1 & 676 \\
\hline & Gyógyszerészeti Kar & 15 & 11 & 33 & 16 & 21 & 20 & 17 & - & 133 \\
\hline & Összesen & 1244 & 914 & 316 & 204 & 132 & 71 & 173 & 2 & 3056 \\
\hline
\end{tabular}


31. A kolozsvári I. Ferdinánd Tudományegyetem diákjainak felekezeti megoszlása fakultásonként, 1921-1928 között, százalékban kifejezve:

\begin{tabular}{|c|c|c|c|c|c|c|c|c|}
\hline I. Ferdiná & nd Tudományegyetem & 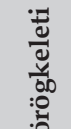 & 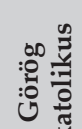 & 䒕 & 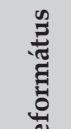 & 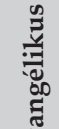 & 苞 & 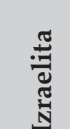 \\
\hline & Jogi Kar & 41,7 & & & & & & 11,9 \\
\hline & \begin{tabular}{|l|} 
Bölcsészkar \\
\end{tabular} & 42,0 & & & & & & 8,9 \\
\hline $1921 / 1922$ & \begin{tabular}{|l} 
Természettudományi \\
Kar \\
\end{tabular} & 65,6 & & & & & & 9,2 \\
\hline & Orvosi Kar & 39,7 & & & & & & 41,1 \\
\hline & Gyógyszerészeti Kar & 23,1 & & & & & & 26,9 \\
\hline & Összesen & 42,0 & & & & & & 20,4 \\
\hline & Jogi Kar & 37,6 & & & & & & 10,8 \\
\hline & \begin{tabular}{|l|} 
Bölcsészkar \\
\end{tabular} & 42,5 & & & & & & 7,1 \\
\hline $1922 / 1923$ & \begin{tabular}{|l} 
Természettudományi \\
Kar \\
\end{tabular} & 54,5 & & & & & & 10,2 \\
\hline & Orvosi Kar & 43,8 & & & & & & 39,4 \\
\hline & \begin{tabular}{|l|} 
Gyógyszerészeti Kar \\
\end{tabular} & 16,9 & & & & & & 19,7 \\
\hline & \begin{tabular}{|l|} 
Összesen \\
\end{tabular} & 40,8 & & & & & & 17,0 \\
\hline & Jogi Kar & 43,9 & & & & & & 9,2 \\
\hline & \begin{tabular}{|l|} 
Bölcsészkar \\
\end{tabular} & 46,3 & & & & & & 4,3 \\
\hline $1923 / 1924$ & \begin{tabular}{|l} 
Természettudományi \\
Kar
\end{tabular} & 60,5 & & & & & & 6,7 \\
\hline & \begin{tabular}{|l|} 
Orvosi Kar \\
\end{tabular} & 52,8 & & & & & & 21,2 \\
\hline & \begin{tabular}{|l|} 
Gyógyszerészeti Kar \\
\end{tabular} & 18,0 & & & & & & 13,1 \\
\hline & Összesen & 47,2 & & & & & & 11,1 \\
\hline & Jogi Kar & 40,1 & & & & & & 4,4 \\
\hline & \begin{tabular}{|l|} 
Bölcsészkar \\
\end{tabular} & 45,9 & & & & & & 5,2 \\
\hline $1924 / 1925$ & \begin{tabular}{|l} 
Természettudományi \\
Kar \\
\end{tabular} & 60,7 & & & & & & 2,8 \\
\hline & \begin{tabular}{|l|} 
Orvosi Kar \\
\end{tabular} & 51,2 & & & & & & 15,0 \\
\hline & Gyógyszerészeti Kar & 25,8 & & & & & & 16,7 \\
\hline & Összesen & 45,5 & & & & & & 7,3 \\
\hline & Jogi Kar & 39,0 & 37,7 & 8,0 & 5,3 & 3,8 & 1,2 & 4,8 \\
\hline & \begin{tabular}{|l|} 
Bölcsészkar \\
\end{tabular} & 48,2 & 24,9 & 11,1 & 4,9 & 4,7 & 0,2 & 5,9 \\
\hline $1925 / 1926$ & \begin{tabular}{|l} 
Természettudományi \\
Kar
\end{tabular} & 57,1 & 26,7 & 6,9 & 2,3 & 3,2 & 0,5 & 2,8 \\
\hline & \begin{tabular}{|l|} 
Orvosi Kar \\
\end{tabular} & 51,0 & 20,2 & 8,8 & 4,4 & 2,7 & 1,3 & 11,7 \\
\hline & \begin{tabular}{|l} 
Gyógyszerészeti Kar \\
\end{tabular} & 18,6 & 8,2 & 36,1 & 15,5 & 5,2 & 4,1 & 12,4 \\
\hline & Összesen & 44,1 & 29,4 & 9,8 & 5,2 & 3,8 & 1,1 & 6,6 \\
\hline
\end{tabular}




\begin{tabular}{|c|c|c|c|c|c|c|c|c|}
\hline \multirow{6}{*}{$1926 / 1927$} & Jogi Kar & 36,0 & 34,2 & 11,0 & 6,9 & 2,7 & 1,6 & 7,5 \\
\hline & Bölcsészkar & 48,1 & 24,7 & 9,1 & 4,9 & 6,1 & 0,2 & 6,7 \\
\hline & $\begin{array}{l}\text { Természettudományi } \\
\text { Kar }\end{array}$ & 51,7 & 28,2 & 10,3 & 1,7 & 6,0 & 0,9 & 0,9 \\
\hline & Orvosi Kar & 39,0 & 36,7 & 7,8 & 7,6 & 1,5 & 0,2 & 7,2 \\
\hline & Gyógyszerészeti Kar & 17,6 & 14,9 & 28,4 & 14,9 & 9,5 & 1,4 & 13,5 \\
\hline & Összesen & 39,3 & 31,1 & 11,0 & 6,6 & 3,8 & 1,0 & 7,0 \\
\hline \multirow{6}{*}{$1927 / 1928$} & Jogi Kar & 35,3 & 34,5 & 12,2 & 6,5 & 3,1 & 1,1 & 7,3 \\
\hline & Bölcsészkar & 46,7 & 26,4 & 8,3 & 6,7 & 6,6 & 0,5 & 4,8 \\
\hline & $\begin{array}{l}\text { Természettudományi } \\
\text { Kar } \\
\end{array}$ & 50,4 & 29,5 & 8,8 & 4,4 & 3,8 & 1,2 & 1,5 \\
\hline & Orvosi Kar & 51,9 & 27,9 & 7,1 & 3,3 & 1,4 & 3,1 & 5,3 \\
\hline & Gyógyszerészeti Kar & 15,3 & 9,5 & 28,5 & 8,8 & 20,4 & 10,9 & 6,6 \\
\hline & \begin{tabular}{|l|} 
Összesen \\
\end{tabular} & 41,7 & 29,6 & 10,8 & 5,8 & 4,5 & 1,9 & 5,6 \\
\hline \multirow{6}{*}{$1928 / 1929$} & Jogi Kar & 31,3 & 34,9 & 12,1 & 8,0 & 4,1 & 1,0 & 8,6 \\
\hline & Bölcsészkar & 49,4 & 25,5 & 8,7 & 7,6 & 5,6 & 0,6 & 2,5 \\
\hline & $\begin{array}{l}\text { Természettudományi } \\
\text { Kar }\end{array}$ & 51,2 & 30,5 & 9,0 & 3,5 & 2,9 & 1,3 & 1,3 \\
\hline & Orvosi Kar & 45,4 & 30,3 & 7,2 & 4,6 & 2,1 & 4,4 & 5,8 \\
\hline & Gyógyszerészeti Kar & 11,3 & 8,3 & 24,8 & 12,0 & 15,8 & 15,0 & 12,8 \\
\hline & Összesen & 40,7 & 29,9 & 10,3 & 6,7 & 4,3 & 2,3 & 5,7 \\
\hline
\end{tabular}

32. A kolozsvári I. Ferdinánd Tudományegyetem diákjainak felekezeti megoszlása fakultásonként, 1930-1941 között:

\begin{tabular}{|c|c|c|c|c|c|c|c|c|c|c|}
\hline I. Ferdinár & Id Tudományegyetem & 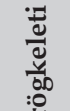 & 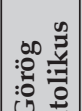 & 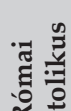 & 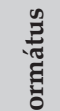 & 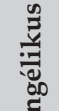 & 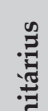 & 莺 & $\sum_{00}^{00}$ & 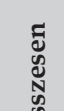 \\
\hline & Jogi Kar & 519 & 589 & 205 & 155 & 68 & 33 & 145 & - & 1714 \\
\hline & Bölcsészkar & 310 & 197 & 103 & 76 & 46 & 6 & 26 & - & 764 \\
\hline 1930/1931 & \begin{tabular}{|l}
$\begin{array}{l}\text { Természettudomá- } \\
\text { nyi Kar }\end{array}$ \\
\end{tabular} & 271 & 169 & 77 & 30 & 31 & 4 & 7 & - & 589 \\
\hline & Orvosi Kar & 445 & 140 & 109 & 56 & 23 & 2 & 92 & 3 & 870 \\
\hline & Gyógyszeré & 21 & 21 & 25 & 13 & 12 & 3 & 32 & - & 127 \\
\hline & Összesen & 1566 & 1116 & 519 & 330 & 180 & 48 & 302 & 3 & 4064 \\
\hline & Jogi Kar & 507 & 523 & 229 & 166 & 70 & 30 & 166 & - & 1691 \\
\hline & Bölcsészkar & 264 & 150 & 105 & 86 & 36 & 7 & 36 & - & 684 \\
\hline 1931/1932 & $\begin{array}{l}\text { Természettudomá- } \\
\text { nyi Kar }\end{array}$ & 172 & 131 & 87 & 44 & 11 & 5 & 13 & - & 463 \\
\hline & Orvosi Kar & 473 & 165 & 101 & 65 & 26 & 9 & 114 & 2 & 955 \\
\hline & Gyógyszerészeti Kar & 79 & 35 & 77 & 36 & 24 & 3 & 75 & 2 & 331 \\
\hline & Összesen & 1495 & 1004 & 599 & 397 & 167 & 54 & 404 & 4 & 4124 \\
\hline
\end{tabular}




\begin{tabular}{|c|c|c|c|c|c|c|c|c|c|c|}
\hline \multirow{6}{*}{$1932 / 1933$} & Jogi Kar & 592 & 591 & 236 & 140 & 82 & 28 & 143 & 1 & 1813 \\
\hline & Bölcsészkar & 239 & 152 & 123 & 104 & 31 & 13 & 47 & 1 & 710 \\
\hline & \begin{tabular}{|l|}
$\begin{array}{l}\text { Természettudomá- } \\
\text { nyi Kar }\end{array}$ \\
\end{tabular} & 206 & 147 & 112 & 61 & 19 & 8 & 22 & - & 575 \\
\hline & Orvosi Kar & 484 & 163 & 86 & 70 & 27 & 10 & 141 & 3 & 984 \\
\hline & Gyógyszerészeti Kar & 103 & 34 & 81 & 30 & 37 & 6 & 93 & 3 & 387 \\
\hline & Összesen & 1624 & 1087 & 638 & 405 & 196 & 65 & 446 & 8 & 4469 \\
\hline \multirow{6}{*}{ 1933/1934 } & Jogi Kar & 558 & 511 & 249 & 189 & 87 & 34 & 150 & 1 & 1779 \\
\hline & Bölcsészkar & 230 & 136 & 131 & 99 & 37 & 14 & 43 & 1 & 691 \\
\hline & $\begin{array}{l}\text { Természettudomá- } \\
\text { nyi Kar }\end{array}$ & 174 & 118 & 124 & 87 & 27 & 7 & 17 & - & 554 \\
\hline & Orvosi Kar & 504 & 164 & 90 & 64 & 29 & 12 & 156 & 6 & 1025 \\
\hline & Gyógyszerészeti Kar & 93 & 38 & 94 & 34 & 41 & 7 & 87 & 2 & 396 \\
\hline & Összesen & 1559 & 967 & 688 & 473 & 221 & 74 & 453 & 10 & 4445 \\
\hline \multirow{6}{*}{$1934 / 1935$} & Jogi Kar & 800 & 707 & 260 & 167 & 60 & 32 & 157 & 1 & 2184 \\
\hline & Bölcsészkar & 235 & 153 & 127 & 97 & 41 & 13 & 40 & 2 & 708 \\
\hline & $\begin{array}{l}\text { Természettudomá- } \\
\text { nyi Kar }\end{array}$ & 125 & 93 & 89 & 56 & 11 & 6 & 21 & 2 & 403 \\
\hline & Orvosi Kar & \multirow{2}{*}{471} & \multirow{2}{*}{163} & \multirow{2}{*}{96} & \multirow{2}{*}{58} & \multirow{2}{*}{29} & \multirow{2}{*}{8} & \multirow{2}{*}{178} & \multirow{2}{*}{2} & \multirow{2}{*}{1005} \\
\hline & Gyógyszerészeti Kar & & & & & & & & & \\
\hline & Összesen & 1631 & 1116 & 572 & 378 & 141 & 59 & 396 & 7 & 4300 \\
\hline \multirow{6}{*}{$1935 / 1936$} & Jogi Kar & 639 & 567 & 212 & 132 & 42 & 26 & 101 & - & 1719 \\
\hline & Bölcsészkar & 211 & 120 & 98 & 68 & 34 & 8 & 33 & - & 572 \\
\hline & \begin{tabular}{|l} 
Természettudomá- \\
nyi Kar
\end{tabular} & 114 & 78 & 66 & 13 & 39 & 6 & 16 & - & 332 \\
\hline & Orvosi Kar & \multirow{2}{*}{426} & \multirow{2}{*}{149} & \multirow{2}{*}{85} & \multirow{2}{*}{48} & \multirow{2}{*}{27} & \multirow{2}{*}{10} & \multirow{2}{*}{203} & \multirow{2}{*}{2} & \multirow{2}{*}{950} \\
\hline & Gyógyszerésze & & & & & & & & & \\
\hline & Összesen & 1390 & 914 & 461 & 261 & 142 & 50 & 353 & 2 & 3573 \\
\hline \multirow{6}{*}{$1936 / 1937$} & Jogi Kar & 529 & 436 & 152 & 104 & 25 & 21 & 74 & - & 1341 \\
\hline & Bölcsészkar & 220 & 149 & 81 & 65 & 35 & 6 & 42 & 2 & 600 \\
\hline & $\begin{array}{l}\text { Természettudomá- } \\
\text { nyi Kar }\end{array}$ & 163 & 106 & 74 & 45 & 12 & 8 & 28 & 2 & 438 \\
\hline & Orvosi Kar & \multirow{2}{*}{410} & \multirow{2}{*}{119} & \multirow[b]{2}{*}{88} & & & & & & \\
\hline & Gyógyszerészeti Kar & & & & 34 & 26 & 6 & $1 / 7$ & - & 860 \\
\hline & Összesen & 1322 & 810 & 395 & 248 & 98 & 41 & 321 & 4 & 3239 \\
\hline & Jogi Kar & 549 & 417 & 156 & 91 & 17 & 18 & 69 & 4 & 1321 \\
\hline & Bölcsészkar & 223 & 136 & 81 & 62 & 25 & 8 & 46 & 1 & 582 \\
\hline 1937/1938 & \begin{tabular}{|l}
$\begin{array}{l}\text { Természettudomá- } \\
\text { nyi Kar }\end{array}$ \\
\end{tabular} & 137 & 75 & 65 & 42 & 7 & 5 & 26 & - & 357 \\
\hline & Orvosi Kar & & & & 8 & & 5 & & 1 & \\
\hline & Gyógyszerészeti Kar & 4 & 1 & 91 & 30 & 19 & 0 & 100 & 1 & \\
\hline & Összesen & 1358 & 765 & 393 & 233 & 68 & 36 & 296 & 6 & 3155 \\
\hline
\end{tabular}




\begin{tabular}{|c|c|c|c|c|c|c|c|c|c|c|}
\hline \multirow{6}{*}{$1938 / 1939$} & Jogi Kar & 578 & 420 & 195 & 64 & 26 & 16 & 65 & - & 1364 \\
\hline & Bölcsészkar & 204 & 116 & 75 & 38 & 25 & 7 & 43 & - & 508 \\
\hline & $\begin{array}{l}\text { Természettudomá- } \\
\text { nyi Kar }\end{array}$ & 124 & 77 & 45 & 32 & 5 & 7 & 34 & - & 324 \\
\hline & Orvosi Kar & \multirow{2}{*}{461} & \multirow{2}{*}{123} & \multirow{2}{*}{103} & \multirow{2}{*}{39} & \multirow{2}{*}{23} & \multirow{2}{*}{6} & \multirow{2}{*}{142} & \multirow{2}{*}{1} & \multirow{2}{*}{898} \\
\hline & Gyógyszerészeti Kar & & & & & & & & & \\
\hline & Összesen & 1367 & 736 & 418 & 173 & 79 & 36 & 284 & 1 & 3094 \\
\hline \multirow{6}{*}{$1941 / 1942$} & Jogi Kar & 450 & 217 & 11 & 4 & 8 & - & - & & 690 \\
\hline & Bölcsészkar & 172 & 77 & 10 & 1 & 10 & - & - & - & 270 \\
\hline & $\begin{array}{l}\text { Természettudomá- } \\
\text { nyi Kar }\end{array}$ & 129 & 55 & 29 & 3 & 3 & - & - & - & 219 \\
\hline & Orvosi Kar & \multirow{2}{*}{719} & \multirow{2}{*}{259} & \multirow{2}{*}{31} & \multirow{2}{*}{3} & \multirow{2}{*}{14} & \multirow{2}{*}{-} & \multirow{2}{*}{ - } & \multirow{2}{*}{3} & \multirow{2}{*}{1029} \\
\hline & Gyógyszerészeti Kar & & & & & & & & & \\
\hline & Összesen & 1470 & 608 & 81 & 11 & 35 & - & - & 3 & 2208 \\
\hline
\end{tabular}

33. A kolozsvári I. Ferdinánd Tudományegyetem diákjainak felekezeti megoszlása fakultásonként, 1930-1941 között, százalékban kifejezve:

\begin{tabular}{|c|c|c|c|c|c|c|c|c|}
\hline I. Ferdir & ánd Tudományegyetem & 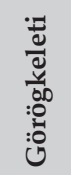 & 苟 & 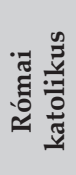 & 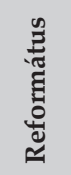 & 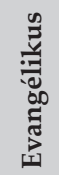 & & 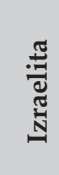 \\
\hline & Jogi Kar & 30,3 & 34,4 & 12,0 & 9,0 & 4,0 & 1,9 & 8,5 \\
\hline & Bölcsészkar & 40,6 & 25,8 & 13,5 & 9,9 & 6,0 & 0,8 & 3,4 \\
\hline 102 & Természettudományi Kar & 46,0 & 28,7 & 13,1 & 5,1 & 5,3 & 0,7 & 1,2 \\
\hline $1930 \%$ & Orvosi Kar & 51,1 & 16,1 & 12,5 & 6,4 & 2,6 & 0,2 & 10,6 \\
\hline & Gyógyszeré & 16,5 & 16,5 & 19,7 & 10,2 & 9,4 & 2,4 & 25,2 \\
\hline & Összesen & 38,5 & 27,5 & 12,8 & 8,1 & 4,4 & 1,2 & 7,4 \\
\hline & Jogi Kar & 30,0 & 30,9 & 13,5 & 9,8 & 4,1 & 1,8 & 9,8 \\
\hline & Bölcsészkar & 38,6 & 21,9 & 15,4 & 12,6 & 5,3 & 1,0 & 5,3 \\
\hline 193 & \begin{tabular}{|l|} 
Természettud \\
\end{tabular} & 37,1 & 28,3 & 18,8 & 9,5 & 2,4 & 1,1 & 2,8 \\
\hline & Orvosi Kar & 49,5 & 17,3 & 10,6 & 6,8 & 2,7 & 0,9 & 11,9 \\
\hline & Gyógyszerés & 23,9 & 10,6 & 23,3 & 10,9 & 7,3 & 0,9 & 22,7 \\
\hline & Összesen & 36,3 & 24,3 & 14,5 & 9,6 & 4,0 & 1,3 & 9,8 \\
\hline & Jogi Kar & 32,7 & 32,6 & 13,0 & 7,7 & 4,5 & 1,5 & 7,9 \\
\hline & Bölcsészkar & 33,7 & 21,4 & 17,3 & 14,6 & 4,4 & 1,8 & 6,6 \\
\hline & Természettudományi Kar & 35,8 & 25,6 & 19,5 & 10,6 & 3,3 & 1,4 & 3,8 \\
\hline $1932 / 193$ & Orvosi Kar & 49,2 & 16,6 & 8,7 & 7,1 & 2,7 & 1,0 & 14,3 \\
\hline & Gyógyszerészeti Kar & 26,6 & 8,8 & 20,9 & 7,8 & 9,6 & 1,6 & 24,0 \\
\hline & Összesen & 36,3 & 24,3 & 14,3 & 9,1 & 4,4 & 1,5 & 10,0 \\
\hline
\end{tabular}




\begin{tabular}{|c|c|c|c|c|c|c|c|c|}
\hline \multirow{6}{*}{$1933 / 1934$} & Jogi Kar & 31,4 & 28,7 & 14,0 & 10,6 & 4,9 & 1,9 & 8,4 \\
\hline & Bölcsészkar & 33,3 & 19,7 & 19,0 & 14,3 & 5,4 & 2,0 & 6,2 \\
\hline & Természettudományi Kar & 31,4 & 21,3 & 22,4 & 15,7 & 4,9 & 1,3 & 3,1 \\
\hline & Orvosi Kar & 49,2 & 16,0 & 8,8 & 6,2 & 2,8 & 1,2 & 15,2 \\
\hline & Gyógyszerészeti Kar & 23,5 & 9,6 & 23,7 & 8,6 & 10,4 & 1,8 & 22,0 \\
\hline & Összesen & 35,1 & 21,8 & 15,5 & 10,6 & 5,0 & 1,7 & 10,2 \\
\hline \multirow{6}{*}{$1934 / 1935$} & Jogi Kar & 36,6 & 32,4 & 11,9 & 7,6 & 2,7 & 1,5 & 7,2 \\
\hline & \begin{tabular}{|l|} 
Bölcsészkar \\
\end{tabular} & 33,2 & 21,6 & 17,9 & 13,7 & 5,8 & 1,8 & 5,6 \\
\hline & Természettudományi Kar & 31,0 & 23,1 & 22,1 & 13,9 & 2,7 & 1,5 & 5,2 \\
\hline & Orvosi Kar & \multirow{2}{*}{46,9} & \multirow{2}{*}{16,2} & \multirow{2}{*}{9,6} & \multirow{2}{*}{5,8} & \multirow{2}{*}{2,9} & \multirow{2}{*}{0,8} & \multirow{2}{*}{17,7} \\
\hline & Gyógyszerészeti Kar & & & & & & & \\
\hline & Összesen & 37,9 & 26,0 & 13,3 & 8,8 & 3,3 & 1,4 & 9,2 \\
\hline \multirow{6}{*}{$1935 / 1936$} & Jogi Kar & 37,2 & 33,0 & 12,3 & 7,7 & 2,4 & 1,5 & 5,9 \\
\hline & Bölcsészkar & 36,9 & 21,0 & 17,1 & 11,9 & 5,9 & 1,4 & 5,8 \\
\hline & Természettudományi Kar & 34,3 & 23,5 & 19,9 & 3,9 & 11,7 & 1,8 & 4,8 \\
\hline & Orvosi Kar & \multirow{2}{*}{44,8} & \multirow{2}{*}{15,7} & \multirow{2}{*}{8,9} & \multirow{2}{*}{5,1} & \multirow{2}{*}{2,8} & \multirow{2}{*}{1,1} & \multirow{2}{*}{21,4} \\
\hline & Gyógyszerészeti Kar & & & & & & & \\
\hline & Összesen & 38,9 & 25,6 & 12,9 & 7,3 & 4,0 & 1,4 & 9,9 \\
\hline \multirow{6}{*}{$1936 / 1937$} & Jogi Kar & 39,4 & 32,5 & 11,3 & 7,8 & 1,9 & 1,6 & 5,5 \\
\hline & Bölcsészkar & 36,7 & 24,8 & 13,5 & 10,8 & 5,8 & 1,0 & 7,0 \\
\hline & Természettudományi Kar & 37,2 & 24,2 & 16,9 & 10,3 & 2,7 & 1,8 & 6,4 \\
\hline & Orvosi Kar & \multirow{2}{*}{47,7} & \multirow{2}{*}{13,8} & \multirow{2}{*}{10,2} & \multirow{2}{*}{4,0} & \multirow{2}{*}{3,0} & \multirow{2}{*}{0,7} & 206 \\
\hline & Gyógyszerészeti Kar & & & & & & & 20,0 \\
\hline & Összesen & 40,8 & 25,0 & 12,2 & 7,7 & 3,0 & 1,3 & 9,9 \\
\hline & Jogi Kar & 41,6 & 31,6 & 11,8 & 6,9 & 1,3 & 1,4 & 5,2 \\
\hline & Bölcsészkar & 38,3 & 23,4 & 13,9 & 10,7 & 4,3 & 1,4 & 7,9 \\
\hline & Természettudományi Kar & 38,4 & 21,0 & 18,2 & 11,8 & 2,0 & 1,4 & 7,3 \\
\hline $1937 / 1938$ & Orvosi Kar & & 153 & 102 & 42 & 21 & 06 & 173 \\
\hline & Gyógyszerészeti Kar & & 10 & 10,2 & 4,2 & 2,1 & 0,0 & $1 /, 3$ \\
\hline & Összesen & 43 & 24,2 & 12,5 & 7,4 & 2,2 & 1,1 & 9,4 \\
\hline & Jogi Kar & 42,4 & 30,8 & 14,3 & 4,7 & 1,9 & 1,2 & 4,8 \\
\hline & \begin{tabular}{|l|} 
Bölcsészkar \\
\end{tabular} & 40,2 & 22,8 & 14,8 & 7,5 & 4,9 & 1,4 & 8,5 \\
\hline & Természettudományi Kar & 38,3 & 23,8 & 13,9 & 9,9 & 1,5 & 2,2 & 10,5 \\
\hline $1938 / 1939$ & Orvosi Kar & & & & & & & \\
\hline & Gyógyszerészeti Kar & 51,3 & 13,7 & 11,5 & 4,3 & 2,6 & 0,7 & 15,8 \\
\hline & Összesen & 44,2 & 23,8 & 13,5 & 5,6 & 2,6 & 1,2 & 9,2 \\
\hline & Jogi Kar & 65,2 & 31,4 & 1,6 & 0,6 & 1,2 & - & - \\
\hline & Bölcsészkar & 63,7 & 28,5 & 3,7 & 0,4 & 3,7 & - & - \\
\hline & Természettudományi Kar & 58,9 & 25,1 & 13,2 & 1,4 & 1,4 & - & - \\
\hline $1941 / 1942$ & Orvosi Kar & & & 30 & 03 & & - & - \\
\hline & Gyógyszerészeti Kar & 69,9 & 20,2 & 3,0 & 0,3 & 1,4 & - & - \\
\hline & Összesen & 66,6 & 27,5 & 3,7 & 0,5 & 1,6 & - & - \\
\hline
\end{tabular}


34. Az erdélyi alsó és középfokú oktatásban részt vevö román nemzetiségü diákok megoszlása iskolafenntartók szerint 1928/1929-ben: ${ }^{1}$

\begin{tabular}{|l|c|c|c|c|c|}
\hline \multirow{2}{*}{ Románok } & \multicolumn{2}{|c|}{ Állami szektor } & \multicolumn{2}{c|}{$\begin{array}{c}\text { Egyházi és } \\
\text { magánszektor }\end{array}$} & \multirow{2}{*}{ Összesen } \\
\cline { 2 - 5 } & & $\%$ & & $\%$ & \\
\hline Óvodák & 19244 & 98,9 & 219 & 1,1 & 19463 \\
\hline Elemi iskolák & 313128 & 99,7 & 987 & 0,3 & 314115 \\
\hline Tanítóképzők & 6102 & 100,0 & 0 & 0,0 & 6102 \\
\hline $\begin{array}{l}\text { Gimnáziumok és I. fokú } \\
\text { leány-középiskolák }\end{array}$ & 3978 & 99,8 & 7 & 0,2 & 3985 \\
\hline $\begin{array}{l}\text { Líceumok és II. fokú } \\
\text { leány-középiskolák }\end{array}$ & 12946 & 99,3 & 87 & 0,7 & 13033 \\
\hline $\begin{array}{l}\text { Kereskedelmi iskolák } \\
\text { (elemi és felsőkereske- } \\
\text { delmi) }\end{array}$ & 2909 & 98,7 & 38 & 1,3 & 2947 \\
\hline $\begin{array}{l}\text { Ipariskolák, szakiskolák, } \\
\text { háztartási iskolák }\end{array}$ & 4287 & 100,0 & 0 & 0,0 & 4287 \\
\hline Összesen & 362594 & 99,6 & 1338 & 0,4 & 363932 \\
\hline
\end{tabular}

35. Az erdélyi alsó és középfokú oktatásban részt vevö magyar nemzetiségü diákok megoszlása iskolafenntartók szerint 1928/1929-ben: ${ }^{2}$

\begin{tabular}{|l|c|c|c|c|c|}
\hline \multirow{2}{*}{\multicolumn{1}{|c|}{ Magyarok }} & \multicolumn{2}{|c|}{ Állami szektor } & \multicolumn{2}{c|}{$\begin{array}{c}\text { Egyházi és } \\
\text { magánszektor }\end{array}$} & \multirow{2}{*}{ Összesen } \\
\cline { 2 - 5 } & & $\%$ & & $\%$ & \\
\hline Óvodák & 12642 & 89,3 & 1507 & 10,7 & 14149 \\
\hline Elemi iskolák & 69658 & 52,2 & 63792 & 47,8 & 133450 \\
\hline Tanítóképzók & 142 & 15,6 & 768 & 84,4 & 910 \\
\hline $\begin{array}{l}\text { Gimnáziumok és I. fokú } \\
\text { leány-középiskolák }\end{array}$ & 1398 & 37,8 & 2298 & 62,2 & 3696 \\
\hline $\begin{array}{l}\text { Líceumok és II. fokú } \\
\text { leány-középiskolák }\end{array}$ & 1733 & 27,5 & 4578 & 72,5 & 6311 \\
\hline $\begin{array}{l}\text { Kereskedelmi iskolák (ele- } \\
\text { mi és felsőkereskedelmi) }\end{array}$ & 416 & 47,3 & 463 & 52,7 & 879 \\
\hline $\begin{array}{l}\text { Ipariskolák, szakiskolák, } \\
\text { háztartási iskolák }\end{array}$ & 216 & 100,0 & 0 & 0,0 & 216 \\
\hline Összesen & 86205 & 54,0 & 73406 & 46,0 & 159611 \\
\hline
\end{tabular}

\footnotetext{
${ }^{1}$ A kimutatás nem teljes, ugyanis nem tartalmazza a mezőgazdasági iskolák adatait, valamint a magántanulók és felnőttképző tanfolyamok diákjainak számát!

${ }^{2}$ A kimutatás nem teljes, ugyanis nem tartalmazza a mezőgazdasági iskolák adatait, valamint a magántanulók és felnőttképző tanfolyamok diákjainak számát!
} 
36. Az erdélyi alsó és középfokú oktatásban részt vevö német nemzetiségü diákok megoszlása iskolafenntartók szerint 1928/1929-ben: ${ }^{3}$

\begin{tabular}{|l|c|c|c|c|c|}
\hline \multirow{2}{*}{ Németek } & \multicolumn{2}{|c|}{ Állami szektor } & \multicolumn{2}{c|}{$\begin{array}{c}\text { Egyházi és } \\
\text { magánszektor }\end{array}$} & \multirow{2}{*}{ Összesen } \\
\cline { 2 - 5 } & & $\%$ & & $\%$ & \\
\hline Óvodák & 5606 & 50,6 & 5475 & 49,4 & 11081 \\
\hline Elemi iskolák & 19924 & 35,8 & 35717 & 64,2 & 55641 \\
\hline Tanítóképzők & 45 & 11,6 & 343 & 88,4 & 388 \\
\hline $\begin{array}{l}\text { Gimnáziumok és I. fokú } \\
\text { leány-középiskolák }\end{array}$ & 614 & 29,1 & 1497 & 70,9 & 2111 \\
\hline $\begin{array}{l}\text { Líceumok és II. fokú } \\
\text { leány-középiskolák }\end{array}$ & 862 & 33,1 & 1745 & 66,9 & 2607 \\
\hline $\begin{array}{l}\text { Kereskedelmi iskolák } \\
\text { (elemi és felsőkereske- } \\
\text { delmi) }\end{array}$ & 218 & 61,8 & 135 & 38,2 & 353 \\
\hline $\begin{array}{l}\text { Ipariskolák, szakiskolák, } \\
\text { háztartási iskolák }\end{array}$ & 77 & 100,0 & 0 & 0,0 & 77 \\
\hline Összesen & 27346 & 37,8 & 44912 & 62,2 & 72258 \\
\hline
\end{tabular}

37. Az erdélyi alsó és középfokú oktatásban részt vevö zsidó nemzetiségü diákok megoszlása iskolafenntartók szerint 1928/1929-ben: ${ }^{4}$

\begin{tabular}{|l|c|c|c|c|c|}
\hline \multirow{2}{*}{\multicolumn{1}{|c|}{ Zsidók }} & \multicolumn{2}{|c|}{ Állami szektor } & \multicolumn{2}{c|}{$\begin{array}{c}\text { Egyházi és } \\
\text { magánszektor }\end{array}$} & \multirow{2}{*}{ Összesen } \\
\cline { 2 - 5 } & & $\%$ & & $\%$ & \\
\hline Óvodák & 2058 & 89,7 & 236 & 10,3 & 2294 \\
\hline Elemi iskolák & 11974 & 72,7 & 4487 & 27,3 & 16461 \\
\hline Tanítóképzők & 11 & 78,6 & 3 & 21,4 & 14 \\
\hline $\begin{array}{l}\text { Gimnáziumok és I. fokú } \\
\text { leány-középiskolák }\end{array}$ & 475 & 54,9 & 390 & 45,1 & 865 \\
\hline $\begin{array}{l}\text { Líceumok és II. fokú } \\
\text { leány-középiskolák }\end{array}$ & 1564 & 73,7 & 557 & 26,3 & 2121 \\
\hline $\begin{array}{l}\text { Kereskedelmi iskolák } \\
\text { (elemi és felsőkereske- } \\
\text { delmi) }\end{array}$ & 217 & 47,0 & 245 & 53,0 & 462 \\
\hline $\begin{array}{l}\text { Ipariskolák, szakiskolák, } \\
\text { háztartási iskolák }\end{array}$ & 41 & 100,0 & 0 & 0,0 & 41 \\
\hline Összesen & 16340 & 73,4 & 5918 & 26,6 & 22258 \\
\hline
\end{tabular}

\footnotetext{
${ }^{3}$ A kimutatás nem teljes, ugyanis nem tartalmazza a mezőgazdasági iskolák adatait, valamint a magántanulók és felnőttképző tanfolyamok diákjainak számát!

${ }^{4} \mathrm{~A}$ kimutatás nem teljes, ugyanis nem tartalmazza a mezőgazdasági iskolák adatait, valamint a magántanulók és felnőttképző tanfolyamok diákjainak számát!
} 
REZUMAT

\section{SISTEMUL INSTITUȚIONAL EDUCAȚIONAL ŞI ŞCOLĂRIMEA DIN TRANSILVANIA ÎNTRE 1918-1948}

Cartea de față este rezultatul unei lungi şi ample cercetări. Este vorba de fapt despre o publicație statistică care prezintă şi analizează toate nivelurile de educație (de la grădinițe la educația universitară) îmbinând mai multe metode de lucru. Prima parte oferă o detaliată prezentare a legislației educaționale româneşti de după 1918, precum şi a politicii educaționale câteodată discriminatorie față de minoritățile naționale. Partea a doua a lucrării conține statisticile nivelurilor de educație şi analiza datelor.

În ceea ce priveşte cadrele legislative ale educației din perioada 1918-1948 se poate afirma că legiuitorul român şi-a urmat în primul rând interesele naționale statale române şi a încercat să impună criteriile de formare ale elitei națiunii dominante de multe ori în dauna minorităților naționale. Odată cu schimbarea de imperiu, adică de la unirea Transilvaniei cu România, statul român a preluat toate instituțiile educaționale maghiare de stat. Astfel, o mare parte a elevilor de etnie maghiară din Transilvania au părăsit sistemul instituțional statal şi a continuat studiile în şcolile susținute de către bisericile minoritare.

În teritoriile fostului Imperiu Austro-ungar alipite României, în principal Transilvania, Banat, Crişana şi Maramureş, au fost înființate şcoli de stat într-un număr mai mare decât în celelalte zone ale țării. Acest proces a fost realizat ori prin etatizarea şcolilor de stat maghiare ori prin înființarea de noi instituții.

Românizarea învățământului de stat a urmărit două scopuri: în primul rând, prin românizarea şcolilor, statul român a vrut să sprijine formarea unei elite românești în Transilvania şi să întărească poziția elitei intelectuale româneşti față de cea maghiară, evreiască şi germană. În al doilea rând, această românizare şi etatizare s-a datorat unei logici statale total diferite față de cea ungară de dinainte de 1918. În Transilvania de dinainte de război, conform practicii maghiare, majoritatea instituțiilor educaționale au fost susținute de către biserici, în schimb, în Regatul României situația a fost exact inversă. Aici, rolul asumat de către biserica ortodoxă în educație a fost aproape nesemnificativ, statul fiind aceea care a susținut instituțiile educaționale. Deci, demersul Statului român de a etatiza instituțiile de educație din fostele teritorii maghiare poate fi privit şi ca o încercare de unificare a sistemului. În urma acestui proces în mai puțin de zece ani s-a schimbat total tabloul sistemului instituțional. În anul şcolar 1920/1921 doar o treime din şcolile 
elementare a fost de stat, pentru ca, pe la sfârşitul deceniului, această proporție să depășească două treimi. O schimbare aproape atât de radicală poate fi surprinsă şi în cazul şcolilor de grad secundar.

Analizând repartizarea elevilor între sectorul statal şi particular/bisericesc se poate observa diferențe semnificative. Elevii de etnie română au studiat în $99 \%$ în şcoli statale. $\mathrm{Nu}$ aşa s-a întâmplat însă în cazul minorităților, acestea având un sistem instituţional propriu mult mai dezvoltat datorat şi circumstanțelor amintite mai sus. Dintre copii etnicilor germani doar $37,8 \%$ au studiat în şcolile statului. Acest procent a fost 54 la maghiari, iar la evrei 73,4.

Lucrarea de față este o analiză statistică complexă asupra situației educației din Transilvania, o analiză care lipsea cu totalitate din literatura istorică şi sociologică de specialitate până acum. Este o cercetare-bază care încearcă să fie punctul de pornire a cercetărilor privind istoria educației, sociologia educației, dar şi a istoriei minorității maghiare, germane şi evreieşti din Transilvania. 
ABSTRACT

\section{EDUCATIONAL INSTITUTIONS AND SCHOOL- AGE POPULATION IN TRANSYLVANIA BETWEEN 1919 AND 1948}

Our analysis presents the changes in the Transylvanian educational institutions and in the number of their students, according to levels of education, school types and the maintainers of the schools. The available statistics are incomplete and this did not allow us to make an exhaustive and complete presentation of the development of public education in the region. Nevertheless, we can more or less reconstruct the main characteristics of the education market and of the institutions of the educational system between 1918 and 1948 based on the data presented in our paper.

On the territories annexed to Romania after World War I, and especially in the parts gained from Hungary, state schools were established in a higher rate than the national average, either through the nationalisation of institutions of Hungarian language or through the construction of new schools. The large-scale developments in infrastructure had two reasons. The first reason was to consolidate the position of the Romanian population living in the newly acquired territories as opposed to Hungarians and Germans and to the denominational schools run by minorities. The other reason was the changed role of the state in the public education. Prior to 1918 in Transylvania, in line with the practice of Hungary, educational institutions were primarily maintained by denominations, while in Romania the role of the denominations was insignificant in this respect. Thus, the Romanian state basically aimed at implementing its existing school policy also on the newly acquired territories. All these resulted in the fact that while in the 1920/1921 school year only $32.7 \%$ of the primary schools were functioning in Transylvania were maintained by the state or by the communities, by $1928 / 1929$ this proportion jumped to $77.8 \%$. This switch in proportion can also be observed in case of lyceums and upper girls' schools, although to a smaller degree.

The data on Romanian students already indicate the effects of school policy of the Romanian Government. Prior to 1918 in Romania - thanks to the reforms of public education minister Spiru Haret -heavy emphasis was placed on practical education. This approach made its way to Transylvania, and resulted in the increased proportion of Romanian students in trade, vocational and housekeeping schools which exceeded by far the proportion of the minorities. Further factors also contributed to this: vocational schools were maintained by the state and the 
language of instruction in these schools was Romanian. The fact that these types of institutions were accessible for the Romanian population living mainly in rural areas is not incidental either.

The proportion of Romanian students was dominant also in teacher training schools, which ensured the supply of pedagogues who were meant to fulfill the need for teachers of the expanded primary school system. Commercial schools and lyceums were also maintained primarily by the state, and this was also visible in the proportion of Romanian students. Consequently, these institutions not only ensured the closing-up of the educational gap between the Romanian population and the minorities but also established the basis of the ethnic elite change (Romanians were employed in state offices, cultural apparatus, and as professional intelligentsia).

Higher education essentially mirrored the situation of secondary schools. In the case of Romanians and Jews we can again observe the overschooling, with the notable difference that in the case of Jewish students there was a decreasing tendency while in the case of Romanian students there was a continuous increase. In the period between the two world wars the supply for new generations of intelligentsia for the minorities slowed down and did not meet the societal demands. On the other hand, the number of Romanian graduates increased as a result of the "Romanianisation" of secondary schools with Matura and increased the number of students enrolled in universities.

The evolution of the Transylvanian educational system and that of the educational market were defined all along by the state policies (the elite formation strategies and the ethnic policies). 
Az erdélyi oktatási rendszer 1918 után gyökeresen átalakult. Az állami iskolákat románosították, az iskolák jelentős részében megváltozott a tanitási nyelv, és a kisebbségi egyházakra fontos feladat hárult az anyanyelvủ oktatás megszerrvezése terén. Az 1940-es második bécsi döntés, majd Észak-Erdély ismételt román fennhatóság alá kerülése állandó kihivások elé állította az erdélyi oktatásügyet. Harminc év tanügyi jogalkotását és statisztikai adatait összesíti ez a könyv, amely alapján részletes betekintést nyerhetünk az 1918 és 1948 között müködő alsó, közép- és felső fokú tanintézmények számának alakulásába, a diákok etnikai, felekezeti összetételébe, valamint az állami oktatáspolitikákelitreprodukciós logikájába.

ISBN 978-606-8178-75-2

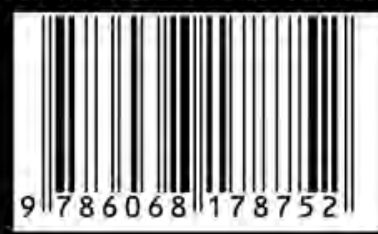

